\title{
Environment, Development and Change in Rural Asia-Pacific
}

Environment, Development and Change in Rural Asia-Pacific examines the economic, political, social and environmental challenges facing rural communities in the AsiaPacific region, as global issues intersect with local contexts. Such challenges, from climatic change and volcanic eruption to population growth and violent civil unrest, have stimulated local resilience amongst communities and led to evolving regional institutions and environment management practices, changing social relationships and producing new forms of stratification.

Bringing together case studies from across mainland Southeast Asia and the Island Pacific, an expert team of international contributors reveal how communities at the periphery seek to take charge of their lives, champion the virtues of their own local systems of production and consumption, and engage in the complexities of new structures of development that demand a response to the vacillations of global politics, economy and society. Inherent in this is the recognition that 'development' as we have come to know it is far from over. Each chapter emphasises the growing recognition that ecological and environmental issues are key to any understanding and analysis of structures of sustainable development.

Providing diverse multidisciplinary theoretical and empirical perspectives, this authoritative and stimulating book makes an important contribution to the revitalisation of development studies and as such will be essential reading for scholars in the field, as well as those with an interest in Asia-Pacific studies, economic geography and political economy.

John Connell is Professor of Geography at the School of Geosciences, University of Sydney, Australia.

Eric Waddell is Professor of Geography at Laval University, Canada. 


\section{Routledge Pacific Rim Geographies}

Series editors: John Connell, Lily Kong and John Lea

\section{Landscapes of Globalization}

Human geographies of economic change in the Philippines

Philip Kelly

\section{Sex Work in Southeast Asia}

The place of desire in a time of AIDS

Lisa Law

3. Urbanisation in the Island Pacific

Towards sustainable development

fohn Connell and Fohn Lea

4. Malaysia, Modernity and the Multimedia Super Gorridor A critical geography of intelligent landscapes

Tim Bunnell

\section{Made in the Philippines}

Gendered discourses and the making of migrants

James A. Tyner

6. Environment, Development and Change in Rural Asia-Pacific

Between local and global

Edited by Fohn Connell and Eric Waddell 


\title{
Environment, Development and Change in Rural Asia-Pacific \\ Between local and global
}

\author{
Edited by \\ John Connell and Eric Waddell
}


First published 2007 by Routledge

Published 2017 by Routledge

2 Park Square, Milton Park, Abingdon, Oxon OX14 4RN

711 Third Avenue, New York, NY 10017, USA

Routledge is an imprint of the Taylor $\mathbb{E}$ Francis Group, an informa business

Copyright (C) 2007 Editorial selection, (C) John Connell and Eric Waddell, (C) the contributors

Typeset in Baskerville by

Book Now Ltd

The Open Access version of this book, available at www.tandfebooks.com, has been made available under a Creative Commons Attribution-Non Commercial-No Derivatives 4.0 license.

British Library Cataloguing in Publication Data

A catalogue record for this book is available from the British Library

Library of Congress Cataloging in Publication Data

Environment, development and change in rural Asia-Pacific: between local and global / edited byJohn Connell and Eric Waddell.

p. cm. - (Routledge Pacific Rim geographies; 6)

Includes bibliographical references and index.

1. Sustainable development-East Asia. 2. East Asia-Economic conditions-21st century. 3. East Asia-Rural conditions.

I. Connell, John, 1946- II. Waddell, Eric. III. Series.

HC460.5.Z9E544 2006

$338.95-\mathrm{dc} 22$

2006015970

ISBN13: 978-0-415-40414-3 (hbk) 


\section{For Harold Brookfield}

This collection is directly inspired by and dedicated to the scholarship of Harold Brookfield, a man who never ceased to walk the fields and forests of the tropical realm and listen attentively to the words of its small farmers. 



\section{Contents}

List of illustrations $\quad$ ix

List of contributors $\quad$ xi

Acknowledgements xiii

1 Between global and local: the contest for development 1 ERIC WADDELL AND JOHN GONNELL

2 Volcanic eruption as metaphor of social integration: a political ecological study of Mount Merapi, Central Java MICHAEL R. DOVE

3 Pacific island rural development: challenges and prospects in Kiribati

FRANK R. THOMAS AND KAUTOA TONGANIBEIA

4 Agricultural landscapes of Kadavu: persistence and change on the Fijian periphery

ROBERT KUHLKEN

5 Tree crops and the cultivated landscapes of the southwest Pacific

JEAN KENNEDY AND WILLIAM GLARKE

6 Land reform and the state in Vietnam's northwestern mountains

THOMAS SIKOR

7 Seeds of discontent: oil palm and the changing production strategies among smallholders in Papua New Guinea 
viii Contents

8 Holding on to modernity? Siwai, Bougainville, Papua New Guinea

JOHN GONNELL

9 Oil palm expansion in Sarawak: lessons learned by a latecomer?

NIELS FOLD AND TINA SVAN HANSEN

10 Can Indonesia's complex agroforests survive globalisation and decentralisation? Sanggau District, West Kalimantan

LESLEY POTTER AND SIMON BADGOCK

11 Seeing 'water blindness': water control in agricultural intensification and environmental change in the Mekong Delta, Vietnam

FIONA MILLER

12 Rethinking watershed science: lessons from Thailand

TIM FORSYTH

13 Givil society and interdependencies: towards a regional political ecology of Mekong development

PHILIP HIRSCH

Index 


\section{Illustrations}

\section{Figures}

2.1 Location of Mount Merapi within Indonesia 18

2.2 Mount Merapi,Java 19

2.3 Villagers gathering grasses on the high slopes of Mount Merapi,Java 21

3.1 Kiribati 40

3.2 Drying fish, South Tarawa 45

4.1 Kadavu, Fiji 58

4.2 Yaqona garden on the slopes of Nabukelevu volcano, Kadavu 63

4.3 Raised fields (vuevue) with interplanting at Ravitaki, Kadavu 67

4.4 Village-owned taro terraces at Ravitaki 68

4.5 Terraced taro garden at Solodamu, Kadavu 69

6.1 Chieng Dong in northwestern Vietnam 93

6.2 Son La's model for agriculture and forestry, Vietnam 97

7.1 Papua New Guinea 109

7.2 Company oil palm harvest pickup, West New Britain 113

7.3 Woman's oil palm 'lus frut' harvest, West New Britain 114

7.4 Fresh oil palm fruit bunch harvest, West New Britain 115

8.1 Siwai, Bougainville, Papua New Guinea 128

8.2 Large cocoa fermentaries, such as this one at Hukuha (1975), used enormous amounts of high quality timber 135

8.3 Mounding in a sweet potato garden, Siroi (2001) 139

8.4 Vanilla drying on an appropriated AusAID signboard, Siroi (2001) $\quad 140$

9.1 Total land area under oil palm, Malaysia 150

9.2 Land areas under oil palm and rice production, Malaysia 153

9.3 Sarawak 155

9.4 Land use in Niah catchment area, Sarawak 158

9.5 Actual and projected areas of oil palm plantation in Niah
catchment area, 2002

10.1 Sanggau District, Kalimantan, Indonesia 171

11.1 Irrigated rice area, Vietnam and the Mekong Delta, 1980-94 198

11.2 Land use in the Mekong Delta 200

11.3 Winter-spring crop areas, 1985-98 201 
11.4 Planned water resource development in the Mekong Delta 202

$\begin{array}{lll}12.1 \text { Northern Thailand } & 215\end{array}$

12.2 Yao woman farmer on steep, cultivated slopes, northern Thailand 218

12.3 Pha Dua village agriculture, northern Thailand 218

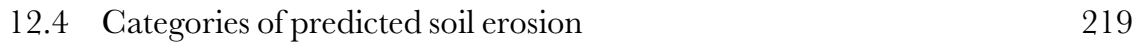

$\begin{array}{ll}12.5 \text { Categories of slope steepness } & 220\end{array}$

13.1 Mekong Basin and Region 228

13.2 Greater Mekong Subregion infrastructure 235

13.3 Se San Basin, Cambodia 242

\section{Tables}

3.1 Crops planted by 20 households, South Tarawa 44

4.1 Cultivars of main food crops grown in Nabukulevu District, western Kadavu $\quad 65$

5.1 Tree crops commonly eaten in Papua New Guinea 82

7.1 Mean number of persons per LSS block, Hoskins, 1972-2000 112

7.2 Percentages of LSS blocks employing different harvesting strategies at Hoskins, Bialla and Popondetta 116

7.3 Mean population per LSS block by harvesting strategy at Bialla and Hoskins

7.4 Mean numbers of households per LSS block by harvesting strategy at Bialla and Hoskins

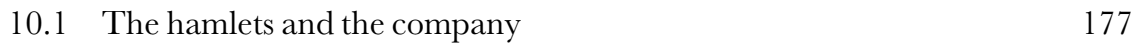

11.1 Summary of water and agricultural transformations in the Mekong Delta

11.2 Changes in land use in the Mekong Delta, 1990-2000 200

12.1 'Mother statements' about watershed degradation and suggested amendments

12.2 Areas of historic cold-dry season land uses in the Chiang Rai mountain village 


\section{Contributors}

Simon Badcock Independent Consultant, Bali, Indonesia

William Clarke Resource Management in Asia-Pacific Program, Research School of Pacific and Asian Studies, Australian National University, Canberra

John Connell School of Geosciences, University of Sydney

George N. Gurry Department of Social Sciences, Curtin University of Technology, Perth

Michael R. Dove Department of Anthropology, and School of Forestry and Environmental Studies, Yale University

Niels Fold Institute of Geography, University of Copenhagen

Tim Forsyth Development Studies Institute, London School of Economics

Tina Svan Hansen Institute of Geography, University of Copenhagen

Philip Hirsch School of Geosciences, University of Sydney

Jean Kennedy Division of Archaeology and Natural History, Research School of Pacific and Asian Studies, Australian National University, Canberra

Gina Koczberski Department of Social Sciences, Curtin University of Technology, Perth

Robert Kuhlken Department of Geography and Land Studies, Central Washington University, Ellensburg

Fiona Miller Risk and Vulnerability Programme, Stockholm Environment Institute

Lesley Potter Department of Human Geography, Research School of Pacific and Asian Studies, Australian National University, Canberra

Thomas Sikor Institute for Agricultural Economics and Social Sciences, Humboldt University, Berlin

Frank R. Thomas Historic Preservation Office, Majuro, Marshall Islands 
xii Contributors

Kautoa Tonganibeia Environment and Conservation Division, Ministry of Environment and Social Development, Kiribati

Eric Waddell Département de géographie, Université Laval, Quebec 


\section{Acknowledgements}

We are particularly grateful, of course, to the various contributors from several different countries, who met ever-fluctuating deadlines. They, like us, are more than grateful to a much larger number of people scattered throughout the rural and urban areas of Asia and the Pacific who were the most crucial parts of this work. We are also extremely grateful to an anonymous reader of the whole manuscript who found errors in many of our ways, though the usual disclaimers apply. Without the computer skills of Rowena Butland we would never have managed to produce maps that were either valuable in themselves or stylistically comparable, and without Anna Warr's last-minute (actually many hours) exertions technology would have defeated our efforts to sort out the final manuscript. We have been fortunate to have the support of Routledge throughout this enterprise and particularly to Stephanie Rogers who had faith in the project and Helen Baker who saw it through to the end.

With affection we have dedicated the book to Harold Brookfield, a doyen of studies of changing rural scenes in Asia and the Pacific, and whose work informs every single chapter of this book. His pioneering and ongoing work at the grass, rice and taro roots, for over half a century, has been an inspiration far beyond the confines of this slim volume. 



\title{
1 Between global and local The contest for development
}

\author{
Eric Waddell and John Connell
}

\begin{abstract}
The growing demands for natural capital are making ecological scarcity an ever more volatile trigger for human conflict. Like ancient societies before it, the modern world has lost the capacity to control its interactions with the natural environment. Nation states have either outgrown or despoiled local resources and all are now reaching out to more distant sources of natural capital.
\end{abstract}

(Woodbridge 2004)

The many arenas of development are vigorously contested these days, as indeed are the very philosophy and practice of development as a whole. 'Development' has become a somewhat tired word, the memory of the circumstances surrounding its birth having largely faded into the mists of time. The urge for rapid economic and social development for all was born out of the ashes of the Second World War and driven by, variously, the need for European reconstruction, an alternative economic model to that of the communist bloc and the urgency of thwarting the rapidly accelerating demands for independence in the colonies. By the 1990s, in a resolutely post-war, post-communist and post-colonial world, and in a period of accelerated globalization, the traditional development agenda, in the form of aid and integrated regional development planning, generated relatively little interest, at least among those nations and corporate interests that are the driving force behind such international bodies as the World Trade Organization, the World Bank, the United Nations Security Council and the G8. The global decline in publicly funded development assistance is an unequivocal expression of this change in direction, as are the deteriorating social and economic circumstances in many poorer countries and the increasing numbers of economic and environmental refugees who seek simply to migrate in an effort to improve the material conditions of their lives. Certainly there is a continuing concern with a range of issues that occupy the moral high ground, notably poverty reduction, gender equity, participation and good governance, but they are somewhat ill-defined objectives, clouded in good intentions but selectively or inadequately applied. The inevitable mix of economic determinism, applied in its most extreme, neo-liberal form to developing countries (Simon 2003: 6), and of realpolitik mean that such concerns remain minor considerations compared with an overriding commitment to unrestrained 
economic growth across a world that must know no boundaries to the movement of goods, services and capital (if not of people).

The wealthiest nation states have, for the most part, long outgrown their immediate resource bases, and they must now reach far beyond their boundaries in a relentless search for continued growth. New international institutions and private transnational corporations have become key actors in this quest, often setting the agendas and undermining the authority of the state. Unconstrained production and consumption of the world's natural capital have become an overriding, seemingly universal preoccupation, if not, indeed, an unquestioned faith, the promotion of which, it is widely (but diffidently) affirmed, will ensure more effective wealthsharing and provide all the peoples of the world with a common future, as a natural and spontaneous outcome of the new agenda. It is almost as if the dominant discourse has turned full circle, and an updated version of Rostow's The Stages of Economic Growth has re-established its authority (Rostow 1991). Indeed, his linear and remarkably simplistic view of development, first published in 1960 was, not surprisingly, re-edited in 1991, in the aftermath of the collapse of the communist bloc, and thereby acquired a new lease of life. However, at the same time, a new generation of scholars proposed a radically different interpretation of this new world order, affirming that it is not wealth but poverty which is being globalized (Chossudovsky 2003) and that we are entering a new era of global disorder (Ramonet 1997). Recent editions of the United Nations Development Programme's Human Development Reports tend to confirm this disturbing thesis, as do World Bank findings that African per capita wealth has fallen below the levels of the late 1960s. New and more subtle Millennium Development Goals merely emphasize these trends. Disparities within as much as between nations have also increased. The profound contradictions of development discourse and practice are there for all to see.

Whatever vocabulary is in fashion - from dependence and deprivation to exclusion and empowerment - and despite what Baker a quarter of a century ago called the 'passing parade of paradigms' (1979: 167), the lot of the great mass of people, especially in more remote places, has only slowly improved in the past half century. Moreover, such improvements (for example, in literacy and life expectancy) are sometimes masked by feelings of relative deprivation. Thus, while in the years before 1997 a select group of countries in Southeast and East Asia 'experienced perhaps the most rapid and sustained period of economic growth in human history', this was paralleled by 'environmental degradation on an unprecedented scale, growing inequalities between the so-called haves and have-nots, rampant corruption, social malaise and a widening gap between the prosperous core and a lagging periphery' (Rigg 2002: 137). While any definition of development will always be contested, and was revisited especially in the wake of the Asian crisis (Rigg 2002; Simon 2003), local circumstances are subsumed in the growing interdependence of states, regions, social groups and institutions (Brookfield 1975), and such interdependence poses serious problems for policy formation and planning.

Indeed, as Bebbington (1999: 3) has phrased it, 'There is an awful mismatch between the ability to develop frameworks for understanding rural poverty, and the ability to have any significant impact on that same poverty'. It is a mismatch that 
both points to the divergence between policymakers and scholars and echoes the observations Richard Jolly (who ushered in the concept of redistribution with growth) of over a quarter of a century ago that the policy prescriptions of many scholars are simply too 'idealistic' - in their opposition to powerful vested interests - or too 'long-term' to stand any chance of success (Jolly 1975). The world moves on too quickly and narrowly.

Inherent in Rostow's work was the need for all that is subsumed within the term modernity - improved infrastructures, economic diversification with a particular focus on industrial development and democratic institutions. These themes remain prominent in contemporary development strategies. All point to varying degrees of rupture with the past and imply a hierarchical ordering, and valuation, of cultures and economies. The uncomfortable rise of postmodernism and post-development, with their comprehensive yet totally intellectual assaults on the foundations of modernism, has largely failed to shake off the perceived virtues of modernity, whether in villages or, more obviously, corporate boardrooms or international institutions.

Yet modernity is a condition where people are exposed to a bewildering range of new ideologies, lifestyles and goods - such as a new middle class, increasingly divorced from the needs and values of rural people, emerging across the AsiaPacific region. Western ideologies are centred on individual autonomy and achievement, and are backed by power, money and privilege. The promotion of individual interests as distinct from the collective good is actively promoted through formal education, the media and popular culture, to name only a few of the agents in the inevitable shift in values that accompanies the development agenda and process. Models of those who have 'succeeded' are proposed, carrying with them ideologies that push individual autonomy and achievement while at the same time sometimes also simultaneously celebrating the 'virtues of quaint, pre-modern, communal cultures' (Brison 2003: 337; Connell 2007). Global images and ideologies pervade local development strategies.

Since globalization has replaced development as the key concept on the international agenda, regional differences and regional interests have taken on a radically different configuration. While vigorously defended at the local level - as a vital means of managing relations with the larger world - at the global level they are simply considered to be barriers to trade. Any form of protectionism - be it environmental, cultural or economic - is judged to be an anathema, inhibiting the search for both material resources and markets. As the authority of the state is progressively undermined and its sphere of action reduced, so the great geographical regions of school textbooks lose much of their meaning. Boundaries are blurred: resource regions, which frequently sit astride national boundaries, now drive political and economic agendas, while supply lines (shipping lanes, pipelines, etc.), which form links and networks rather than frontiers, become primary preoccupations. Nations and continents - essentially static realities - fade into relative insignificance in contrast to a much more dynamic and volatile world, which is now conceived in terms of geopolitics, geo-economics and geo-strategies - and an uncompromising capitalist agenda. Contemporary transitions in development 
have moved from perspectives that emphasized production in nation states to the emergence of circulation-based capitalism and a new 'set of social imaginaries that privileges a global totality as it produces new forms of risk that may destroy it' (Lee and LiPuma 2002: 211 ). Technology has shifted the world towards a global village, but in so doing has re-focused attention on regions, villages and localities as they intersect in a multitude of ways with global trends and pressures.

Although the environment figures highly on many twenty-first century international agendas, the focus of attention is remarkably selective. The dominant concerns are global: global warming, rising sea levels, El Niño, depletion of the ozone layer and melting ice caps. Regional expressions of climate change - the increasing frequency of cyclones in the Caribbean, coral bleaching in the Pacific, deforestation in Southeast Asia, and even torrential rains in Europe - tend to be viewed as random perturbations that may well have tragic consequences but are of passing, idiosyncratic importance. It is not that science is as yet simply incapable of measuring local and regional change, despite the uncertainties, but rather that the principal institutions addressing the question of global change are themselves global in nature.

In one form or another, the 'environment' - whether in part, as depletion of resources, loss of biodiversity or a rise in pollution, or in whole - has become almost inescapable in development discourse. In the past decade or so there has been one major shift in the environment and development agenda: the term '(environmentally) sustainable development' has replaced 'economic development'. Whether the shift is simply a semantic one (as was the rather earlier push for 'decentralization' or 'participation') or whether it involves a radical change in temporal parameters, strategies and goals remains to be seen, but it is one that concerns many of the authors in this book. Certainly, for many people, the expression 'sustainable development' is an oxymoron, the noun evoking (unlimited) growth and the adjective the concept of steady state, while according to Serge Latouche it is simply 'the latest ideological gadget of the West' (1994: 77). While such terms have become common currency, infrastructure development and related neoliberal economic frameworks continue to move rapidly, despite the still very limited understanding of their impacts on local ecosystems and livelihoods.

Not surprisingly, approaches to environment and development that are increasingly conceived, implemented and managed globally are frequently challenged at the level of local communities, whose very way of life is characterized by an active engagement in the processes of production. The fact that the scale of resource exploitation initiatives is increasing only accentuates the drama. The impacts are not simply spatial - mega opencast mines, plantations, fishing and logging initiatives - they are also unequivocally temporal. As one economist pronounced (with tears in his eyes) of the people of Bougainville, who had been ravaged by a massive opencast copper mine and an ensuing civil war, 'They have been condemned for geological time'. ' The earth's envelope is seriously damaged in a rapidly increasing number of places, and the human societies that depend on it for their very survival are struggling. Voracious demands for resources, despoiled environments and shattered human communities constitute a volatile mix of ingredients that lead, 
almost inevitably, to conflicts over resources, which often take on ethnic dimensions. Development, in its present form, ironically serves all too frequently to further marginalize those small, largely locally organized rural communities who still constitute, at the beginning of the twenty-first century, the majority of the world's population. Specifically, it undermines any local decision-making capacity, while at the same time it undermines the decision-making capacity of entire nation states.

Most academic scholarship reinforces this top-down order, condemned as it is to observing farmers, integrating their observations into theoretical constructs and then reporting back to the international scientific community. Scientific researchers rarely collaborate with farmers in a manner in which communication is horizontally rather than vertically ordered. In other words, the former, as a further manifestation of the global order, rarely become allies of the latter, despite a context where local agrarian communities are at once bearers of knowledge, constant innovators in response to the inroads of globalization and real people committed to surviving - and ideally succeeding - in a rapidly changing world. As long ago as 1973, Harold Brookfield made a vigorous plea in favour of 'new spatial structures of enquiry':

we have made little contribution of direct significance for the people among whom we have worked, and our efforts to achieve relevance have at best been partial, because our base is so firmly overseas. In consequence of remaining geographers, we have imported external models into our thinking the moment we have left the field, and begun the task of relating our work to the growing core of our subject. We have remained foreigners in thought, and our ambivalence between discipline and area has not been resolved.

(Brookfield 1973: 93)

Brookfield's most recent publications, some thirty years on, highlight what he has learned from a lifetime of engagement with agrarian societies and small farmers. His Exploring Agrodiversity is a celebration of 'human inventiveness and adaptability' (Brookfield 2001: 285) in response to global political, economic and environmental change. The phrase 'farmers and other scientists', used as a subtitle in the epilogue to Exploring Agrodiversity, resonates like a dedication and, in choosing it to close the book Brookfield stresses that discourse and practice have merged into a single scholarly act. Such themes are crucial in the Asia-Pacific region.

\section{The Asia-Pacific region}

The Asia-Pacific region, notably Southeast Asia and the Island Pacific, is one of the principal actors in this unfolding drama, having in the latter part of the twentieth century become one of the world's most important arenas of rapid change and growth. Its rise to the status of a core global region in recent decades is to be explained in large part by the juxtaposition of two mutually distinct and exclusive regional products of the Western imagination: first, the densely settled and culturally 
complex and powerful Far East; and second, the largely empty, culturally exotic but powerless 'last unknown', which was only decolonized in the 1970s and 1980s. The two have since acquired complementary roles that thrive on their geographical proximity. Interwoven throughout mainland and insular Southeast Asia, the islands of the western Pacific and the intervening oceans are a wealth of primary resource regions, replete with minerals, timber and fish, as well as land for the establishment of commercial plantations. Adjacent to these, in the Asian part, are massive and densely settled urban populations actively engaged in the processes of resource transformation for global and, increasingly, local markets. The converging interests and overlapping destinies of the two regions - one based on resources and the other on capital, processing and markets - is one of the dominant features of the early twenty-first century, where 'economic tigers', massive transnational regional integration projects, the world's largest tuna and tropical timber stocks, the largest opencast mines and newly established mega-plantations are all located in close proximity to each other.

Several countries have experienced rapid economic growth in recent years while others have faced economic decline, in some part stemming from the 1997 Asian financial crisis, which resulted in some questioning of economic orthodoxies. In parts of the Pacific and in the more isolated Asian regions, relatively little has changed in decades (Blaikie et al. 2002). Other parts, however, have experienced radical transformations. Yet while each country and region has experienced change differently, all have been linked into wider processes of globalization, and the impacts of varied modernities and capitalisms. Accompanying economic change, such as commodification, shifts towards free trade (but also regional trading blocs) and new structures of access to social services, has been environmental change, from climatic shifts and volcanic eruptions to accelerated deforestation and population growth and movement. Some constellations of change have strengthened state power, leading to constraints on local people's livelihoods, while elsewhere weakened state power has led to greater local autonomy, but also more threat from outside, especially in the form of poorly controlled resource exploitation in weak and compliant states. Such processes of development and disruption have led to growing concern over the use and sustainability of local resources, whether coral reefs, mahogany groves or copper deposits. As the various chapters in this book discuss, local peoples (whether indigenous or migrant) have comprehended and coped with these changes in various ways, however limited their choices may have been.

It is no longer conceivable that Asia and the Island Pacific be treated as separate worlds, almost totally isolated one from the other. More important, given the late and tangential entry of the Island Pacific and significant parts of island and upland Southeast Asia into the contemporary world system, and the fact that the bulk of the world's manufactured goods are now produced in Asia, there are here intense and constant interactions between global, regional and local forces. Here too the concerns, the interests and the strategies of local communities are readily revealed. If the ultimate goal of development is to improve the well-being of all the world's populations and of the natural environment that sustains them, for all generations 
to come, it can be reasonably assumed that small communities engaged in primary production in rural areas, historically grounded in their local realities, have a great deal to contribute in terms of knowledge and experience to the ongoing global environment and development debates. Social scientists, notably geographers and anthropologists, have for decades observed such communities, describing in great detail their economic and environmental practices, their values and their collective and individual aspirations. They have provided valuable critical assessments of their lives, highlighting the remarkable intelligence and sophistication of so many subsistence and peasant systems of production that creatively accommodate material needs, environmental constraints and culturally defined aspirations. Many such studies, at least in the early post-Second World War decades, contributed to environment and development debates. However, as the scales of development projects increased, the rates of growth accelerated and alternative economic models collapsed, their perspective has tended to be disregarded. An impatient growth agenda has silenced the voices of the peasantry and, far too often, the writings of those scholars who have served as intermediaries between local experiences and universal knowledge.

If one voice has prevailed within and, increasingly, beyond the Asia-Pacific region, it is that of Harold Brookfield. For half a century he has concentrated his intellectual energies on rural environment and development issues, conceived in terms of the dynamic relations between people and land and adopting an approach that is firmly grounded in 'micro-geographies' (local study), hence in fieldwork. That approach is grounded in the knowledge possessed by those people who derive their daily sustenance from productive activities: the small farmers of the region. It stresses the value of local empirical knowledge as opposed to unsophisticated and ungrounded scientific or universal generalizations. A geographer by training and by affiliation for most of his career, Brookfield has never felt a particular need to call himself anything, thereby no doubt adroitly avoiding the label of 'expert'. So tenacious has he been in his resistance to the dictates of individual disciplines, of largely ephemeral intellectual movements and of the often-times politically imposed agendas of national research funding agencies, that he successfully moved, through time, from strictly local enquiry - in the New Guinea highlands in the 1960s - to more broadly based regional investigations - with the UNESCOfunded Man and the Biosphere Programme project in the islands of Eastern Fiji in the 1970s and 1980s - to circum-tropical studies - with his United Nations University-funded project on People, Land Management and Environmental Change (PLEC) from the 1990s on. The last initiative made it possible for him to create a situation in which peasant farmers and academic researchers could share their knowledge and experience in a context of mutual respect, the one expert creatively nourishing the other: empowerment alongside the advancement of knowledge. This was a remarkable achievement given the structural problems associated with environment and development projects and programmes, where knowledge is invariably conceived at the top and strategies are imposed from the top down. Significantly, empirical study has constantly nourished, even determined, Brookfield's broader reflections on global environmental and developmental 
issues. Two works stand above the others in this respect, inspiring the vast majority of contributions in the present collection: Interdependent Development (Brookfield 1975) and Land Degradation and Society (Blaikie and Brookfield 1987). His most recent publications, Exploring Agrodiversity (Brookfield 2001) and Agrodiversity (Brookfield et al. 2003), will probably have a similar impact. It is for this combination of longevity, perspicacity, and a wisdom that underpins so much of what is discussed here that this book is dedicated to Harold Brookfield. He has chosen, throughout his career, to navigate on the periphery - a periphery that is both intellectual and geographical - to be attentive, to give a voice and to give credibility to those who live and work on the periphery (Connell and Rugendyke 2005). The contributors to this collection are heirs to that commitment and, in their research and their writings, are likewise concerned to give sense to the acts and authority to the many voices of the AsiaPacific region.

If Brookfield's work has influenced so much writing on the region it is not simply because he has moved through much of it - individually or in collaboration with others - as an unrepentant field researcher. More important is the fact that his writings typify those intellectual transitions that are clearly expressed in the present collection. Such transitions are motivated by an appreciation that relations between people and environment are essentially dynamic, in their concern to improve the quality of lives in the short term and to ensure the maintenance of human communities in the long term. In no sense are they driven by the much more ephemeral and dramatic preoccupations of agendas of unlimited economic growth and consumerism. Nor are they the prisoner of some heavy-handed imaginary reality called 'tradition', which more often than not evokes a blind conservatism and a naïve celebration of the past. For Brookfield, and those like him, all rural peoples are eager to adapt and change, to innovate. Indeed, they have no choice. However, they act according to their own needs and constraints, and their decisions are determined by accumulated experience and knowledge. Such an approach requires a powerful contextual understanding of the behaviour of rural communities, of their knowledge and of their actions, with respect to their social and natural environments, both larger and immediate.

\section{Re-enter ecology}

The foundations of a broad social science approach to environment and to development are vested in cultural ecology, a movement that flourished in Melanesia in the $1960 \mathrm{~s}$ and $1970 \mathrm{~s}^{2}$ and also, but to a lesser degree, in island and continental Southeast Asia. Cultural ecology meant focusing on the adaptive strategies of what were frequently described as 'closed corporate communities'. Such tightly bounded realities (characterized by some as 'human laboratories') enabled foreign researchers to focus on 'local voices', local knowledge, local empiricism and local practices. The strength of such an approach lay in the detailed knowledge of place and people that it generated, and in the shift in attention - hence in authority from the observer to the observed. It significantly increased the legitimacy and our understanding of the local, a few short years before 'the global' was to impose its 
presence. And therein lay the limitations of such an approach, for interactions across the boundaries of the local (eco)system rapidly surpassed in importance those within the system. Local communities were in the process of becoming rapidly disempowered, if not indeed dislocated and dismembered, before the very eyes of the researchers.

This new reality led, logically, to the emergence of political ecology in the 1980s and 1990s, operating from the premise that people, places and environments are never separate, isolated realities. The human and cultural ecology approach that focused on local systems, with an emphasis on equilibrium and the role of people as 'organisms', gave way to a political approach that emphasized wider structures of power, a more critical social science and an emphasis on change, conflict and inequality; where people were social actors. The more recent inclusion of agency within the broader context of human-nature interaction has enabled a better understanding of material struggles over natural resources and new perceptions of conflicting environmental imaginaries and contextual environmental histories (Nesbitt and Weiner 2001). Simultaneously, there has been a shift away from technical and scientific imperatives for environmental management towards issues of plural environmental truths, environmental justice and hybrid knowledge (Blaikie and Muldavin 2004). Political ecology again emphasized that nothing was exclusively local any more, if indeed it ever had been. Rather, local communities and areas are subject to regional and global forces, principally of an economic and political nature but also environmental, especially as resources such as water become scarcer. In almost every case, rural people are more involved in migration and non-agricultural production than ever before (for example Rigg 2001; Blaikie et al. 2002). Increasingly important cross-boundary linkages are, moreover, profoundly and increasingly unequal in nature. Typically, rural populations and communities are located at the periphery - geographical, economic and political of the state and of the global order, yet the scales and hierarchies are inherently unequal, and boundaries that were once impermeable are more obviously porous (Escobar 2001; Sturgeon 2004). A political ecology focus directs analysis, and action, to the manner in which particular issues, such as soil erosion, flooding or deforestation, are the result of a suite of processes all operating at different scales and with different underlying forces. It therefore brings together realistic assumptions about the power of human agency, the integration of biophysical processes and social relations, and the multidimensionality of outcomes at different times and places, highlighting three interrelated concepts of marginality: ecological, economic and political-economic (Batterbury 2001; Blaikie and Brookfield 1987; Cramb 1998).

Increased emphasis on ecology has paralleled renewed interest in the incorporation rather than exclusion of local knowledge, and hence also the greater incorporation of women in development processes. Such inclusion emphasises diversity. Yet, as Bill Clarke emphasized some years ago, what may be seen as 'progressing with the past' is inherently difficult given some local beliefs, such as, as in the case of one group in the highlands of New Guinea, though they 'live in a relatively stable ecosystem they are becoming so impressed by the artifacts of the 
outside world's plundering economy that they feel they can only learn from that world, that they have nothing to teach it in return' (Clarke 1971: 196). Yet it is also 'all too easy to romanticise these social arrangements that distinguish much of peasant society' (Scott 1976: 5) and fall into the trap of discovering a kind of virtuous society somehow aloof and independent from global forces.

The merging of political and cultural ecology in recent years has been motivated by another consideration: the growing demands for what Woodbridge (2004) has called 'natural capital' and the ecological scarcity that such demands produce. The enormous pressure on the earth's outer envelope produced by an economic system that has become global and which is increasingly unhampered in its actions, particularly at the periphery, has unleashed new destabilizing environmental forces on the multitude of small rural communities in the tropical world. Such communities are particularly sensitive to this multiplier effect, with their very survival depending on the successful long-term management of local ecosystems. It is here that the specific knowledge of peoples, often indigenous peoples with prolonged experience of specific places on the surface of the earth, acquires great importance, both for their own survival and for the education of the authorities - experts, managers and exploiters - who are committed to the economic transformation of their corner of the world.

\section{New directions?}

It is within this perspective that a more evidently cultural and political ecological approach to environment and development issues among rural populations in the Asia-Pacific region has become the focus of attention of a new generation of scholars. These scholars, like those that preceded them, are engaged in rigorous, empirical local studies, but the configuration and the context have changed. They are concerned to tell local stories and describe local experiences, preoccupations, challenges and dramas. In other words, they are concerned to read the world through local eyes, against a backdrop that is global. In so doing, they vigorously challenge the widespread assumption that rural populations are uninformed and require 'instruction'; indeed, several of the chapters in this book have emerged from participatory and collaborative research with villagers. Any such assumption is not only wrong, but also reinforces the marginalization, frustration and anger of populations that are so summarily condemned. They are displaced mentally as well as physically, and the cost is immeasurable. So, in adopting such a 'bottom up' approach, these scholars' intention is to challenge the meta-narratives, the global discourse and strategies of what was not long ago proclaimed the 'new world order'. In the final analysis, the vision that they propose is not one that is opposed to development or growth. Rather, it is one that directly challenges a single and universal model of such development, where everything is externally driven ideology, priorities, funding and projects. It challenges a certain kind of globalization, where the world is reduced to a single market and its inhabitants to human capital. It requires modes of analysis that develop more subtle understandings of political agency, incorporating economy and culture and also class and identity, in 
moving towards 'reflexive post-structural political economies' (Larner and Le Heron 2002). In so doing, it makes a plea for an altermondialization, another kind of globalization: one that is organized around a diversity of human communities who, while being concerned about improvements in individual material well-being, are also concerned about the collective good. While such good is certainly material, it is also social and spiritual, if not indeed moral, for it is concerned with matters of human dignity and respect.

In such perspectives, culture becomes not a threat to development but a core element in development (Curry 2003). Yet 'culture' can seem all too slippery and potentially conservative for those concerned with issues such as institutional design and fiscal transfers, and perhaps even for those with intellectual roots in variants of political economy (Bebbington et al. 2004: 188). At the same time, it is necessary to be wary of the mechanistic and simplistic ways in which culture can crudely be treated as a resource and as a store of knowledge, techniques and practices to be mobilized in pursuit of externally defined development goals (Radcliffe 2001), and of the structures of power that exist within local cultures, crude assumptions of the unparalleled virtues of the 'old order' (that often took little note of local social structure) and links between locality and identity that challenge wider notions of citizenship and belonging. Nonetheless, as various chapters in this book well demonstrate, social relationships are both key elements influencing the structures of development and change and critical components of participatory development. Indeed, the maintenance of social and cultural practices may be as important as income gains and poverty reduction for many local communities. Rural people are more likely to have holistic perceptions.

Necessarily, this book seeks to draw attention to questions of scale, focusing on local knowledge and practices, and their roles in the face of global change. In every case, development strategies are negotiated - and often fought out - between the local and global, and of course the national, however imprecise these categories may be. Here, the focus is primarily on 'the local [as] ... a site of struggles over cultural practice' (Bebbington et al. 2004: 189). Such struggles are readily evident in Southeast Asia, where, for example, dam projects have been contested in different ways, at different scales, and on social, economic and environmental grounds. Here and elsewhere there are 'daily, messy negotiations and conflicts between diverse social actors' that seek to shape better livelihoods (Radcliffe 2004: 518). Local theory alone - or what has been described as 'the lure of the local' (a remnant from the 'small is beautiful' era) - is not enough, since processes of appropriation are simultaneously local and global (Mitchell 2001: 278; Watts 2002). The lives of rural people cannot be comprehended only at the local or even the national scale, though it is gradually becoming evident that where policymakers have disengaged from top-down strategies of intrusive resource development and decentralization, communities are more likely to be seen as key actors in rural development, meaningful participation and conservation (Agrawal and Gibson 1999). In an age of unparalleled mobility, access of local communities to wider resources is more crucial than it has ever been.

Such is the focus of the present collection. Moving backwards and forwards from 
mainland Southeast Asia, through Indonesia, on to Melanesia and into remote islands of Micronesia, it investigates resource frontiers and reflects on the development experience at the margins. It considers the wealth and significance of traditional knowledge and of adaptive strategies directed to diversity maintenance, and the range of ways in which livelihoods may be constructed and reconstructed in a more or less sustainable manner (Smith and Wishnie 2000). It explores the goals, the aspirations and the tribulations of local communities, both indigenous and immigrant, investigates massive integrated development initiatives and highly focused resource economies, and seeks to understand how local societies meet difficult challenges to ensure their survival and development in the face of diverse social, economic, environmental and political challenges. It traces the manner in which local lives have espoused agro-diversity as the most efficient means of achieving sustainability, and how too often such local, complex systems have been replaced by something simpler but less sustainable. However, farmers have often been resilient and have challenged oppressive and inappropriate models, sometimes in the face of the discontents of modernity and disenchantment with the course of development, where commodification and individualism have been found wanting. Complex histories, the balances between structures, agencies and scales and the uncertainty of political and environmental contexts have shaped a multitude of responses (Scoones 1999; Purcell and Brown 2005). At the core there is a growing recognition that to ignore or devalue the role of local people would be 'to attack the cultural integrity and human agency of peripheral peoples' (Sahlins 1993: 13).

Several authors emphasize how there has been some new recognition of the merits of diversity and the need to bring together 'traditional' farmers with other proponents of rural development. Resource sovereignty and the meaning of the 'resource curse' are never far from the thoughts of the contributors and, of course, the actors. Scale and distance, hence degrees of incorporation in global systems, are key considerations. The originality of the approach lies in its challenging of what are now called meta-narratives: through the telling of local stories, local experiences, local preoccupations, local challenges and local dramas. Such diverse local stories all confirm that everyone is concerned to improve the quality of their lives, but not at any cost; ethics, material goals and social structures are constantly reshaped. Social considerations are as important as material ones. It is vital to consider local concerns, local knowledge and local experience. Empowerment is, indeed, a key word, as is dignity. The margins - and those that inhabit them - are not only of material importance to the centre of the modern world system, they are also of symbolic and moral significance, and they offer some of the solutions for ensuring the long-term viability of the biosphere. Collectively, these studies emphasize that meta-narratives are limited in their explanatory and practical value, but that local people, whose resource use and management practices play a key role in maintaining cultural identity, have at least some of the critical answers to the future of development. Equally, they emphasize the role and value of long-term studies, and repeated visits, at a time when what Robert Chambers long ago called the 'Friday-flash' syndrome has become all too common. Such is the message that 
pervades this diverse range of studies, emanating from a dozen points on the periphery of rural Asia-Pacific.

Some of the last words might be left to Harold Brookfield and his own conclusion of more than a quarter of a century ago:

The exploitation of natural resources cannot be said to have been retarded. The heritage of future generations (if any) is being wantonly sacrificed for short-term gain in a manner that recalls to mind the old and almost forgotten weight of criticism directed at farmers practising shifting cultivation. In denigrating the improvidence and lack of foresight of these supposedly primitive 'mangeurs de la forêt' it seems that we were in greater truth describing ourselves'.

(Brookfield 1975: 203)

The various chapters here reveal how communities at the periphery seek to take charge of their lives, champion the virtues of their own local systems of production and consumption, and engage in the complexities of new structures of development that demand response to the vacillations of global politics, economy and society. Inherent in all this, across a range of countries and contexts, lies the recognition that development as we have come to know it over the past half century is far from over. ${ }^{3}$ On the contrary, it is a diverse, multi-faceted and accelerating experience that is all too frequently marked by 'silent violence', ${ }^{4}$ increasingly contested in nature and, as such, ever open to new interpretations and encounters.

\section{Notes}

1 Roman Grynberg, former economic adviser to the Prime Minister of Papua New Guinea, speaking before a class of resource management and conservation students at the University of the South Pacific (Fiji), 1993.

2 One of the foremost American cultural geographers of that era, Marvin Mikesell, referred to it as 'The New Guinea syndrome'.

3 This is in spite of the ardant desire expressed by François Partant over two decades ago in his book La Fin du Développement: Naissance d'une Alternative? (Partant 1982) and by all those who shared his hopes and expectations. Partant, like Ernst Schumacher (the author of Small is Beautiful), had spent a significant part of his career in national and international financial institutions, and he was also a 'homme de terrain'.

4 Silent Violence is the title of a major study detailing the dramatic impact of colonial capitalism on the rural populations of northern Nigeria (Watts 1983).

\section{References}

Agrawal, A and Gibson, C (1999) Enchantment and Disenchantment: The Role of Community in Natural Resource Conservation, World Development, 27, 629-49.

Baker, R (1979) Review of M Lipton, Why Poor People Stay Poor, Fournal of Modern African Studies, 13, 167-73.

Batterbury, S (2001) Landscapes of Diversity: A Local Political Ecology of Livelihood Diversification in South West Niger, Ecumene, 8, 437-64. 


\section{Eric Waddell and Fohn Connell}

Bebbington, S (1999) Capitals and Capabilities. A Framework for Analysing Peasant Viability, Rural Livelihoods and Poverty in the Andes, London: International Institute for Environment and Development.

- Dharmawan, L, Fahmi, E and Guggenheim, S (2004) Village Politics, Culture and Community-driven Development: Insights from Indonesia, Progress in Development Studies, 4, 187-205.

Blaikie, P and Brookfield, H C (eds) (1987) Land Degradation and Society, London: Methuen.

_ and Muldavin, J (2004) Upstream, Downstream, China, India: The Politics of Environment in the Himalayan Region, Annals of the Association of American Geographers, 94, 520-48.

- Cameron, J and Seddon, D (2002) Understanding 20 Years of Change in West-Central Nepal: Continuity and Change in Lives and Ideas, World Development, 30, 1255-70.

Brison, K (2003) Imagining Modernity in Rural Fiji, Ethnology, 42, 335-48.

Brookfield, H C (1973) The Pacific Realm, in M W Mikesell (ed.), Geographers Abroad: Essays on the Problems and Prospects of Research in Foreign Areas, Research Paper No. 152, Department of Geography, The University of Chicago, 70-93.

- (1975) Interdependent Development, London: Methuen.

— (2001) Exploring Agrodiversity, New York: Columbia University Press.

_ Parsons, H and Brookfield, M (eds) (2003) Agrodiversity: Learning From Farmers Across the World, Tokyo: The United Nations University.

Chossudovsky, M (2003) The Globalization of Poverty and the New World Order, Montreal: Centre for Research on Globalization (2nd Edition).

Clarke, W (1971) Place and People. An Ecology of a New Guinean Community, Canberra: Australian National University Press.

Connell, J (2007) The Fiji Times and the Good Citizen. Constructing Modernity and Nationhood in Fiji, The Contemporary Pacific, 18(1) (in press).

— and Rugendyke, B (2005) Harold Brookfield, in D Simon (ed.), Fifty Key Thinkers in Development, London: Routledge, pp. 56-61.

Cramb, R (1998) Environment and Development in the Philippine Uplands: The Problem of Agricultural Land Degradation, Asian Studies Revierw, 22, 289-308.

Curry, G (2003) Moving Beyond Postdevelopment: Facilitating Indigenous Alternatives for 'Development', Economic Geography, 79, 405-23.

Escobar, A (2001) Culture Sits in Places: Reflections on Globalism and Subaltern Strategies of Localization, Political Geography, 20, 139-74.

Jolly, A R (1975) Redistribution with Growth - A Reply, IDS Bulletin, 7(2), 9-17.

Larner, W and Le Heron, R (2002) From Economic Globalisation to Globalising Economic Processes: Towards Post-structural Political Economies, Geoforum, 33, 415-19.

Latouche, S (1994) 'Développement Durable': un Concept Alibi. Main Invisible et Mainmise sur la Nature, Revue Tiers Monde, 35 (137), 77-94.

Lee, E and LiPuma, E (2002) Cultures of Circulation: The Imaginations of Modernity, Public Culture, 14, 191-213.

Mitchell, D (2001) The Lure of the Local: Landscape Studies at the End of a Troubled Century, Progress in Human Geography, 25, 269-81.

Nesbitt, J and Weiner, D (2001) Conflicting Environmental Imaginaries and the Politics of Nature in Central Appalachia, Geoforum, 32, 333-49.

Partant, F (1982) La Fin du Développement: Naissance d'une Alternative?, Paris: Maspero/La Découverte.

Purcell, M and Brown, G (2005) Against the Local Trap: Scale and the Study of the Environment and Development, Progress in Development Studies, 5, 279-97. 
Ramonet, I (1997) Géopolitique du Chaos, Paris: Galilée.

Radcliffe, S (2001) Development the State and Transnational Political Connection: State Formation and Networks in Latin America, Global Networks, 1, 19-36.

- (2004) Geography of Development: Development, Civil Society and Inequality Social Capital is (Almost) Dead?, Progress in Human Geography, 28, 517-27.

Rigg, J (2001) Embracing the Global in Thailand: Activism and Pragmatism in an Era of Deagrarianisation, World Development, 29, 945-60.

- (2002) Of Miracles and Crises: (Re-)interpretations of Growth and Decline in East and Southeast Asia, Asia Pacific Viewpoint, 45, 137-56.

Rostow, W W (1991) The Stages of Economic Growth: A Non-Communist Manifesto, Cambridge: Cambridge University Press (3rd Edition).

Sahlins, M (1993) Goodbye to Tristes Tropes: Ethnography in the Context of Modern World History, Fournal of Modern History, 65, 1-5.

Scoones, I (1999) New Ecology and the Social Sciences: What Prospects for a Fruitful Engagement?, Annual Review of Anthropology, 28, 479-507.

Scott,J C (1976) The Moral Economy of the Peasant, New Haven, CT: Yale University Press.

Simon, D (2003) Dilemmas of Development and the Environment in a Globalizing World: Theory, Policy and Praxis, Progress in Development Studies, 3, 5- 41.

Smith, E A and Wishnie, M (2000) Conservation and Subsistence in Small-scale Societies, Annual Review of Anthropology, 29, 493-524.

Sturgeon, J (2004) Border Practices, Boundaries and the Control of Resource Access: A Case for China, Thailand and Burma, Development and Change, 35, 463-84.

Watts, M (1983) Silent Violence: Food, Famine and Peasantry in Northern Nigeria, Berkeley, CA: University of California Press.

- (2002) Alternative Modern - Development as Cultural Geography, in K Anderson, M Domosh, S Pile and N Thrift (eds), Handbook of Cultural Geography, London: Sage, pp. 432-53.

Woodbridge, R (2004) The Next World War: Tribes, Cities, Nations and Ecological Decline, Toronto: University of Toronto Press. 


\title{
2 Volcanic eruption as metaphor of social integration

\author{
A political ecological study of \\ Mount Merapi, Central Java
}

\author{
Michael R. Dove ${ }^{1}$
}

While carrying out a study of the human ecology of Merapi volcano in Central Java in the 1980s, it became apparent that villagers represented the imminent threat of volcanic hazard as a feeling of being confused (bingung) or lost (kesasar), and of being lured away from their homes and into the crater by spirits masquerading as friends. The villagers thus saw this hazard as a loss of home and identity. Subsequently, in the wake of a deadly eruption in 1994, this was interpreted by wider Javanese society as presaging a millenarian loss of identity and transformation of society. A central feature of this volcanic landscape was thus a threat to identity not just on the part of the local community but of the entire society.

Interest in how local communities and wider society relate under conditions of environmental duress has been stimulated by the rise over the past two decades of political ecology. A pivotal figure in this rise was Harold Brookfield, who coauthored in 1987 one of the field's canonical works, Land Degradation and Society, which laid out the framework of what has proved to be a powerful and influential analytical paradigm. Its subject matter was characteristically some sort of humanecological perturbation, often resource degradation, and the attendant dialectical relations between society and environment (Blaikie and Brookfield 1987: 17; Brookfield and Byron 1993). The most important contribution of this approach lies in seeking the causes and consequences of such perturbation beyond the local level. It is explicitly committed to seeing how perturbation or degradation is affected by (and also affects) relations with extra-local actors.

Central to this approach, which Brookfield termed 'regional political ecology', is the study of political and economic relationships across unequal scales and hierarchies:

The complexity of these relationships demands an approach which can encompass interactive effects, the contribution of different geographical scales and hierarchies of socioeconomic organizations (e.g. person, household, village, region, state, world) and the contradictions between social and environmental changes through time. Our approach can be described as regional political ecology.

(Blaikie and Brookfield 1987: 17) 
This approach focuses both on the state and on people and environments that appear to be at the periphery or margins of the state (and indeed in the concept of marginality itself) ${ }^{2}$ as well as in the dynamics of resource-related relations between political centres and peripheries. In order to understand apparently local systems of resource use, conservation and degradation, we must understand the way that such systems are integrated into wider society. Accordingly, one of the emphases in political ecology has been to challenge premises of non-integration and associated discourses of division, which still dominate much conservation and development thinking. The approach taken by Brookfield and his followers is based, in part, on problematizing the construction of such simplistic divisions, especially between local and non-local and the related division between traditional and modern. This approach underpins much of the recent work and interest in hybridity (e.g. Gupta 1998), the discovery that modernity is characterized by mixtures that invalidate many of the classificatory schema by which modernity has been commonly understood.

This chapter seeks to show how local, regional and national beliefs regarding volcanic eruption and hazard not only reflect the wider linkages within Indonesian society but also actually help to reproduce these linkages. Recent scholarship in Indonesia treat these beliefs not simply as the traditional and 'exotic' material that they may appear to be but as central and disputed concepts in a national struggle for power, legitimacy and also identity. As Tsing writes:

The ritual forms that have developed possess deep roots in regional cultures across Indonesia; yet their contemporary importance shows not their timeless authenticity but, rather, their current centrality in national projects and their local renegotiations.

(Tsing 1993: 298)

This interest in connecting ideology and politics builds on the work of Benedict Anderson, one of the doyens of modern Indonesian studies, who has represented it as the challenge 'to link the splendors of the imagining life with the remorseless engines of global economic and technological change' (Anderson 1990: 8).

This analysis mainly draws on field data gathered on Merapi volcano, in the community of Turgo, from January 1982 until May 1985, in collaboration with students and colleagues in the Department of Anthropology at Gadjah Mada University in nearby Yogyakarta. The study focused on the ethno-ecology of the system of agriculture and animal husbandry practiced on the slopes of the volcano. Particular attention was paid to the impact of volcanic activities and hazards on this system of natural resource use and on local bodies of knowledge for comprehending and managing these activities and hazards. Another major body of data was gathered in the immediate wake of the major eruption of Mount Merapi on 22 November 1994, concentrating on the interpretation of this eruption by the wider Indonesian society, as articulated in regional and national news media. 


\section{Society and environment on Mount Merapi}

A generation ago, studies of natural hazards and disasters emphasized technologically oriented analysis and mitigation of disaster (Kates and Burton 1986). Since then an alternate approach has developed - within academia if not within the disaster policy and relief community - which emphasizes political-economic study of the concept of disaster itself, exemplified by the work of Hewitt (1983) and Wisner (1993). This has also stimulated ethnographic studies of responses to natural hazard (e.g. Solway 1994; Waddell 1975; Watts and Bohle 1993), which are especially relevant here. Brookfield explicitly declared his regional political ecology approach to be compatible with this new approach to natural disasters (Blaikie and Brookfield 1987: 23).

A high proportion of the 175,000 global deaths due to volcanic eruption over the past two centuries have occurred in Java (Chester 1993: 271). Gunung Merapi ('the Fire Mountain') is the most active of 129 volcanoes on Java (Figure 2.1). Merapi has had at least thirteen major eruptions with human casualties since the year 1006 . However, since all but one of these recorded eruptions took place since 1672, poorer records from earlier times probably disguise a much higher toll. The deadliest eruption in historic times occurred in 1672, leaving a reported 3,000 people dead. One of the most feared aspects of Merapi, and characteristic of this type of

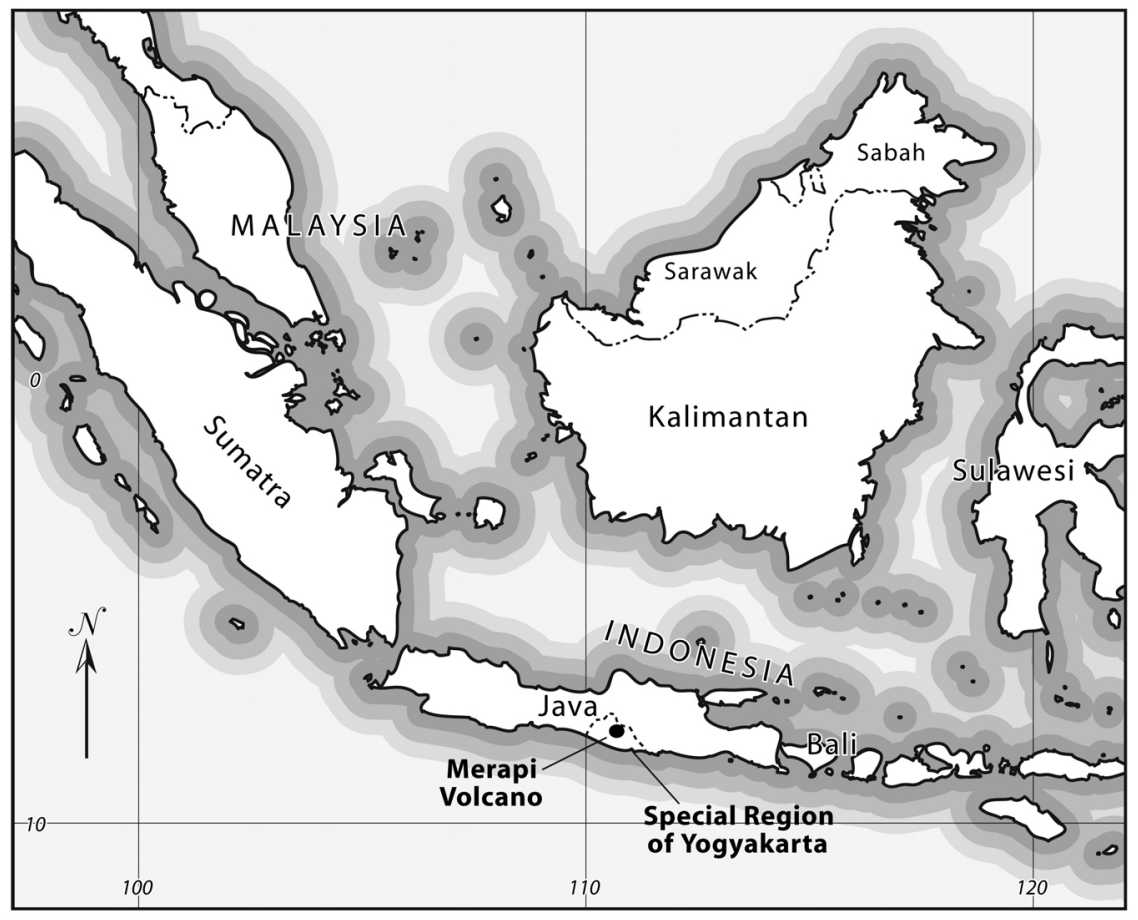

Figure 2.1 Location of Mount Merapi within Indonesia. 
volcano, is the eruption not just of magma but of revolving clouds of superheated gases. Called ampa'-ampa' in Javanese, awan panas in Indonesian (and nuée ardente in the international literature), these clouds descend the slopes at speeds of 200-300 kilometres per hour, bear temperatures of 200-300 degrees Celsius and present a far greater threat to life and limb than the much slower moving rivers of lava. Villagers on the slopes of Merapi commonly speak of only two volcanic hazards: the heated gases, and the mixtures of ash and water called lahar dingin (cold lava flows) which can also descend the slopes at great, destructive speed.

The 1994 eruption produced a gas cloud that rapidly travelled six kilometres down the southern slope of Merapi and four kilometres down the southeast slope, following two riverbeds (Figure 2.2). The inhabitants of a dozen villages on these slopes fled the gases on foot down the mountain, but 56 died on the spot or subsequently from injuries, and 4,452 were evacuated to refugee camps down the mountain. Turgo, which had not been hit by an eruption within recorded history, was the hardest hit village. The casualties there and elsewhere on the mountain prompted a debate in the press over why the eruption was not better predicted, why villagers were not given more advance warning and, especially, whether affected villagers should be moved off the mountain for their own safety.

\section{Turgo village}

Turgo is a hamlet of several dozen households. It has long been the highest inhabited village on the southern slope of Merapi. Lying 600 metres above sea level,

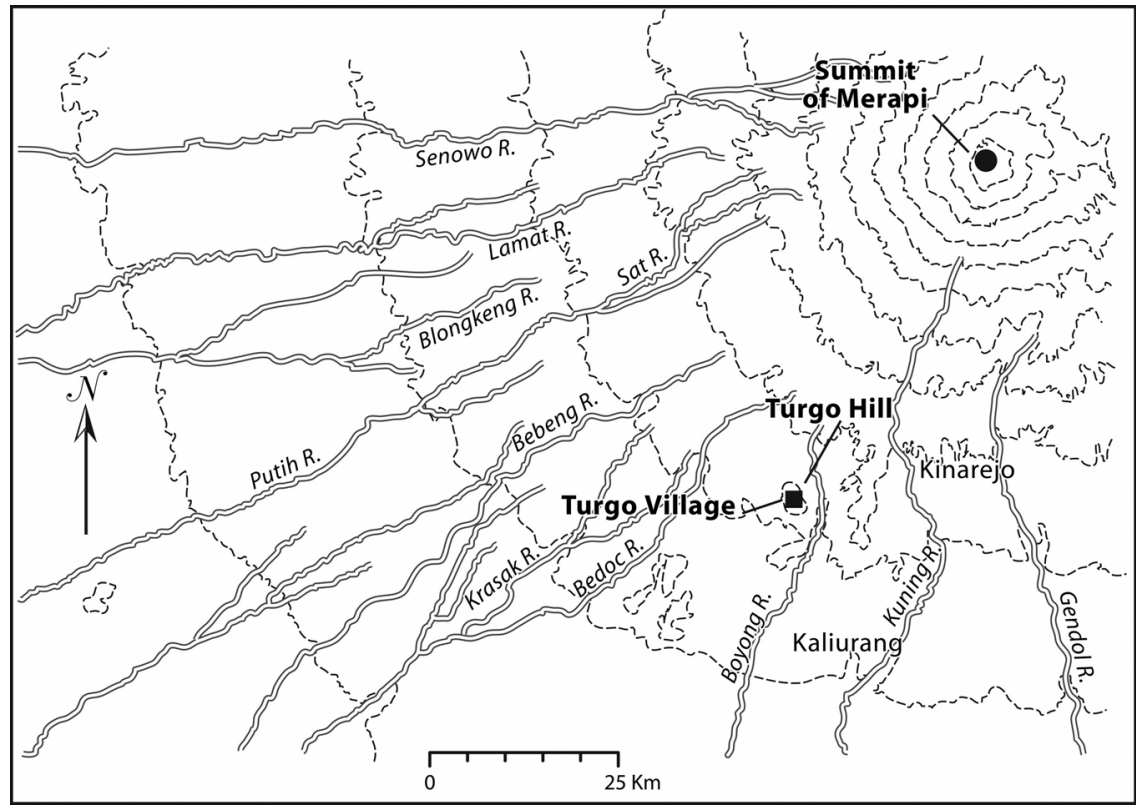

Figure 2.2 Mount Merapi, Java. 
Turgo is approximately eight kilometres from the summit and crater of Merapi, which rises to 2,962 metres above sea level. Turgo is quite unlike the popular image of a Javanese village; it has no sawah pond-fields, like those that dominate much of lowland Java, and at the time of the 1994 eruption its inhabitants mostly ate maize (cooked into a rice-like gruel) and tubers, grown in a distinctive land-use system (Boomgaard 1998), ${ }^{3}$ rather than rice.

There have always been many exceptions to the stereotyped, idealized image of the Javanese village, its culture and agriculture (Hefner 1985). This was especially true when swidden agriculture was still practised widely in the island's upland forests (Dove 1985). Indeed, Turgo villagers are said to have practised swidden agriculture until the beginning of the twentieth century, when wono swiddens made within the forest gave way to tegalan permanent fields made on open, continuously cultivated lands (Pranowo 1985). Turgo villagers characterize this historic shift as one from an agricultural system in which fertility was guaranteed by moving within the forest (utilizing a long, forest fallow to restore fertility), to one where fertility is guaranteed by replenishing the soil with fertilizer every harvest or two.

The fertilizer on which the agricultural system depends is not purchased from markets but produced by the villagers' own cattle. Cattle are a central component of the agricultural economy, raised for the sale of their milk and meat, for their usefulness as a means of 'banking' surplus resources against the time that they are needed, and for their production of manure (Hudayana 1987). During the wet season, cattle can mostly be fed with grasses cultivated or growing naturally on fields near the village; in the dry season, these sources are insufficient and villagers must daily gather fodder from grasslands higher on the flanks of the volcano (Figure 2.3), which are kept moist by the cloud cover that typifies higher elevations. These higher-elevation grasslands in effect subsidize the productivity of the lowerelevation agricultural fields in a form of forest-farm linkage known the world over (Blaikie and Brookfield 1987: 46; Pandey and Singh 1984).

These grasslands are dominated by Imperata cylindrica, which is cut and carried down the mountain to stables for stall-feeding to cattle (Dove 1986; Sherman 1980). Turgo villagers say that the grasslands - which lie below the treeline - are periodically scorched by hot gas clouds erupting from the crater. Imperata has a competitive edge in any such fire-dominated environment because its extensive below-ground root system and fast growth favour its rapid regeneration after being burned. The villagers themselves believe that eruptions favour the growth of grasslands versus forests on Merapi's higher flanks and that falls of ash every few years help to keep these grasslands productive (Blong 1982: 186). ${ }^{4}$

\section{Disaster discourses}

Although a focus of interest for centuries, Merapi drew special attention in the years leading up to and following the collapse of President Suharto's New Order regime. One of the fascinating features of this attention - whether from Turgo villagers, local activists, the Yogyakarta royal court or government scientists and officials - is that it was all contained within a similar, analogical framework, where 


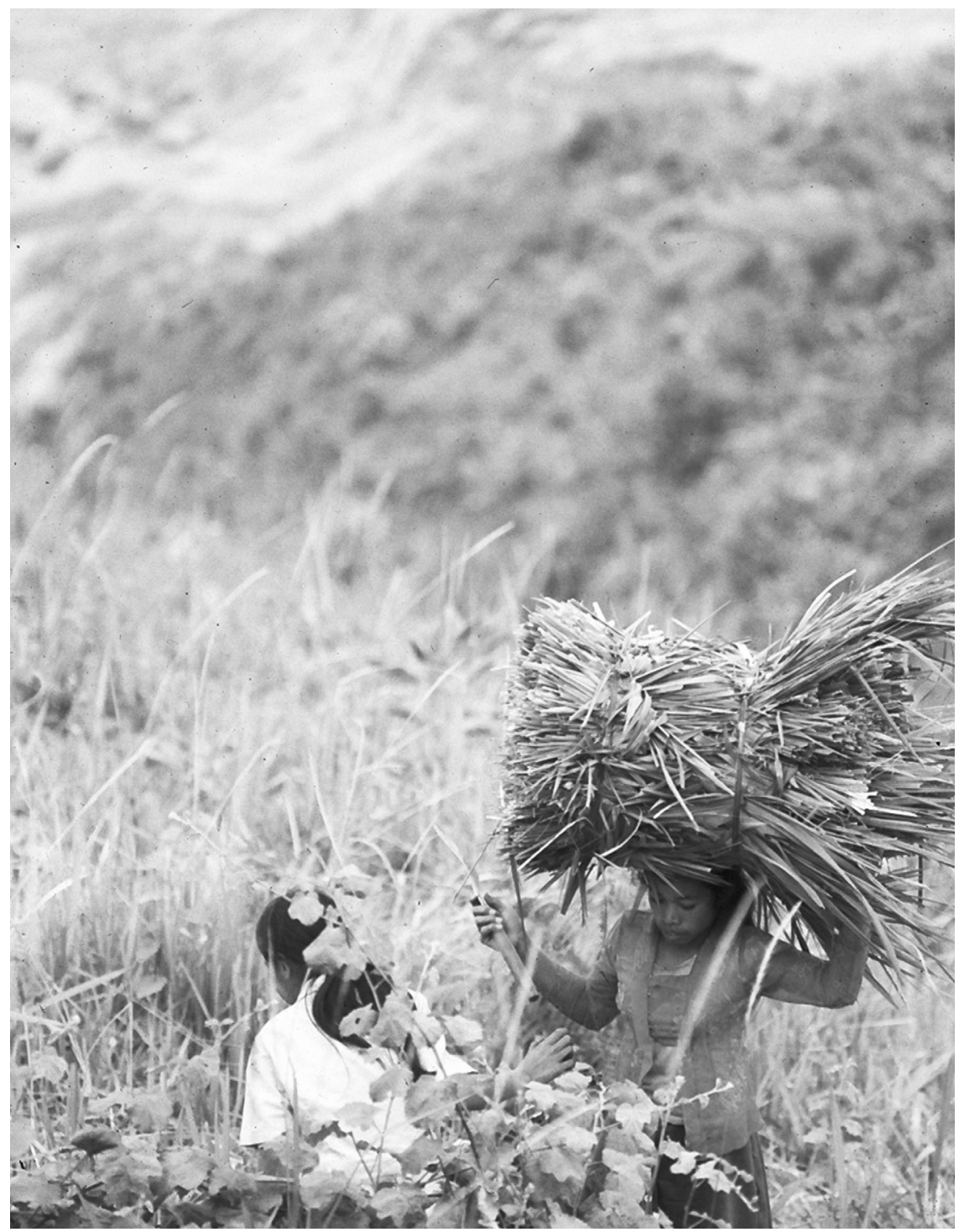

Figure 2.3 Villagers gathering grasses on the high slopes of Mount Merapi, Java.

the behaviour of the volcano not only affects but also reflects behaviour in the ordinary world.

\section{The village discourse}

As noted earlier, villagers on the slopes of Merapi express the threat of volcanic hazard as a feeling of getting lost, being confused and being invited (diajak) to go 
away, with the danger expressed as kesasar di hutan (getting lost in the forest). This is a discourse not of material hazard but of spiritual liminality and loss. These beliefs were widely reported in the press in the wake of the 1994 eruption, even among people whose bodies were burned by hot gases. This response to natural hazards is not peculiar to Java. In a global overview, Hewitt (1997: 42) wrote that 'Survivors of disaster recall, among their first sensations, not knowing where they are, even in their own homes. They speak of being disoriented, lost and unable to recognise anything'.

Mount Merapi villagers say that those who try to lead them away while in this state of loss and confusion are wewe (female spirits), who appear to us as relatives or close friends. The feeling of going off with the wewe is said to be like rasa pulang ke kampung sendiri-pada hal makin keatas (the feeling of going home to one's own village - whereas in fact you are going continually upwards [toward the crater, and the home of the wewe]). Danger thus lies in being lured away from one's own home to someone else's home, from a place where one belongs to a place where one does not belong. Volcanic hazard is interpreted as a threat to domestic identity. This is ultimately a threat of alienation: the greatest sort of alienation is not just to leave home for the unknown but to feel like going home when you are not. As Hewitt (1997: 43) wrote, "A further way in which this [the impact of natural disaster] is expressed is the sense of being "a stranger" or of feeling "strange" in the home area.'

The power of this interpretation of volcanic hazard lies in the fact that the journey towards the crater of the volcano - towards that most 'other' of places - is perceived as a journey toward home. The power of this discourse comes from the fact that what feels to the villagers like home is actually something far different: the quintessential other. The extent of this otherness is emphasized in stories about those who recover sufficiently from their loss and confusion to return home, bringing evidence of what this spirit world is like. One story, told by Turgo villagers of someone who got 'lost' on the volcano, records:

Cerita orang mau ke pasar, kesasar, beli jadah, penjual tidak bicara, kembali ke desa, ternyatajadah ada batu gepeng. (This is a story of someone who went to the market to buy rice cakes, the seller did not speak; when he returned to the village, the rice cakes turned out to be flat rocks.)

This story, with its juxtaposition of rice cakes and rocks, highlights the otherness of the volcano's crater and the magnitude of the transformation involved in the villagers going there. Hewitt (1997: 46) similarly observes that 'Everyday life becomes the reference frame of extreme experience... The meaningful vocabulary [of disaster] is not of spatial abstractions but the concrete terms of everyday life.'

Turgo villagers, like most Central Javanese, believe that there is another world within the crater of Merapi, which they characterize as a parallel to, or replica or miniature of, their own, and which they believe to be inhabited by baureksa (spirits). According to the Javanese origin tale, Babad Tanah Fawi ('The Clearing of Java'), 
human settlement of the island drove all its spirits into the volcanoes and other marginal places, where they remain to this day (Geertz 1960: 23). In Javanese cosmology, the Merapi crater is thought to be the counterpart of the South Java Sea; both have spirit courts and rulers, and humans are called to both when there is need for labour, much as a traditional Javanese ruler would call upon his people. In many respects, therefore, 'life' in Merapi is thought to resemble the everyday life of the Javanese. ${ }^{5}$ Turgo villagers, in whose own lives animal husbandry looms large, can speak in detail about the purported animal husbandry of the spirits in Merapi. They believe that the spirits keep both horses and pigs - the latter being the wild pigs that are abundant on Merapi's slopes.

There are numerous, transformative linkages between the spirit palace in Merapi's crater and the everyday world of the villagers, including the stream of lost people who unknowingly depart this world for that within the crater, where they become servants of the spirit palace. Another example involves a macan (leopard) thought to belong to the Merapi spirits, which dwelt in a particular place on the upper slopes of Merapi. Villagers say that this leopard would not eat people, except for those who were unlucky (julung) and appeared to it as chickens or goats.

The most important linkage between the spirit world in Merapi's crater and the world of the villagers on its flanks involves volcanic eruptions. These eruptions are thought to be manifestations of the mundane, day-to-day activities of the spirit palace. It is believed that house-cleaning and house-building are scheduled in the Merapi palace during each Bulan Sura (the first moon of the Islamic calendar) and the dirt and waste produced by these activities is manifested in the ejection of what are perceived by villagers to be lahars, ash and gas clouds (Triyoga 1991). Thus, one well-known shaman from a village on Merapi's slopes suggested that the 1994 eruption was occasioned by the construction of a gerbang (ceremonial arch) in the spirit palace (Suara Merdeka 26/11/94). Some also believe that the eruptions represent the sallying forth of inhabitants of the spirit palace in a pawe (procession), headed by one of the volcano's foremost spirits (Kerto Dimejo) riding in a carriage. The eruptions are thought to follow a set direction and be limited in duration or extent. One of the most widely reported beliefs regarding Merapi is that its spirits will mark the intended extent of eruptions with benang (thread), so that villagers can stay out of harm's way. The overall effect of these beliefs is to demonstrate not just that there is a parallel reality in the volcano, but that there is an order to this reality, which is comprehensible to the Javanese living on its slopes.

\section{The court discourse}

Twenty kilometres to the south of the spirit palace of Merapi lies its real-world counterpart, the kraton (palace) of Yogyakarta, where the last ruling sultan in Indonesia still sits. The two palaces, spirit and mundane, are closely linked. This linkage is demonstrated most clearly during the labuhan jumenengan (offerings), which the Yogyakarta palace makes every twenty-ninth day of the seventh month (Rajab) of the Islamic calendar to Mount Merapi, to Mount Lawu to the east and on the 


\section{Michael R. Dove}

shore of the southern coast. To facilitate these offerings, the Yogyakarta palace maintains relations in each of these three places with a particular village, the desa kraton (palace village), and a particular ritual expert, the juru kunci (key master).

The Yogyakarta palace claims to have some influence over Merapi based on these ritual relations. It asserted these claims even in the wake of the 1994 eruption, with its heavy toll on life and property. For example, when reporters asked the Sultan of Yogyakarta why the palace had not been able to predict the eruption, given the 'mystical' connection between the volcano and the palace, the Sultan replied 'Kalau tanya firasat, ya tanya saja para korban itu' ('If you want to ask about prophecies, ask the dead') (Jawa Pos 24/11/94). The Sultan's implication was that the palace did predict the eruption, but too little attention was paid to its special knowledge, which is why people died. More explicitly, an official in the palace told the press that the eruption could not be blamed on insufficient offerings by the palace:

Mengingat sesaji dalam upacara labuhan jumenengan juga tidak pernah dikurangi atau ditambah. Jadi kalau ada yang mengatakan peristiwa meletusnya Gunung Merapi dan wedhus gembel yang mengarah ke Selatan karena ada kekurangan sesaji dari Kraton Yogyakarta tentu tidak benar. (Recollect that the offerings are never reduced or increased. Thus if anyone says that the incident of the eruption of Mount Merapi with its gas cloud that descended to the South was due to deficiencies in the offerings from the Yogyakarta palace this of course is not true.)

(Kedaulatan Rakyat 9/12/94a)

Accounts from outside the palace went beyond this to suggest not only that the Yogyakarta palace did its job, but that it actually minimized the magnitude and destructive impact of the 1994 eruption. ${ }^{6}$ One of Yogyakarta's spiritual leaders had buried an heirloom kris (ritual dagger) on Merapi and thereby delayed by several years the eruption that eventually occurred in 1994 (Suara Merdeka 24/11/94a). This same expert asserted that there had been a protracted tawar-menawar (negotiation) between spiritual leaders and the spirits of Merapi, and the eruption on 22 November 1994 represented the expiration of the period of grace that the former had won from the latter. He added that the timing of the eruption at 10:15 in the morning also reflected considerable 'tolerance' on the part of the spirits of Merapi, because if it had occurred at night when people were asleep, casualties would have been far higher.

An eruption like that in 1994, with its considerable toll of human casualties and property damage, notwithstanding claims that it would have been worse without 'negotiations', inevitably raises questions as to whether palace influence is waning. The challenge to the control of the Yogyakarta palace that was posed by the 1994 eruption was most directly made in comments in the press about the direction of the eruption, which was to the south, towards Yogyakarta (Figure 2.1) (e.g. Suara Merdeka 11/12/94), the one direction in which eruptions should not go if the palace's authority over Merapi was holding strong. 


\section{The state discourse}

Unease about the political symbolism of the eruption was at least as great in the national government as in the Yogyakarta court. This is reflected in the amount of high-level political attention that the 1994 eruption received, which included early and close involvement in aid efforts by former President Suharto himself, including a visit to the evacuee camps. Sensitivity on this issue was also reflected, in the aftermath of the eruption, in the public debate as to whether or not the government's Vulcanology Service had provided adequate warning of the eruption. The Minister of Mining and Energy, with authority over the Vulcanology Service, complained to the National Assembly that he was slandered by a political cartoon that depicted a vulcanologist asking 'What's happening, what's happening?' while villagers fleeing the eruption ran past him (Suara Merdeka 1/12/94). The minister asserted that his service had previously warned the government of an imminent eruption eighteen days before it occurred and had advised the Yogyakarta government to resettle all villagers out of the danger zone.

The Vulcanology Service is a world-class institution, developed by the national government with international assistance, devoted to the study of Merapi, the monitoring of its activity and the dissemination to the public of warnings (Chester 1993: 292). The service has mapped out the zone judged unsafe for human habitation, with sub-rankings from 1 to 3 (from most to least dangerous), and developed a ranking system for the day-to-day condition of the volcano, with current rankings routinely publicized around the volcano. From least to most dangerous, these are: Aktif Normal (Normally Active), Waspada Merapi (On Guard [for] Merapi), Siap Merapi (Prepared [for] Merapi) and Awas Merapi (Beware Merapi). At the time of the 1994 eruption, the service was issuing daily, well-publicized, press briefings on the state of the volcano (drawing data from its monitoring stations on Merapi's slopes), an example of which follows:

Kemarin, tidak terjadi gempa vulkanik, gempa low frequency, maupun gempa tremor. Hanya terjadi gempa fase banyak 2 kali dan guguran lava 88 kali. (Yesterday, there were no volcanic earthquakes, low frequency earthquakes or earth tremors. There were only two multi-phase earthquakes and 88 discharges of lava.)

(Suara Merdeka 8/12/94)

Not only did these briefings emphasize the government's understanding of and thus, to some extent, authority over the volcano, but their use of an esoteric, scientific language emphasized the exclusivity of this authority in representing the activity of the volcano to the public. ${ }^{7}$

The state's unusually great and long-standing commitment to volcanic research and monitoring reflects the importance to it of encompassing volcanic activity within its orbit (Chester 1993: 292). ${ }^{8}$ This commitment is not commensurate with the annual toll in life and property due to volcanic activity compared with malnutrition or infant mortality, or even other natural perturbations such as landslides and flooding. There is something special about volcanic hazards: death and 
destruction due to volcanic activity are 'privileged' in a way that other deaths are not, including those, for example, in the transmigration sites to which evacuees are sent. ${ }^{9}$

\section{The NGO discourse}

The 1994 government response to natural hazard on Merapi drew the attention of a non-governmental organization (NGO) in Yogyakarta called Wong Gunung ('Mountain People'), which focuses on social justice matters. In their newsletter, Gunungan ('Mountains'), they not only critiqued the wider political-economic context in which the state program of evacuation and resettlement was set, but they problematized the state discourse of natural disasters and state relief, and local vulnerability and weakness, and turned it back on the state. One of their most effective rhetorical ploys was to replace the state emphasis on 'natural disaster' with an emphasis on 'man-made disaster'. Writing about the inefficiency and corruption that kept aid assistance out of the hands of the people who needed it, they stated: 'Bencana yang sesungguhnya berasal dari aparat yang mentalnya bobrok itu bukan dari gunung Merapi' ('The real disaster comes from the mental degenerates in government, not from Merapi') (Gunungan 25/1/95). They similarly challenged implicit representations of the state program as transparent and rational in comparison with the purported opaqueness and irrationality of local society on Merapi. Thus they wryly referred to the disappearance of assistance funds for the refugees: 'Selalu ada dana-dana yang merubah menjadi mahluk-mahluk halus yang sulit terdeteksi atau dilacak' ('The funds seems to be transformed into spirits that are difficult to find or to trace') (Gunungan, 25/1/95).

They were particularly sceptical of the motives driving the government resettlement programme. For example, when the step-brother of then President Suharto publicly offered to take 500 refugee families to work on his cocoa and oil palm plantations in Bengkulu, Sumatra (Suara Merdeka 28/11/94), they asked whether the offer represented a real effort to help these families or was just an attempt to take advantage of the situation to obtain cheap plantation labour (Gunungan 25/1/95). They compiled a list of implicit motives for the government's support of an emergency relocation program: (1) it makes local land ownership in the evacuated zone more easily contestable by outsiders; (2) it thereby supports long-term plans of distant elites to develop the evacuated zone for tourism and agribusiness; (3) it generally supports the interests of those with economic and political capital; and (4) it gets the costs of this resettlement paid by international disaster relief organizations instead of the national government.

The heart of the NGO's analysis thus lay in drawing a connection between national economic enterprises and marginal peasantries, between centre and periphery and, especially, between perturbed and unperturbed landscapes. It emphasized how relief and other state responses to disaster are not separate from but integrated into the everyday political economy. It shows the speciousness of a view of disaster as isolated in time and space. In short, the NGO's assessment was much in keeping with that in the work of Hewitt and Watts, in arguing that the 
portrayal of disaster or degradation as a segregated landscape is highly problematic - an argument with clear intellectual antecedents in Brookfield's work.

\section{The wider politics of volcanic hazard}

As the NGO's commentaries make clear, the state's public construction of Merapi's eruptions as a localized natural hazard was problematic. Such a construction is a political act, driven by political issues and contests that are imbricated in the way that volcanic hazard is both perceived and responded to.

\section{Transmigration/resettlement}

The villagers of Turgo and the surrounding communities, despite their apparent isolation, live within a centralized state with a long tradition of close management of rural landscapes. In Dutch colonial times, state concerns on the slopes of Merapi focused not only on volcanic hazard, but also on such things as retarding soil erosion and maintaining forest cover. In more recent times, state concerns have encompassed production forestry, tourism, mining and now agribusiness. State interventions included 'closing' the forests to settlement and cultivation in colonial times and, in contemporary times, involving some villagers in afforestation and soil conservation efforts through agroforestry programs while transmigrating other villagers off the volcano for reasons related to hazard and conservation. ${ }^{10}$ The most recent proposed intervention is to establish a national park on Merapi's upper slopes, which many villagers and local activists oppose. State interest in the safety of the inhabitants of Merapi's slopes and in ensuring this through resettlement have increased after every major eruption. For example, the deadliest eruption during the forty years leading up to the 1994 eruption occurred in May 1961, destroying 109 homes and killing five people. This was followed by the transmigration of 1,905 villagers (Suara Merdeka 9/12/94). In 1978, in the wake of a smaller eruption of hot gases and ash, the village of Turgo was actually officially 'erased' (dihapus) from government maps, although its inhabitants were allowed to continue living there. ${ }^{11}$ The eruption on 22 November 1994, with a death toll exceeding anything experienced on Merapi since 1930, intensified the debate about the safety of life on Merapi's slopes and the virtues of resettlement by the state.

Merapi villagers display remarkable unanimity in their opposition to transmigration. In the aftermath of the 1994 eruption, 7,962 households in villages lying in the danger zone (in the kabupaten (regencies) of Magelang, Boyolali and Klaten) were interviewed and less than one per cent (68 households) expressed any interest in transmigrating (Suara Merdeka 7/12/94). So unnerved were some villagers at the mere mention of transmigration that they fled the refugee camps where the interviews took place and returned to their still off-limits villages on the volcano. Many villagers, in short, saw the government resettlement program as just another hazard (and a very similar one - for just as volcanic spirits contest the reality of their homes, so does the state) and preferred the hazard they knew to the one they did not. Following the eruption, one evacuee told the press: 'Fika ia harus mati disebabkan 
oleh bencana Merapi, itu sama dengan mati ngrungkebi negara' ('If you have to die because of the hazards from Merapi, it is the same as dying from giving up to the state') (Kedaulatan Rakyat 8/12/94). Local activists drew a similar parallel: 'Bencana kedua ini, tidak saja membakar menjadi arang tubuh manusia tetapijuga jiwa' ('This second hazard [of relocation being pushed by elite developers] does not just burn people's bodies and turn them into charcoal but also [burns] their spirits') (Gunungan 25/1/95).

As an alternative to transmigration, the people of Turgo were offered the more palatable option of moving out of the temporary refugee camps into a newly built resettlement hamlet called Sidomoro, about ten kilometres down the mountain from their old village. The houses in Sidomoro, built with public donations, were relatively well built for a state project of this sort, and those who settled there received considerable state aid. No aid was given to villagers who returned to Turgo. However, Sidomoro was built on land appropriated by the state from a nearby and long-established village, which created local resentment against the new settlers. In addition, because of local population pressures, no agricultural or grazing land was allotted to the inhabitants of Sidomoro, who were obliged to keep working their own lands in Turgo, difficult though this was because of distance. A lack of other economic opportunities in the vicinity of Sidomoro has generally made the economics of life there difficult. Consequently, of the villagers who initially opted to move into Sidomoro, most had returned to Turgo within a month of the eruption. Today, there are approximately 80 households in Turgo and just 60 in Sidomoro, and the latter number is gradually declining as villagers gradually return to Turgo.

\section{Natural resources}

Little official effort has been made to fathom the rationale behind the determination of 99 per cent of the local populace to remain on the mountain. 'Masih ada sebagian warga yang enggan ditransmigrasikan' ('There are still some people who do not want to transmigrate') (a local transmigration official, Suara Merdeka 7/12/94). Some outside observers attributed villagers' reluctance to leave the mountain to the valuable deposits of sand left on its flanks by periodic eruptions, especially of lahar dingin, and the ability of villagers to mine it for sale to construction companies (Suara Merdeka 7/12/94). Outsiders mention the sand mining because this is one of the few resource-use systems on the volcano that is visible to them. Until the 1994 eruption Turgo villagers focused their economic energy on subsistence cultivation of maize and tubers; since the eruption they have concentrated on the production of milk and meat (and to a lesser extent fuelwood and fruit) for the market. There has been virtually no outside interest in or knowledge of either production system. ${ }^{12}$

The wider society's lack of interest in local systems of resource use, and its emphasis on volcanic hazards and need for transmigration or resettlement, is associated with keen interest in rival systems of resource use. Interest on the part of both public and private sector actors has extended in recent years, not only to sand mining but also to newer and more lucrative developments in tourism, agribusiness and park management. Plans to develop tourist villas on lands to be relinquished by 
transmigrants circulated so widely in the wake of the 1994 eruption that the Minister of Transmigration was forced by the press to address them, as follows:

Rencana itu, menurut Siswono, semata-mata untuk menyelamatkan warga yang bertempat tinggal di daerah rawan bencana. Meski begitu, pihaknya tidak akan memaksa kalau masyarakat menolak program itu. (That plan [to construct villas], according to Siswono [the Minister], was simply to save people who reside in the area disturbed by the disaster. However, no one will force [the issue] if the villagers reject the program.)

(Kedaulatan Rakyat 9/12/94b)

The fact that some of the alternate resource uses being proposed were no less vulnerable to volcanic hazard than the existing community uses raised questions regarding government motives, as reflected in this comment from a Merapi villager published by local activists:

Kaliurang itu letaknya sïajar dengan kami. Jadi kemungkinan terkena bencana itu sama besarnya dengan kami. Itu tidak dipermasalahkan. Malah kami yang dipermasalhkan. (Kaliurang [a tourist centre] is at the same altitude as we are. Thus the likelihood of [their] being struck by disaster is just as great as with us. But that is not a problem. Instead we are the ones that are the problem.)

(Gunungan 25/1/95)

\section{Symbol of change}

External interest in accentuating the vulnerability of the villagers on Merapi's slopes is not driven solely by interest in immediate material gain. Events such as the 1994 eruption not only raise questions about the ability of rulers to protect their subjects from natural hazards, they also raise much wider and more threatening questions about their fundamental mandate to rule (Anderson 1972; Harwell 2000a; Keeler 1988). In Java and throughout Southeast Asia (Adas 1979), perturbations in the natural realm are interpreted as presaging perturbations in the socio-political realm. ${ }^{13}$ The history of Java is replete with examples of this: the first recorded eruption of Merapi, in 1006, is popularly credited with toppling the kingdom of Mataram (whose capital lay where Yogyakarta is today), driving the Hindu kingdom to Bali and precipitating the Islamicization of Java (Decker and Decker 1997). The court chronicle of the later sixteenth to eighteenth century state of Mataram, the Babad Tanah Fawi, describes the circumstances of the fall of King Amangkurat (1645-77) as follows (cited in Moertono 1968: 74): 'sun and moon eclipses occurred frequently; rain was falling out of season; a comet was seen every night. Ash-rain and earthquakes [occurred]. Many omens were seen. There were signs that the kingdom was facing ruin'. Adas (1979: 140) notes that the revolt of Dipanagara (a Yogyakarta prince) against the Dutch in 1825-30 was preceded by 'famine, cholera epidemics, and volcanic eruptions'. Kartodirdjo (1984: 66-67, 166-68) suggests that the 1888 peasant revolt against the Dutch in Banten, northwest Java, 
was influenced by both the occurrence and prophecy of human and cattle epidemics, earthquakes and the eruption of Krakatau in 1883. Keeler (1988: 98) links the 1965-66 communal violence on Bali to the eruption of Gunung Agung in 1963. And indeed, during the years following Merapi's 1994 eruption, Indonesia was shaken by financial, political and environmental crises, which culminated in the collapse of President Suharto's three decade reign, which accorded with some of the predictions made in the wake of the eruption. ${ }^{14}$

In the case of Merapi, this linkage between natural and social perturbation is associated with previously discussed beliefs that within Merapi there exists a parallel world to our own and whose activities mirror our own: perturbation in the one world is mirrored by an equal perturbation in the other. There is an explicit discourse to this effect in Central Java: in the wake of the 1994 eruption, a ritual expert opined that this ledakan gunung (explosion of the mountain) would be followed by a ledakan politik (explosion in politics) (Suara Merdeka 24/11/94a). The ritual expert who made this comment went on to say:

Dalam pandangan spiritualnya, bencana alam gunung meletus dan angin ribut seperti yang terjadi sampai Selasa lalu, merupakan replika atau minatur alam semesta atau jagat raya terhadap manusia. (From a spiritual perspective, natural disasters like volcanic eruptions and wind-storms such as took place last Tuesday [22/11/94], represent, in microcosm, humanity's place in the universe.)

(Suara Merdeka 24/11/94a)

Javanese beliefs that associate volcanic eruption with social change have a millenarian character. ${ }^{15}$ One Turgo elder recounted a prediction that he first heard during his childhood in the first decade of the twentieth century, according to which within fifty years Merapi would erupt and destroy itself, which would be followed by three days of darkness, after which all bad people would disappear and a new ruler would appear. After the 1994 eruption, a ritual expert in Yogyakarta recounted to the press a purported janji (agreement) between humans and spirit deities, according to which $\mathcal{N}$ usantara (the Indonesian archipelago) would decline for 500 years following the fall of the kingdom of Majapahit (between 1513 and 1528), after which its glory would be restored (Suara Merdeka 24/11/94a). The expert added that a volcanic eruption, like the one in 1994, was supposed to signal the imminence of this restoration. The millenarian stories that then circulated all suggested that just as decline would be succeeded by glory, so would hidden sins be revealed, bad people would give way to good and injustice would be replaced by justice. ${ }^{16}$

Integral to these millenarian stories is a belief that things must get worse before they get better. A ritual expert in Yogyakarta observed that the coming of the new world would be signified by a breakdown in social as well as cosmological order (Suara Merdeka 11/12/94). It was widely suggested that Merapi's eruption signified the onset of an analogous perturbation of the social fabric. ${ }^{17}$ One ritual expert predicted that they would have to experience zaman edan ... yakni rusaknya moral bangsa, terjadinya penindasan, penggusuran, korupsi, dan sebagainya (an age of chaos ... 
meaning a breakdown in the nation's morality, oppression, condemnation, corruption and such like) before they could experience kembalinya bangsa Indonesia ke ajaran keluhuran, keyakinan batin dan agami Budi fawi (a return of the Indonesian nation to the teachings of our ancestors, to spiritual convictions and to the Javanese religion) (Suara Merdeka 24/11/94a). ${ }^{18}$

One aspect of the perturbation that must precede the good age to come is an assault on identity. Millenarian change such as that symbolized by the 1994 eruption is thought to first challenge and then reaffirm knowledge of self. As one ritual expert in Yogyakarta put it: Pada akhirnya akan terjadi gara-gara, yaitu manusia Indonesia termasuk pemimpinnya, lupa diri (Turbulent times are coming, in which Indonesians including their leaders will lose their identity) (Suara Merdeka 24/11/94a). ${ }^{19}$ This perceived linkage between transformations in the social and natural orders exemplifies the dialectic that is at the heart of Brookfield's political ecology (Blaikie and Brookfield 1987: 17).

\section{Conclusion}

In Javanese thought, Merapi is explicitly integrated into wider systems in a number of ways. Thus the Yogyakarta palace makes its offerings to Merapi in the context of a wider, regional series of offerings (encompassing Mount Merapi, Mount Lawu and the South Java Sea), the unity of which is sacrosanct. When the palace official cited earlier said that the offering to Merapi would be unaffected by the 1994 offering, he noted that Rangkaian ini tentu tidak dapat dipisahkan satu dengan lainnya (This chain [of offerings] of course cannot be separated one from another) (Kedaulatan Rakyat 9/12/94a). The implication is that the separate parts of the chain together constitute a whole (which broadly circumscribes the territory of the traditional kingdoms of Central Java), such that what happens to one part affects the others as well. For example, on the day of the 1994 eruption, gale-force winds struck the other ancient capital city of Central Java, Solo, some 30 kilometres east of Yogyakarta. A ritual expert in Solo asserted that this event was linked to the eruption of Merapi (Suara Merdeka 24/11/94a).

Some ritual experts claimed to see even wider linkages to the 1994 eruption of Merapi. An earlier-cited ritual expert in Jakarta claimed that Merapi was spiritually linked to an anak (child) volcano in Cuba, and that because of this linkage, when Merapi erupted in 1994 so did the volcano in Cuba (Suara Merdeka 24/11/94a). ${ }^{20}$ The same editorial also invoked, albeit negatively, global science and technology, noting that as Merapi is one of the most closely studied volcanoes in the world and attracts many foreign experts, it was hard to understand why the eruption was not predicted. ${ }^{21}$ In some sense, the eruption of Merapi was seen to challenge not just Javanese but also modern society, which is consistent with the traditional Javanese view of Mount Merapi as literally the paku alam (spike at the centre of the universe). The most important perceived link between the eruption of Merapi in 1994 and the wider world was a causal and moral one. As the previously cited spiritual leader in Solo noted of natural disasters such as Merapi's eruption and the wind-storm in Solo: 
Tang terjadi sekarang ini, tidak berdiri sendiri. Tetapi berkait dengan peristiwa atau kondisi, dalam kerangka sebab akibat. (What is happening now, does not stand alone. Rather it is linked to [other] events and conditions, in the manner of cause and effect.)

(Suara Merdeka, 24/11/94a)

The eruption of Merapi was seen as the effect, in short, of some cause in wider society. Merapi is a good example of the way that marginal places may interrogate central places (Tsing 1993).

There is a Javanese custom of travelling to and fasting in marginal places, mountains, forests and beaches, for insight. Merapi is seen as such a place: a place where things become 'clear'. In a graphic articulation of this belief, the villagers of Turgo say that the water in the spirit palace of Merapi is like a mirror, and that if you look into it you can see your own intestines. Merapi's eruptions are thought to have a similar, revelatory character: ritual experts predicted that the 1994 eruption would lead to the exposure of 'collusion' among government officials (Suara Merdeka 24/11/94a). The revelatory character of Merapi makes it a source of moral judgement for the wider society. Ritual experts characterized the 1994 eruption as a pengadilan alam (judgement of nature): as a sign for people, especially in government, to abandon their corrupt ways (Suara Merdeka 24/11/94a). There is an explicit tradition in Javanese thought of looking to the margins for social justice. A leitmotif of the history of Java (and an image that was highly popular throughout the long reign of former President Suharto) is the story of the ratu adil (the just king), who comes from the forests and mountains to replace a corrupt lowland ruler. This is essentially a story about the political disintegration and reintegration of society, which exactly parallels the interpretation of volcanic hazard. This hazard challenges, but ultimately also reaffirms, the integrity of the individual, the community, the kingdom and the state.

The symbolic importance of the margin to the centre continually challenges central efforts at representation. The former New Order regime of Suharto was famous for the extraordinary lengths it went to control public discourse. These efforts, and also their limitations, are reflected in the coverage given to the 1994 eruption of Merapi. There was constant evidence of the failure of the state to forestall alternative interpretations of the eruption. For example, the publication of technical daily updates from the Vulcanology Service on every tremor and belch of Merapi was coupled with considerable discussion of folk knowledge from the villagers on Merapi's slopes. Several press accounts referred to the fact that the villagers relied on natural signs to forewarn them of eruptions, and there was some debate as to whether or not such signs were present prior to the 1994 eruption (Suara Merdeka 23/11/94; Suara Pembaruan 23/11/94). There was ubiquitous use in press accounts of the local Javanese terminology for the volcano: both for its spirit inhabitants and its eruptions. Thus the Javanese term for hot gas clouds, wedhus gembel ('Javanese goat', the whorls of whose coat are likened to the spiralling gas clouds), was widely used instead of or in addition to the Indonesian term, awan panas, or the international vulcanological terms. Even more dramatic was the 
juxtaposition in newspapers of the Vulcanology Service's latest briefing and interviews with ritual experts' interpretations regarding the millenarian implications of these events. Many media accounts presented two different discourses in parallel, the modern technocratic one of the state and the traditional spiritual one of vernacular society. Indeed, some players, including high government officials, even participated in both discourses.

The starting point for this analysis, the interpretation of volcanic hazard as a threat to identity, concerns the crossing and destabilization of important social and epistemological boundaries. A challenge to orthodox fault lines also characterizes the wider public discourse of volcanic hazard. References in public interviews and analyses to Cuban volcanoes, and even napalm in Vietnam, are dramatic examples of this (as was a request to the author by the Turgo headman for 'safety bunkers' (bunker penyelamat) - since built - like those he saw in television coverage of the 1991 Gulf War). ${ }^{22}$ These juxtapositions of disparate elements are reminiscent of those that Bruno Latour (1993) cites as characteristic of the conditions of modernity. Following Latour, it is the very mixture of local and non-local, traditional and nontraditional elements in the stories about Merapi that defines their modernity and their meaning (Keeler 1988:94).

The hybridity of modern life cannot adequately be comprehended when our gaze is bounded by orthodox categories of time and place. It is in part the ability of a political ecological perspective to break or cross categories that makes this comprehension possible. One of the major legacies of Brookfield's work, 'unrepentant pre-modern' though he claims to be, has been to provide new tools for the study of modernity. The scope of such study is exemplified in the eruption coverage of the NGO newsletter Gunungan, which constructed biting political commentary precisely by its adroit movement back and forth between otherwise distinct discourses. It linked spirit and everyday worlds in its reference to disappearing funds, it linked natural and human disaster in its reference to 'mental degenerates in government', and it linked natural and bureaucratic hazards in its reference to 'burned spirits'. Like the lost villagers who cross into the spirit palace of Merapi, Gunungan crossed and thereby problematized the accepted boundaries to reality. Its purpose was to make the familiar and accepted less so, to make government policy look less like rice cakes and more like rocks - which is also the object, in part, of Brookfield's political ecology.

\section{Notes}

1 Field research was initially carried out on Mount Merapi between 1982 and 1985, with support from the Rockefeller and Ford Foundations, the East-West Center, and the Indonesian Central Planning Ministry, the United Nations Development Programme, the Yale Center for International Studies and Gadjah Mada University. Much of the research was undertaken in collaboration with Bambang Hudayana at Gadjah Mada University.

2 Blaikie and Brookfield wrote (1987:19) 'The approach of regional political ecology makes considerable use of various models and ideas surrounding the concept of the margin and marginality'. This interest in marginality has been further developed by 


\section{Michael R. Dove}

scholars working within or influenced by the field of political ecology, as exemplified in the work of Anna Tsing (1993).

3 In part as a consequence of the 1994 eruption, the agricultural system of Turgo has since shifted to a market-oriented system of grass growing and livestock raising, supplemented by cultivation and sale of perennial crops, especially fuelwood and various fruits. Market purchase of rice now takes the place of the subsistence cultivation of maize and tubers.

4 Scholars have looked at the relationship between the geography of volcanic-enriched soils on Java and human settlement (e.g. Geertz 1971; Mohr 1938), the soil fertility of specific locales in the aftermath of particular eruptions (see de Jong Boers 1995 on the impact of the 1815 Tambora eruption on soil fertility) and plant succession on lands affected by volcanic activities (e.g. the reforestation of Krakatau following its famous 1883 eruption). But there have been very few efforts to examine the way that volcanicrelated changes in vegetative cover affect agroecology. An exception is Blong's (1982) study of the way that some highland Papua New Guinea groups have adapted their agriculture (as well as culture) to frequent ash falls.

5 The everyday banality of life in the spirit world of Merapi even includes such modern bureaucratic activities as a census. Turgo villagers assert that so many dead have been called to Merapi that they had to have a catahijiwa (census).

6 A prominent ritual expert in Yogyakarta told the national press that the palace would function like a payung agung (royal umbrella) to protect Yogyakarta and environs from even greater eruptions in the future (Suara Merdeka 24/11/94a).

7 Keeler (1988: 100) makes a similar point in his analysis of government coverage of the total solar eclipse in Java in 1983: 'By means of language, the government embraced the eclipse, or attempted to embrace it, within its national project, and to make of it not a reflection upon the government, but yet another of that authority's many expressions.'

8 See the analysis by Harwell (2000a) of the linkage between Indonesia's internationally embarrassing fires in 1997-98 and its commitment to the development of remotesensing technology.

9 Laksono (1988) argues that mortality rates on Merapi, the volcanic hazards notwithstanding, compare favorably with the rates in the government's unhealthy transmigration sites.

10 The idealized linkage between volcanic disaster and resettlement is seen in the Social Services' pavilion observed by Pemberton (1994: 175) at the Solo court's 1982 Sekaten celebration: 'Near the pavilion's exit door stood a papier-mâché volcano in a state of perpetual eruption and a tiny model community representing what the government would provide should volcanic catastrophe totally obliterate a village.'

11 The ability to erase a village in law but not fact reflects the fact that, as with resettlement programs elsewhere in Indonesia, the government's actual abilities to move populations about typically fall far short of its announced policies and programs (Harwell 2000b).

12 Some media accounts did acknowledge 'soil fertility' in discussing the villagers' reluctance to transmigrate, but just as often they simply cited the fact that the villagers had lived there for generations (turun-menurun) (e.g. Dinamika Berita, 27/11/94; Kedaulatan Rakyat 8/12/94).

13 As a newspaper article noted in the wake of the 1994 eruption, natural disasters as well as illness and social unrest are all reminders from God (Suara Merdeka 24/11/94a). Adas traces this interpretation throughout Southeast Asia but suggests that it is strengthened in Java by its history and culture: 'The assimilation and transmutation of HinduBuddhist concepts produced a heightened sensitivity among the Javanese to stability and tranquility and the disruptive effects of change. It also resulted in a time sense that was based on a belief in the repeated and cyclic creation, decline, and destruction of the universe' (Adas 1979: 97-98).

14 Wisner (1993: 137n11) has compiled an impressive list of contemporary governments that have fallen as the direct result of natural disasters (de Boer, Zeilinga, and Sanders (2002) on the 'far-reaching' impacts of volcanic eruptions). 
15 The linkage between natural calamity and millenarianism has been noted in Java by Adas (1979), Carey (1974) and Moertono (1968).

16 These beliefs were anathema to the Indonesian government; see Pemberton's comment (1994: 187) on the difference between Suharto's regime and the Solo court over the latter's prophesied end: 'While Kraton prophecy announced, in effect, "This will all end!” New Order "tradition" insisted on just the opposite: "This can’t end; it must go on!" ... Kraton prophecy is perfectly capable of recognizing that one's days may be numbered, of foreseeing an end; New Order "tradition", by definition, is not'.

17 Anderson (1990: 35) wrote that 'The signs of a lessening in the tautness of a ruler's power and of a diffusion of his strength are seen equally in manifestations of disorder in the natural world - floods, eruptions, and plagues - and in inappropriate modes of social behavior - theft, greed, and murder.'

18 The association of moral breakdown with the renewal of society, personified by the coming of the ratu adil, is an ancient theme in Javanese society (Kartodirdjo 1984). As Adas (1979: 140) wrote in his analysis of Dipanagara's revolt against the Dutch in the nineteenth century: 'The rampant corruption of those in positions of authority, the debasement of highly revered customs and relationships, and the unchecked depredations of robber bands - all were closely linked in the Javanese prophetic tradition with the period before the coming of the Ratu Adil.'

19 At such times, even animals lose their identity. Moertono (1968: 74) cites the Javanese court chronicle, Babad Mataram, on the signs of the impending downfall of a city-state: '... animals of the forest have sought refuge in the city ... their sight has changed. Ngalengka [the capital city] is seen as a forest, and with great noise the animals entered the town, the birds give wailing cries; it is clear [that the city] will be destroyed.' This belief explains the great popularity of a story that circulated in the late 1970s about a leopard from the forests on Merapi that descended to the city of Yogyakarta and entered a classroom at Gadjah Mada University.

20 An editorial in one newspaper drew a more abstract connection to international debates about the inhumanity of man, suggesting that the condition of the victims of Merapi's gas cloud reminded us of the victims of US napalm bombs in Vietnam, which (as the editorial went on to add) was subsequently prohibited under the Geneva Convention (Suara Merdeka 24/11/94b).

21 The editorial continued its critique of modern technology by suggesting that tunnels that had been drilled into the mountain to lessen the chances of an explosive eruption might instead have allowed the gas cloud to escape the crater and surprise the villagers on the mountain's southern slope.

22 The most dramatic juxtapositions came from interviews with ritual experts. Tsing (1993), among others, has written of the special abilities of such people to problematize local/non-local divisions.

\section{References}

Adas, M (1979) Prophets of Rebellion: Millenarian Protest Against the European Colonial Order, Chapel Hill, NC: University of North Carolina Press.

Anderson, B (1972) The Idea of Power in Javanese Culture, in C Holt (ed.), Culture and Politics in Indonesia, Ithaca, NY: Cornell University Press, pp. 1-69.

(1990) Language and Power: Exploring Political Cultures in Indonesia, Ithaca, NY: Cornell University Press.

Blaikie, P and Brookfield, H (1987) Land Degradation and Society, London: Methuen.

Blong, R (1982) The Time of Darkness: Local Legends and Volcanic Reality in Papua New Guinea, Canberra: Australian National University Press.

De Boer, J, Zeilinga J and Sanders, D (2002) Volcanoes in Human History: The Far-Reaching Effects of Major Eruptions, Princeton, NJ: Princeton University Press. 
Boomgaard, P (1998) In the Shadow of Rice: Roots and Tubers in Indonesia, 1500-1950, Paper to Yale University Program in Agrarian Studies Colloquium, New Haven, CT, 6 March.

Brookfield, H and Byron, Y (1993) Southeast Asia's Environmental Future: The Search for Sustainability, Tokyo: United Nations Press.

Carey, P (1974) The Cultural Ecology of Early Nineteenth Century Fava, Singapore: Institute of Southeast Asian Studies.

Chester, D (1993) Volcanoes and Society, London: Edward Arnold.

Decker, R and Decker, B (1997) Volcanoes, New York: W. H. Freeman (3rd edn).

Dove, M (1985) The Agroecological Mythology of the Javanese, and the Political-Economy of Indonesia, Indonesia, 39, 1-36.

- (1986) The Practical Reason of Weeds in Indonesia: Peasant vs State Views of Imperata and Chromolaena, Human Ecology, 14, 163-90.

Geertz, C (1960) The Religion of Java, Chicago, IL: University of Chicago Press.

- (1971) Agricultural Involution: The Processes of Ecological Change in Indonesia, Berkeley, CA: University of California Press.

Gupta, A (1998) Postcolonial Developments: Agriculture in the Making of Modern India, Durham, NC: Duke University Press.

Harwell, E (2000a) Remote Sensibilities: Discourses of Technology and the Making of Indonesia's Natural Disaster, Development and Change, 31, 307-40.

- (2000b) The Un-natural History of Culture: Ethnicity, Tradition and Territorial Conflicts in West Kalimantan, 1800-1997, unpublished PhD thesis, School of Forestry and Environmental Studies, Yale University.

Hefner, R (1985) Hindu favanese: Tengger Tradition and Islam, Princeton, NJ: Princeton University Press.

Hewitt, K (ed.) (1983) Interpretations of Calamity From the Viewpoint of Human Ecology, Boston, MA: Allen and Unwin.

- (1997) Regions of Risk: A Geographical Introduction to Disasters, London: Longman.

Hudayana, B (1987) Tanaman dalam Usaha Tani Subsisten di Sebuah Desa Lahan Kering Lereng Merapi Yogyakarta (The Plants of the Subsistence Cultivation System of an Unirrigated Village on the Slopes of Merapi, Yogyakarta), Sarjana thesis, Anthropology Department, Gadjah Mada University.

De Jong Boers, B (1995) Mount Tambora in 1815: A Volcanic Eruption and its Aftermath, Indonesia, 60, 36-60.

Kartodirdjo, S (1984) Ratu Adil, Jakarta: Sinar Harapan.

Kates, R W and Burton, I (eds) (1986) Geography, Resources, and Environment, Volume I: Selected Writings of Gilbert F. White. Volume II: Themes from the Work of Gilbert F. White, Chicago, IL: University of Chicago Press.

Keeler, W (1988) Sharp Rays: Javanese Responses to a Solar Eclipse, Indonesia, 46, 91-101.

Laksono, P (1988) Perception of Volcanic Hazards: Villagers Versus Government Officials in Central Java, in M Dove (ed.), The Real and Imagined Role of Culture in Development, Honolulu, HI: University of Hawaii Press, pp. 183-200.

Latour, B (1993) We Have Never Been Modern (trans. Catherine Porter), Cambridge, MA: Harvard University Press.

Moertono, S (1968) State and Statecraft in Old Fava: A Study of the Later Mataram Period, 16th to 19th Century, Ithaca, NY: Modern Indonesia Project, Southeast Asia Program, Cornell University.

Mohr, E (1938) The Relation Between Soil and Population Density in the Netherlands East 
Indies, in Comptes Rendus du Congrés Internationale de Géographie Amsterdam 1938, 2 sect. IIIc, Leiden: Brill, pp. 478-93.

Pandey, U and Singh, J (1984) Energy-Flow Relationships between Agro- and Forest Ecosystems in Central Himalaya, Environmental Conservation, 11, 45-53.

Pemberton, J (1994) On the Subject of Java, Ithaca, NY: Cornell University Press.

Pranowo, H (1985) Manusia dan Hutan (Man and Forest), Yogyakarta: Gadjah Mada University Press.

Sherman, G (1980) What 'Green Desert'? The Ecology of Batak Grassland Farming, Indonesia, 29, 113-48.

Solway, J (1994) Drought as 'Revelatory Crisis': An Exploration of Shifting Entitlements and Hierarchies in the Kalahari, Botswana, Development and Change, 25, 471-98.

Triyoga, L (1991) Manusia Jawa dan Gunung Merapi: Persepsi dan Sistem Kepercayaanya (The Javanese People and Merapi Volcano: Perceptions and System of Belief), Yogyakarta: Gadjah Mada University Press.

Tsing, A (1993) In the Realm of the Diamond Queen: Marginality in an Out-of-the-Way Place, Princeton, NJ: Princeton University Press.

Waddell, E (1975) How the Enga Cope with Frost: Responses to Climatic Perturbations in the Central Highlands, Human Ecology, 3, 249-73.

Watts, M and Bohle, H (1993) Hunger, Famine and the Space of Vulnerability, Geofournal, 30, 117-25.

Wisner, B (1993) Disaster Vulnerability: Scale, Power and Daily Life, Geofournal, 30, $127-$ 40.

Zaman, M (1991) Social Structure and Process in Car Land Settlement in the BrahmaputraJamuna Floodplain, Man, 26, 673-90.

\section{Indonesian-language newspaper and magazine articles}

Dinamika Berita, 27/1 1/94, Menengok Kehidupan Anak di Barak Pengungsian.

Gunungan, 25/1/95, Geger Uang Merapi.

Fawa Pos, 24/11/94, 15 Mayat Dikubur Masal.

Kedaulatan Rakyat, 8/12/94, Pengungsi Pulang tak Izin, Dijemput Dandim Sleman.

Kedaulatan Rakyat, 9/12/94a, Kraton Tetap Lakukan Cara Labuhan di Merapi.

Kedaulatan Rakyat, 9/12/94b, Kualat, Kalau Membangon Villa di Daerah Terlarang.

Suara Merdeka, 23/1 1/94, Kaum Lelaki Belum Mau Mengungsi.

Suara Merdeka, 24/11/94a, Gembong: Akan Ada Bencana Besar.

Suara Merdeka, 24/11/94b, Tajuk Rencana: 'Kiai Petruk' Kembali Murka.

Suara Merdeka, 26/11/94, Takkan Ada Letusan Besar.

Suara Merdeka, 28/11/94, Probo Siap Pekerjakan Korban Merapi.

Suara Merdeka, 1/12/94, IB Sudjana Merasa Difitnah dengan Karikatur.

Suara Merdeka, 7/12/94, Kali Bebeng, Blongkeng, dan Krasak Banjir Lahar Dingin Gunung

Merapi.

Suara Merdeka, 8/12/94, Banjir Lahar Dingin di Kali Boyong.

Suara Merdeka, 9/12/94, Kegiatan Merapi dan Jumlah Korban.

Suara Merdeka, 11/12/94, Permadi SH.

Suara Pembaruan, 23/11/94, Kicau Burung Di Desa Turgo. 


\title{
3 Pacific island rural development
}

\section{Challenges and prospects in Kiribati}

\author{
Frank R. Thomas and Kautoa Tonganibeia
}

Despite the fact that the Pacific Island region is still predominantly rural, there is limited analysis of rural development problems and prospects, at least outside the grey literature (but see Brookfield 1979; Liew 1990; Overton and Scheyvens 1999; Thistlethwaite and Votaw 1992: 189-98; Ward and Proctor 1980). More generally, as the World Bank has noted: 'Rural development has been neglected for many reasons, but three stand out as critical: poor commitment and capacities in partner countries, waning international interest in rural issues, and poor commitment and weak performance in the Bank' (1997: 29). Much emphasis is instead directed at the process of urban growth and associated challenges. This bias is unfortunate, as many problems related to urbanization need to be understood within a context of rural poverty, which has resulted in the steady influx of migrants to district centres and island capitals. For most of the Pacific region, however, urban opportunities are limited and there is good reason to try to make rural areas more attractive for those who choose or are compelled to remain there.

For a geographically extensive and widely scattered nation such as Kiribati, consisting of atolls and lagoonless coral islands, a timid approach to development issues is one cause of uncontrolled urban growth. Urban expansion, largely confined to the southern portion of Tarawa atoll, cannot be sustained much longer in view of the limited capacity of the atoll environment to support further growth. There is an urgent need for donors, government and other interest groups to provide more assistance for relevant rural development initiatives, in part to stem the flow of internal migration to urban areas. Regional planning in Kiribati has long suffered from insufficient funding to decentralize government departments and agencies or to launch major commercial projects in rural areas. Development priorities have long been locked up in a cycle that gives precedence to the needs of urban residents, yet relative neglect of rural communities has exacerbated problems within urban settings. The Asian Development Bank (ADB) reported that some 50 per cent of the population in South Tarawa and 5 per cent in the outer islands are estimated to live below the basic poverty line (A $\$ 750$ per capita per annum in South Tarawa and $\mathbf{A} \$ 201$ per capita per annum in outer islands) (ADB 2002).

Despite major environmental limitations, some outer islands have potential for development of food production and marine resource harvesting, and thus income 
generation, while all could benefit from improved transport, water supply and sanitation, renewable energy, community skills and building of local institutions. Funding alone will not guarantee success of rural development schemes; local community involvement in designing and implementing projects is also necessary. In Kiribati, decision-making remains very much dominated by the top-down approach, with limited community involvement. Moreover, while some features of Kiribati social organization include household equality and consensus building, women and youths continue to face serious obstacles to their ability to fully participate in decisions about local community development, detracting from the effectiveness and sustainability of particular projects. The prevailing view among island communities is that they regard projects as belonging to the donors. This has led to rapid deterioration of physical capital in the difficult atoll environment. The process has encouraged an 'aid dependence' mentality, a legacy of paternalism under colonial rule, which dampens local initiative and encourages communities to wait for donor assistance. Capability on the islands is low, but there is little incentive to develop and change when outsiders make most of the key decisions.

Several themes examined here have wider applications and implications. At the regional level, it is a reminder that the idea of 'subsistence affluence' (Fisk 1982) among many Pacific rural communities, still cherished by some observers and used as a rationalization for a lack of urgency in tackling rural development problems, masks the deeper problem of poverty of opportunity, usually expressed by poor facilities, restricted access to services and limited livelihood opportunities (ADB 2002: 64). In the years leading up to independence in the late 1970s, a team of researchers, whose reports appeared in a series published by the Australian National University (Geddes et al. 1982), made recommendations for appropriate rural development in both Kiribati and neighbouring Tuvalu. The focus was on achieving development at the level of 'intermediate technology' suitable for local physical conditions, including the capacity of communities to pay for it, and consistent with culturally appropriate models reflecting people's education, motivation, organization and discipline. Yet, subsequent governments, while subscribing to the ideology of decentralization and expressing concern over the widening gap between rural and urban areas, achieved relatively little in shoring-up basic infrastructure and essential services, including the perennial difficulties of ensuring reliable transport. We argue that without serious implementation of the goals of decentralization, 'intermediate technology' may be insufficient to alter people's views that urban migration and the prospect of wage employment offer the best framework of achieving self-reliance and independence. However, the actual task of decentralization is exceptionally difficult and increasingly hindered by a persistent urban bias.

\section{Resources and constraints}

Kiribati consists of thirty-three atolls and reef islands, and includes the Gilbert, Line and Phoenix groups, which are spread over an area exceeding 5 million square kilometres of ocean straddling the equator, yet the total land area only 
slightly exceeds 800 square kilometres (Figure 3.1). Most of the Gilbert Islands and several of the Line and Phoenix Islands are located in the dry belt of the equatorial oceanic climatic zone. Prolonged droughts are common in most areas. The highly alkaline and coarse-textured, coral-derived soils of Kiribati are among the poorest in the world. They are typically shallow, with very low water-holding capacity, little organic matter and low availability of macro- and micronutrients apart from calcium, sodium and magnesium (Thomas 2003b).

Because of their small size and low elevation and the porosity of the coral bedrock, there is no surface water on these islands; rainfall soaks through the porous surface soil, creating a lens of slightly brackish freshwater. Unchecked urbanization and population growth on South Tarawa have resulted in sewage seeping into the groundwater in several areas. Of concern for the future of human settlement, affecting access to safe drinking water and agricultural production, is the threat of global warming and associated sea-level rise; no part of the country is more than 3 metres above sea level (Connell and Lea 1992). However, while Kiribati suffers from relative isolation, geographic fragmentation and land scarcity, it is well-endowed in marine resources, particularly those located in lagoon and reef environments of several of the outer islands, owing to their proximity to the nutrient-rich equatorial upwelling zone.

The population of Kiribati, having reached close to 84,500 in 2000, is unevenly distributed with about 93 per cent living in the Gilberts Group. Increasingly close to half live on the islets of urbanized South Tarawa on some 16 square kilometres of land. Over the entire nation, the population density is 116 per square kilometre; however, South Tarawa has a density of over 2,330 per square kilometre, with more than 6,000 per square kilometre on Betio Islet. The average annual rate of natural population increase is 2.5 per cent, hence the population is expected to double in less than 30 years, and the population is young, with 40 per cent under 15 years and a median age of just 20 years (Ministry of Finance 2002). Considerable

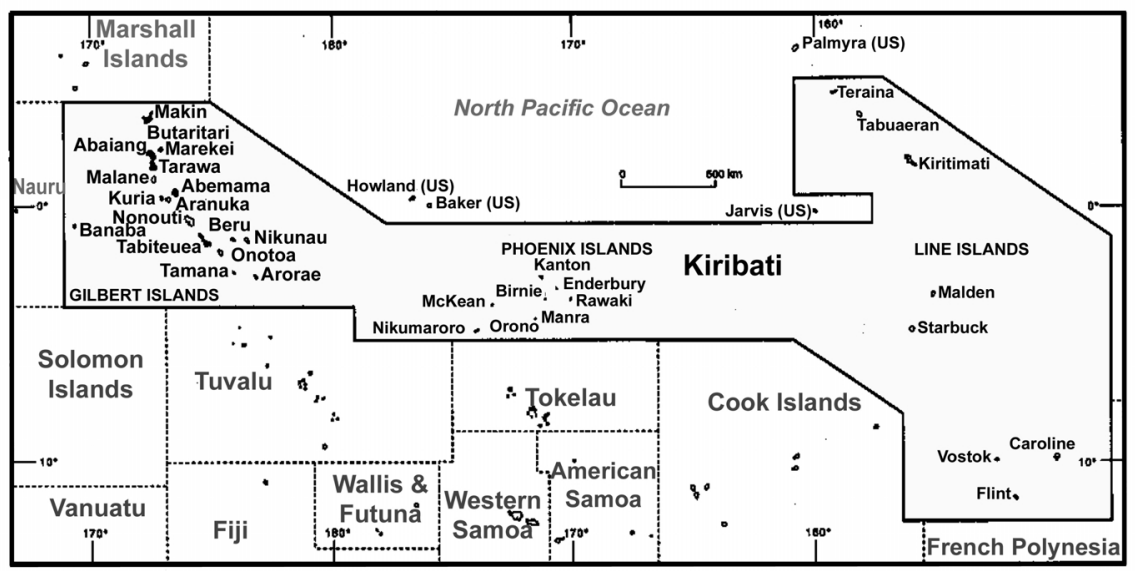

Figure 3.1 Kiribati. 
internal migration occurs from the outer islands to South Tarawa. A large portion of I-Kiribati (indigenous Gilbertese Micronesians) are supported by remittances sent by family members working in the phosphate mine on nearby Nauru and others who are engaged as merchant seamen. However, with the almost complete cessation of phosphate mining and advances in marine technology, remittances will probably diminish, with return migrants increasing pressure on local resources (Macdonald 1998: 62). There are few options for overseas migration because Kiribati has severed ties with the United Kingdom, although seasonal workers are currently admitted into New Zealand in limited numbers.

In recent years, overcrowding, notably on South Tarawa, has periodically resulted in serious health problems, particularly caused by contamination of freshwater supplies. To partly alleviate population pressure, in 1983 the government purchased the islands of Tabuaeran and Teraina in the Northern Line Islands from Burns Philp Islands Plantations for resettlement. The first trans-shipment of voluntary migrants from the Gilberts arrived in 1988. While these islands are attractive because of their high rainfall, and thus ability to support subsistence living, they are isolated from Tarawa and significant markets. Kiritimati has attracted wealthy sports fishermen for some years, but unreliable flight schedules have lost Kiribati many valuable tourists. Unlike the resettlement scheme to the Phoenix Islands between 1938 and 1963, which failed because of drought and isolation, the Northern Line Islands have the potential to develop both agricultural and fisheries production, provided that foreign fishing boats are forced to curb their activities and the settler numbers are kept within reasonable limits.

The Northern Line Islands supported close to 6,300 people in 2000, with more than half that number living on Kiritimati (Ministry of Finance 2002). It was estimated that the remaining atolls of Tabuaeran (Fanning) and Teraina (Washington) could absorb 5,700 settlers over a 10-year period, beginning in 1988 (Langston 1993). However, with 43 per cent of I-Kiribati people living on South Tarawa, and with an urban growth rate of 2 per cent, there is currently no sign of abatement in rural-to-urban drift (Connell and Lea 2002). As long as services remain concentrated, people will move to South Tarawa, hoping to gain a better education (based on Western models), the most gifted or ambitious perhaps landing a job as a public servant, finding some casual work in the informal sector, or at least living close to relatives who are already employed. Thus, push factors, such as declining agricultural commodity prices (mainly copra), as well as pull factors, such as the prospect of cash employment, the availability of public services in town and the intrinsic excitement of urban life, are patterns that characterize the phenomenon of urban expansion in Tarawa. While there are different levels of motivation shaping migration, both internal and external to any household, and while people adopt migration as a livelihood strategy for a variety of material and non-material reasons, migration is very much 'development-induced'. In other words, it largely reflects uneven development. The effects of migration on rural poverty depend on how remittances and the losses and gains of human resources through outmigration are distributed across households, on production constraints facing different household groups and on expenditure linkages within the rural economy. 
Not only is urban growth putting pressure on inadequate facilities and access to land, it also weakens development of rural areas and jeopardizes the future of agricultural subsistence production. Although urban migrants maintain strong ties with outer island communities, they are constrained by unreliable transportation. Kiribati's outer islands differ little from other remote islands in the Pacific region in being marginalized in relative terms. The benefits of technological investments in transport clearly favour core areas to a much greater degree than the peripheries, making it difficult for outer islanders to market local produce (Brookfield 1980), especially when distances and costs are great and volumes are low.

\section{Economic development strategies}

As a microstate, Kiribati presents unique challenges to development planners. The country is constrained not only by limited size, but also by a host of other environmental and geographical factors, including remoteness, dispersion, vulnerability to drought and a highly limited internal market (Baaro 1993). It is classified by the United Nations as a Least Developed Country. Kiribati was granted independence in 1979, shortly after the British exhausted phosphate mining deposits on Banaba (Ocean Island). Since then, copra and fish remained the main source of foreign exchange earnings, but earnings from the former have fluctuated widely in recent years. Since independence, however, Kiribati has moved towards a MIRAB ('migration, remittances, aid and bureaucracy') structure of economic development by relying heavily on foreign aid and remittances by migrant workers, which together account for more than US\$7 million annually (Bertram 1999: 341). Seamen are trained specifically for overseas employment. Foreign aid is likely to continue, especially through Japanese and Australian financial assistance, including student and training opportunities, albeit with diminishing resources, as donors seek greater accountability. The public sector remains a significant employer, but it is unable to absorb a growing number of young people, many lacking appropriate training, education or experience.

While recognizing the challenges of scale for further economic expansion, successive governments have perceived marine resources development as a means of attaining greater economic independence. With its vast exclusive economic zone (EEZ), Kiribati has relied heavily on fishing royalties from East Asian countries; inadequate local infrastructure, capital or skills means Kiribati is unable to exploit its fisheries sector efficiently. Consequently, the MIRAB economy is extended and perpetuated, although fishing royalties, together with income from the Revenue Equalization Reserve Fund (RERF), a legacy of phosphate mining, and payments made by the Japanese Space Agency on Kiritimati, illustrate the positive side of a strategy which seeks to diversify rent opportunities. The RERF, together with the sale of fishing licences and remittances, make up almost half of Kiribati's national income (ADB 2002). Fisheries production exceeds that of local agriculture, apart from copra exports, because of environmental constraints affecting the latter, though there are good prospects for increasing and improving agricultural production. Together with the development of near-shore fisheries exports and 
aquaculture, agriculture could provide more opportunities for employment while reducing dependency on food imports. Marketing, in both the agricultural and fisheries sectors, has proven to be the most difficult task for rural communities to organize (Lawrence 1989), because of acute transportation problems.

\section{Agriculture}

As a result of restricted land area, distance from continents, the relatively young geological age of the atolls and reef islands and the harsh environmental conditions, there are only about eighty-three indigenous plant species in Kiribati. Despite, or rather because of, the limited potential for agriculture, traditional cultivation techniques on the atolls exhibited a high degree of sophistication. A tree-cropbased multi-story farming system - arboriculture - is a distinguishing characteristic of the earliest agriculture in the Pacific Islands and is still a prominent feature of the Kiribati landscape, even in urban settings. Agroforestry constitutes a sustainable system of food production by virtue of the relative permanence of land use, and provides a wide range of subsistence needs, with crops receiving little direct cultivation beyond occasional mulching and replanting.

Agriculture has a significant role to play in the local economy through the achievement of increased copra production. In 1998, some 7,577 tonnes of copra were exported, worth $\mathrm{A} \$ 4.5$ million, compared with fish exports with a value of A $\$ 1$ million (Ministry of Finance 1998). One of the main extension programs of the Agriculture Division of the Ministry of Natural Resources Development (MNRD) in the outer islands is the improvement of copra production through replanting and rehabilitation. However, this scheme is constrained by land tenure, notably where land titles have yet to be legally transferred or where caretakers lack the interest to develop lands that belong to absentee landowners (Agriculture Division 2000). The Food and Agriculture Organization (FAO) has emphasized the need for small island states to develop a more intensified, diversified and sustainable agriculture. At the same time, it has recognized several challenges that stand in the way of achieving these goals, including inadequate infrastructure, a shortage of labour, poor quality and availability of planting material, a lack of efficient pest control and monitoring programmes, post-harvest losses, poor animal health, high costs of purchased feed and chemical inputs and weaknesses in both domestic and export marketing (FAO 1999). The natural environment in Kiribati compounds many of these problems, and thus further restricts the possible avenues for development of agriculture to ensure both food security at the subsistence level and greater financial benefits deriving from the export of a wider range of crops. Moreover, three very basic sets of difficulties face agricultural development on the outer islands: a shortage of staff, the lack of basic tools for farmers and poor communication links between the outer islands and the South Tarawa market, which affect the transport of copra and other goods (Agriculture Division 2000).

Although mixed subsistence/cash cropping of exotic fruits and vegetables on South Tarawa is mainly confined to Bonriki village (in large part because of the relatively extensive land area and low population density - by Tarawa standards), 
it demonstrates that, with some effort and organization, atoll communities need not depend solely on food imports (Table 3.1) (Thomas 2002). Yet Bonriki is exceptional in its semi-urban location. On the outer islands, including the string of islets no more distant than rural North Tarawa, the main disincentive for the expansion of gardening is the lack of reliable and efficient transportation to allow farmers to carry any surplus to urban markets.

As well as poor soil, drought can also be a major disincentive to agriculture. Lawrence (1989) also identified weak commitment among Tamana islanders to pursue gardening, citing the lack of free seeds, which had previously been supplied by the local Agricultural Assistant, while dependence on government subsidies prevented farmers from purchasing their own planting materials, even if they were available. Local food production alone, including the intensification of traditional agroforestry, will never be capable of supporting current population numbers. Moreover, cultural barriers, such as the continued perception among I-Kiribati that green leaves, papayas and other introduced foods rich in vitamin A should be fed to pigs or consumed only in the event of famine, discourage innovation. Livestock production in rural areas consists mainly of pigs, although chicken eggs, together with piglets, chickens and stock feed, are mostly sold on Tarawa and Kiritimati. Efforts are underway to improve pigs and chickens by cross-breeding introduced and local varieties, but the future of livestock expansion is limited because of the lack of sufficient space and restricted availability of food supply.

Officially, the Agriculture Division remains committed to improving transport, disease and pest control and marketing skills for farmers intent on supplying the domestic market (Government of Kiribati 2000), although the government admits that insufficient financial resources will further delay plans for development. Agricultural goods are normally transported by air to ensure freshness. Other products, namely fish and shellfish, are sun-dried, smoked or salted before shipment, and thus can be stockpiled on Tarawa (Figure 3.2), though there is a growing demand for local products on the domestic market.

Table 3.1 Crops planted by 20 households, South Tarawa

\begin{tabular}{lll}
\hline Crops (English name) & Scientific name & Frequency occurrence \\
\hline Chinese cabbage & Brassica chinensis & 20 \\
Pumpkin & Cucurbita pepo & 20 \\
Tomato & Lycopersicon esculentum & 17 \\
Watermelon & Citrullus vulgaris & 15 \\
Cucumber & Cucumis sativus & 13 \\
Rockmelon/canteloupe & Cucumis melo cantalupensis & 9 \\
Chilli & Capsicum frutescens & 8 \\
Eggplant & Solanum melongena & 4 \\
Bell pepper & Capsicum annuum & 4 \\
English cabbage & Brassica oleracea capitata & 3 \\
Swamp taro & Cyrtosperma chamissonis & 2 \\
Chinese broccoli & Brassica alboglabra & 1 \\
Hibiscus spinach & Hibiscus manihot & 1 \\
\hline
\end{tabular}




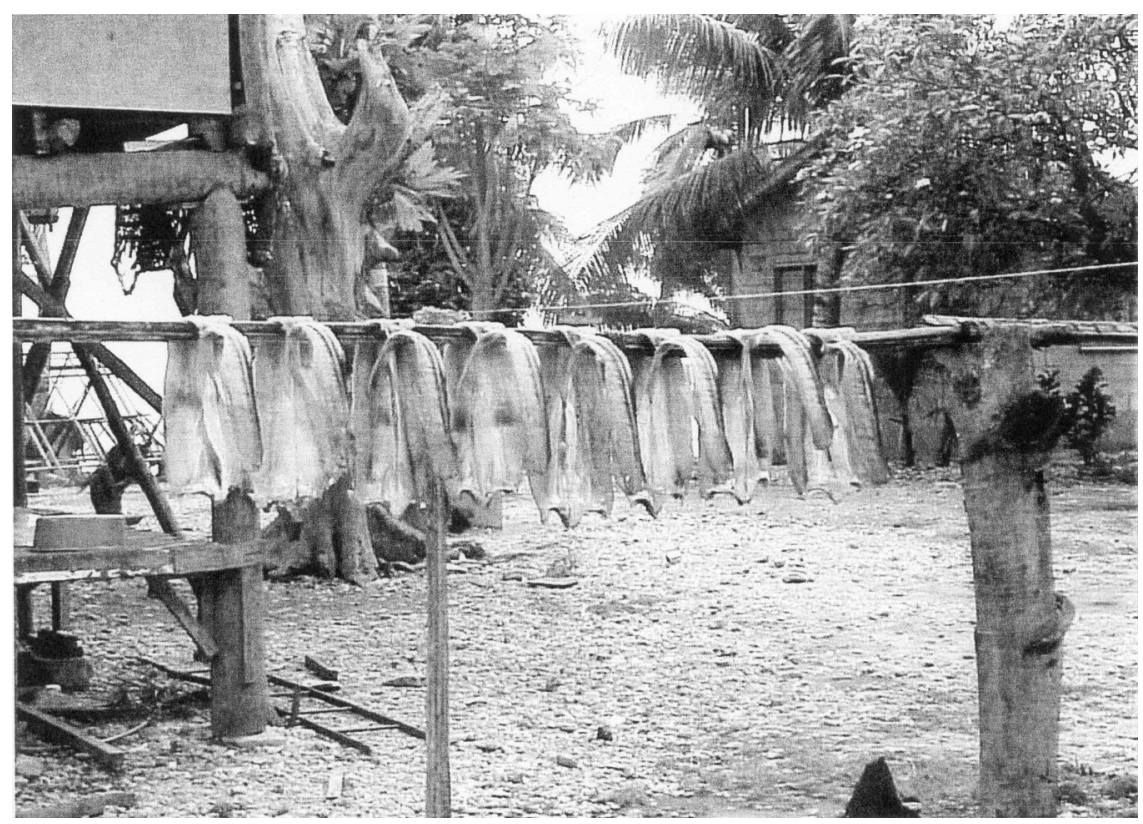

Figure 3.2 Drying fish, South Tarawa.

The fragility of Kiribati's atoll environment and its diminishing capacity to provide for the needs of an expanding population highlight the importance of judicious development of natural resources, both land-based and marine, and the urgent need to improve social infrastructure. Women are a pivotal element in both these areas - as resource users, household managers and custodians of the family and the integration of their needs and concerns into the process of policy design and implementation is critical to the success of national development strategies. Although women were traditionally able to inherit and own land within the collective family-based land tenure system, their rights were commonly inferior to those male family members, especially the eldest male, in whom control over the family land was vested. The gender-discriminatory features of the traditional system have been reproduced, and arguably strengthened, by the colonial policy of individual land titles (Emberson-Bain 1995). Excluding effectively half the population from rural development initiatives has weakened the chance of success.

\section{Fisheries and aquaculture}

Fishing is prominent in the lives of most I-Kiribati, both urban and rural. Annual per capita fish consumption is estimated at around 185 kilograms, among the highest in the world (Gillett and Lightfoot 2001: 58). With an EEZ covering more than 3.5 million square kilometres - the second largest in the world - it is not surprising that the fisheries sector is seen as both a source of essential livelihood at 
the subsistence level and as a means of generating revenue by promoting the country's seemingly vast store of marine resources.

Licensing of fishing vessels belonging to distant water fishing nations (DWFNs) contributes highly variable returns, which are largely affected by global weather conditions, notably El Niño and its reverse, La Niña. Licence revenues fell from A $\$ 40.3$ million in 1998 , as the impact of El Niño was felt, to $\mathbf{A} \$ 31.8$ million in 1999 during La Niña and $\mathrm{A} \$ 17.2$ million in 2000 (Government of Kiribati 2000). The main species taken are migratory skipjack and yellowfin tuna. Kiribati lacks adequate onshore facilities to attract higher levels of tuna trans-shipment by foreign vessels, but is seeking ways to develop its local fishing industry. To achieve this goal, obstacles need to be surmounted, such as the cost and availability of fuel, distance to markets and competition against efficient, capital intensive DWFNs, but these basic problems have persisted for a quarter of a century. The exploitation of Kiribati's EEZ for national development highlights the need for improved technology, skills, information and financial resources - an improbable combination in such a small island state.

In contrast to agricultural production, near-shore fisheries throughout Kiribati are vigorously pursued. Marine exports increased slightly in the 1990s, particularly of exotic species, notably aquarium fish, which have significant Asian markets. Improved storage facilities and transport between the outer islands and Tarawa would create incentives for artisanal fishers to sell greater volumes, yet at the same time there is a risk of overfishing, evident in the heavily fished Tarawa Lagoon, where population pressure and modern fishing gear have resulted in the serious decline of various resources, including some shellfish, bêches-de-mer and certain reef fish (Beets 2001). Heavy reliance on near-shore fisheries creates an urgent need for communities to manage their natural resources properly through customary marine tenure (CMT) systems (Thomas 2001; 2003a). The ability of CMT holders to police their tenured waters may indeed prove useful for both fisheries and aquaculture. Unfortunately for Kiribati, CMT has rapidly declined since Western contact. Though some island councils have adopted by-laws to protect fish and invertebrates, the greatest challenge is enforcing these laws. Lack of chiefly authority (unlike other Pacific island communities, where CMT has persisted, albeit with some modifications, partly because of more centralized community controls), together with weak traditional sanctions, contributes to difficulties in establishing effective marine tenurial systems. Proper resource management is crucial. Alternative projects for rural communities to generate cash, while allowing resources to recover, may hold the key to effective management, but opportunities are few.

Fishing can be highly lucrative for households with sufficient capital and labour. On South Tarawa, families equipped with boats, several nets and fishing lines, as well as insulated cooler boxes, can earn anywhere between $\mathrm{A} \$ 200$ and $\mathrm{A} \$ 700$ per week, which is considerably more than farmers can earn selling their produce, estimated at between $\mathrm{A} \$ 30$ and $\mathrm{A} \$ 100$ per week (Thomas 2002). The fisheries sector provides some of the best opportunities for raising incomes and, if properly managed, could form the basis for sustainable activities. Ironically, as in agricul- 
ture, many of the best opportunities are on Tarawa, simply because of access to markets.

As levelling off in fisheries production is anticipated, and with no foreseeable check in population, a future shortfall in the supply of fish may occur. Aquaculture is one means of filling this shortfall, avoiding costly imports and enhancing fisheries production by ensuring supply of baitfish, such as cultured milkfish (Chanos chanos), for the offshore tuna fishery (Government of Kiribati 2000). Once again, ironically, the two main commercial fishponds are located on Tarawa.

Aquaculture can assist in ensuring food security, replenish or enhance natural stocks of economically important resources, provide employment for potentially lucrative export markets and alleviate poverty by supplying low-cost fish for rural and urban consumers. Although aquaculture is one industry that can be taken to the region's scattered population, as has been demonstrated by pearl farming in the Cook Islands and seaweed farming in Fiji, its potential is yet to be realized in Kiribati.

Since its inception in the mid-1980s, seaweed farming in Kiribati has been successful in attracting a fair number of outer island producers who would otherwise have confined their cash-earning activities to copra production. Commercial production of Eucheuma seaweed on a smallholder basis began on six of the Gilbert Group of islands, but only Abaiang and Tabuaeran in the Line Group have emerged as major producers. In the early 1990s, some 2,000 smallholders, or nearly half the population of Abaiang, were growing seaweed (Tikai 1993). Overall seaweed production in the Gilberts has declined significantly, however, from a high of 1,019 tonnes in 1991 to a mere 12.2 tonnes in 2001. The increasing frequency of westerly winds associated with El Niño has discouraged many households from investing further in an activity considered high risk in an essentially risk-averse subsistence environment (Neemia-Mackenzie 1998). Without more weather-resistant varieties of seaweed and better monitoring of suitable growing sites, future success is unlikely. Even so, seaweed farming can contribute substantially more income to smallholders than copra production. While seaweed is primarily regarded as an export crop, there is potential for including it in the local diet, particularly in efforts aimed at reversing the effects of vitamin $\mathrm{A}$ and other vitamin and micronutrient deficiency problems. However, like green vegetables, marine plants are still generally avoided for cultural reasons.

The production of black pearls, derived from the black-lipped pearl oyster (Pinctada margaritifera), is one of the most recent aquaculture projects to emerge in Kiribati, following the success of cultured black pearl in the Tuamotus (French Polynesia) and the Cook Islands. By mid-2004, commercial production of pearls had commenced on Abaiang. The attraction of black pearls, while relieving pressure on overcrowded South Tarawa by encouraging back migration to some outer islands, could generate a new set of problems, since all Kiribati citizens have the right to exploit near-shore resources. Because of strong kinship ties, it would be easy for many individuals to identify relatives on the outer islands and thus lay claim to future black pearl concessions. Thus far, experimental projects on Abaiang atoll have yet to yield real successes. 
Exploitation of giant clams (Tridacnidae) to satisfy domestic consumption has led to the virtual demise of the largest species (Tridacna gigas) around Tarawa while stocks on the outer islands are low. Increasing coastal populations, pollution and improved harvesting efficiency were some of the factors responsible for the collapse, and in some cases extinction, of local stocks (Dawson 1998). Plans to raise giant clams for seeding on the outer islands and for restocking some areas of Tarawa lagoon adjacent to reefs and away from dense human settlement were discontinued because of lack of funding. Because of endemic pilferage in populated areas, traditional giant clam farming is currently confined to relatively isolated areas, such as sparsely inhabited islets. These clam 'gardens' are disappearing from the Kiribati seascape, in large part due to the decline of CMT. Owners are now less inclined to continue to care for giant clams in designated lagoon sections or invest in maintaining large fish traps.

\section{Non-farm rural livelihoods}

Even when compared with agriculture and fisheries, the promotion of non-farm activities in rural areas has been rather slow, whether of rural-based industries and tourist ventures, or handicrafts and various artisanal activities. For the small and scattered islands of Kiribati, limited opportunities exist for the development of nonfarm rural livelihoods. However, because fisheries, including aquaculture, have received more attention there is a possibility of developing linkage industries tied to local processing, such as fish canning, smoking and freezing. Of particular relevance to Kiribati is the possibility of setting up local processing centres for the emerging pearl industry. Such possibilities all lie in the future.

Tourism, especially ecotourism, has attracted some level of investment to areas that had previously been neglected. Ecotourism has been heralded by many as the saviour of the world's natural environments and a source of valuable income in remote places, and it has received much attention recently. Yet, despite the promise, there are a number of potential pitfalls. As well as the inevitable environmental impacts, there are parallel social impacts. Although ecotourists may be sensitive to environmental issues, visitors have an environmental impact. The attractions of Kiribati atolls, such as of Caroline Island in the Line islands, renamed Millennium Island, may in the not too distant future lead to an influx of cruise ship visitors to this remote part of Kiribati. Millennium Island supports no permanent population; its major attractions, which include underwater scenery and bird life, could be easily disrupted by even small groups of people. The same is true for some of the other islands in the Phoenix and Line Groups, particularly on Kiritimati, where regular flights (to the former) and occasional cruise ships now bring a steady stream of visitors, whose interests include sports fishing and bird watching. Second World War sites may attract others. Yet a fundamental issue is control of tourism and the returns to local people. While several of the outer islands, including North Tarawa, offer potentially attractive sites for visitors, cross-sectoral constraints exist to further development, including adequate air access, and road, water and power 
infrastructure, requiring close inter-agency and interdepartmental cooperation (Government of Kiribati 2000).

Non-agricultural activities in rural areas should increase as the level of education is raised and as productive infrastructure services expand, although because rural incomes are much lower than in urban areas, cost recovery of private sector involvement may be difficult to achieve in rural areas. On the outer islands of Kiribati the physical lack of cash is a major constraint to private enterprise development. Cash shortages occur because banking services are poorly developed and wholesalers and retailers operating from visiting boats remove cash to remit to Tarawa. Cash payments to copra cutters are often late, thereby delaying the replenishment of cash holdings. As Lawrence (1989) and other observers have noted, few I-Kiribati aim to earn a set level of income over a particular time period. Rather, they respond to immediate needs for cash as they arise. Development of income-generating activities - even stores - depends on a greater degree of cash availability. Secondary schools have been in existence on some outer islands for some time, reducing the need for students to move to Tarawa for education. However, facilities are often inadequate, and efforts to increase access to education in rural areas will do little to stem migration to Tarawa unless more job opportunities are created locally and the curriculum puts more emphasis on the household value of pursuing rural activities and on their relevance to broader issues of national development. As long as sharp inequalities between rural and urban life exist, outer island communities will continue to invest in education as a means of facilitating migration (Lawrence 1985), and value 'modern' rather than 'appropriate' education. Investment in transport and in forward-linkage industry using local products would benefit Kiribati. Bayliss-Smith et al. (1988: 276) have indicated that economic development requires the removal of institutional constraints, the introduction of new technologies and a greater degree of regional cooperation in addressing problems of transport and development. Development also calls for structural diversification to enhance the mobility of factors of production in the economy as a whole, as well as increasing the range of opportunities for ordinary citizens (Brookfield 1975). Kiribati is poorly placed for any of these. Non-existent economies of scale discourage the kinds of investment that would make such developments possible.

\section{Towards sustainable rural development}

For generations, traditional management of resources in Kiribati ensured a plentiful supply of marine products for the indigenous population (Zann 1985). Today, changes in Kiribati lifestyle brought about by high rates of population growth, imbalance of population distribution and a move towards Western-inspired materialism are placing increasing demands on the environment and natural resources. In their attempts to gain greater economic independence, small island states such as Kiribati have little choice but to rely on economic growth based on natural resource exploitation rather than on the industrial sector. Agriculture and 
fisheries have been, and will remain, both the main economic activity and the main source of exports.

The desire to achieve a higher nutritional and health status can be translated into a policy of substituting, in part, locally produced food for imported foods. Food imports, particularly staples, play a very important role in meeting people's dietary needs, especially on South Tarawa. However, increasing local food production is desirable for improving nutritional standards and perhaps for generating revenue based on the export of specialist produce. Kiribati has fewer options as far as the agriculture sector is concerned than for fisheries, particularly regarding the range of export products. Marine resources development, if properly managed, should lead to greater economic independence, but without eliminating the MIRAB component. On Tarawa, where the population density is greatest, the utilization of the reef flats and lagoons will increase, leading to greater pressure on existing stocks. It will then not only be economically necessary to create successful aquaculture projects on the outer islands, but also crucial to stem or reverse migration to South Tarawa. If infrastructure, goods and services, including adequate healthcare, remain concentrated on Tarawa, most of the outer islands will remain unattractive places for those who are successful financially. With limited goods in island stores there will be little incentive to earn extra cash, a vicious circle that has long discouraged commercial development. Not surprisingly, outer-island stores, further away from the capital, invariably display bare shelves for longer periods of time because they are less frequently replenished by new shipments. Indeed, the real objective among rural dwellers may not be the maximization of income but the optimization of welfare. While individual entrepreneurs exist, many people opt to work in groups for much lower rates of return. They prefer the anonymity of collective effort and also the enjoyment of group participation. Social objectives may outweigh economic ones.

For some years social scientists have drawn attention to the counterproductive nature of the objective of achieving economic growth without taking into account local, culturally based interests. Thus the Tongan economist Sitiveni Halapua has criticized the concept of development itself and its relationship to increasing conflict and poverty in the Pacific Island region (Halapua 1997), where governments are primarily focused on increasing the production of goods and services, mainly for serving urban centres, by balancing income and expenditure but at the expense of balancing the right to use resources against the obligation to ensure their continuity.

The failure of development projects on atolls has largely resulted from the absence or lack of public consultation with, and involvement of, the project beneficiaries, poor project planning and implementation, lack of attention to environmental impact and the sustainability of the resource base, inadequate and inappropriate human resource development and local institution building, lack of integration with other sectoral activities, inappropriate choice of technology and lack of consideration given to socio-cultural dimensions (Liew 1990: 83). In short, in Kiribati as elsewhere, projects have too often been imposed from outside. A quarter of a century after independence, many discussions related to improved 
rural livelihoods have yet to find concrete expression, judging from the continued flow of people to urban areas. Shortly after independence Geddes et al. (1982: 155) proposed that in order to weaken trends towards a dual economy, urban living should be discouraged by reducing or eliminating subsidies and by taxing imports more heavily. In reality, however, these policies proved unpopular among existing urban residents. Politicians on Tarawa, as elsewhere, are well aware that such moves may cost them votes at election time. The urban population is now both large and powerful.

I-Kiribati living in rural areas, particularly on outer islands, remain disadvantaged by limited access to basic public services, and they have few cash earning or employment opportunities as a result of the distance to local markets, perennial transport difficulties and the lack of services. Moreover, certain interest groups have perhaps deliberately or unconsciously held back rural areas in the name of 'sustainability' or because of a reluctance to disrupt traditional lifestyles, but a nogrowth policy will not ensure poverty alleviation (Sachs 1999). I-Kiribati, like other Pacific Islanders, aspire to economic development, but if the rapidly increasing population is to find meaningful employment, income inequalities are to be narrowed and special attention is to be paid to the advancement of women, then rural economies will need to grow rapidly. Otherwise I-Kiribati will continue to seek material prosperity elsewhere, rather than accept aid-dependent pauperism back on the outer islands (Ward 1993). Knudson (1981) noted that, by independence, the economies of South Tarawa and the outer islands were already quite distinct and based on different resources. More than twenty years later the gap between the two areas has grown sharper with increasing monetization (ADB 2002: 52-53) despite frequent attempts to devise policies of rural development and decentralization.

Successive national development plans have unsuccessfully sought to redress the imbalance in the distribution of development benefits between South Tarawa and the outer islands. This imbalance continues because of the greater absorptive capacity of Tarawa, and because of problems of project implementation and absorptive capacity on the outer islands. Plans and policies have not been sustained with investment, or have collapsed through technological difficulties, environmental limitations, input failures and loss of initiative. From a community perspective, improvements were seen essentially in terms of a better living environment rather than as changes in the resource base and the emergence of new wealthgenerating opportunities (Lawrence 1989). Promoting development that is environmentally and culturally appropriate for small, remote islands and atolls will only be partly achieved by money, technological initiatives and community participation. What is equally important is a strong political will to implement decisions beneficial to rural areas. At the moment, as in other island states, this is absent since many who hold the reins of power are members of the urban elite who benefit from an urban lifestyle and need the support of urban voters. Moreover, global trends of urbanization augur poorly for proponents of rural development. Even if the political will fails in the foreseeable future, circumstances might eventually compel leaders and other urban dwellers to take a serious look at the need to achieve a 
balance between urban and rural areas. Aid and subsidies have limits, and sustainable urban living cannot be achieved without strong rural involvement.

\section{Conclusion}

Development strategies in Kiribati, as in several other small island states in the Pacific and elsewhere, incorporate limited options. Moreover, outer islanders are no longer, if they ever were, living under conditions of 'subsistence affluence'. Their links to the outside world and, most importantly, the growing disparity between urban and rural incomes and services encourage urban migration. But Tarawa offers only a partial remedy to the problems faced by rural migrants (compared with the few who travel overseas and settle in Pacific-rim metropolitan areas). Thus, issues of rural development urgently need to be addressed and must go further than political and economic rhetoric. However, because of the fragile nature of atoll environments, development planning should be geared towards maximum sustainability if the idea of 'development' is to have any meaning. Indeed, development must be configured to meet the specific needs of small island developing states endowed with limited natural resources and MIRAB options. There is no realistic alternative.

Nowhere else is it more critical than in the small and scattered atolls of Kiribati that environmental conservation be taken into account when planning for development. For example, increased use of solar energy, wind power and biogas would reduce the great cost of imported fossil fuels, improvements of rainwater catchments would ensure better water quality and reduce dependence on underground lenses, and efforts at reforestation would mitigate the effects of erosion and storm damage as well as encourage use of selected forestry products. Finally, the development of sustainable fisheries and agricultural activities must be compatible with the atoll environment to generate some foreign exchange earnings and improve nutrition.

The Northern Line Islands settlement scheme to alleviate population pressure and to provide more income opportunities, notably through aquaculture and tourism, is instructive. While these islands may provide a solution to some of Kiribati's development problems, they also highlight the need to closely monitor environmental impacts, especially those associated with overfishing, tourism and the Japanese Space Agency. Moreover, the cost of developing the Line Islands has only been achieved with considerable support from overseas aid.

On the basis of Kiribati experiences, the development debate in the Pacific Islands and beyond should emphasize sustainable income-generating activities in rural areas to reduce migration to urban centres, which are already strained in terms of infrastructure and employment opportunities. Yet, as time goes by, this objective grows more remote. More than twenty years ago, and on the eve of independence, the Australian National University team concluded that:

the economic prospects for the Gilbert Islands and Tuvalu are not promising. No new economic resource other than the sea is likely to present itself ... the 
islands' remoteness from markets will always create difficulties ... . The future appears to lie in maximizing returns from existing resources, the export of labour, import substituting, the careful control of government spending and, for the Gilberts, the development of the resources of the islands without indigenous population.

(Geddes et al. 1982: 5)

Even then, such policy prescriptions seemed both too late and somewhat improbable in the face of rising expectations. As Geddes et al. also concluded, 'considerable political skill will undoubtedly be needed to dampen down local expectations and aspirations that are no longer realistic' (1982: 187). That never happened; as elsewhere, politicians made promises that could never be met, and Kiribati scarcely developed beyond the poverty line (Connell 1985). Many I-Kiribati, as Lawrence (1989) reported, still respond to immediate cash needs, but delays in payment, especially for copra production, certainly act as a disincentive to the intensification and successful development of these activities. Moreover, outer islanders nowadays are increasingly drawn into the global economy, and an increasing number aspire to greater cash needs and immediate and longer-term access to goods and services that are still largely confined to urban Tarawa. Migration continues and further emphasizes urban bias, present even in the agricultural and fisheries sectors. As it currently stands, I-Kiribati may have little choice but to migrate. In some island states the challenges to development may be overwhelming.

\section{References}

Agriculture Division (2000) Annual Report, Tarawa: Ministry of Natural Resources Development.

Asian Development Bank (ADB)(2002) Kiribati: Monetization in an Atoll Society, Manila: Asian Development Bank.

Baaro, B (1993) Economic Overview, in H van Trease (ed.), Atoll Politics: The Republic of Kiribati, Suva: Institute of Pacific Studies, pp. 161-67.

Bayliss-Smith, T, Bedford, R, Brookfield, H and Latham, M (1988) Islands, Islanders and the World: The Colonial and Post-colonial Experience of Eastern Fiji, Cambridge: Cambridge University Press.

Beets, J (2001) Declines in Finfish resources in Tarawa Lagoon, Kiribati, Emphasize the Need for Increased Conservation Effort, Atoll Research Bulletin, 490, 1-14.

Bertram, G (1999) Economy, in M Rapaport (ed.), The Pacific Islands: Environment and Society, Honolulu, HI: Bess Press, pp. 337-52.

Brookfield, H (1975) Multum in Parvo: Questions about Diversity and Diversification in Small Island Developing Countries, in P Selwyn (ed.), Development Policy in Small Countries, London: Croom Helm, pp. 54-76.

- (1979) Land Reform, Efficiency and Rural Income Distribution, Pacific Viewopoint, 20, 33-52.

- (1980) The Transport Factor in Island Development, in R T Shand (ed.), The Island States of the Pacific and Indian Oceans: Anatomy of Development, Canberra: Australian National University, 201-38. 


\section{Frank $R$. Thomas and Kautoa Tonganibeia}

Connell, J (1985) Islands on the Poverty Line, Pacific Viewpoint, 26, 463-73.

— and Lea, J (1992) 'My Country will Not Be There': Global Warming, Development and the Planning Response in Small Island States, Cities, 9, 295-309.

- (2002) Urbanisation in the Island Pacific, London: Routledge.

Dawson, R (1998) Giant Clam Exploitation in the Southwest Pacific, in J Copland and J Lucas (eds), Giant Clam in Asia and the Pacific, Canberra: ACIAR, pp. 254-55.

Emberson-Bain, A (1995) Women in Development: Kiribati, Manila: Asian Development Bank.

Food and Agriculture Organization (FAO) (1999) Plan of Action on Agriculture in Small Island Developing States, Rome: FAO Council, 116th Session.

Fisk, E K (1982) Subsistence Affluence and Development Policy, Regional Development Dialogue Special Issue: Regional Development in Small Island Nation, 1-12.

Geddes, W H, Chambers, A, Sewell, B, Lawrence, R and Watters, R (1982) Islands on the Line: Team Report, Social Change in Kiribati and Tuvalu No. 1, Canberra: Australian National University.

Gillett, R and Lightfoot, C (2001) The Contribution of Fisheries to the Economies of Pacific Island Communities, Manila: Asian Development Bank.

Government of Kiribati (2000) National Development Strategies 2000-2003, Tarawa: Government of Kiribati.

Halapua, S (1997) Harmonising Resources for Sustainable Economic Development in the Pacific Islands Context, in B Burt and C Clerk (eds), Environment and Development in the Pacific Islands, Canberra: National Centre for Development Studies, Australian National University and University of Papua New Guinea Press, pp. 22-29.

Knudson, K (1981) Adaptational Persistence in the Gilbert Islands, in R W Force and B Bishop (eds), Persistence and Exchange, Honolulu, HI: Pacific Science Association, pp. 91-99.

Langston, P (1993) Northern Line Islands Development, in H van Trease (ed.), Atoll Politics: The Republic of Kiribati, Suva: Institute of Pacific Studies, pp. 200-211.

Lawrence, R (1985) Views from the Centre and the Periphery: Development Projects on Tamana, Southern Kiribati, Pacific Viewpoint, 26, 547-62.

- (1989) Tamana 'Impact Study', Wellington: Integrated Atoll Development Project, Victoria University of Wellington.

Liew, J (1990) Sustainable Development and Environmental Management of Atolls, in

W Beller, P d'Ayala and P Hein (eds), Sustainable Development and Environmental Management of Small Islands, Paris: UNESCO, pp. 77-86.

Macdonald, B (1998) Pacific Island Stakeholder Participation in Development: Kiribati, Washington DC: World Bank.

Ministry of Finance (1998) International Trade Statistics, Tarawa: Statistics Office, Ministry of Finance.

- (2002) Report on the 2000 Census of Population, Tarawa: Statistics Office, Ministry of Finance.

Neemia-Mackenzie, U (1998) Social and Cultural Factors in Seaweed Production in Kiribati, Lymington: MacAlister Elliott \& Partners.

Overton, J and Scheyvens, R (eds) (1999) Strategies for Sustainable Development: Experiences from the Pacific, London: Zed Books.

Sachs, I (1999) Social Sustainability and Whole Development: Exploring the Dimensions of Sustainable Development, in E Becker and T Jahn (eds), Sustainability and the Social Sciences, London: Zed Books, pp. 25-36.

Thistlethwaite, R and Votaw, G (1992) Environment and Development: A Pacific Island Perspective, Manila: Asian Development Bank. 
Thomas, F (2001) Remodeling Marine Tenure on the Atolls: A Case Study from Western Kiribati, Micronesia, Human Ecology, 29, 399-423.

- (2002) Self-reliance in Kiribati: Contrasting Views of Agricultural and Fisheries Production, Geographical Fournal, 168, 163-77.

- (2003a) 'Taming the Lagoon': Aquaculture Development and the Future of Customary Marine Tenure in Kiribati, Central Pacific, Geografiska Annaler B, 85 (4), 243-52.

- (2003b) Kiribati: 'Some Aspects of Human Ecology' Forty Years Later, Atoll Research Bulletin, 501, 1-40.

Tikai, T (1993) Fisheries development, in H van Trease (ed.), Atoll Politics. The Republic of Kiribati, Suva: Institute of Pacific Studies, pp. 168-89.

Ward, R G (1993) South Pacific Island Futures, The Contemporary Pacific, 5, 1-21.

- and Proctor, A (1980) South Pacific Agriculture: Choices and Constraints, Manila: Asian Development Bank.

World Bank (1997) If Rural Development Is So Important, Why Is It Not Happening?, in World Bank, Rural Development: from Vision to Action, Environmental and Socially Sustainable Development Studies Monograph Series No. 12, Washington DC: World Bank, pp. 29-39.

Zann, L (1985) Traditional Management and Conservation of Fisheries in Kiribati and Tuvalu Atolls, in K Ruddle and R E Johannes (eds), The Traditional Knowledge and Management of Coastal Systems in Asia and the Pacific, Jakarta: UNESCO/Regional Office for Science and Technology for Southeast Asia, pp. 53-77. 


\title{
4 Agricultural landscapes of Kadavu
}

\author{
Persistence and change on the \\ Fijian periphery
}

Robert Kuhlken

This chapter traces changes in cultivation practices and consequent agrarian landscapes in one of the more remote locations in the Fijian archipelago: Kadavu island. It illustrates diversity and persistence, but also change, within Pacific agrosystems, and addresses the opportunities and constraints of market commercialization. While a number of scholars have investigated society-nature relations in these islands, none have bridged disciplinary boundaries more adroitly and emphasized an applied bent than Harold Brookfield. Since the early 1970s his publications have attested to a concern for the environments, cultures and politicalecological processes of economic development within Fiji (Brookfield 1985, 1987, 1988; Brookfield and Hart 1971; Brookfield 1977). Additional theoretical contributions have informed the continuing debate over intensification in Pacific islands agriculture (Brookfield 1972, 1984, 2001a) and are of particular concern here.

Various cultivation methods, crop complexes and village-based agrosystems exist on Kadavu. There is a mixture of cash cropping and subsistence regimes, and the resultant land use pattern manifests a broad spectrum of production strategies. Various soil and water management techniques are practised, along a continuum of labour intensity, and traditional agricultural landforms are still in place. Garden plots usually include a number of different food plants at several stages of maturity. There is likewise a remarkable variety of cultivars, and agrodiversity is directly reflective of overall biodiversity (Thaman 1993). Beyond cultivation, wild and semi-domesticated fruit and nut trees are an important component of what might be viewed as a complementary gathering-horticulture medley. Swidden is still the most widespread method for growing the root crops that form the basis of village subsistence, although traditional cultigens such as taro and yams are now augmented and in some cases largely displaced by more recently introduced cassava. Intensification of root crop production, past and present, is readily apparent from the evidence indicating landscape modifications, including mounds, raised fields and irrigated terraces. Although many of these skilfully engineered gardens have been abandoned, a number of raised fields remain in use, while several terraced irrigation systems continue to function along the south coast. These remnants of once more-prevalent intensive horticultural systems are 
valuable guides for understanding both traditional cultural ecology and contemporary political ecology.

Kadavu is not only far removed from the global system, but it is also peripheral to much of Fiji, and its isolation from national markets and employment opportunities has much to do with overall agrodiversity as well as the persistence of traditional agricultural landforms. Moreover, Kadavu has always been one of the least known and visited islands in Fiji. Even the 1840 United States Exploring Expedition, which charted most of the reefs and shoals in Fiji, and surveyed nearly every coastline, largely excluded Kadavu (Wilkes 1845: 319). Nevertheless, past efforts at plantation agriculture have disrupted the established agrarian order, despite recurrent failure, while newer schemes for exporting specific commodities such as yaqona (kava: Piper methysticum) have required land and labour formerly used for growing food.

This chapter examines the transformation of former areas of intensive agriculture into lands devoted to cash cropping or to less encumbering dryland cultivation. Neglected vestiges of agricultural landforms, such as yam mounds, raised fields or formerly irrigated taro terraces, despite abandonment, can be viewed as landesque capital, representing much investment of time and labour (Blaikie and Brookfield 1987; Brookfield 2001b: 55). A focus on taro terraces elucidates one of the more successful, albeit increasingly unique, methods of boosting yields. Since irrigated terracing now makes up only a minor part of the subsistence landscape, the wider pattern of agriculture in which it takes place is first outlined to illustrate how this agronomic activity is embedded within the cultural matrix that serves to maintain its vitality.

\section{Kadavu}

One of some three hundred islands in Fiji, Kadavu, the fourth largest island, is 80 kilometres south of Viti Levu, the largest island, and roughly 55 kilometres in length, with an area of 420 square kilometres. Two narrow isthmuses geographically divide Kadavu into western, central and eastern portions. The island's convoluted shoreline has many deeply indented bays, while its mountainous spine is defined by the eroded stubs of fifteen volcanoes. Elevations for these highlands typically range from 150 to 400 metres, with the prominent volcanic dome of Nabukelevu (Giant Yam Mound) being the high point, at 805 metres (Figure 4.1). The island is well watered, with numerous streams running from the hills to the coast; as elsewhere in Fiji, periods of drought are not uncommon, though annual rainfall averages around 2,140 millimetres. Kadavu's 1986 population amounted to 9,805 people living in 72 coastal villages (Ratuvakacereivalu 1992, 82) composed of 2,146 households (Dinavuso 2002: 183).

Kadavu has long been considered a haven of traditional Fijian culture, resulting from its geographical isolation and independent social and political development. It was never a major player in the internecine wars and power struggles between the larger polities, known as matanitu, that raged for several centuries in the eastern parts of Fiji. Historical interactions with European incursions were mainly limited 


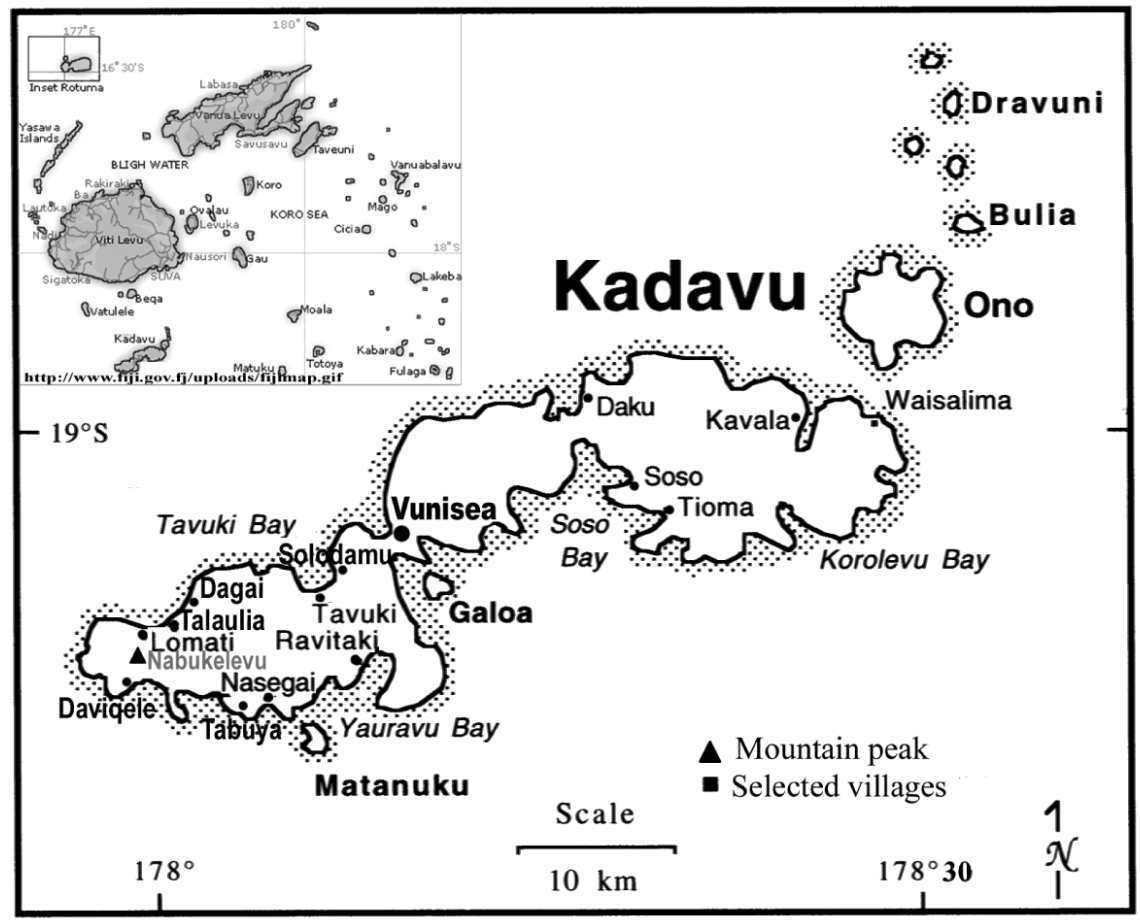

Figure 4.1 Kadavu, Fiji.

to the brief visits of whaling ships or bêche-de-mer (sea cucumber) collectors, and to short-lived and unsuccessful attempts at establishing plantation agriculture. In 1874 Fiji became a British colony, and agricultural traditions changed following the encouragement of export opportunities and the need to grow the commodities required for payment of taxes. Governor Arthur Gordon then wrote that Fijians 'are passionately fond of agriculture, but their cultivation, though very neat and careful, is chiefly that of food plantations and articles for domestic use' (quoted in Burns 1963: 117). To generate income for the colony, the governor established a program whereby each district would pay taxes through the sale of vegetable produce on the domestic or overseas market. This program listed specific items that the government would accept, and required every district to establish 'tax gardens' to grow only those items. Commodities varied between districts, but were mainly introduced commercial crops, never the traditional food plants of village-based agrosystems, and included cotton, coffee, maize, tobacco and sugar cane (Ward 1964: 487). Indigenous products, including copra, candlenuts and bêche-de-mer, were occasionally marketed from districts without significant plantation crops. Tax gardens became a ubiquitous feature of early colonial landscapes throughout Fiji and caused conflict with customary subsistence land and labour requirements, even on Kadavu. 
Transport around the island has always been difficult, and while a few short roads have been built, the overall situation today is similar to that reported by one of HMS Challenger's naturalists: 'There are no roads in the island of Kadavu, merely narrow tracks through the woods and along the shores, which are excessively tiring to traverse' (Moseley 1879: 261). Walking tracks link most villages, in some places crossing over the central hills, but many are now disused. Some villages, such as Daviqele, which rely on these tracks to access garden lands, still take pride in keeping them cared for, and they arrange periodic work parties to attend to cleaning and weeding the rights of way. But to travel long distances around the island, or to visit the administrative centre at Vunisea, where the ferry landing, airstrip, post office, government agencies and hospital are located, is a chore. Canoes were the obvious mode of transport in earlier times, and even 'nowadays nearly all travel is by boat' (Woodrow 1980: 1). But it is expensive for a village to own and maintain a 'fiber' - a runabout of fibreglass construction powered by an outboard motor - and the few operators who charter their services charge high fares. Ironically, Kadavu was once recognized throughout Fiji for the quality of its canoes and for making the large woven canoe sails (Hocart 1929; Tippett 1968).

Transport beyond Kadavu is likewise problematic, including inadequate transport connectivity with Viti Levu (Sofer 1985a: 133). Several private commercial ferries have operated over the years, with limited success, but a pair of vessels operated by the province make intermittent passages, and there are plans for upgrading port facilities at several places on the island (Dinavuso 2002). A tiny grass runway spanning the full width of the narrow isthmus at Vunisea serves as Kadavu's air transport facility. Two carriers (Air Fiji and Sunflower Airlines) schedule several flights a week from Suva and a weekly service from Nadi International Airport. Most passengers are tourists visiting the few small resorts on the island, which in the past tended to cater almost exclusively to divers. Recently, a number of low-key ecotourism resorts have been established, targeting a more diverse clientele intent on combining nature appreciation with a cultural experience. A quite new development is the subdivision of long-term leases for holiday residential use, such as at Waisalima Beach Resort and Dive Centre, an Australianoperated facility in eastern Kadavu, where several parcels in the thirty-lot Nukubalavu Estates have already been sold. The project's internet web page proclaims that buyers will be able to 'maximise the potential return on your investment, should you purchase a lot at Nukubalavu Estates by growing KAVA on the property for export!!' (Nukubalavu Estates 2003).

Apart from government or tourism jobs, Kadavu affords few opportunities for wage employment, resulting in two contrasting phenomena: a high degree of independence and continued reliance on gardening and fishing as subsistence activities, alongside frequent labour migration elsewhere in Fiji and beyond. Suva is the nation's primate city, and many kai Kadavu (Kadavu people) relocate there either on a temporary or semi-permanent basis. Lengthy sojourns on Viti Levu to visit relatives often result in transitory employment. For example, Lomati villagers have stayed with relatives outside Suva for several months while working in a garment factory, a continued possibility while Fiji's textile industries remain robust 
despite the country's economic stagnation (Connell and Lea 2002: 78). For this kind of labour circulation 'within Fiji, Kadavu was the area with the highest mobility' (Sofer 1992: 125) and Kadavu has been one of the Fijian regions displaying marked population losses following internal migration. Even earlier, Ward (1961: 261) reported that in 1956 Kadavu had the lowest percentage (54.0) of registered landowners still residing in their province. Migration may also be of longer duration and further afield; in one case, workers were employed for a full year on a forestry gang in New Zealand, continuing 'a long association between villagers from Kadavu and the work permit schemes' (Levick and Bedford 1988: 19). Local agrarian pursuits are thus embedded within this political ecology.

\section{Agricultural geography}

The earliest reputation Kadavu acquired was for its agriculture. American explorer Charles Wilkes (1845: 289) stated 'the people of Kantavu are industrious, and the chief said they had abundance of provisions'. Lord George Campbell marvelled at the irrigated taro patches and also noted 'cultivated yam grounds of considerable size' (Campbell 1881: 155). Over a century ago, Australian geographer J. P. Thomson (1889: 650) wrote: 'The Kadavuans are thorough practical agriculturalists, and their importance as food producers is fully recognised ... [they] are expert irrigationists, and its value in enriching and improving land has long been known to them'. He then described in some detail the irrigated taro terraces developed along streams, many of which survived the turn of the nineteenth century, for Ross (1909: 74) noted that 'here and there the slopes were terraced with taro beds, which were irrigated by channels leading to them from some permanent water supply'. Deane (1921: 210) later reported that 'the Kadavuans ... raise yams, taro, kawai [yam], kumala [sweet potato], and kaile [yam] in abundance': all root crops which, along with the arboreal starches breadfruit and plantain bananas, represent Fijian kakana dina (true food) (Turner 1984; Pollock 1986). This traditional emphasis has continued to the present day. Cook (1975: 17) listed Kadavu's 'main garden crops in their order of importance: taro, manioc, yams, sweet potato, breadfruit, cabbage, eggplant, pumpkin, bele [spinach: Hibiscus manihot], tomatoes, onion (varasa), and pineapple'. Although the recently introduced manioc, or cassava, has largely displaced other tubers, the five most important crops on the island remain the kakana dina, with taro the most important. While this may derive in some measure from Kadavu's peripheral position relative to markets in Suva and beyond, it also emphasizes the strength of traditional Fijian culture.

Kadavu has witnessed numerous attempts at commercializing agrarian production, beyond the colonial government mandate on tax gardens. Cotton, copra, bananas, cocoa, vanilla and pineapples have all been tried, with varying degrees of success. Cotton, as elsewhere in Fiji, did not last long. While coconuts are still in limited production, commercial bananas have disappeared due to disease. Coconut plantations were once more active, especially along the eastern coastal plains, but the vicissitudes of the copra market have taken their toll. Coconuts were never 
a major component of agrosystems in western Kadavu, although several villages continue to process oil on a very small scale. At Napoidi estate, the Babitu family has all but given up on coconuts, and it now looks to ecotourism as a way to make ends meet.

Currently, some taro is shipped to the Suva market, and there have been government-sponsored experiments with vanilla. But yaqona (kava), a member of the pepper family that figures prominently in Fijian custom and ritual, has been the notable success story. A mildly soporific beverage is extracted by mixing its carefully dried and pounded roots with water, and the formal presentation of bundles of dried roots is an important and frequent ceremonial ritual (sevusevu). Kava's value as an export commodity was stimulated by supposed health benefits and pharmaceutical potential. On Kadavu, yaqona eclipsed copra as the leading cash crop during the 1980s 'as a direct response to the fluctuations in price level of both commodities' (Sofer 1985b: 422), and then experienced an export boom during the late 1990s, when prices tripled and yaqona production throughout Fiji dramatically increased (Murray 2000). Subsequently, the overseas market collapsed following international reports of kava's potential for causing health problems; the future of yaqona production for export is not promising, though a government plan has proposed dramatic increases in kava cultivation on the island (Dinavuso 2002). Across Kadavu, other efforts are still being made to earn money from the soil; in October 2002, Daku villagers were tending to a newly established pineapple plantation, and had plans for introducing large-scale ginger production as the quest for a successful niche continued.

A more quantitative sense of contemporary crop production is provided by the National Agricultural Census (NAG) of 1991. Kadavu province (34,291 hectares) had 6,125 hectares under farms, or 18 per cent of the total land area. There were 2,440 farms, with an average farm size of 2.5 hectare, a farm being defined as:

an economic unit of agricultural production under single management ... exercised by an individual or household, jointly by two or more individuals or households, by a clan, village, or by a juridical person such as a corporation, cooperative or government agency.

(NAC 1992: 19)

Communally owned mataqali (extended kin group) lands are included in this tally, and constitute 3,451 hectares (56 per cent of the total), with the remainder mainly being counted as 1,695 hectares of freehold. Unlike the sugar producing areas of Fiji, there are no Indo-Fijian smallholders on Kadavu, and cultivating land as a galala (a Fijian farmer operating independently of the village) is rare (Brookfield 1988). Regarding root crops planted in 'pure stand', there were 760 hectares in cassava, 91 hectares of kumala (sweet potato), 78 hectares of dalo (taro) and 32 hectares of yams (both uvi and kawai combined), however the census excluded common 'root crop/vegetable' mixes, indicating the cash cropping bias of the data collection. Bananas were no longer in commercial production, a situation that reflected their demise throughout Fiji around 1970 (Brookfield 1987). Only by 
reading between the lines can the remarkable agrodiversity evident in the gardening strategies on Kadavu be appreciated.

Kava, the most valuable crop, was planted on 143 hectares as a 'pure stand', with an additional 145 hectares as cassava/taro/kava 'mixed and interplanted stand', and 538 hectares as taro/kava mix. This dryland taro and kava intercropping is the most common system in use in the district of Nabukelevu, in western Kadavu (see the following section). Besides kava, coconuts are the other main cash crop in terms of land area, with 421 hectares in pure stands, and an additional 289 hectares of mixed coconut/pasture. This total area of 710 hectares is planted to 25,304 trees, of which 17,395 were bearing nuts. Finally, a review of livestock numbers revealed some 610 cattle, but 1,659 goats and 7,441 pigs; the latter figure represents nearly one pig for every person residing on the island - but ironically pig damage is an ongoing concern in many villages. The remainder of this chapter examines land use transformations in the western portion of Kadavu, with particular reference to irrigated terracing as a vestige of former intensification.

\section{Western Kadavu}

To understand agrosystem alterations on Kadavu it is useful to examine conditions and crops on the western part of the island, which remains every bit as diverse as when Seeman (1862: 212) visited the village of Talaulia and witnessed 'cultivated grounds where the people were busy with their crops of sugar canes, yams, taros, and plantains'. But there has been both stability and change. Contemporary 'Kadavu agriculture is typically a semi-subsistence form of production characterized by shifting cultivation patterns' (Sofer 1985b: 420). Many garden areas are planted with various crops that are part of the traditional subsistence system but from which villagers may also derive some cash income. A few exceptions represent predominantly commercial production at a local scale, and it is valuable to examine these typical examples of cash cropping on Kadavu.

Behind the village of Dagai on the north coast is a low, wet area in the forest, close to where a stream enters the sea. This area was formerly used for the cultivation of via kana (Cyrtosperma chamissonis: giant swamp taro). Claiming incessant pig damage to the taro, villagers have now planted this area to voivoi, the smaller domesticated variety of pandanus used for weaving. Small plots are planted wherever soil conditions warrant. Pandanus has long been used for making fans, baskets and fine mats. Degener (1949: 128) noted that voivoi was cultivated in plantations, and concluded that the plant was indeed a cultigen, for it 'never flowers like the common wild pandanus'. Dagai villagers harvest the raw material from their voivoi groves and process it into a marketable commodity. They cut and gather the green leaves, carry them in large bundles back to the village, strip off the sharp points from the leaf edges with a shell tool or knife and remove the central spine, in preparation for sun drying the leaves. After drying, the leaves are rolled into bundles ready for transporting to Suva, to be sold for mat weaving. As a nonperishable and relatively lightweight product, voivoi is an almost perfect crop for the isolated agricultural economy of Kadavu, while it also perpetuates the traditional 
craft of weaving and encourages the manufacture of customary mats (na ibe) elsewhere in Fiji.

Much the most important cash crop grown on Kadavu is kava, and traditional Fijian cultural practices have created a favourable environment for commercial production. Like voivoi, kava is dried before transport, and hence also becomes a relatively lightweight and valuable agricultural export. 'Kava is an extremely viable cash crop among small-scale farmers' and is 'also highly environmentally sustainable because of its relatively low demands on soil ecosystems and the great possibilities for rotational production' (Murray 2000: 361). Nearly every village on Kadavu has grown and marketed kava as a cash crop, and commercial marketing began there during the 1930s (Brookfield 1985: 190). Other Fijians often prefer Kadavu kava, and roots (waka) originating from the island usually fetch higher prices at the Suva market. Kadavu thus became by far the leading supplier to Suva, representing 'more than forty percent of the total' stock in the market (Sofer 1985b: 428). The western Kadavu district of Nabukelevu is particularly active in the Suva market, and it has a long tradition of production; indeed, in September 1860 Seeman (1862: 212) visited the village of Lomati and 'saw some fine plants of the different kinds of kava, for which Kadavu is renowned'.

Kava is still grown extensively at Lomati, where garden lands are situated on the northern and eastern flanks of the volcano (Figure 4.2), and is typically intercropped with dryland taro. In this way, the large taro leaves provide shade for young kava plants. Dalo (taro) and yaqona (kava) are planted as complementary sets

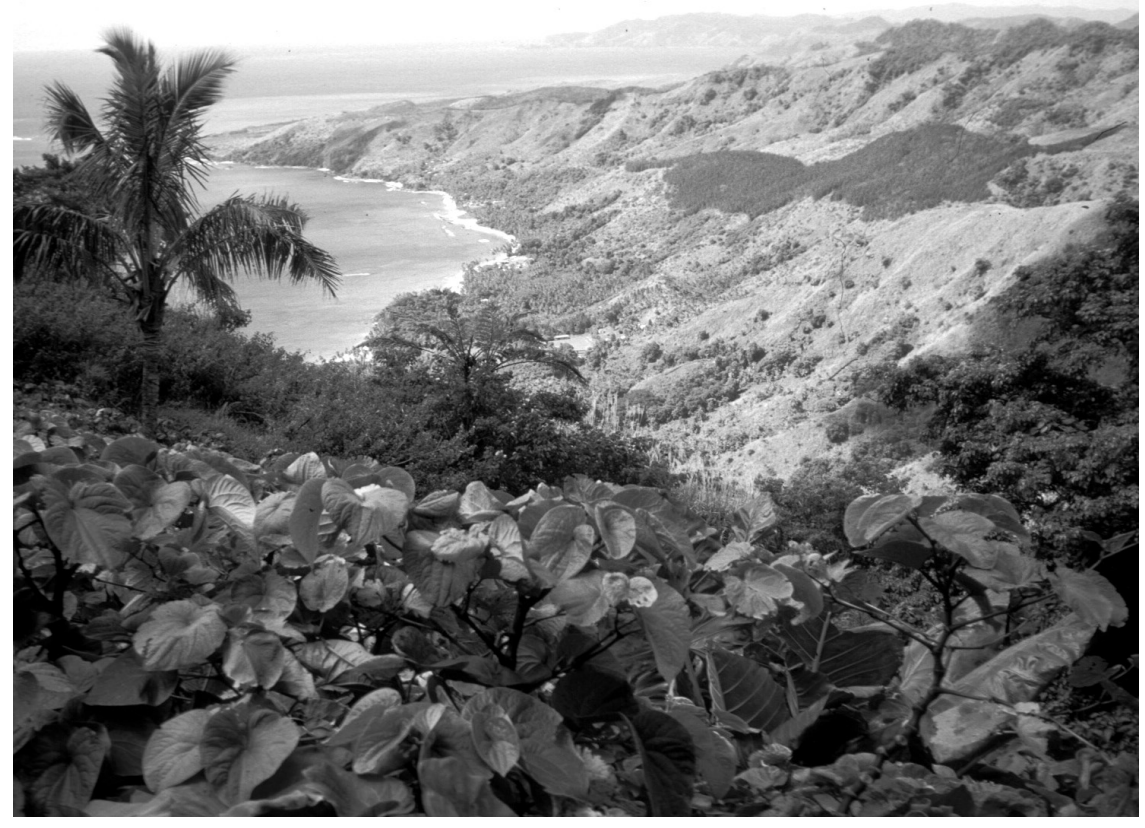

Figure 4.2 Yaqona garden on the slopes of Nabukelevu volcano, Kadavu. 
spaced a metre apart in small hillocks, which keep the soil loose and friable for optimum root development, with yaqona in the middle and dalo to each side. Gardens are established on steep terrain with slopes of up to 40 degrees. Logs may be placed across the gradient to reduce erosion. After at least ten months and within two years of its planting, the dalo will be harvested, and gardens will often then be double-cropped. Upon harvesting, the mound is again planted with dalo cuttings (suli). Following a second harvest of dalo, no further planting is done, and it takes at least two years before the yaqona is mature. Harvested yaqona roots are brought back to the village for drying on old mats or corrugated metal roofs. Besides its association with dryland taro, the agrodiversity of yaqona production is evident from additional intercropping with other food plants, such as bananas and plantains (Musa spp.), dalo ni tana (Xanthosoma sagittifolium) and via or giant taro (Alocasia spp.). A further advantage of this system is that the same piece of land remains in both the subsistence and cash systems, indicating the blurring of this division. Yaqona grown at Lomati is consumed in the village, but it is also taken to urban markets. On Kadavu, as elsewhere in Fiji, there is no sharp divide between subsistence and cash cropping.

Agrodiversity is also apparent in the wide range of cultivars for each of the main crops being grown at Lomati, including six cultivars of kava, fourteen types of taro, ten varieties of breadfruit, five kinds of plantains, five types of coconut, four varieties of sweet potato, three kinds of giant taro, three varieties of cassava and no less than nineteen cultivars of yam (Table 4.1). The last two Colocasia taros (vavai laua and vujikoto karakarawa) are particularly well suited to wetland production, although irrigation systems in this area have been abandoned for some time. Not surprisingly, traditional food crops such as taro, yams and breadfruit comprise many more cultivars than does the more recently introduced cassava. Several crop varieties have the names of other Fijian islands (and also Samoa and Tonga), indicating various forms of local and regional diffusion.

In the stream valley behind the neighbouring village of Talaulia, a wide assortment of food crops grow on abandoned terracing once used exclusively for irrigated taro. Although no longer functioning, the system's architecture is still discernible. A substantial spring flows into a large reservoir (vaso) formed by a rock and earth dam some 33 metres in length, from which water was once transported 200 metres across a ravine through bamboo piping, then around the side of a hill to feed a flight of terraces. The rich silt in the basin of the former reservoir affords an excellent and fertile site for mixed planting of yaqona, dalo, via and dalo ni tana. The stair-step plots, constructed exclusively for pondfield taro and last irrigated around 1970, have now been dryland planted to a considerable mixture of tree crops and both perennial and annual food plants. Various cultigens were growing together: coconut, breadfruit, taro, papaya, chilies, tomatoes, dalo ni tana, sweet potato, eggplant, bele and kava - intercropping taken to its extremes. Other crops in various combinations include cassava, yams and bananas. The most common mix is dalo/ yaqona, although uvi/sila (yams/maize) occupy some of the abandoned terraces. Terrace walls, formed of mud and earth, have eroded and slumped and now offer additional planting surfaces for pineapple, bele and kokoto, the leaves from which 
Table 4.1 Cultivars of main food crops grown in Nabukulevu District, western Kadavu

\begin{tabular}{|c|c|c|c|}
\hline Crop & Cultivars & & \\
\hline $\begin{array}{l}\text { Dalo (Colocasia esculenta): } \\
\text { taro }(14)\end{array}$ & $\begin{array}{l}\text { korokece } \\
\text { manua } \\
\text { tailevu } \\
\text { mataiwalu } \\
\text { vavai laua }\end{array}$ & $\begin{array}{l}\text { ilo ilo } \\
\text { nereo } \\
\text { sadri } \\
\text { qere } \\
\text { vujikoto karakarawa }\end{array}$ & $\begin{array}{l}\text { samoa } \\
\text { tausala samoa } \\
\text { sekaseka } \\
\text { vavai ni samoa }\end{array}$ \\
\hline $\begin{array}{l}\text { Via (Alocasia macrorrhiza): } \\
\text { giant taro }(3)\end{array}$ & via ni tonga & viakau & viadina \\
\hline $\begin{array}{l}\boldsymbol{U} \boldsymbol{v} \boldsymbol{i} \text { (Dioscorea } \text { spp.): } \\
\text { yam (19) }\end{array}$ & $\begin{array}{l}\text { togovuso } \\
\text { kasokaso } \\
\text { mataqiliqili } \\
\text { kaunisela } \\
\text { uvikuro } \\
\text { saukaladuci } \\
\text { sebu }\end{array}$ & $\begin{array}{l}\text { veuwa } \\
\text { iota } \\
\text { rotuma } \\
\text { zwalesi } \\
\text { damuni } \\
\text { moala }\end{array}$ & $\begin{array}{l}\text { kaumaile } \\
\text { kaumani } \\
\text { uvinioutuna } \\
\text { daniela vulavula } \\
\text { daniela dradra } \\
\text { uviniugini }\end{array}$ \\
\hline $\begin{array}{l}\text { Kumala (Ipomoea batatas): } \\
\text { sweet potato }(4)\end{array}$ & $\begin{array}{l}\text { apakuki } \\
\text { belesilika }\end{array}$ & $\begin{array}{l}\text { kumala vulavula } \\
\text { kumala dromodromo }\end{array}$ & \\
\hline $\begin{array}{l}\text { Cassava (Manihot esculenta): } \\
\text { manioc }(3)\end{array}$ & vulatolu & sokobale & tavioka dromodromo \\
\hline $\begin{array}{l}\text { Uto (Artocarpus altilis): } \\
\text { breadfruit }(10)\end{array}$ & $\begin{array}{l}\text { uto levulevu } \\
\text { balekana } \\
\text { uto ni samoa } \\
\text { maliva }\end{array}$ & $\begin{array}{l}\text { uto dina } \\
\text { uto saca } \\
\text { uto bovua }\end{array}$ & $\begin{array}{l}\text { uto kogo } \\
\text { uto vatu } \\
\text { uto cokocoko }\end{array}$ \\
\hline Vudi (Musa spp.): plantain (5) & $\begin{array}{l}\text { luveniika } \\
\text { mami }\end{array}$ & $\begin{array}{l}\text { waiwaileka } \\
\text { leqanakurokava }\end{array}$ & makogai \\
\hline $\begin{array}{l}\text { Niu (Cocos nucifera): } \\
\text { coconut }(5)\end{array}$ & $\begin{array}{l}\text { niu ni tonga } \\
\text { niurea }\end{array}$ & $\begin{array}{l}\text { niudrau } \\
\text { niu ni rotuma }\end{array}$ & niuleka \\
\hline $\begin{array}{l}\text { Yaqona (Piper methysticum): } \\
\text { kava }(6)\end{array}$ & $\begin{array}{l}\text { yaqona loa } \\
\text { yaqona karawa } \\
\text { yaqona nigau }\end{array}$ & $\begin{array}{l}\text { yalu } \\
\text { beranavakacoko } \\
\text { kubukubuleka }\end{array}$ & \\
\hline
\end{tabular}

Source: 1992 fieldwork.

make traditional skirts. Diversity is a distinguishing characteristic in Kadavu agricultural landscapes.

Many aspects of traditional Fijian subsistence strategies may best be portrayed as agroforestry (Thaman 1994). As Brookfield (2001b: 55) points out: 'Whether or not agroforests are part of the system, the farm does not end where the field meets the wood'. In addition to the cultivated tree crops such as coconut and breadfruit, islanders utilize a wide variety of wild fruit and nut trees. These include $i v i$, the socalled Tahitian chestnut (Inocarpus edulis), dawa (Pometia pinnata), vutukana (Barringtonia edulis) and kavika (Eugenia malaccensis). Other trees are set aside for craft purposes, such as the vesi (Intsia bijuga), which is widely used for carving tanoa (traditional wooden bowls for mixing and serving kava). In Nabukelevu, groves of trees are still tended for fuelwood supplies, while others represent haunts of old deities, from 
where wood cannot be taken (Kuhlken 1997). One such sacred grove is situated between the villages of Talaulia and Dagai, adjacent to the voivoi plantation.

Nasegai village, at the head of a bayment (Figure 4.1), was the subject of a recent case study by Ratuvakacereivalu, who noted that:

semi-subsistence producers in Nasegai typically operate two or three gardens: the main garden (accruing the greater proportion of the owner's labour inputs) being associated with the major traditional cash crop (yaqona), with secondary gardens being directed towards crops for household consumption (cassava).

(1992: 93)

In both Dagai and Nasegai, farms must now be located away from the village to avoid pig damage:

pockets of arable land close to the village are susceptible to domestic pig damage since poorly maintained pigsties, coupled with the apparent custom of households releasing their pigs for unsupervised 'daily exercise' (most commonly until the pigs voluntarily return to their sties or the owner re-pens them), effectively make farming close to the village synonymous with providing a 'charitable soup-kitchen' for village pigs.

(1992: 92)

In this situation, the apparent stagnation in agricultural development was attributed to 'the easy attainment of subsistence affluence in Nasegai, coupled with a significant increase in the price of yaqona after the 1987 coup' (Ratuvakacereivalu 1992: 93). In this relatively unusual context, cash crop incomes have discouraged the maintenance of the traditional agricultural system.

\section{Intensive agricultural landscapes}

Agrodiversity is readily apparent in the variety of soil and water management methods in use on Kadavu, especially the creation of specialized agricultural landscapes and landforms. Raised fields (vиелue) are common on a small scale along coastal plains on the outskirts of many villages. Numerous advantages prompt their construction and maintenance, including the ability to cultivate naturally swampy sites and the higher crop yields obtained from the combined fertilizing and mulching derived from scooping out the ditches and piling the muck on the beds around the plant stalks. Raised fields on Kadavu are utilized primarily for dalo (Colocasia) production, rather than via kana (Cyrtosperma), but they have also been used to boost the harvest of introduced cultigens such as cassava. Fields are planted in different combinations and patterns, resulting in varied aesthetics. Near Tabuya on the south coast, a wheel pattern was created, with cassava planted as the large hub and dalo beds emanating as wide spokes. At Ravitaki, elaborate raised fields were constructed among the boulders of a stream floodplain, where an array of crops were interplanted, including bananas, coconut, yams, sweet potatoes, maize, sugar 
cane and several varieties of taro (Figure 4.3). By contrast, yam mounds, once a ubiquitous feature of agricultural landscapes on many Fijian islands, have virtually disappeared from Kadavu. Replacement of yams by other, more easily cultivated tubers, such as cassava, has also brought about the demise of mounding and trellising as agronomic techniques. Intensive agricultural techniques have become more selective.

Irrigated terracing for taro production was likewise more widespread on Kadavu in the past. Aerial photographs show evidence of former terracing in stream valleys and hillsides throughout the island (Kuhlken 1994), but irrigated terrace systems (laua) are now active in just five locations. While they have been abandoned or transformed elsewhere on Kadavu, terraces are still a major feature of the agricultural landscape in Ravitaki (Figure 4.4), where they are differentiated according to land tenure and complexity of the systems (Kuhlken 1993, 2002). Terraces are a communal agricultural resource, managed on a four-year cycle of wet and dry cultivation, with alternate fallow periods. As elsewhere in Fiji, pre-colonial settlement was concentrated in fortified hilltop locations, and food gardens were located close to these defensible habitation areas (Kuhlken 1999). The village terrace system at Ravitaki probably dates to this period, and informants believe these irrigated fields are at least a hundred years old. Villagers plant taro in February, so that it will mature and be ready to eat in December. Many kai Ravitaki who live elsewhere return to the village to be with their relations at Christmas, and look

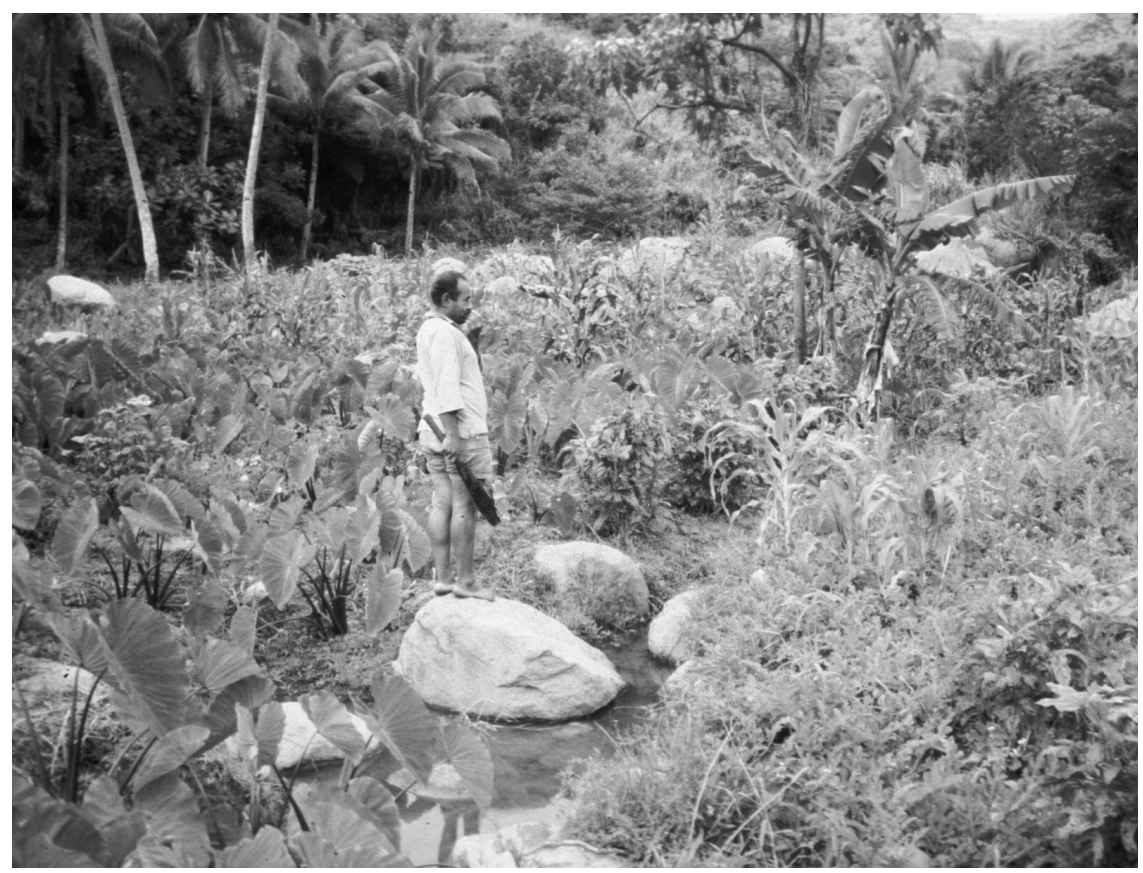

Figure 4.3 Raised fields (vuevue) with interplanting at Ravitaki, Kadavu. 


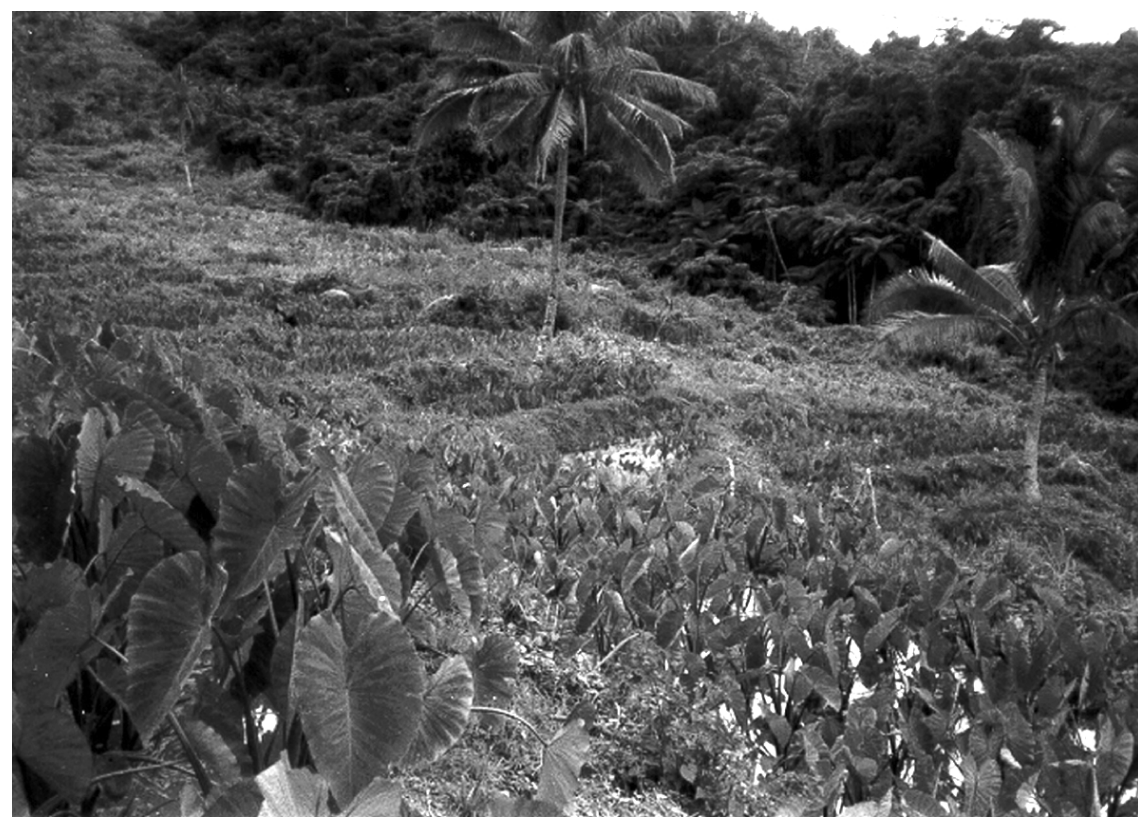

Figure 4.4 Village-owned taro terraces at Ravitaki: some of the last irrigated terrace systems in Fiji.

forward to the big holiday feast. Besides social ecology, additional motives for maintaining the terraces relate to drought and cyclone hazards: taro may be left in a pondfield (or 'brookfield') for many months and still retain its flavour and vitality. Thus, the laua act as a form of storage for an otherwise perishable food item, another advantage over dryland taro cultivation.

Other agrosystems in use at Ravitaki complement the large village laua and are essential components of the agrarian landscape there. The arable land base extends inland for some 3 kilometres to the crest of the island's central spine, and is under the 'ownership' or use-control of the various village mataqalis. Garden lands in various stages of the swidden cycle are evident on slopes nearly to the top of the ridgeline. Dryland cultivation is conducted for an assortment of crops, including yams, sweet potatoes, taro, cassava and yaqona. In addition to the large communally operated system, smaller sets of irrigated taro terraces are found in several locations. These gardens belong to individual mataqalis and are utilized by members of whichever mataqali maintains traditional claims to the land. Mataqali members establish rights to use these irrigated areas in the same way that a household (itokatoka) comes each year to garden the same area of dry ground. As long as the family continues to benefit from the land, nobody else will ask to garden there. If a household in the same mataqali notices that a piece of agricultural land is not being utilized, they may petition the head of the mataqali for the right to use it. Sometimes a household may ask to cultivate land that belongs to a different mataqali. Irrigated 
gardens are highly coveted, and once a family has established the right to use these laua they will not lightly abandon them. Consequently, many locations have been productively used for several generations, and individual sets of pondfields, identified by name, are constructed wherever an appropriate water source can be coaxed into providing a steady reliable flow.

At Solodamu, a perennially cultivated set of irrigated terraces is situated along Savulutu Creek, about a kilometre upstream from Tavuki Bay. When compared with the village system operating at Ravitaki, the area of these pondfields is not large, either collectively or individually, but the Solodamu gardens display interesting and distinctive features. As a way to avoid lengthy fallowing or cyclical rotations, some of the plots are planted in a half-pondfield, half-raised field fashion (Figure 4.5). Rather than using the customary hollowed out tree trunk or bamboo as an aqueduct, water is conveyed to the plots via plastic pipe. Where a stone would traditionally break the force of the water falling into the pondfield, a sheet of corrugated sheet metal here serves the same purpose. Such small details may seem trivial or insignificant, but the innovative adoption of these modern materials into terrace infrastructural design bodes well for the continued utilization and upkeep of the system: even the most 'traditional' agricultural system thus continues to evolve.

\section{Conclusion}

Kadavu people continue to exhibit the attention to agrarian pursuits that historically earned the island its deserved reputation as a lush and productive garden.

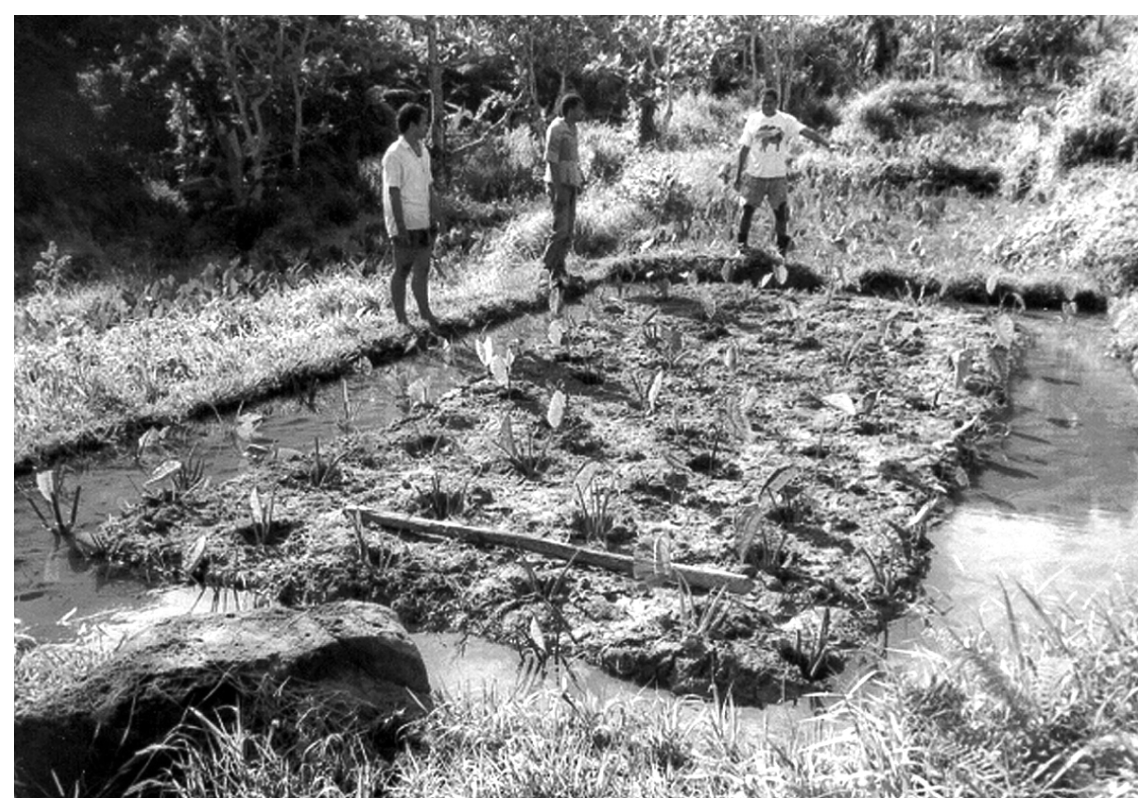

Figure 4.5 Terraced taro garden at Solodamu, Kadavu. 
Agrodiversity is evident across many scales and levels of complexity, and encompasses interplanting, multicropping, swidden-fallow, land rotation, irrigation and water management, maintaining a variety of cultivars and adopting new cultigens. This runs counter to the situation elsewhere in Fiji, where monocultural cash cropping or reliance on just a few food plants has severely diminished agrodiversity (Ward 1987). Kadavu villagers have sought to achieve a measure of productive selfsufficiency by spreading agrosystem risk across multiple environmental niches and by using a variety of techniques. In most villages, such diversity remains evident.

Intensive taro production was one component of a diversified agricultural base that featured the well-documented bimodal pattern of 'the wet and the dry' (Kirch 1994). While dryland methods are more prevalent, Kadavuans continue to invest time and labour in irrigated terrace construction and maintenance, seeking to overcome agronomic constraints and natural hazards and increase productivity. Villagers at Ravitaki cite the ability to forestall potential drought and cyclone damage, as taro yields are higher and storage capacity is enhanced. But other factors, including cultural traditions, communal labour organization, preferred taste and the social and ceremonial role of wet taro, are equally significant incentives (Kuhlken 2002).

Moreover, sustainability is not some lofty ideal, but is achieved in practice, as the Ravitaki laua have been utilized continuously for nearly a century. A comparable situation exists on Matuku, the next island to the east, where 'villagers claimed they had grown dalo in the same swampland over many generations without adding fertilizers and without affecting the yield' (Siwatibau 1984: 365). Irrigated terraces also remain on nearby Gau, another relatively remote and isolated island only marginally involved in the modern capitalist geography of Fiji (Watling 1984). Ravitaki villagers stressed that custom guided both the design and operation of the irrigated terraces there. Though exemplification of traditional cultural ecologies on Pacific islands may be naïve and nostalgic, and simply the latest iteration of Western capitalism's yearning for a simple agrarian life amongst noble savages (Connell 2003: 571), on Kadavu at least these artistically created earthworks are tangible and visually potent symbols of harmonious relations with the land. Continued operation of these gardens is a notable display of resilience on an island that lacks direct economic ties with the rest of Fiji, let alone the 'world system'. The agronomic knowledge thus preserved in such peripheral locations may prove immensely useful to a small island nation struggling to achieve greater selfsufficiency and sustainability. Isolation enables Kadavu farmers to weather the storms of economic uncertainty by remaining cognizant of the value of diversity in semi-subsistence agricultural production.

Irrigated terracing, a key component of agrodiversity, has persisted on Kadavu because of the island's adherence to traditional Fijian culture and because of its entrenched position on the periphery of the modern Fijian space-economy (Britton 1980; Sofer 1988). This has inverted the probable situation prior to European contact and the imposition of capitalist structures. Previously, across Fiji intensive agricultural systems either reflected cohesive social organization and control within core areas of the major chiefdoms or else represented more locally specific 
expressions of social and political ecology, as manifested by the massive terrace systems and the pre-contact cultivated landscapes of the Nakauvadra Range or the upper Sigatoka River (Kuhlken 1999; Field 2002). These days, for most locations across Fiji, labour inputs to subsistence agriculture have been curtailed, and traditional intensive landscapes of production only occur where there are few opportunities to participate in the larger economy.

Even during pre-contact times, Kadavu's relative isolation acted to limit opportunities for exchange of food items with other areas and hence inhibited crop specialization. Unlike other Fijians, who were more closely connected and politically integrated, Kadavuans found it necessary to fully exploit every gardening strategy available to them. Kadavu specialized in building wooden canoes and woven sails in an attempt to overcome its peripheral position, probably amplified by a long period of interaction with Tonga. The present concentration of voivoi gardens on Kadavu can partly be seen as a vestige of past production, when sails were woven from pandanus. Kadavu never participated in the power struggles and political intrigues of the larger Fijian chiefdoms, and expressed independence both in external relations and internal development. European exploitation of Kadavu's resources never took place. There were no commercial stands of sandalwood to cut, and whalers were but ephemeral visitors. During the 1860 s, with the onset of plantation agrosystems in Fiji, Kadavu was initially targeted for its agricultural reputation. Early settlers tried cotton, but attempts at establishing an export economy failed; chiefs on Kadavu did not want settlers there, local people refused to work for them and the volatile and evanescent global marketplace largely negated that option (Young 1984: 142-46). When Suva became Fiji's primate city, Kadavu was left to fend for itself, without the advantages of chiefly connections or missionary influence. That traditional subsistence agrosystems have endured, given these historical conditions, is no surprise.

Part of the dynamism evident in the island's agrarian landscapes is the disappearance of many of the more intensive forms of crop production. Irrigated terracing is a manifestation of traditional Fijian culture that has diminished along with such things as pottery production, canoe building, sail making and thatchedroof dwellings. Diet and food preferences likewise have undergone transformation, contributing to agricultural disintensification, since the customary root crops (yams and taro) traditionally received the most lavish attention. Brookfield and Hart (1971: 121) found there was generally a 'replacement of yams by manioc in Fiji', and for taro they decided that 'reduction in irrigation of Colocasia is partly due to introduction of Xanthosoma, but more to a spread of the food base, so that lower yields of Colocasia can readily be tolerated'. Thaman and Thomas (1980: 3) concluded that 'ease of cultivation, environmental tolerance and productivity make cassava synonymous with change in much of the tropical world'. The 1991 Census of Agriculture indicated certain broad trends, when compared with 1953 crop data (Ward 1965: 204), with dramatic increases in cassava, from 20 per cent of the crop area in 1953 to 47 per cent in 1991, and only slight increases for yaqona, which ranged between 10 and 25 per cent across the island, depending on district, in 1953 to 27 per cent overall in 1991. Regarding the two most traditional root crops, the 


\section{Robert Kuhlken}

area planted to taro decreased from between 30 and 35 per cent to 23 per cent, while yams declined from a range of 10-25 per cent of garden area in 1953 to a mere 2 per cent in 1991. Even in isolation, change has been as apparent as continuity.

Despite the shift in crop mixes, Kadavu still evinces a commitment to subsistence agriculture as a priority, although this runs counter to the prevailing wisdom of economic development strategies. A recent report by a government agricultural officer even went so far as to claim that Kadavu villagers 'have shown little interest to become commercial farmers since they are so used to subsistence farming' (Dinavuso 2002: 173). Yet this resonates like an echo of Governor Gordon's nineteenth century 'tax garden' scheme, and it ignores repeated attempts at seeking export opportunities by experimenting with various cash crops, albeit with limited success. Bananas once flourished here, copra amounted to little, and while pineapples and ginger are now being tried, the products from Kadavu that have succeeded essentially support and perpetuate customary lifeways. The two most important exports are voivoi and yaqona, both emblematic of traditional Fijian culture.

Villagers on Kadavu have shrewdly sought to fill specialized demand niches by seeking to include limited cash-cropping activity within the overarching context of semi-subsistence agrosystems. No longer able to operate strictly as a barter economy, cash is sometimes obligatory, even for this isolated population. The most common necessities requiring purchase are batteries for radios and electric torches, kerosene for lamps and children's school uniforms. There is also the expectation of monetary contributions to the Church. The one export of any real use to the modern capitalist economy has ironically been labour, yet labour migration and circular mobility tend to reinforce the spatial structure of uneven development, ensuring Kadavu remains an economic backwater. Here as elsewhere, 'survival of a "Fijian way of life" in the outer islands is something of a faute de mieux, the product of an externally imposed political economy more than of conscious resistance' (Bayliss-Smith et al. 1988: 8).

By choice and by default, a rich tradition of agrodiversity persists in adversity on Kadavu because of geographic isolation and a scarcity of profitable export commodities. Having had little to offer the first wave of world system imposition in the nineteenth century, Kadavu continues to evade the supposed benefits of 'neoliberal globalization' (Murray 2001). By maintaining a strong foundation of subsistence diversity, Kadavu villagers are able to provide the flexibility necessary for experimentation with limited cash-cropping opportunities. This allows traditional agricultural systems to persist even while accommodating and incorporating innovation. As Brookfield (2001a: 189) has noted: 'In a constantly changing, never stable world, adaptation, innovation and the seizing of opportunity have been, and until now remain, the keys to survival and successful change'. Finding opportunities in remote islands remains difficult, yet ecotourism has become a lucrative new trend, and peripheral locations such as Kadavu have one advantage over other places in Fiji, which are already developed for an older, more standardized visitor experience. Perhaps a form of 'agrotourism' might be initiated on Kadavu, where 
visitors could experience the many different crops and the variety of production techniques, in a context where they would be sitting on woven mats and drinking bowls of kava. Such endeavours might strengthen Fijian cultural traditions, ensuring the continuation of subsistence land use patterns and preventing commercial monocropping from degrading land and life. As elsewhere in Fiji, 'land that could otherwise be used for cash crops is preserved for traditional agriculture that has cultural significance' and communally managed land reveals 'lower levels of ecological degradation' (Powell 1998: 92). The Kadavu model of maintaining traditional agrodiversity for village subsistence requirements while experimenting with marketable products from the soil offers future resilience; out of adversity it illustrates successful and dynamic adaptation to change for this island on the outer edge.

\section{References}

Bayliss-Smith, T, Bedford, R, Brookfield, H and Latham, M (1988) Islands, Islanders and the World: The Colonial and Post-colonial Experience of Eastern Fiji, Cambridge: Cambridge University Press.

Blaikie, P and Brookfield, H (1987) Land Degradation and Society, London: Methuen.

Britton, S (1980) The Evaluation of a Colonial Space-economy: The Case of Fiji, Fournal of Historical Geography, 6, 251-74.

Brookfield, H (1972) Intensification and Disintensification in Pacific Agriculture: A Theoretical Approach, Pacific Viewpoint, 13, 30-48.

- (1977) Population, Resources and Development in the Eastern Islands of Fiji, Population and Environment Project in the Eastern Islands of Fiji, Report No. 1, New York: United Nations MAB/UNESCO/UNFPA.

- (1984) Intensification Revisited, Pacific Viewpoint, 25, 15-44.

(1985) An Historical and Prospective Analysis of the Coconut Economy and the

Coconut Districts of Fiji, in H Brookfield et al. (eds), Land, Cane and Coconuts: Papers on the

Rural Economy of Fiji, Canberra: Research School of Pacific Studies, Australian National University, pp. 111-247.

- (1987) Export or Perish: Commercial agriculture in Fiji, in M Taylor (ed.), Fiji: Future Imperfect?, Sydney: Allen and Unwin, pp. 46-57.

_ (1988) Fijian Farmers Each on His Own Land: The Triumph of Experience Over Hope, Fournal of Pacific History, 23, 15-35.

(2001a) Intensification and Alternative Approaches to Agricultural Change, Asia Pacific Viewpoint, 42, 181-92.

-(2001b) Exploring Agrodiversity, New York: Columbia University Press.

— and Hart, D (1971) Melanesia: A Geographical Interpretation of an Island World, London:

Methuen.

Burns, A (1963) Fiji, London: Her Majesty's Stationery Office.

Campbell, G (1881) Log Letters From the Challenger, London: Macmillan.

Connell, J (2003) 'Island Dreaming: The Contemplation of Polynesian Paradise', Fournal of Historical Geography, 29, 554-81.

Connell, J and Lea, J (2002) Urbanisation in the Island Pacific: Towards Sustainable Development, London: Routledge.

Cook, B (1975) Na kai Kadavu: A study of Bilingualism, Acculturation, and Kinship in the Fiji Islands, unpublished $\mathrm{PhD}$ thesis, Stanford University. 


\section{Robert Kuhlken}

Deane, W (1921) Fïian Society, London: Macmillan.

Degener, O (1949) Naturalist's South Pacific Expedition: Fiji, Honolulu, HI: Paradise of the Pacific Ltd.

Dinavuso, M (2002) Fiji: Constraints to Agricultural, Fishery and Forestry Production in Kadavu, Integrated Community Development Papers, Tokyo: Asian Productivity Organization, pp. 173-83.

Field, J (2002) GIS-based Analyses of Agricultural Production and Habitation in the Sigatoka Valley, Fiji, in T Ladefoged and M Garves (eds), Pacific Landscapes: Archaeological Approaches, Los Osos, CA: Easter Island Foundation, pp. 97-124.

Hocart, A (1929) Lau Islands, Fiji, Bishop Museum Bulletin No. 62, Honolulu, HI: Bishop Museum.

Kirch, P (1994) The Wet and the Dry: Irrigation and Agricultural Intensification in Polynesia, Chicago, IL: University of Chicago Press.

Kuhlken, R (1993) Agricultural terracing in the Pacific Islands, Insula, 2(1), 56-60.

_ (1994) Agricultural Terracing in the Fiji Islands, unpublished $\mathrm{PhD}$ thesis, Louisiana State University.

(1997) Sacred Landscapes and Settlement Mythology of the Fiji Islands, The Pennsylvania Geographer, 35, 173-202.

- (1999) Warfare and Intensive Agriculture in Fiji, in C Gosden and J Hather (eds), The Prehistory of Food, London: Routledge, pp. 270-87.

- (2002) Intensive Agricultural Landscapes of Oceania, Fournal of Cultural Geography, 19, 161-95.

Levick, W and Bedford, R (1988) Fiji Labour Migration to New Zealand in the 1980s, New Zealand Geographer, 44, 14-21.

Moseley, H (1879) Notes by a Naturalist: An Account of Observations Made During the Voyage of H.M.S. Challenger (1944 reprint), London: T. Werner Laurie, Ltd.

Murray, W (2000) Neoliberal Globalisation, Exotic Agroexports, and Local Change in the Pacific Islands: A Study of the Fijian Kava Sector, Singapore Fournal of Tropical Geography, 21,355-73.

- (2001) The Second Wave of Globalisation and Agrarian Change in the Pacific Islands, Fournal of Rural Studies, 17, 135-48.

National Agricultural Census (NAC) (1992) National Agricultural Census of Fiji, Suva: Government Printer.

Nukubalavu Estates 2003. [www.fijilive.com/waisalima/beach2.html]. Accessed April, 2003.

Pollock, N (1986) Food Classification in Three Pacific Societies: Fiji, Hawaii, and Tahiti, Ethnology, 25, 107-17.

Powell, P (1998) Traditional Production, Communal Land Tenure, and Policies for Environmental Preservation in the South Pacific, Ecological Economics, 24, 89-101.

Ratuvakacereivalu, J (1992) The Fijian Dilemma: A Descriptive Analysis of Rural Development Policy in Fiji, unpublished MA thesis, University of Queensland.

Ross, G (1909) Fiji and the Western Pacific, Geelong: H. Thacker.

Seeman, B (1862) Viti: An Account of a Government Mission to the Vitian or Fijian Islands 1860-61, Folkestone: Dawsons of Pall Mall.

Siwatibau, S (1984) Traditional Environmental Practices in the South Pacific - A Case Study of Fiji, Ambio, 13, 365-68.

Sofer, M (1985a) The Dependency Paradigm Applied to the Fijian Periphery, Singapore Journal of Tropical Geography, 6, 127-38.

- (1985b) Yaqona and Peripheral Economy, Pacific Viewopoint, 26, 415-36. 
(1988) Core-periphery Structure in Fiji, Environment and Planning D: Society and Space, 6, $55-74$.

-(1992) Labour Circulation and the Village Economy in Fiji, Singapore Fournal of Tropical Geography, 13, 118-29.

Thaman, R (1993) Pacific Island biodiversity: A Basis for Ecological, Cultural, and Economic Survival', in E Waddell and P Nunn (eds), The Margin Fades: Geographical Itineraries in a World of Islands, Suva: University of the South Pacific, pp. 49-65.

-and Thomas, N (1980) The Cassava Invasion: The Cultural, Nutritional, and Ecological Impact of Cassava on Pacific Island Food Systems, Paper presented at the 2nd Papua New Guinea Food Crops Conference, Goroka.

Thomson, J (1889) The Island of Kadavu, Scottish Geographical Magazine, 5, 638-52.

Tippett, A (1968) Fijian Material Culture, Bishop Museum Bulletin No. 232, Honolulu, HI: Bishop Museum.

Turner, J (1984) 'True Food' and First Fruits: Rituals of Increase in Fiji, Ethnology, 23, $133-42$.

Ward, R (1961) Internal Migration in Fiji, Fournal of the Polynesian Society, 70, 257-71.

- (1964) Cash Cropping and the Fijian Village, Geographical fournal, 130, 484-506.

(1965) Land Use and Population in Fiji: A Geographical Study, London: Her Majesty's Stationery Office.

-(1987) 'Native Fijian villages: A questionable future?', in M Taylor (ed.), Fiji: Future Imperfect?, Sydney: Allen and Unwin, pp. 33-45.

Watling, D (1984) Irrigated Terrace Cultivation of Dalo at Nawaikama, Gau, Domodomo, 2, $121-35$.

Wilkes, C (1845) Narrative of the United States Exploring Expedition, volume 3, Philadelphia: Lea \& Blanchard, (1985 Reprint, Suva: Fiji Museum).

Woodrow, P (1980) Geology of Kadavu, Bulletin No. 7, Suva: Government of Fiji, Mineral Resources Department.

Young, J (1984)Adventurous Spirits: Australian Migrant Society in Pre-cession Fiji, Brisbane: University of Queensland Press. 


\title{
5 Tree crops and the cultivated landscapes of the southwest Pacific
}

\author{
Jean Kennedy and William Clarke
}

\begin{abstract}
The adaptability of farmers, using a diverse range of strategies, is a central issue. It is still greatly undervalued in a wide professional literature on agricultural development. Yet the circumstantial evidence of longer-term adaptability is overwhelming ... the farm does not end where the field meets the wood. We need to look at the continuum between the two and examine the manner in which the managed and unmanaged wild elements relate to the cultivated land and plants ... cultivated forests are created in some parts of the world. They range from forests in which only a few key species are actually planted, leaving everything else to natural process, to highly complex agroforests in which everything is created by the farmer. Often, it is not easy for an observer to know what is natural and what is planted, and errors are common.... Two common strands run through most of these themes. First is the importance of trying to establish the historical basis of dynamism in agrodiversity, its adaptation and innovations. Second is the use and management of the biophysical diversity in the land.
\end{abstract}

(Brookfield 2001: 54, 55, 140, 57)

Brookfield's comments about farmers would seem unexceptionable to geographers and anthropologists who have lived in and come to know the landscapes of smallholders in the tropics. High modernists and many development specialists might accept that smallholder farmers plant trees within their territories, but would baulk at Brookfield's further argument that the landscapes in question have long been subject to a dynamic management where 'nature' and human productive activities are not antithetical. In such smallholder landscapes the farmers - though often tagged 'traditional' - are constantly experimenting and learning and then modifying their productive technologies. Adaptation - development perhaps - has been and is going on all the time. And today, the changes most useful to smallholders still arise largely from local initiative, not from external projects.

The particular aspect of tropical landscapes that we examine in this chapter is the humanization of forests, a process that creates Brookfield's 'cultivated forests'. But that term does not imply stasis because on any particular site there is a shifting and merging over time of different sorts of vegetation, each subject to different degrees of management. The focus of this chapter is the South-West Pacific, but similar productive techniques are found throughout the tropical world. The chapter 
begins with examples of the management of productive landscapes in which trees are an integral part. That these examples are drawn from ethnographic and ethnobotanical rather than agricultural or agronomic sources is significant but not surprising. The subsequent focus on Papua New Guinea shows the widespread importance there of a range of tree crops and the diverse practices by which they are managed and integrated with other components of systems of production. Consequently, the recurrent associations among particular useful tree species, far from being happy accidents of provident nature, are the result of long-term selection and deliberate agricultural practice, extending beyond the confines of the 'garden' in both space and time.

\section{Traditional agroforestry}

It remains generally the case that land occupied by something called 'forest' is seen by Westerners to be segregated functionally and conceptually from land occupied by something called 'field' or 'garden', the latter term having special salience in the Pacific (Bayliss-Smith et al. 2003; Dwyer 1996: 176; Hviding and Bayliss-Smith 2000: 23). That there are intimate connections between the two is not, however, a new idea. Writing more than sixty years ago about the island of Tikopia, Solomon Islands, Raymond Firth (1936, 1939) revealed how it only slowly became evident to him that rather than being 'heavily wooded with small and infrequent patches of cultivation in the neighbourhood of scattered villages' the whole of Tikopia:

is in a high state of economic utilization, that gardens are made right up the mountain, and that what appears to be bush is really a collection of trees and shrubs, each having its own value to the people, either for its food or in their material arts.

(Firth 1936: 374-75).

Nearly fifty years later, Kirch and Yen elaborated on Firth's observations on Tikopia, noting that the:

terrestrial environment of Tikopia is virtually its agricultural system. Its forestlike canopy, from the shorelines to the ridges and summits of the volcanic massifs of the incomplete crater rim, acts as a camouflage of the 'high state of economic utilization'.

(Kirch and Yen 1982: 25)

Barrau (1955, 1956) and Yen (1974) both stressed the significance of tree crops in the Pacific decades ago. Yen's landmark exposition of cultivated status in Santa Cruz (Solomon Islands) focused on many tree crops otherwise described as gathered or wild in Melanesia, and on the integration of tree and field crops. Yam gardens might be turned into 'breadfruit plantations', village gardens were virtually tree gardens and roadside trees were planted. Transplanted or tended seedlings marked by twigs were ubiquitous. Arboriculture, at first sight a haphazard 
enterprise conducted by men with minimal investment of labour, in contrast to fields maintained by women, nevertheless made a considerable contribution to subsistence. It was integrated into most forms of agricultural procedure, acting as insurance and stabilizer of the seasonal spread of production, varying diet and aiding hunting and animal husbandry (Yen 1974: 275-78).

Clarke (1971), writing about a Maring community in the Simbai valley in Papua New Guinea, described a flowing process whereby people turn plots of land occupied by aging gardens into orchards of four valued food- and fibre-producing tree species (marita [Pandanus conoideus], Gnetum gnemon, breadfruit and a fig species). The orchards, over decades, slowly melded into secondary fallow, which in turn was eventually cut to make new gardens, with relict cultivated trees serving to validate rights of use by a man whose father or grandfather planted the trees.

A further example of the integration of trees and garden is provided by McEldowney (1995: 97-147), who found twenty-three taxa of tree crops (seventeen of them fruit- or nut-bearing) prominent across the landscape of Baluan Island in Manus Province, Papua New Guinea. All twenty-three taxa were present in the three spatially distinct arboreal assemblages: village tree gardens (growing within the active settlement grounds), orchards (dense, structurally diverse plant communities outside of settlements) and valued tree crops scattered throughout the gardened land.

On Fergusson Island, in Milne Bay, Flavelle similarly described 'a complex polyphase agroforestry system ... [of which] the vegetation phases are ecologically integrated in both space and time' (1991: 111), which provided a continuous harvest of products. Fruit and nut trees and species used for medicine and construction were tended or transplanted in fallow yam gardens, and grew at higher densities close to the coastal hamlets, forming a nearly continuous coastal ribbon. More or less pure stands of betelnut and coconut were planted, as were more mixed sago groves (1991: 56-61). Domesticated or maintained trees (the nut-bearing Pangium edule and species of mid- and high-elevation Pandanus) within a forest territory are integrated into everyday sociability as well as into ritual life, well described for two Papua New Guinea highland populations (Bonnemère and Lemonnier 2002; Kelly 1993).

In another part of Papua New Guinea, people around Amanab, in the Border Mountains of West Sepik (Sandaun) Province, combine the planting of root and tree crops, including sago, their main staple (Huber 1977; Juillerat 1982, 1984). Similarly, the Anggor-speaking people, who live south of Amanab, are neither primarily sago workers nor primarily gardeners; both activities are integrated into a single pattern of landscape management (Huber 1977). Outside observers may see sago working as peripheral and casual because the sago palms occur in isolated, dispersed stands and sago working can be taken up or dropped at any time. Gardening of tubers and other crops may be seen as peripheral because sago is the people's commonest food and they cultivate only a small area of land compared with many other Papua New Guineans. But in the land planted to gardens, as among the Maring mentioned above, maturing annual crops are replaced by orchards, the components of which include breadfruit, nuts, marita pandanus and, 
most importantly, Gnetum gnemon (tulip in Tok Pisin), the leaves of which are the common accompaniment of sago, the staple of the diet. The primary goal of creating gardens is not the production of short-term crops but the long-term management of orchards. The taro, bananas and other garden crops are a pleasant dietary supplement. Huber further suggests that 'management' is the wrong word because, as commonly used, the word refers to a technical process, separated from the rest of life. In terms of the dichotomies of garden/forest, work/social life and management/absence-of-regulation, the daily activities of people like the Anggor remain a puzzle.

Slow as these studies in ethnography and ethnobotany have been to penetrate the contemporary milieu of economic- and sustainable-development activities, there are signs of a lessening in the contrast between the productivity of trees or forest, on the one hand, and gardens or fields on the other. Influential in this change is the work of Harold Brookfield, notably his chapter 'Managing Plants in the Fallow and the Forest' in Exploring Agrodiversity (Brookfield 2001). Brookfield reviews some of the large body of work from Latin America, and the more limited work from Asia, on managed successional fallows. He looks too at 'complex multistorey agroforests' in South-East Asia and asks with regard to various manipulations of vegetation: 'What is natural and what is human-made?', and concludes that until very recently, fields and crops were the domain of agricultural science and trees were the domain of forestry. By contrast, farmers do not draw a distinction between trees and crops; they treat the whole farming space as one, thus providing an integration of field and wood that is central to agrodiversity as well as to soil-fertility management and erosion prevention.

Elaborated systems of fallow and forest management in conjunction with gardens and field crops are not only widely in use today, they are also ancient. Perhaps the broadest evidence for this assertion comes from Amazonia, an area of forest often assumed to be 'virgin'. Smith et al. (1995) reviewed various studies to conclude that many of the forests of tropical America, including the Amazon, are anthropogenic, having been subject to sporadic clearing and enrichment with valued species over many thousands of years, thus challenging this 'myth of virginity'. Indeed, such was the enhancement of forest with useful products prior to European entry that following the great population decline in Amazonia after that entry some peoples gave up farming entirely and gained a livelihood through hunting and from gathering foods on migratory treks - using the resources created by formerly agricultural peoples (Brookfield 2001: 142).

The many studies of Amazonian and other forests (Brookfield 2001; McConnell 2003; Smith et al. 1995) all point to sophisticated and complex manipulations of short-term crops and trees, involving such things as mulching, using the ash from specific trees to enhance the growth of specific plants, transplanting, or managing complicated sequences of shifting cultivation far removed from the simple concept of chop forest/burn debris/plant crops/'abandon' garden site to natural fallow. Although details and levels of intensity may differ, none of this is alien to Melanesian landscapes and their management.

For another part of the world, Fairhead and Leach (1996) meticulously 
demonstrated how village people in the transitional forest-savanna zone of Guinea in West Africa have created, within open expanses of grassy savanna, patches of dense, verdant, semi-deciduous rainforest. These forest islands are generally circular, a kilometre or two in diameter. Most of the forest islands contain a village at their centre. Aside from the forest islands, dense forest is found only along stream sides or swampy valley bottoms. Since the first French occupation in 1893, Guinea's administrators were convinced that the forest patches were the relics of an original dense humid forest that once covered the whole landscape, and that the inhabitants had progressively converted this forest into savanna through their shifting cultivation and fire-setting practices, preserving only narrow belts of forest around their villages. Village elders bluntly reversed this institutional orthodoxy, saying that their landscape was filling with forest, not emptying of it, a view that Fairhead and Leach (1996) convincingly demonstrated through historical analysis, local study and air photographs. In short, forest islands are not relics of destruction but were formed in savanna by villagers or their ancestors. Moreover, the forest islands are growing even as population density has increased, as villagers actively enrich the diversity of their forest by planting, transplanting and encouraging desired plants. The forest species provide a range of useful materials, and the forest itself offers significant advantages, such as fire protection and a shelter for tree crops such as coffee, cola and fruit trees that could not survive in the savanna. Villagers encourage the islands to develop and expand, to some extent by planting but more by fire management and by creating soil conditions that encourage forest development at the savanna edge.

This African example meshes with a view expressed by Hviding and BaylissSmith based on the Marovo lagoon, Solomon Islands, where they argue that the:

'horticultural' view of the Melanesians as 'gardeners' may have dominated the overall ethnographic view of Island Melanesian agriculture and obscured the complex and finely-tuned, short- and long-term interrelationships between root crop gardens under cultivation and the surrounding fallows and forests.

(Hviding and Bayliss-Smith 2000: 23)

Around the Marovo Lagoon, secondary growth of old and recent fallows forms part of the continuous harvest of crops. Shifting cultivation systems (yam, taro, sweet potato, cassava) interact closely with the surrounding forest. Older secondary growth contains a great variety of medicinal plants and other useful trees and shrubs, some of which are planted and others part of regrowth succession. The tall, mature and less disturbed forest is part of the agroforestry complex, containing planted groves of two species of Canarium nut trees, which remain fundamentally important in Marovo people's lives. Their importance is evident by the universal use in Marovo of the word buruburu (the word for Canarium nut tree) for 'year' as the time between each Canarium harvest. Moreover, Canarium nuts have now shifted from their traditional use in inter-island networks of ceremonial exchange to become prized commodities for urban markets. 
Marovo people categorize every part of their total environment, and conceptualize forest as both domesticated and 'wild', the latter word being interpreted to mean no longer under explicit human control (Hviding and Bayliss-Smith 2000: 49). There is also a term for tracts of forest that people agree have been left uncut for something like fifty years but that show signs of previous cultivation and habitation, such as stone terraces for taro irrigation, Canarium groves and Areca palms. The planted trees and garden remnants are known to have been built or planted by certain named persons. As is often now the case in Melanesia, landdispute cases require knowledge of such ancestral connections, and people can be challenged to display their rights by locating old trees and relating them convincingly to a known ancestor.

\section{Tree crops and agriculture in the New Guinea region}

While the importance of tree crops in the South-West Pacific has long been recognized, the great diversity of these is less commonly appreciated. Papua New Guinea exemplifies this diversity, which encompasses both crops unknown beyond the region, such as the upland Pandanus species of New Guinea, and unfamiliar uses and varieties of well-known species, such as the nearly ubiquitous preference of Papua New Guineans for the seeds rather than the flesh of breadfruit. Table 5.1 lists the tree crops recorded in more than one province by the Mapping Agricultural Systems of Papua New Guinea Project (MASP) (Bourke et al. 1998). The presence of each taxon is shown as a percentage of the number of agricultural systems in each province, thus indicating distribution both within and between provinces. Because of MASP's emphasis on recording crops that make a significant contribution to subsistence rather than providing a complete inventory, the list is far from exhaustive.

Tree crops provide significant staples, as well as supplementary greens, fruit and nuts, throughout the country. All of the staples, half of the greens and nuts and a third of the fruit in Table 5.1 are significant foods in at least two-thirds of the provinces. Tree crop diversity is somewhat less in the Highlands provinces, where land is more intensively gardened and there is less forest. Tree crops are grown in widely different contexts, ranging from montane to lowland and coastal forest, grassland and bush fallow, swamps, roadsides, village and hamlet environs, strands and coral islets. They occur as widely scattered individual trees in both forests and gardens, and as plantations or orchards of both single and mixed species. Recently introduced fruit species are widely distributed.

A notable characteristic of the arboriculture of both mainland New Guinea and the smaller eastern Melanesian islands is that similar assemblages have a very widespread occurrence, with, for instance, breadfruit, Canarium and Pometia widely associated in the islands and also in the Torricelli Mountains on the mainland. Similarly, sago, breadfruit and Gnetum occur together in many places. But the assemblages also vary, with Gnetum strongly associated with Pandanus conoideus in the Simbai Valley, where there is no sago. The widespread occurrence of these similar assemblages of trees, many of them of probable New Guinean origin, suggests both 


\begin{tabular}{|c|c|c|c|c|}
\hline 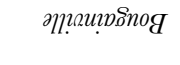 & $\theta$ & $88=$ & H̊ O & 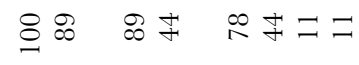 \\
\hline и!рұй мал $\mathcal{N} M$ & $\stackrel{\infty}{\sim}$ & ஓた口 & 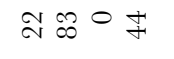 & 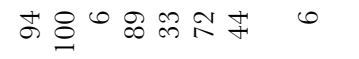 \\
\hline 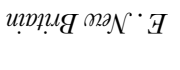 & 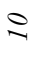 & $8 \&$ & 으요으우 & ஃ \&ㅇㅇㅇㅇ \\
\hline ритрац па & 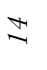 & 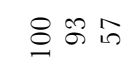 & - & 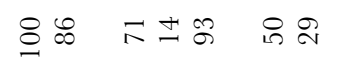 \\
\hline${ }^{\text {snup}} W$ & $\wedge$ & $8 \&$ in & $\pm ネ$ & 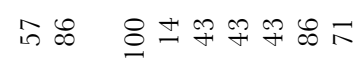 \\
\hline unvpups & 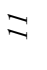 & 8 윰ำ & ț용 & 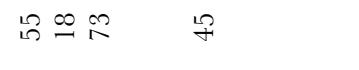 \\
\hline צュd & $\stackrel{2}{2}$ & 용 & $8 \stackrel{\circ}{\circ}$ & 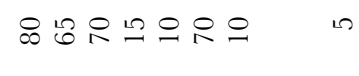 \\
\hline${ }_{\text {Suppv } W}$ & के & $88 \mathrm{in}$ & in 0 & 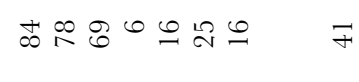 \\
\hline $290.10 \mathrm{~W}$ & i & $\mathscr{\sigma} \stackrel{\infty}{\infty} \stackrel{\infty}{\sim}$ & $\stackrel{\mathscr{c}}{\sim} \stackrel{\infty}{\sim}$ & 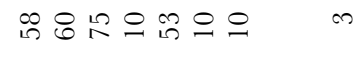 \\
\hline 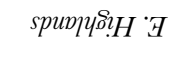 & $\stackrel{\pi}{2}$ & $8^{++}$ & $\infty 0$ & $=\infty$ gू $\quad+$ \\
\hline nques & 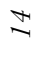 & $\oslash \quad \pm$ & $\Xi む$ & $\stackrel{m}{\rightarrow} \subseteq$ \\
\hline spum ${ }^{\rho} ! H \cdot M$ & $\cong$ & ने $\infty$ & ํㅗำ & $\hat{6}=\stackrel{\infty}{r} \infty$ \\
\hline pos $u_{\text {马 }}$ & $\approx$ & $\infty \stackrel{2}{\infty}$ & & $\infty$ \\
\hline spumly? $! H: S$ & $\approx$ & $\widehat{\infty} \cong$ & or & $g+b+\infty+$ \\
\hline${ }^{0.0} O$ & $\approx$ & $8 \approx \tilde{\sigma}$ & ชิ ถึ & 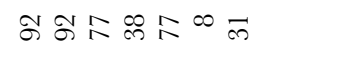 \\
\hline «в дич! & के & $8 \widehat{\infty} \stackrel{m}{m}$ & $\infty$ & 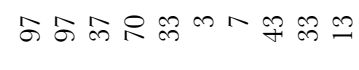 \\
\hline рияиау & શे & $8 \underset{ }{\infty}$ & 字 ले & 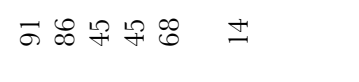 \\
\hline$f i n$ & 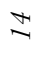 & $8 \stackrel{9}{+}$ & in $\stackrel{m}{+}$ & ț \\
\hline uцәэsә M & 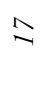 & $8: 8 \infty$ & $\stackrel{1}{2} 0$ & 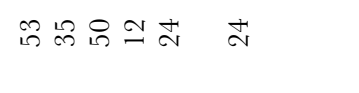 \\
\hline & 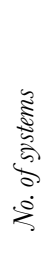 & 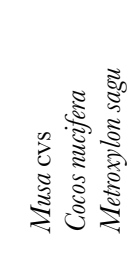 & 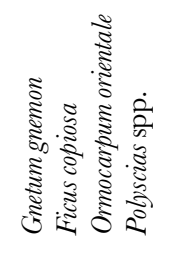 & 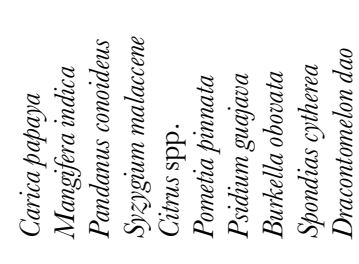 \\
\hline & & 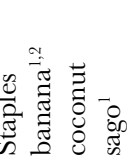 & 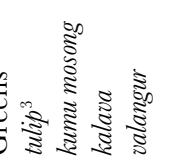 & 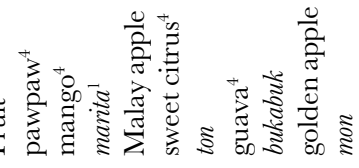 \\
\hline
\end{tabular}




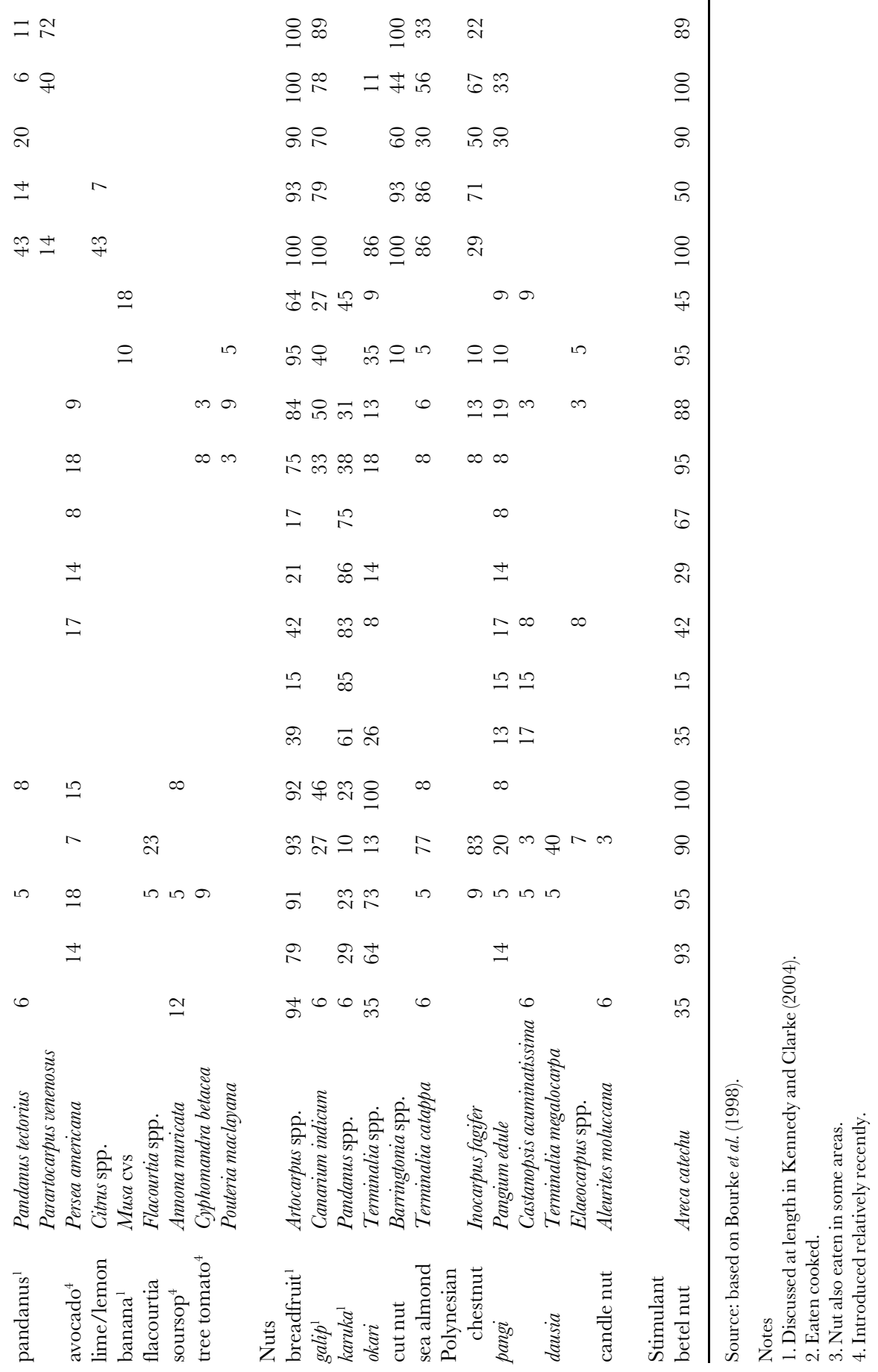


the antiquity of arboriculture and its indigenous, rather than introduced, origin in Melanesia.

Terms such as arboriculture and agroforestry, orchard and plantation, garden and field, horticulture and agriculture have previously been used without defining them. All imply domesticated rather than wild resources. We follow Brookfield (2001: xv) and Purseglove (1974: 1) and disregard the distinction between horticulture and agriculture, as horticulture in the Pacific is often used as a synonym for agriculture. Agriculture is used as an inclusive cover term for productive activities, of which the other terms describe specific components. Although some of these terms have been taken to imply stages in the development of agriculture, the generality of such models is problematic and, as Brookfield (2001: 64) makes clear, they do not help us understand the great diversity of management practices among present-day small farmers. Following the ethnobotanical work of Barrau (e.g. 1955, 1956, 1963, 1976) and Yen (e.g. 1974, 1982, 1985, 1991, 1993, 1996), we argue that the agriculture of the wider New Guinea region is distinguished particularly by the incorporation of tree crops. Evidence bearing on the historical basis of this incorporation and the problems of distinguishing indigenous and introduced practices and species is reviewed elsewhere (Kennedy and Clarke 2004).

Just as foraging, cultivation and agriculture may be represented as a continuum, so wild, tended, planted and cloned may be represented as stages in a continuing process of plant domestication; these stages then standing as indices of the continuum from foraging to agriculture (Harris 1996: 444-47; Hope et al. 1983: 42). However, the cultivated or wild status of New Guinea tree crops is the source of much confusion (Matthews and Gosden 1997: 129-31). Part of this confusion arises from the application to trees of criteria and concepts defining cultivation or domestication that apply more comfortably to life forms with much shorter life spans. Ingold (2000: 86) points out that the 'relative scope of human involvement in establishing the conditions of growth ... is not only a matter of degree rather than kind, it can also vary over time' (original emphasis). Thus, 'the temporal interlocking of the life-cycles of human, animal and plants, and their relative durations' are a crucial variable. Ingold's argument here extends Rival's insight, that the notion of human intervention controlling the life cycles of species with slower growth and maturation cycles than humans is tenuous, and for long-lived tree species becomes untenable (Rival 1993).

In much of the literature on New Guinea subsistence, the basis for describing particular tree crops as wild or cultivated is left quite unclear. Although recorded cultivation practices include planting seeds, transplanting seedlings and suckers, protection and selective weeding, descriptions are rare and scattered. Reports of active planting are often overlooked, and planting is undoubtedly underreported. Trees are often assumed to be wild because they grow in forest that appears to be undisturbed, while the same species growing in village environs may be described as cultivated or semi-domesticated. Some species, such as coconuts and breadfruit, are much more likely to be assigned to the cultivated domain than are less familiar species such as marita (Pandanus conoideus) or sago. Nevertheless, landscape contexts that incorporate undoubtedly planted tree crops, including montane, lowland 
and coastal forests, bush fallows, swamps, strands and coral islets, are all commonly mistaken in the literature for unmodified natural habitats, the domains of foraging.

If domestication is defined as 'genetic and/or phenotypic selection [that] has led to morphological change and a degree of dependence on human actions for the plant's survival' (Harris 1996: 446), marita, which lacks viable seeds and is propagated vegetatively, is a fully domesticated cultigen. The genetic status of breadfruit and sago in much of New Guinea is much less clear-cut, but both are undoubtedly the subjects of active and intentional human selective pressures. As Yen (1990) makes clear, identifying the degree to which a particular plant species is under genetic control is no simple matter, and it has no necessary relationship to the degree of human intervention in the growth conditions of an individual specimen. Since contemporary New Guinean agricultural systems characteristically incorporate wild forms of progenitor species in genetic exchange with domesticated forms (Yen 1990: 566), it is inappropriate to regard domestication as a qualitative state at one end of a continuum. But the fact that interchange between wild and domesticated forms continues in some components of Papua New Guinean agricultural systems does not warrant description of these components as somehow less than domesticated. Domestication may not be a useful quantitative index of whole agricultural systems, especially those that are not dominated by annual seed plants and short-lived annuals. Furthermore, it is difficult to define a qualitative set of criteria that subsume the effects of active human selection on the wide range of life forms with which humans interact. The complexities of disentangling the wild, cultivated or domesticated status of several tree crop taxa are considerable (Kennedy and Clarke 2004).

In the New Guinea region, the integration of different modes of cultivation of mainly perennial plants in complex polycultural production systems justifies the designation of these systems as agricultural. For the reasons given above, and because landscape management, resource ownership and planning encapsulate such resources as part of the overall system, it makes no sense to segregate parts of these systems as non-agricultural on the grounds that one or more of the plant species involved is wild rather than domesticated or foraged rather than harvested.

\section{Conclusion}

Understanding the complexity of tree assemblages within Melanesian landscapes emphasizes Hviding and Bayliss-Smith's conclusion that none of the English words used to describe Melanesian cultivation practices are wholly satisfactory. For lack of a better word, Hviding and Bayliss-Smith (2000: 17) settle on 'agroforestry' in connection with the use and management of trees, but restrict the term to its indigenous referents rather than to the modern institutional meaning. They favour 'agroforestry' because it:

suggests a functional integration between cultivation practices (including the cultivation of tree crops) and the management of the forest itself. This 
integration not only matches the practice of food production from the land in Marovo and how it is conceptualised locally; it also conforms to current scientific understanding of how these systems of production are maintained.

Hviding and Bayliss-Smith add that although the agricultural activities of the Marovo people may, at first glance, appear to be dominated by garden crops grown after a tree fallow, the secondary growth of old and recent fallow forms part of the continuous crops harvested. Given the wide distribution as well as the time depth of these sorts of practices, a new taxonomy of productive practices is required, that enables an appreciation of the productive capacity of the intricate associations of plants found in Melanesian landscapes.

One conspicuous obstacle to developing such a taxonomy is the prevalence in modern management systems of the segregation of trees and short-term crops one to the domain of forestry, the other to the domain of agronomy. Consequently, it is difficult for managerial practitioners in either field to conceive how both activities can be part of a single integrated system of production. Beyond that, gardens are often considered to be human artifacts (part of culture) that are embedded in forest (part of nature). It then follows that culture and nature are incompatible, whereas human thought and manipulation over generations have woven forest and garden into a single fruitful fabric. More broadly, as Yen (1989) put it, the present landscapes are the result of a long-term 'domestication of the environment' begun by the first occupants, whether these were cultivators or hunters and gatherers.

Related to the bureaucratic segregation of annual crops and trees is the inability of modernist managers and developers to go beyond simple categories that are too coarse to do justice to the actual complexity of natural and social processes. James Scott, writing about why large, state-sponsored development schemes so often fail, comments with regard to agriculture (1998: 262):

The simple 'production and profit' model of agricultural extension and agricultural research has failed in important ways to represent the complex, supple, negotiated objectives of real farmers and their communities. That model has also failed to represent the space in which farmers plant crops - its microclimates, its moisture and water movement, its microrelief, and its local biotic history. Unable to effectively represent the profusion and complexity of real farms and real fields, high-modernist agriculture has often succeeded in radically simplifying those farms and fields so they can be more directly apprehended, controlled, and managed.

It is also difficult for managers who hold such views to accept that ecosystems are contingent and dynamic (Scoones 1999). Economic management, as well as management for 'sustainable development', focuses on stability, whether for maximum production or for steady production over a long term. In contrast, local people see the fluidity of the many ever-shifting parts of their landscapes. They also recognize its 'altogetherness' as they work and walk in it, fine-tuning its bits and pieces. They 
'feel the pulse' of their land. Their concern is less with maximum production than with keeping the productive system turning over. They can allow for fluctuation of production because they have such a variety of resources and fallback capabilities. This variety and the people's knowledge of it give systems resilience, which many now consider a more significant - or meaningful - concept than sustainability.

An irony in the current debate about biodiversity is that vast sums are spent on projects to protect and preserve biodiverse regions by limiting or eliminating human activities. Less attention, or no attention, is paid to how biodiversity may be increased by human action. Such creation of biodiversity occurs at four levels in Melanesian landscapes:

- In whole landscapes: Because these are made patchy by the complex shifting of gardens, orchards and managed fallow, landscapes have an overall structural complexity that offers a variety of habitats. Fox et al. (2000) use an example from Vietnam to explore the effects on biodiversity and other ecological characteristics of the change from what may have been a fairly homogeneous forest to a more heterogeneous and fragmented cover of secondary vegetation.

- Locally: Biodiversity is encouraged by the variety of niches in the transition zones between types of vegetation.

- In crop assemblages, including trees: New associations among plant species are created by interplanting of different crops, by management of successions from garden to fallow or orchard and by the alteration of forest composition by interventions such as selective weeding.

- In the genetic diversity of individual crops, including trees: Because of constant selection and distribution by past generations of tropical cultivators, a wide diversity of cultivars or varieties has been created, as is demonstrated in the preceding discussion and in many ethnographic sources (e.g. Kocher Schmid 1991, 1998). The potential genetic diversity of some cultivars is further enhanced because their wild counterparts are also conserved.

Perhaps the cultivated Melanesian landscapes we are concerned with are an anachronism in today's world. Perhaps they cannot be appreciated because it takes too long for outsiders to come to recognize the subtle character of their productive worth. And there are too few detailed studies of what might be called landscape ecology. There are considerable conceptual difficulties in developing models that encompass the very different scales and criteria of definition by which landscapes and various component systems of land use may be described.

It can of course be argued that Melanesian cultivated landscapes - which have no legally delineated individual rights of ownership, which feature such a finegrained structure of diverse plants and fecundity both temporally and spatially, and which are not designed for monocultural maximization - do indeed have no place in the world today. To modern eyes there may seem to be no way to exploit cultivated landscapes except through their transformation to other forms of production that better fit the contemporary scheme of things. Nonetheless, to lose landscapes 
that have for so long embodied so much human thought, that are so strategically managed and that have provided a heterogeneous sustenance for generations of people would be a tragedy.

While not always being aware of what may be lost, development enthusiasts in rural areas often face a long-standing puzzle in that when local people are offered a project based on the commercial production of a crop that will increase income locally while also acting to boost national development, they may not seem eager to take up the work required or only take it up at the low level necessary to bring in enough cash to meet a few vital needs. A long-standing explanation for this situation in Melanesia is that people living in resources-rich landscapes such as we have described are in a state approaching 'subsistence affluence'. Their economy is not limited by resource shortages; in fact, it could be argued that they underuse their resources. As Huber (1977: 4) wrote, the general problem of rural development in Papua New Guinea is one of finding ways to increase the use of local resources by increasing the application of labour in such a way that any surplus production that results can be channelled into the national economy and any changes that this brings about will not undermine the self-reliance of the local communities.

What may look like 'laziness' is not an attempt by people to maximize leisure at the expense of productivity (Huber 1977: 10). Rather, rural Melanesians are as eager to convert free time into cash as most rural people throughout the tropics. However, the labour input necessary to manage cultivated landscapes may appear to outsiders to be casual and sporadic, not real work. But it is this pattern of modest activity carried out by people circulating through the landscape that keeps the productive processes working and that is also an integral thread in the fabric of social life. Just as the dichotomy of garden/forest is not applicable, neither is work something separate from social life and sense of community.

\section{References}

Barrau, J (1955) Subsistence Agriculture in Melanesia, Noumea: South Pacific Commission. -(1956) Polynesian and Micronesian Subsistence Agriculture, Noumea: South Pacific Commission.

(ed.) (1963) Plants and the Migrations of Pacific Peoples: A Symposium. Honolulu, HI: Bishop Museum Press.

-(1976) Breadfruit and Relatives. Artocarpus spp. (Moraceae), in N W Simmonds (ed.), Evolution of Crop Plants, London: Longman, pp. 201-2.

Bayliss-Smith, T, Hviding, T and Whitmore, T (2003) Rainforest Composition and Histories of Human Disturbance in Solomon Islands, Ambio, 32, 346-52.

Bonnemère, P and Lemonnier, P (2002) Two Anga Vegeculture Systems in New Guinea: Technical and Cultural Specificities in the Utilization of Some Seasonal Trees, in S Yoshida and P Matthews (eds), Vegeculture in Eastern Asia and Oceania, Osaka: National Museum of Ethnology, pp. 247-64.

Bourke, R, Allen, B, Hobsbawn, P and Conway, J (1998) Papua New Guinea: Text Summaries. Agricultural Systems of Papua New Guinea Working Paper 1. Canberra: Department of Human Geography, Research School of Pacific and Asian Studies, The Australian National University. 
Brookfield, H (2001) Exploring Agrodiversity, New York: Columbia University Press.

Clarke, W G (1971) Place and People: An Ecology of a New Guinean Community, Canberra: Australian National University Press.

Dwyer, P (1996) The invention of Nature, in R Ellen and K Fukui (eds), Redefining Nature: Ecology, Culture and Domestication, Berg: Oxford, pp. 157-86.

Fairhead, J and Leach, M (1996) Misreading the African Landscape: Society and Ecology in a Forestsavanna Mosaic, Cambridge: Cambridge University Press.

Firth, R (1936) We, The Tikopia: A Sociological Study of Kinship in Primitive Polynesia, London: Allen \& Unwin.

- (1939) Primitive Polynesian Economy, London: Routledge \& Kegan Paul.

Flavelle, A (1991) A Traditional Agroforestry Landscape on Fergusson Island, Papua New Guinea, unpublished MSc thesis, Department of Forest Resources Management, University of British Columbia.

Fox, J, Truong, D M, Rambo, A T, Tuyen N P, Guc L T and Leisz S (2000) Shifting Cultivation: A New Old Paradigm for Managing Tropical Forests, BioScience, 5, 521-28.

Harris, D (1996) Domesticatory Relationships of People, Plants and Animals, in R Ellen and K Fukui (eds), Redefining Nature: Ecology, Culture and Domestication, Berg: Oxford, pp. 437-63.

Hope, G, Golson, J and Allen F J (1983) Palaeoecology and Prehistory in New Guinea, Fournal of Human Evolution, 12, 37-60.

Huber, P (1977) Traditional Land Use in Papua New Guinea: Anthropology and Rural Development, Discussion Paper 26, Port Moresby: Institute of Papua New Guinea Studies.

Hviding, E and Bayliss-Smith T (2000) Islands of Rainforest: Agroforestry, Logging and Eco-tourism in Solomon Islands, Aldershot: Ashgate.

Ingold, T (2000) The Perception of the Environment: Essays on Livelihood, Dwelling and Skill, London: Routledge.

Juillerat, B (1982) Note sur les Rapports de Production dans l'Horticulture-arboriculture Yafar (Nouvelle-Guinée), Fournal d'Agriculture Traditionelle et de Botanique Appliquée, 29, 285-93.

- (1984) D'Acorus à Zingiber: Taxinomie et Usages des Plantes Cultivées chez les Yafar de Nouvelle-Guinée, Fournal d'Agriculture Traditionelle et de Botanique Appliquée, 31, 3-31.

Kelly, R (1993) Constructing Inequality: The Fabrication of a Hierarchy of Virtue Among the Etoro. Ann Arbor, IL: University of Michigan Press.

Kennedy, J and Clarke, W C (2004) Cultivated Landscapes of the Southwest Pacific. Working Paper 50, Canberra: Resource Management in Asia Pacific Program, Research School of Pacific and Asian Studies, Australian National University.

Kirch, P and Yen, D (1982) Tikopia: The Prehistory and Ecology of a Polynesian Outlier, Bishop Museum Bulletin 238, Honolulu, HI: Bernice P. Bishop Museum.

Kocher Schmid, G (1991) Of People and Plants: A Botanical Ethnography of Nokopo Village, Madang and Morobe Provinces, Papua New Guinea, Basel: Ethnologisches Seminar der Universität und Museum für Völkerkunde (Basler Beiträge zur Ethnologie, Band 33).

- (1998) The Cultural Importance of Floristic Diversity: A Case Study from Nokopo Village, Madang and Morobe Provinces, Papua New Guinea. Worldviews: Environment, Culture, Religion, 2, 107-22.

McConnell, D (2003) The Forest Farms of Kandy and other Gardens of Complete Design, Aldershot: Ashgate.

McEldowney, P (1995) Subsistence Intensification in the Late Prehistory of Manus, unpublished PhD Thesis, Canberra: Australian National University.

Matthews, PJ and Gosden, C (1997) Plant Remains from Waterlogged Sites in the Arawe 
Islands, West New Britain Province, Papua New Guinea: Implications for the History of Plant Use and Domestication, Economic Botany, 51, 121-33.

Purseglove, J (1974) Tropical Crops: Dicotyledons, New York: Halsted Press.

Rival, L (1993) The Growth of Family Trees: Understanding Huaorani Perceptions of the Forest, Man, 28, 635-52.

Scoones, I (1999) New Ecology and the Social Sciences: What Prospects for a Fruitful Engagement? Annual Review of Anthropology, 28, 479-507.

Scott, J (1998) Seeing Like a State: How Certain Schemes to Improve the Human Condition Have Failed, New Haven, CT: Yale University Press.

Smith, N, Serrão, E, Alvim, P and Falesi, I (1995) Amazonia: Resiliency and Dynamism of the Land and Its People, UNU Studies on Critical Environmental Regions, Tokyo: United Nations University Press.

Yen, D (1974) Arboriculture in the Subsistence of Santa Cruz, Solomon Islands. Economic Botany, 28, 247-84.

- (1982) The History of Cultivated Plants, in R J May and H Nelson (eds), Melanesia: Beyond Diversity, Canberra: Research School of Pacific Studies, Australian National University, pp. 281-95.

_ (1985) Wild Plants and Domestication in Pacific Islands, in V N Misra and P Bellwood (eds), Recent Advances in Indo-Pacific Prehistory, New Delhi: Oxford and IBH Publishing, pp. 315-26.

-(1989) The Domestication of Environment, in D Harris and G Hillman (eds), Foraging and Farming: The Evolution of Plant Exploitation, London: Unwin Hyman, pp. 55-75.

-(1990) Environment, Agriculture and the Colonisation of the Pacific, in D Yen and J Mummery (eds), Pacific Production Systems: Approaches to Economic Prehistory, Occasional Papers in Prehistory 18, Canberra: Department of Prehistory, Research School of Pacific Studies, Australian National University, pp. 258-77.

(1991) Domestication: The Lessons from New Guinea, in A Pawley (ed.), Man and a Half: Essays in Pacific Anthropology and Ethnobiology in Honour of Ralph Bulmer, Polynesian Society Memoir 48, Auckland: The Polynesian Society, pp. 558-69.

-(1993) The Origins of Subsistence Agriculture in Oceania and the Potential for Future Tropical Food Crops, Economic Botany, 47, 3-14.

-(1996) Melanesian Arboriculture: Historical Perspectives with Emphasis on the Genus Canarium, in M Stevens, R Bourke and B Evans (eds) South Pacific Indigenous Nuts, ACIAR Proceedings 69, Canberra: ACIAR, pp. 36-4. 


\title{
6 Land reform and the state in Vietnam's northwestern mountains
}

\author{
Thomas Sikor ${ }^{1}$
}

We also derive from political economy a concern with the role of the state.

(Blaikie and Brookfield 1987: 19)

A key element in Piers Blaikie and Harold Brookfield's 'regional political ecology' is the notion of marginality, while they further suggest that economic, ecological and political-economic marginality are interconnected in a vicious cycle and that the state assumes a key role in these interactions, discriminating against marginal people and places (Blaikie and Brookfield 1987: 19-23, 17). This chapter subjects Blaikie and Brookfield's theoretical propositions to empirical testing by way of a case study from Vietnam. Vietnam provides fertile grounds for examining the role of the state in 'regional political ecology'. Not only does the Vietnamese government continue to proclaim adherence to socialist goals, but also the exercise of state power has undergone drastic change over the past decade and a half. Within a few years the Vietnamese state has radically repositioned itself towards rural people and places in a manner that promises to highlight usually hidden processes of domination and marginalization.

Vietnamese land reform is here used as a lens to examine the relations between the state and marginal people and places. Land reform has been a cornerstone in the doi moi policy, initiated by the Vietnamese government in the late 1980s (Fforde and deVylder 1996; Tran 1998). In the 1960s and 1970s, the Vietnamese state promoted agricultural producer cooperatives as the way to organize rural labour and capture agricultural surplus. The state's efforts concentrated on getting rural producers to form cooperatives and channelling agricultural products into urban areas via administrative means. In the late 1980s, however, the state abandoned the collectivization drive and state procurement system and intensified efforts to strengthen its control over land. These efforts reached their peak with the 1993 Land Law, which initiated a nationwide programme of land allocation.

Vandergeest and Peluso (1995) coined the term 'internal territorialization' to refer to this process of state control moving from labour and products to space, and observed that many modern states increasingly employed territorial strategies to control people. Strategies are territorial in the sense that modern states attempt to affect, influence or control people through control over space (Sack 1986). States 
classify people and resources by geographical area, and they emphasize and enforce both territorial boundaries and restrictions on activities within the boundaries. The Vietnamese state embarked on such a project in the late 1980s, initiating it at a much later point and pursuing it at a more radical pace than other world states.

This chapter examines how land allocation has been implemented and played out in three villages of Vietnam's northwest, a mountainous region characterized by rugged topography and difficult road access. The inhabitants of the villages are Black Thai, an ethnic minority group numbering around 530,000 concentrated in the northwest. The Black Thai possess their own language and assert a distinct ethnic identity, setting them apart from the majority ethnic Vietnamese (Vien Dan Toc Hoc 1978). The Vietnamese government recognizes the Black Thai as a subgroup of the larger Thai group. The Black Thai in the three villages interact with a neighbouring village inhabited by H'mong, another ethnic group in Vietnam with their own language and history. The H'mong number around 740,000 people in Vietnam and represent the second largest ethnic group in the northwest after the Thai. The northwest and its ethnic minority inhabitants, therefore, appear to represent examples of the marginal people and places discussed by Blaikie and Brookfield in terms of their disadvantageous relations with the state (Blaikie and Brookfield 1987: 113-21).

The chapter begins with a brief historical review of authority relations and the expansion of state power in what is today northwestern Vietnam. The following section takes a closer look at the territorialization project of the Vietnamese state, including national legislation and its implementation in the villages, and the relations between local state agents and villagers. This allows an investigation of people's responses to territorialization and its outcomes in the villages, focusing on contestations over forestry land and rice terraces. The chapter concludes with a discussion of implications for a theory of the state and its relations with marginal people and places.

\section{The expansion of state power in the northwest}

Villagers' personal recollections reach back to the early 1950s. At that time, the villages had existed for many generations as part of the tiny Black Thai principality (muong) Chieng Dong (see Figure 6.1). Tai people ${ }^{2}$ had moved into the mountains of what is today northwestern Vietnam in the first few centuries AD (Wyatt 1984). They had settled in the valleys of the Da river and its numerous tributaries, such as the Vat stream, in whose upper catchment Tai migrants had founded Chieng Dong. The upper catchment provided good conditions for wet-rice agriculture on the valley bottom and dryland cultivation on the lower slopes.

The northwest became dotted with small Black Thai principalities (muong) over the course of centuries (Wyatt 1984; Steinberg 1987; Thongchai 1994). From here on, the term 'Black Thai' is used to refer to one of the two major Tai groups that remained in what is today northwestern Vietnam. The Black Thai today account for the majority of population in Son La province. A typical muong included several 


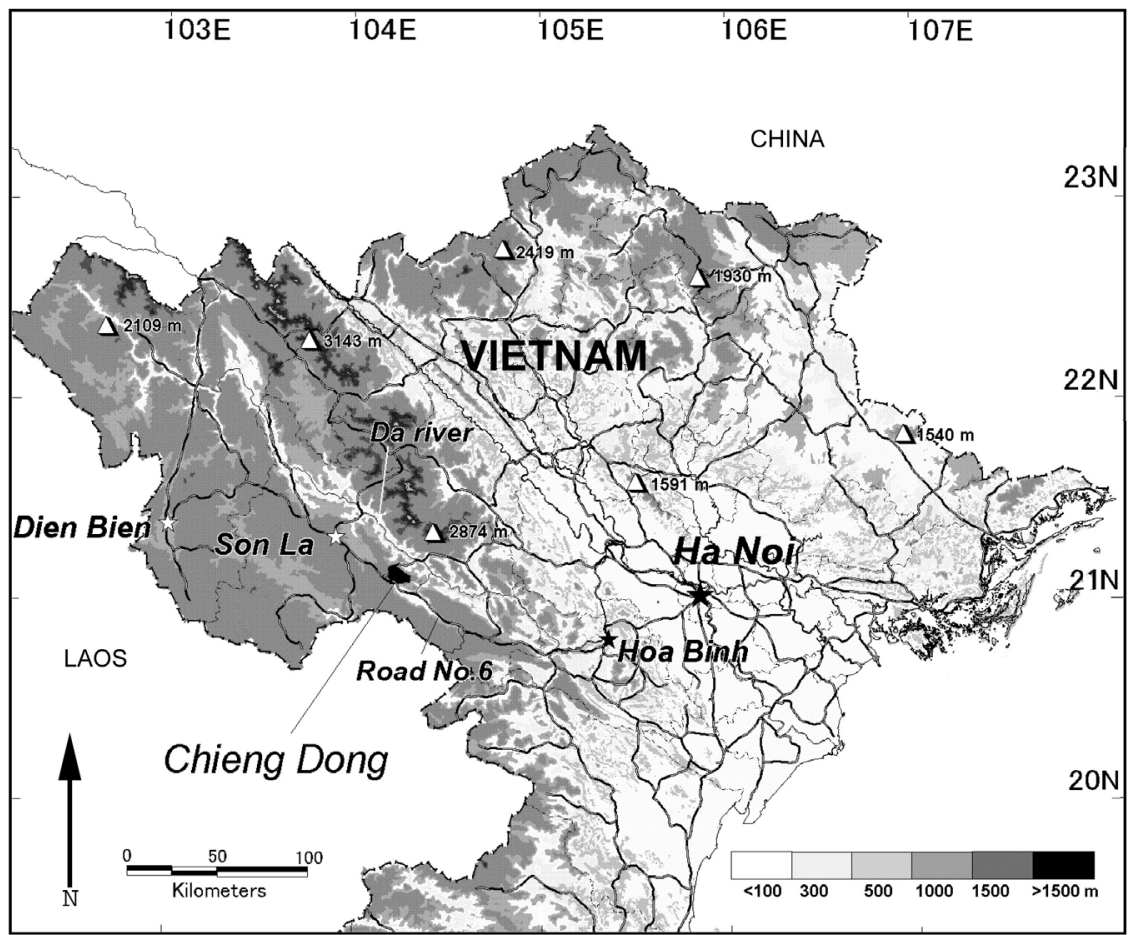

Figure 6.1 Chieng Dong in northwestern Vietnam.

Black Thai villages and possibly villages of other ethnic groups, who had either resided in the region before the Tai migration or came after them. One of the ethnic groups arriving relatively late were the H'mong. Each muong was relatively autonomous in terms of relations to its neighbours and the surrounding powers. The rugged mountain topography and lack of communications infrastructure protected the principalities from any significant control by outsiders. Rather than being marginal in any political structure, they were located in between the surrounding centres of political power.

A muong was ruled by a phia, whose title remained within certain noble Black Thai families (Sevenier 1905; Dang et al. 1977; Cam 1978; Wyatt 1984; Steinberg 1987). The phia and a few notables appointed by the phia enjoyed rights to labour services provided by households or whole villages. The phia also held rights over all paddy fields within a muong, which translated into claims on a share of the rice produced in those fields and symbolic authority over the land. Direct control over paddy land by the phia was limited to a historically defined set of fields worked by his own household using the labour provided by people. The remaining land was under the communal control of villages. This situation appeared quite typical for much of pre-modern Southeast Asia (Vandergeest and Peluso 1995: 392). Rulers levied claims on people's labour and products but made no territorial claims. 
Particular to Black Thai villages was their considerable autonomy (Silvestre 1918; Hickey 1956-58, cited in Lebar et al. 1964; Cam and Huu 1973; Cam 1978). Villages decided the allocation of paddy land, labour duties and tax duties among households. Village control of land focused on the wet-rice fields that villagers had developed historically. The village collectives allocated shares of the paddy to households, and all households in a village had the right to receive part of the village paddy. In return, they had to commit to pay taxes and perform labour duties. In contrast, the villages' territorial control did not extend into the uplands, except where these had been developed for rice terraces. Fields radiated into the uplands surrounding the villages. Once a household had opened up new swiddens it retained use rights to the land, even during extended fallow periods. The fields were exempt from tax or labour obligations. Correspondingly, new migrants, such as the H'mong, faced no significant obstacles to clear unclaimed upland areas for cultivation. This situation did not substantially change after 1888, when the French colonial regime formally included the northwestern mountains into Tonkin, the French overseas territory in northern Vietnam.

In the early 1950s, households in Chieng Dong therefore held use rights to a share of the village paddy and contributed taxes and labour to the local phia just as in any other Black Thai principality. The French had established a military outpost and demanded tax payments and labour services, but had otherwise left the traditional authority system intact. Both French soldiers and the local phia fled the advancing Vietnamese liberation forces in 1952. The villages conducted general redistributions of paddy land in reaction. Control over land was anchored in the villages and limited to wet-rice fields.

After independence, the Vietnamese state initiated efforts to integrate Black Thai villages into the nation state (Chu 1962; Ban 1994). The central government mandated the expansion of the territorially structured administrative system into the mountains. Villages were grouped into communes $(x a)$, the lowest-level unit of state administration. Several communes formed a district (huyen), and in 1962 the central government re-established the province (tinh) of Son La, including around ten districts. Chieng Dong became a commune in Yen Chau district of Son La province. The central government also recruited local Black Thai villagers to staff the newly established local authorities. Black Thai played a predominant role because they accounted for the majority of population in the district, because their leaders had historically ruled over the other ethnic groups, and because parts of the Black Thai had supported the Vietnamese liberation forces in the war against the French (McAlister 1967).

In 1960 the Vietnamese state expanded its drive to collectivize agricultural production into the mountains (Chu 1962; Tran 1968). The villages of Chieng Dong formed cooperatives under the guidance of the district authorities and began to work collectively wet-rice fields and some upland fields in the lower slopes. The cooperatives paid a share of the output to the state as taxes or mandatory sales or in exchange for inputs. They also provided labour to state projects, such as the construction of irrigation canals, and later sent young men for the war in the south. Collectivization was a strategy to control labour and products. 
While the state promoted cooperatives for agricultural production, it reserved forestry to direct state management. A decree in 1955 declared forests to be a national asset, to be managed by state units. 'Forestry land' was supposed to include all land with a slope above 20 degrees, and the term 'forestry land' can be contrasted with 'forest land' to indicate the legal character of the classification. The state mandated that the land, forested or not, had to be used for forestry. The Vietnamese terms dat lam nghiep (forestry land) and dat rung (forested land) express the difference. Large parts of the uplands in Chieng Dong were demarcated as forestry land, despite the fact that people had relied on them for extensive rice swiddening and animal husbandry. The forestry land became subject to legal control by the district administration. Cooperatives had to seek permission from district authorities for the annual location and area of rice swiddens. The authorities also required people to get permits before cutting timber for house construction.

Government efforts facilitated a massive expansion of state power in the northwest. The expansion largely rested on stricter control over labour and products, as implemented through collectivization and state procurement. The state's strategy also included territorial components, particularly the territorially structured state administration and forestry agencies. Yet state territorial control was limited in practice, as evident in Chieng Dong. The district administration could not exclude people from forestry land, as the uplands remained an important source of land for cultivation. By contrast, state control over labour and products proved relatively effective until the late 1970s. The Chieng Dong villages collectivized agricultural production, participated in the state procurement system and provided young men for the war in the south. Once the war was over, however, state control over labour and products eroded rapidly. Villagers increasingly engaged in productive activities outside the collective and marketed a growing share of the surplus outside the state procurement system. ${ }^{3}$

\section{The territorialization project}

\section{National policy and politics}

Territorialization became the main strategy of state control over rural people and resources in the late 1980s. The state abandoned the collectivization project, requiring cooperatives to distribute their land and capital assets to households (Fforde and deVylder 1996; Tran 1998). The state also liberalized markets, terminating state procurement and allowing private traders to operate. The main element of the state's new strategy was the Land Law passed by Vietnam's National Assembly in 1993. The Land Law mandated the state to allocate land under longterm lease arrangements. Allocation allowed the holders of land titles long-term use (20 years for land under annual agricultural crops, 50 years for forestry land) as well as the rights of transfer, mortgage and inheritance. Allocation combined these rights with the obligations to follow the land use prescribed by the state and to pay taxes on land. 
A new specialized government agency, the General Department for Land Administration, put territorial control into practice. The Department was mandated to oversee land allocation, land use planning, the administration of cadastral records, and arbitration in land disputes. It was given resources and staff to establish offices at the provincial and district levels and employ a cadastral cadre at the commune level. The central government also provided funds for land allocation in the provinces. Land allocation exceeded the financial resources normally available to local authorities as it was required to include a cadastral survey, mapping, title registration and the issue of land titles. The expectation was that, with guidance by the Department, local authorities would have classified Vietnam's territory, communicated the classification to people and enforced it within a few years (Sack 1986).

Land use planning became an issue that indicated significant cleavages within the central government. The classification of land for agriculture or forestry was an important issue for the central agencies because the assigned land areas were a primary source of their political authority. The classification had remained unchanged since its introduction, dividing land for agriculture and forestry by degree of slope. The Land Law, and the subsequent Decree 02/1994, therefore heralded a radical change from the past by dropping the rigid classification by slope and decentralizing land use planning to the provincial and district levels. The Ministry of Forestry saw its own authority over two-thirds of Vietnam's territory threatened because much land classified as forestry land had been used for cultivation and grazing. The Ministry was not ready to give up control over forestry land and announced criteria for demarcating forestry land that left little scope for any local interpretation.

The Ministry of Forestry even decided in early 1995 that a large share of forestry land could not be allocated to households for the sake of forest protection. Guidelines contained in Decree 01/1995 allowed households only to receive land use rights for forestry land that was without natural forest, and only if the land was not designated for protection purposes. The Ministry instructed district authorities to allocate land with natural forest and protected forest to state units, which would, in turn, sign contracts with households for forest protection. The contracts reserved all main trees on the protected land for exclusive use by the state. They also included payments to households for their protective activity, payments that absorbed a large share of central government funds for rural areas in the following years. Forest demarcation and protection contracts secured the Ministry of Forestry a continuing share of the national territory and budget. They also implied that most land in the uplands could not be allocated to local people, that the authority to determine appropriate land use remained in the hands of the central government, and control over the products derived from the land that remained in the forest administration. The state's new project, therefore, changed its nature even before leaving Hanoi, and carried the threat of discriminating against upland people and places in the implementation guidelines. 


\section{Land allocation and forest demarcation in Chieng Dong}

The People's Committee of Son La province shared a concern for forest protection with the Ministry of Forestry. When central government funds became available for land allocation in late 1993, the authorities were quick to utilize the territorialization project to strengthen forest protection in the province. They were concerned about forest protection because Son La had become the location of Vietnam's largest hydropower reservoir in the late 1980s and was being considered for another even larger reservoir on the Da river. The first reservoir experienced much higher rates of siltation than had been estimated, forcing the central government to reduce the estimate of its expected lifetime (World Bank 1993). As a consequence, forest protection was considered a priority to protect the costeffectiveness of the past investment and preserve Son La's chances for the future investment.

The provincial authorities instituted strict criteria for the demarcation of forestry land. The top third of each hill and mountain in the province had to be demarcated as forestry land, as well as 80-metre-wide protection belts on each side of national and provincial roads (see Figure 6.2). The provincial authorities limited upland holdings to 2,000 square metres per person, with a maximum of 1.5 hectares per household, thus the provincial ceiling on land holdings remained considerably below the 3 hectares specified by national legislation as the maximum land size. The province initiated other measures to protect forests, including tree planting, the formation of village forest protection and fire prevention groups and the order to stop rice swiddening. They assigned district-level Forest Protection Units a primary role in the execution of the campaign, giving the newly established cadastral offices a secondary role only.

The People's Committee of Yen Chau did not attribute as much priority to forest protection as the provincial authorities. It therefore modified the provincial guidelines in subtle though important ways. Most importantly, the district's guidelines provided a way to get around the land ceiling mandated by the provincial authorities, by granting villages a large area of 'agricultural reserve land'. Households

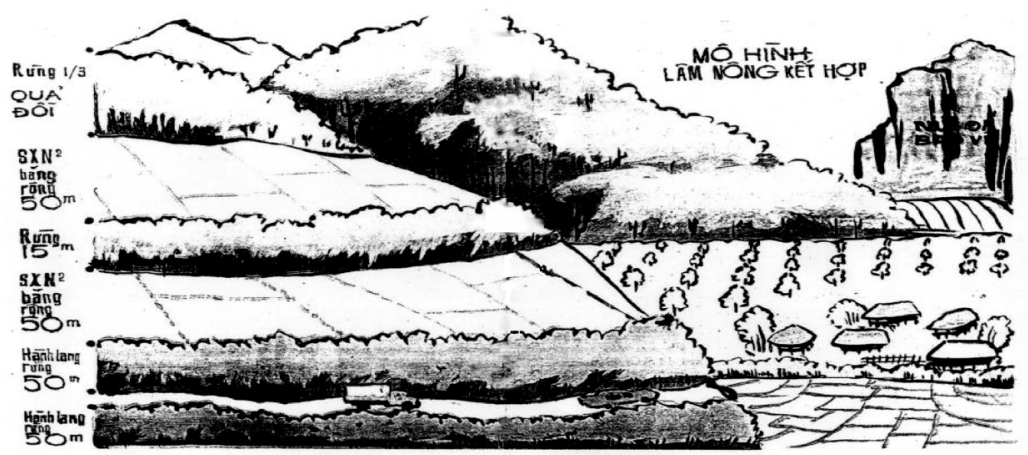

HÃY LÃM THEO MO HINH NÁY!

Figure 6.2 Son La's model for agriculture and forestry, Vietnam. 
would be allowed to 'borrow' part of the reserve land if their landholdings exceeded the land ceiling mandated by the provincial authorities. The district guidelines also ruled out the allocation of agricultural land in a village to people who lived elsewhere.

The campaign gained rapid momentum in the first half of 1994. Within a few weeks, district and commune People's Committees had established steering committees to guide the implementation of the campaign. Numerous district cadres participated in training sessions at the provincial headquarters. The provincial print shop put out 10,000 booklets containing the campaign guidelines. Finally, tree planting kicked off the campaign on May 19, the anniversary of Ho Chi Minh's birthday. The provincial newspaper reported that people had planted more than 100,000 trees in one day. Afterwards, more than a thousand cadres set out to implement the campaign in 70 communes.

The campaign reached Chieng Dong in late June, when a taskforce of district and commune cadres initiated forest demarcation and land allocation. The taskforce organized explanatory meetings with villagers, requested households to register their landholdings to village officials and went out into the field to demarcate forestry land, including sizable areas where villagers had previously worked agricultural fields. The taskforce assigned the forestry land to the villages for protection and required households with fields on the land to abandon them after the cropping season. It then sent the newly appointed commune cadastral officer and village officials into the field to inspect reported fields and estimate their sizes. Finally, the taskforce and households formalized the preliminary allocation in 'land applications' and 'preliminary allocation forms'. Within only a month, the taskforce had completed land allocation in Chieng Dong.

Just as in Chieng Dong, the campaign was largely considered finished in Yen Chau by the end of July. In early August, the district's Steering Committee published its final report, advertising impressive successes. The campaign had zoned 15,000 hectares as forestry land and assigned them to villages for protection. The taskforces had detected more than 2,000 cases of violations against forest protection and had allocated agricultural land to more than 6,000 households in 60 villages. The campaign's outcomes appeared even more successful since it had taken place in the midst of the agricultural season, when villagers were very busy and heavy rainfall made travel to villages and upland areas difficult. Despite these difficulties, thousands of households now held land-use right certificates as visible indicators of the state's territorial claims.

Had the state actually been able to establish territorial control? Did the campaign achieve the reported reduction in the land available for agriculture, promoting the national and provincial goal of forest protection to the detriment of local livelihoods?

\section{A participatory rural appraisal}

Before examining the outcomes of the territorialization project in Chieng Dong, it is useful to have a closer look at the relations between villagers and the state. A 
participatory rural appraisal (PRA) conducted in one village of Chieng Dong revealed processes of negotiation between local state cadres and villagers usually hidden from the view of outsiders. The PRA illustrated how local cadres sought to accommodate both state agendas and village practice, even when in apparent conflict, and shed a different light on the impressive account of state capacity presented in the land allocation report.

District cadres initiated the PRA workshop with the stated goal of identifying the specific needs of the village in the areas of agriculture and forestry. Yet their underlying agenda was to motivate villagers' participation in the planned activities of land use planning, the allocation of forest parcels to households and tree planting. At the end of the two-day workshop, the cadres achieved the results they wanted. The workshop report concluded that people needed to conduct land use planning, take up forest parcels and plant trees. As justification, cadres found that villagers had irrationally degraded local forests, and that deforestation was the primary cause of poverty. The PRA thus reproduced the discourse of deforestation that the provincial authorities had invoked for the forest protection campaign.

Yet considerable evidence casts doubt on the PRA findings. First, the primary source for the history of land use over the past 40 years was a 30 -year-old village official. Together with the district officials, he constructed a history of rapid deforestation and losses in dry season water availability extending far beyond his own lifetime. In contrast, remote imagery indicates that forest cover was not as dense as portrayed by the cadres. ${ }^{4}$ Furthermore, oral histories conducted with village elders and statistical data provided by the district authorities suggest that the village had gradually expanded its wet-rice crop in the dry season, and had never reduced it as claimed in the report. Second, the emphasis on forestry as a strategy to improve household livelihood in the report was in stark contradiction to the actual problems reported by villagers in the household interviews conducted during the workshop. In the original interviews, households emphasized agricultural problems, mainly constraints on wet-rice cultivation, yet in the subsequent meeting with the whole village, the cadres proposed activities that they had already prepared. In the final report, they translated the proposed activities back into a suitable problem definition.

District cadres and village officials jointly produced findings that served the state's agenda. After completion of the PRA the cadres could go about their work as planned. This does not imply, however, that village officials got nothing in return. Village officials successfully managed to deflect the cadres' attention away from practices that conflicted with state policy, notably the now illegal rice swiddening, and made sure that the district cadres took note of their demands for assistance. They expressed these demands in terms of the cadres' agenda, for example by asking for cash payments to support tree planting. They justified their request for the construction of a more permanent irrigation dam not with reference to gains in rice yields but by noting that they could save a lot of wood if they did not have to repair temporary wooden dams after every major flood.

The PRA demonstrated how local government cadres and village officials understood each other's needs and desires, finding ways to attend to both their 
interests. Local government cadres demonstrated 'double loyalty' in their interactions with villagers; they felt compelled to accommodate the interests of central and provincial authorities on the one hand, and of the villagers on the other. Their backgrounds, professional careers and lines of responsibility within the local government located local cadres at the intersection of state and villages (Sikor 2004a). The records produced by them consequently reflected the outcomes of their negotiations with villagers, a story of rapid deforestation that called for the assignment of forest land parcels to villagers under protection contracts. Yet it would be wrong to interpret the records as evidence of local people's discrimination. Underneath the surface of domination were active negotiations between village leaders and local cadres over the state's agenda and villagers' claims on resources. The negotiations happened quite independently from what was reported officially, and continued after the PRA.

\section{The limits of territorialization}

As discussed in the preceding sections, the state's territorialization project had significantly changed its nature by the time it arrived in Chieng Dong. It is useful now to take a closer look at the encounter between the state's project and local land relations, revisiting the district authorities' claims of successful land allocation and forest demarcation. The extent to which the state could enforce the classification documented in the cadastral records can be demonstrated through examination of the outcomes of the territorialization project by way of a closer look at the social relations governing the use of forestry land and rice terraces. ${ }^{5}$

\section{Forestry land}

In 1994 the state undertook a massive effort to classify large upland areas as forestry land and put the land under protected status. As described above, local cadres demarcated large parts of the slopes surrounding Chieng Dong as forestry land and requested villagers to refrain from further using this for agriculture. The cadres returned to Chieng Dong in 1995 to try out a new approach to forest protection. A renewed focus on forest protection was again motivated and supported by instructions and resources sent from the central authorities. The district was selected as a pilot site for the implementation of a German-funded watershed protection project.

With support from the project, the district authorities developed a more sophisticated approach to the enforcement of territorial control. Following 'best practice' in international development, they first conducted the PRA to assess villagers' needs. The PRA provided the approval needed by the cadres to go about their business. They conducted an inventory of allocated fields, built three-dimensional land use models for three villages and met villagers to discuss future land use. Visible products of their work were detailed maps depicting current land use, future land use and household land holdings. The maps seemingly demonstrated the state's newly gained control over the uplands. 
The interventions supported by the watershed protection project did not stop there. The project staff advised the district cadres to parcel up the forestry land and sign individual protection contracts with villagers. The district cadres consequently carved up the uplands into forest land parcels of between 10 and 20 hectares. For each parcel of forestry land with forest, the cadres signed protection contracts with an individual household or a group of households. The contracts promised the villagers financial compensation for their protection activity and exclusive rights to dry fuelwood and minor forest products on the land. In return, they had to commit to protecting the land from any other kind of use. They were not even allowed to graze livestock on the protected land, and the village's livestock were confined to an area of bare land set aside as grazing land.

Villagers were highly reluctant to sign the contracts with the district's Forest Protection Unit. Very few households signed contracts - and most of them only under pressure from village officials and district cadres - because the division of the uplands by function contradicted the flexibility of local uses. In the previous years, the uplands had been under a continuously changing patchwork of overlapping uses. Land became agricultural fields for two or three years and then reverted back to forest. Livestock grazing was an integral part of land use, particularly in the agricultural off-season, when livestock roamed the uplands freely. Villagers could also collect timber, firewood and other forest products wherever they wanted. The contracts thus implied an end to the flexible and shared use of the uplands, which explained the villagers' reluctance. In addition, the Forest Protection Unit appeared determined to enforce forest protection, and fined around ninety households for working agricultural fields on forestry land. The Forest Protection Unit also requested the villages to institute forest protection codes and organize forest protection teams to enforce the codes.

Despite the massive effort at forest protection in 1994 and 1995, agricultural land areas continued to expand in the following years. The area under cultivation in 1997 exceeded that in 1993 by a quarter, because villagers continued to use forestry land for cultivation. In particular, the rule that the top third of hills be protected as forestry land was easy to circumvent by villagers gradually extending their fields up the slopes. The state was unable to arrest the expansion of upland cultivation. Similarly, villagers continued to graze their livestock and collect timber and other forest products on forestry land. The state's claim of territorial control over the uplands, documented in various maps, protection contracts and a land register, could not be enforced. The forest protection contracts had little practical effect.

The district authorities largely failed to react to this lack of control. They abstained from drastic actions in both 1996 and 1997. The district's Forest Protection Unit virtually stopped enforcing forest protection regulations after the provincial campaign and the watershed protection project initiative had ended. The Forest Protection Unit fined only two households in those years. It paid out the full amount of protection payments, though many parcels of forestry land showed very visible evidence of their use for cultivation or grazing. The protection contracts consequently became very popular. Most households without protection 
contracts sought to participate in the protection activities, teaming up with households already holding contracts. District and provincial authorities even changed some of their regulations to accommodate village interests. Already by 1994, the district authorities had expanded the permissible amount of agricultural land that could be allocated to households. The provincial People's Committee followed suit at the end of 1994, when it raised the ceiling to 2 hectares. In 1997, the director of the provincial Cadastral Department indicated that the provincial authorities would no longer enforce the land ceilings. Consequently, the state could not enforce its legal control over forestry land. The appearance of territorial control communicated in cadastral records, local government reports and maps did not hold up in practice because local cadres not only looked away from discrepancies between state regulations and village practice but also actively sought ways to accommodate local practices that conflicted with central guidelines.

\section{Rice terraces}

In the mid-1980s, villagers began to build new rice terraces on the slopes surrounding the villages. Wherever they found a reliable source of water, they gradually levelled the soil and constructed terraces. By the early 1990s, rice terrace construction had become popular. Production on the fertile terraces contributed an increasing share of the staple food rice, and it accounted for most of the highly valued sticky rice. Villagers therefore built new terraces in increasingly remote locations, which eventually brought them into conflict with the residents of a small H'mong settlement. (The following account relies solely on interviews with Black Thai villagers and cadres, as the district authorities refused permission to interview H'mong.)

The H'mong had begun to cultivate upland fields and graze their livestock on the slopes of Huoi Sieu in the mid-1980s, and constructed more-permanent houses a few years later. In 1992, the commune's People's Committee formally recognized the H'mong settlement as a new village in Chieng Dong. Recognition included the decision to assign the land in Huoi Sieu to the H'mong settlement, which was also called Huoi Sieu. The land included $\mathrm{Na} \mathrm{Pa}$, where Thai households worked rice swiddens and a growing area of rice terraces. Although $\mathrm{Na} \mathrm{Pa}$ was around two hours walking distance from the Thai villages, its land was highly prized by the Thai, who had previously come to appreciate the land from when the cooperatives cultivated large rice swiddens on the fertile land. That land had drawn individual Thai households back to $\mathrm{Na} \mathrm{Pa}$ in the 1980s; by 1992 there were between twenty and thirty Thai households working rice swiddens in $\mathrm{Na} \mathrm{Pa}$, a few of them having started rice terrace construction.

Tensions rose quickly between the Black Thai and H'mong. The H'mong asserted their legal rights to the land assigned to them by the commune authorities. They recognized Thai claims on rice terraces but requested the Thai to give up cultivating upland fields. To lend force to their claims, they regularly let their buffalo and cattle roam into Thai upland fields. The Thai reacted with fences to protect their fields against the H'mong animals. They did not want to give up 
upland cultivation because the land in $\mathrm{Na} \mathrm{Pa}$ was fertile and because working rice terraces and upland fields at one location helped them save labour.

Land allocation in 1994 did not resolve the conflict. The allocation task force confirmed the village boundaries drawn by the commune two years before. At the same time, the cadres encouraged the Thai to retain control over their $\mathrm{Na} \mathrm{Pa}$ rice terraces. Some Thai households even took advantage of formal allocation to request the allocation of upland fields in $\mathrm{Na} \mathrm{Pa}$. By intent or neglect, the land titles issued to them by the district's cadastral office included the fields in $\mathrm{Na} \mathrm{Pa}$. At the same time, land allocation was not implemented in Huoi Sieu, although it was part of Chieng Dong. The H'mong received no land titles to bolster their claims on land. Land allocation even aggravated the conflict between H'mong and Thai. The new focus on territorial control convinced the Thai that they needed to gain formal rights to the land in $\mathrm{Na} \mathrm{Pa}$. Though the H'mong recognized their rights to the terraces, the Thai increasingly felt that $\mathrm{Na} \mathrm{Pa}$ needed to be detached from the H'mong village and integrated into a Thai village as a way to strengthen the security of their rights to the land. After all, the district's allocation guidelines did not allow allocation of village land to non-villagers.

The commune's administration eventually acceded to the Black Thai demands in 1995. Commune leaders decided to reassign the land in $\mathrm{Na} \mathrm{Pa}$ from Huoi Sieu to the neighbouring Thai village. The leaders, all Black Thai, justified their decision with reference to Black Thai investment in rice terraces. The terraces were also perceived as a more productive use of land than the upland fields cultivated by the H'mong. The commune authorities therefore privileged wet-rice cultivation, a land use preference that favoured Black Thai over H'mong land claims.

The conflict between Thai and H'mong in $\mathrm{Na}$ Pa continued despite the commune leaders' decision. Thai households kept working upland fields on land allocated to Huoi Sieu village. H'mong livestock continued to damage Thai crops. Some Thai even felt personally threatened by H'mong. In the face of such tensions, several Thai households decided to give up their land in $\mathrm{Na} \mathrm{Pa}$, selling their terraces to H'mong households from Huoi Sieu. The H'mong proved to be much more interested in wet-rice cultivation than the Thai had presumed, yet they had to resort to the threat of violence and to buy the land to gain control over land that had originally been assigned to them. Land allocation did not serve their claims, to say the least. Close relations with the local state authorities had instead allowed Black Thai villagers to take advantage of the state project to advance their own interests.

\section{Conclusion}

Internal territorialization became a key strategy employed by the Vietnamese state to control rural people and resources, and land allocation was the primary means of strengthening state control over rural people and areas. The General Department of Land Administration was put in place specifically to enforce this control. Yet territorialization remains an unstable project, and land allocation has been the object of sometimes intense negotiations within the state. The guidelines issued by the Ministry of Forestry, the provincial authorities and the district People's 
Committees have changed not only the procedures in place to implement land allocation but also the objectives it was supposed to serve. Land allocation was a significantly different project by the time it reached Chieng Dong.

Territorialization remains unstable because the cadastral grid is too rigid for the fluid nature of people's lived spatial relations. Land allocation promotes a notion of 'abstract space' (Vandergeest and Peluso 1995: 388) that is different from people's experienced spatial relations. Abstract space can be divided into discrete units that are clearly bounded and uniform within, but local land relations are fluid and overlapping (Sikor 2004b). Fields expand up slopes and move between locations in reaction to available labour, food requirements, market opportunities and regenerative ecological dynamics. Grazing rights change seasonally with the cultivation cycle, blending in with other uses of the uplands. This fluid patchwork of overlapping uses does not fit the notion of abstract space underlying land allocation. In reaction, therefore, Black Thai villagers ignored the demarcation of forestry land undertaken by the district authorities.

While fending off state control over the uplands, the Black Thai however used the state project to advance their own interests against the neighbouring H'mong village by taking advantage of land allocation to lodge claims on land to which they were not entitled in the land allocation guidelines. More importantly, they have understood the new focus on control over land as an opportunity to strengthen their claims on a fertile upland area. Adopting the territorial rationale underlying allocation, they eventually achieved their goals with active support from the district authorities.

State power cannot be taken for granted, but it is produced in the state's concrete operations. These operations may be quite different from the formal procedures instituted by the central state in order to direct them. Similarly, their outcomes may be very different from those communicated in official reports and maps. In this case, the Vietnamese state's project has possessed the potential to reduce livelihood opportunities in the northwestern mountains and take authority over land use decisions away from the Black Thai villagers. The guidelines issued by the Ministry of Forestry and the provincial People's Committee implied a massive reduction in land available for agriculture and the centralization of decisions over land use for the sake of national interests in watershed protection. Similarly, the reports and maps prepared in the course of land allocation portray an all-powerful state that implements central and provincial directives. In practice, however, the presumably marginalized villagers have fended off demands by the state, even utilizing the state project to advance their own interests. Practical state control over land is surprisingly weak, in a state that is often described as powerful (Porter 1993).

Suggestions of limited state capacity, or alternatively a strong civil society, fall short of capturing the complex political dynamics. The discrepancy between local practice and central directives emphasizes the concrete political conditions that facilitate local influence on state projects, particularly the relations between different social groups and between these groups and the state. State projects offer opportunities for reshuffling the distribution of resources and authority among social groups. Social groups therefore compete for access to the benefits of state 
projects, a competition that is influenced by the broader relations between these groups and their relations with the state. In this case, the Black Thai had better cards to play. The Black Thai assumed most leadership positions and staffed the People's Committee at the district and commune levels. Black Thai villagers could rely on their ethnic compatriots in the local state to ignore practices that differed from legal regulations and support their land claims against those lodged by H'mong. They also knew that the historical authority relations over land and autonomy within the Vietnamese state afforded the villages and local authorities significant leverage in the interpretation of central directives (Sikor 2004b). ${ }^{6}$

The discrepancy between local practice and central directives also highlights the need to perceive the state as an arena of struggles over resources and authority and to identify significant cleavages that may divide agencies at any one level of the state. Here, cleavages between different levels of the state became more important, putting local authorities in opposition to the central state. Whether divisions between local and central authorities are significant will depend on the local political context and the organization of political and administrative control within the state (Sikor 2004a). Political context and state organization shape the concrete location of divisions with respect to the different levels of the state.

Local cadres play a key role in the exercise of state power (Sikor 2004a). These local agents of the state interpret the instructions sent by central authorities, modifying them in response to their own interests and understandings of the problem. Being located at the intersection of state and villages, they also react to demands by local people. Their reactions tend to favour one social group over another, or one actor over another, and they are certainly not passive recipients of instructions handed down by the central state. Instead, they actively take advantage of state projects to reassert their control over authority and resources and renegotiate their location at the intersection of state and villages.

Such an ethnography of the state includes attention to the concrete forms chosen to accomplish state rule in practice. The central government uses different forms to gain control over people and places. These forms influence the state's concrete actions as well as local people's reactions to them. Local people respond to concrete state projects, both in their resistance to them and in their attempts to utilize them for their own objectives. They may even adopt the rationale and terms of state projects as a way to gain leverage on state authority and resources. The forms chosen to accomplish state rule also define the spaces available to central and local state agents for interpreting and modifying central directives. In this way, they influence the nature and location of cleavages within the state as well as the terms used in contestations over resources and authority within the state.

Such conclusions suggest the need to take a fresh look at the notion of marginality in 'regional political ecology'. Location at the margin may afford a flexibility that social groups do not have at the centre. People may live in ecologically marginal locations, where agriculture does not yield the returns generated under more favourable conditions. They may be marginalized in a political-economic sense, being deprived of significant participation in the state and markets. Yet this very marginality may afford people spaces in the negotiation of state projects that do not 
exist at the centre. Ecologically marginal regions may contain biophysical resources of little interest to powerful interests. Political-economic marginality may create special possibilities for people to retain leverage over resources and authority, and exercise established power relations. Marginal people may become highly skilled in utilizing and expanding these quasi-autonomous spaces. The outcomes of their struggles depend on local political contexts, the organization of political and administrative control within the state and the concrete forms chosen to accomplish state rule in practice. Marginal places may contain microcosms of local political relations, affording seemingly marginal people more leverage on resources and authority than might be expected.

\section{Notes}

1 I would like to express my sincere gratitude to Janet Sturgeon and Peter Vandergeest for stimulating and constructive comments on an earlier version of this chapter. The fieldwork reported in this chapter was conducted under a grant by the Ford Foundation.

2 Tai is a generic ethnolinguistic term that covers a range of groups in Vietnam, Laos, southwestern China and Burma.

3 The problems faced by collective production and state procurement in Chieng Dong reflected a more general trend in the province, as suggested by numerous articles published in the provincial newspaper in the 1980s.

4 I owe these insights to Dao Minh Truong, who interpreted aerial photographs from 1952 and CORONA satellite images from 1968 for Chieng Dong.

5 See Sikor (2004a, 2004b) for discussions of the outcomes of land allocation with respect to wet-rice and upland fields as well as land statistics. The findings discussed in these papers match the results presented in this chapter. I chose to focus on the conflicts around forestry land and rice terraces in this chapter because they best illustrate my argument about marginality and state power.

6 See Sowerwine (2004) for similar investigations in two other contexts of northern Vietnam. The comparison of her findings with mine attests to the significance of local political context as a factor shaping the outcomes of state projects.

\section{References}

Ban Chap Hanh Dang Bo Dang Cong San Viet Nam Tinh Son La (Executive Committee of the Son La Cell, Communist Party of Vietnam) (1994) Lich Su Dang Bo Tinh Son La, Tap II 1954-1975 (History of the Son La Party Cell), Volume II 1954-1975, Hanoi: Nha Xuat Ban Chinh Tri Quoc Gia.

Blaikie, P and Brookfield, H (1987) Land Degradation and Society, London: Routledge.

Cam Trong (1978) Nguoi Thai o Tay Bac Viet Nam (The Thai in the North-west of Vietnam), Hanoi: Nha Xuat Ban Khoa Hoc Xa Hoi.

- and Huu Ung (1973) Che Do Ruong Cong Va Hinh Thai Xa Hoi Cua Nguoi Thai Tay-Bac Truoc Day (Historical Communal Land Relations and Social Structure of the Thai People in the North-west), Nghien Cuu Lich Su (Historical Research), 155, 50-57.

Chu Van Tan (1962) Mot Bien Doi Cach Mang To Lon o Mien Nui (A Big Revolutionary Change in the Mountains), Hanoi: Truth Publishing House.

Dang Nghiem Van, Cam Trong, Kha Van Tien and Tong Kim An (1977) Tu Lieu Ve Lich Su Va Xa Hoi Dan Toc Thai (Materials about the History and Society of the Thai Ethnic Group), Hanoi: Nha Xuat Ban Khoa Hoc Xa Hoi. 
Fforde, A and deVylder, S (1996) From Plan to Market: Transition in Vietnam 1979-1994, Boulder, CO: Westview Press.

Lebar, F, Hickey, G and Musgrave, J (1964) Ethnic Groups of Mainland Southeast Asia, New Haven, CT: Human Relations Area Files Press.

McAlister, J (1967) Mountain Minorities and the Viet Minh: A Key to the Indochina War, in P Kunstadter (ed.), Southeast Asian Tribes, Minorities, and Nations, Princeton, NJ: Princeton University Press, pp. 771-844.

Porter, G (1993) Vietnam: The Politics of Bureaucratic Socialism, Ithaca, NY: Cornell University Press.

Sack, R (1986) Human Territoriality: Its Theory and History, Cambridge: Cambridge University Press.

Sevenier, P (1905) Commissariat du Gouvernement de Van-Bu, Revue Indo-Chinoise, 3(2), $149-55$.

Sikor, T (2004a) Local government in the exercise of state power: the politics of land allocation in Black Thai villages, in B Kerkvliet and D Marr (eds), Beyond Hanoi: Local Government and Authority in Vietnam, Singapore: Institute of Southeast Asian Studies, pp. 167-96.

- (2004b) Conflicting Concepts: Contested Land Relations in Northwestern Vietnam, Conservation and Society, 2(1), 59-79.

Silvestre, J (1918) Les Thai Blancs de Phong-Tho, Bulletin de L'Ecole Française d'Extrême-Orient, 18(4).

Sowerwine, J (2004) Territorialization and the Politics of Highland Landscapes in Vietnam: Negotiating Property Relations in Policy, Meaning, and Practice, Conservation and Society, 2, 80-105.

Steinberg, D (1987) In Search of Southeast Asia, Honolulu, HI: University of Hawaii Press.

Thongchai Winichakul (1994) Siam Mapped: A History of the Geo-Body of a Nation, Honolulu, HI: University of Hawaii Press.

Tran Phuong (1968) Cach Mang Ruong Dat o Viet-Nam (Land Revolution in Vietnam), Hanoi: Nha Xuat Ban Khoa Hoc Xa Hoi.

Tran Thi Que (1998) Vietnam's Agriculture: The Challenges and Achievements, Singapore: Institute of Southeast Asian Studies.

Vandergeest, P and Peluso, N (1995) Territorialization and State Power in Thailand, Theory and Society, 24, 385-426.

Vien Dan Toc Hoc (Institute of Ethnology) (1978) Cac Dan Toc It Nguoi o Viet Nam - Cac Tinh Phia Bac (Ethnic Minorities in Vietnam - the Northern Provinces), Hanoi: Nha Xuat Ban Khoa Hoc Xa Hoi.

World Bank (1993) Energy Sector and Investment Priorities Review, Washington DC: The World Bank.

Wyatt, D (1984) Thailand: A Short History, New Haven, CT: Yale University Press. 


\title{
7 Seeds of discontent \\ Oil palm and the changing production strategies among smallholders in Papua New Guinea
}

\author{
George N. Curry and Gina Koczberski
}

Boserup's agricultural intensification model of the late 1960s (Boserup 1965), on which much debate over agronomic change still rests, postulated that rising population pressure over a fixed land area results in progressive agricultural intensification and the adoption of new technologies as people attempt to raise agricultural production. The model maps a unilinear sequence of agricultural change, as people move from less to more intensive agricultural practices to achieve higher production, with population pressure the key stimulus driving agricultural change. In this process, labour use increases and efficiency falls as labour is substituted for land.

Boserup's model provides a framework for understanding relationships between population density and the transformation of agricultural systems, and has stimulated much research and debate on agricultural intensification in developing countries (see Netting 1993; Turner et al. 1977, 1993; Tiffen et al. 1994). As a general theory of agricultural change, the model is useful for explaining the variability and changing characteristics of agricultural systems in several nonindustrial agrarian societies, but it is less able to account for the diverse site-specific variables that influence processes of agricultural change. Hence the model's 'value is not in being the final word but in being the first word; it is a model made to go beyond' (Stone 2001: 164). Indeed, there is now a large volume of 'beyond Boserup' literature that highlights the inability of the model to capture the complexity of processes of agricultural change. Other significant and often overlapping socio-economic, political, institutional and environmental variables also stimulate or facilitate agricultural change (Brookfield 1972, 1984; Netting et al. 1989; Tiffen et al. 1994; Morrison 1996; Guyer 1997; Stone 1998). The model has also been criticised for its emphasis on agricultural intensification as the only possible reaction to population pressure, so broadening the intensification debate by highlighting other responses, such as migration, changes in land tenure, agricultural and non-farm income diversification, environmental conservation and investment (Mortimore 1967; Bilsborrow 1987; Adams and Mortimore 1997; Brookfield 2001a, 2001b).

Recently, Brookfield (2001a, 2001b) argued that a more comprehensive understanding of agricultural change requires acknowledging farmers' capital assets, 
management skills (in particular the organisation of land and labour) and innovations, and their adaptability and flexibility in responding to changing conditions through the diversification of production and livelihoods. This more holistic approach to agricultural change also acknowledges that for contemporary agricultural societies 'the reality is one of constant adaptation to changing biophysical, social, demographic, economic and political conditions' (2001b: 182). Change is not merely in one direction and nor is it unidimensional. Rather, the labour intensification of agricultural production systems is only one of several possibilities, and labour is but one dimension. Brookfield concluded by stressing that in constantly changing environments, the diversification of production and livelihoods and the ability to adopt better strategies of managing and exploiting different resources are the keys to survival and successful change (2001b: 189).

In the context of the more recent debate on agricultural intensification, this chapter explores how smallholders residing on the Hoskins and Bialla oil palm land settlement schemes in West New Britain, Papua New Guinea (PNG) (Figure 7.1) maintain agricultural production, economic security and social stability in the context of population growth, limited opportunity for land use change, fluctuating commodity prices and contemporary social change. ${ }^{1}$ The chapter has two main objectives. The first is to broaden the intensification debate by illustrating the complex role of socio-cultural factors in agrarian change. While recognising that population pressure is an important variable explaining change in oil palm production strategies and other livelihood pursuits, the specific forms of managing and organising labour and production can only be understood by examining processes

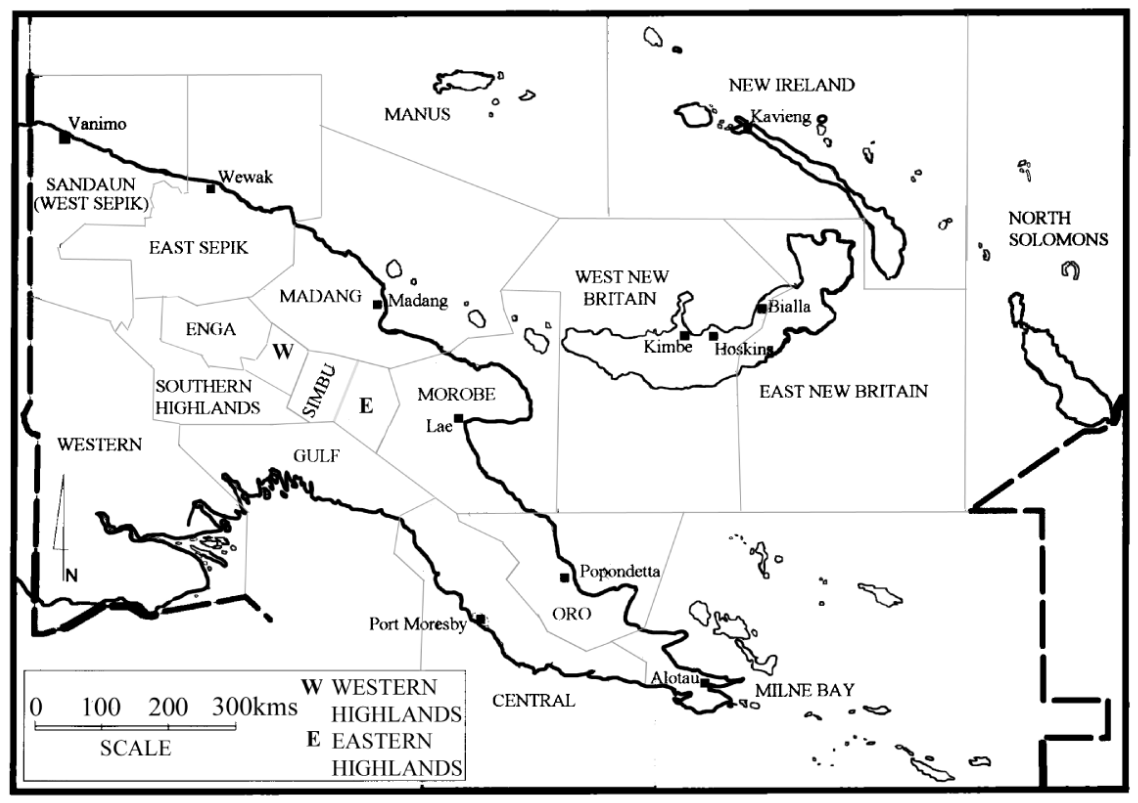

Figure 7.1 Papua New Guinea. 
operating within the household (i.e. household decision-making) and how these processes interact with the broader socio-cultural, economic and institutional environments in which they are embedded. Household leadership, social relations of production, income distribution, social and kinship relations and obligations, and rising material aspirations are all important here. At the same time, household decision-making and farming practices are contained within an externally imposed land settlement model and a relatively rigid commercial and institutional environment.

The second objective is to explore further Brookfield's concept of risk in relation to agricultural innovation, which he raised initially in his 1984 article 'Intensification Revisited' and again more recently in his 2001 book Exploring Agrodiversity. While intensification, on the one hand, is about increasing inputs (e.g. labour or fertiliser), raising productivity innovation, on the other hand, involves new ways of combining the factors of production to 'create qualitatively new elements in the farming system' (Brookfield 2001a: 181). This can entail new ways of organising land and labour or adopting new technologies in an attempt to create more viable agricultural production systems. The result is an increase in the productivity of labour inputs. Brookfield (2001a: 16) points out that the intensification of labour inputs may be a consequence of innovation, but it is a separate phenomenon to the productivity or qualitative changes in labour input under innovation.

According to Brookfield (1984: 38), the primary purpose of most innovations is to reduce elements of risk and uncertainty in agricultural systems (e.g. climatic and other natural hazards, environmental deterioration, etc.). Whilst there is some recognition of the social risk of innovation, the concept is not well developed. In this chapter the concept of agricultural risk is extended to social risk: the social disharmony and conflict that can occur within family and kin groups, particularly those under population stress, that may eventually result in the social fragmentation and dislocation of the productive group. To reduce these social risks, households and individuals embroiled in conflict will negotiate and develop innovative production strategies involving new combinations of land and labour. Innovative agricultural strategies may therefore not be concerned primarily with increasing production or labour productivity, but may actually be driven by efforts to ease social tensions and regain some measure of kin group cohesiveness in situations of social conflict. Indeed, measures taken by smallholders to resolve social conflict through agricultural innovation may, at times, take precedence over raising agricultural production and incomes (see the section Social conflict, below). This implies that smallholders evaluate innovations in labour strategies not solely in terms of production and income but also by other meaningful criteria, such as the status of social relationships within the group.

\section{Oil palm land settlement schemes in Papua New Guinea}

Like many other countries in the 1950s and 1960s, PNG established land settlement schemes (LSSs) on alienated customary land as a means of promoting agricultural and economic development. The Australian colonial administration viewed these 
schemes as part of an overall strategy to develop a national agricultural export industry. The schemes were also viewed by the administration as a way to improve rural incomes, integrate Papua New Guineans into the cash economy, relieve population pressure in some rural areas and bring into production 'unused' or 'under-exploited' land (Hulme 1984: 81).

PNG's first oil palm LSS was established in 1968 at Hoskins, on the north coast of West New Britain (Figure 7.1). The Australian administration considered the coastal strip of northern New Britain ideal for timber extraction, agricultural production and LSSs because of its sparse population, suitable climate, fertile soils and extensive forest resources. The operation and structure of the scheme were based on the nucleus estate model, with smallholder land settlement subdivisions surrounding privately owned estate plantations and a centrally located company mill. The estate company provided smallholders with access to planting material, extension services and fruit transport and processing (Hulme 1984). Following the perceived early success of the Hoskins LSS, the model was adopted for the nearby Bialla scheme, which commenced operations in the mid 1970s. In both schemes, customary land was converted to state leasehold land, and individual lease holdings of approximately 6-6.5 hectares were allocated to smallholder families on 99-year leases. At the time, 6 hectares were deemed adequate for a family's needs, and smallholders were required to plant 4 hectares of oil palm with the remaining 2 hectares reserved for food gardens.

In recruiting smallholders for the LSSs, priority was given to applicants from land-short areas, such as parts of the West Sepik and Morobe provinces, the Wabag and Maprik areas and the Gazelle peninsula of East New Britain. Special government publicity committees were set up in some of these land-short areas to encourage people to resettle on the schemes. At Hoskins, the majority of settlers were recruited from East and West Sepik (42 per cent), followed by Chimbu (22 per cent), East New Britain (15 per cent), Morobe (11 per cent) and West New Britain (4 per cent) (Hulme 1984: 242). Large numbers of people from these land-short areas have since settled in West New Britain, and leaseholders now provide a very important base for visitors from poor migrant source areas (Curry and Koczberski 1998, 1999).

Following the establishment of the LSSs at Hoskins and Bialla, local landowners were also encouraged to plant oil palm under the village oil palm scheme (VOP), and their participation in the industry has been increasing over the years. Most VOP blocks are 2 hectares in size, and the majority of VOP smallholders also have holdings of other cash crops and remain engaged in subsistence production. In 2002, Hoskins and Bialla smallholders contributed 34 per cent and 54 per cent respectively to total company production.

\section{The demographic context}

The demographic characteristics of the Hoskins and Bialla schemes have changed greatly since their establishment. The single nuclear family that typically first settled the blocks has gradually been replaced with multiple family units co-residing 


\section{George N. Curry and Gina Koczberski}

on blocks, as second generation settlers marry and continue living with their parents. Population density per block has risen markedly since the early 1970 s (Table 7.1). At the more recent Bialla scheme, the mean number of persons per LSS block was 11.1 in 2002.

The rapid rate of population growth at Hoskins LSS between 1990 and 2000 is partly attributable to the difficulties settlers experienced when attempting to resettle in their 'home' villages and the contraction of off-block residence options. Opportunities for re-establishing themselves at 'home' are becoming remote because of their long absences, together with the fact that many of their children were raised in West New Britain and spoke Melanesian Pidgin rather than their indigenous languages (see Curry and Koczberski 1999; Koczberski et al. 2001b). Their home areas are also likely to be experiencing population pressure, given that settlers were initially recruited from land-short areas, in some of which rising population pressure is leading to a tightening of rules governing resource access (e.g. Carrier and Carrier 1989; Curry 1997; Neumann 1997; Zimmer-Tamakoshi 1997). This makes it much more difficult for long-term absentees to re-establish themselves in their home villages. Moreover, the opposition to informal urban settlements by provincial governments (Koczberski et al. 2001a) and the high rate of unemployment in PNG mean that settlers' off-block residence options are now much more constrained than in earlier decades.

It is not uncommon for three generations and several household units to be sharing the resources of one 6-hectare block. On these multiple household blocks, the original settler house of milled timber typically sits among a cluster of several other houses, usually constructed of bush materials, and the 2-hectare reserve of food gardening land is shared among co-resident households. The monthly oil palm income the leaseholder receives from the milling company for oil palm fruit must also be spread across several households of varying age, status and household needs. For example, Beno and Lina, elderly Sepik leaseholders, still reside in their original house, but their house is now surrounded by five 'bush' houses. Together, the six houses accommodate 26 family members, and the monthly oil palm income is distributed among seven households.

Blocks with multiple, co-resident households are complex economic and social units. Because each co-resident household must meet costs for healthcare, schooling, food and other basic necessities, these blocks often experience economic and social pressures that can lead to tensions and conflicts between residents. Disputes and violence often occur around payday, triggered by the distribution of oil palm income. Although grievances are frequently resolved amicably, occasional violence does erupt, especially between fathers and sons and between brothers. In some

Table 7.1 Mean number of persons per LSS block, Hoskins, 1972-2000

\begin{tabular}{lllll}
\hline Year & 1972 & 1975 & 1990 & 2000 \\
\hline Mean numbers of persons per block & 5.9 & 7.2 & 8.6 & 13.3 \\
\hline $\begin{array}{l}\text { Note } \\
\text { No long-term population data are available for the Bialla LSS. }\end{array}$ & &
\end{tabular}


cases, violent disputes can lead to the eviction of a block resident and their family, or to a household being placed under intense pressure to leave the block.

In response to this new socio-demographic environment, and to secure their livelihoods, smallholder households are adopting new oil palm management and harvesting strategies, and are pursuing a range of alternative livelihood strategies involving both agricultural and non-agricultural activities (Koczberski and Curry 2003). The LSSs provide a useful case study of socio-agronomic change because the area of land per block is fixed (6-6.5 hectares), the terms of the lease agreement preclude removal or intercropping of oil palm, and the 2 hectares of reserve garden land is the only land over which smallholders have some discretionary use. These changes in oil palm production can now be examined in the context of a new sociodemographic environment and a rigid institutional framework.

\section{Smallholder oil palm production and innovation}

The Hoskins and Bialla oil palm schemes follow a fortnightly harvesting schedule, in which the fruit is harvested by smallholders and then stacked in nets on the edge of their blocks for collection by company or contractor trucks (Figure 7.2). The nets of fruit are weighed at the roadside collection point and the weight recorded on a docket. Smallholders receive a monthly payment for their oil palm fruit.

Harvesting is physically demanding work and requires the use of a chisel when the palms are young (palms bear at 18 months), switching to scythes mounted on

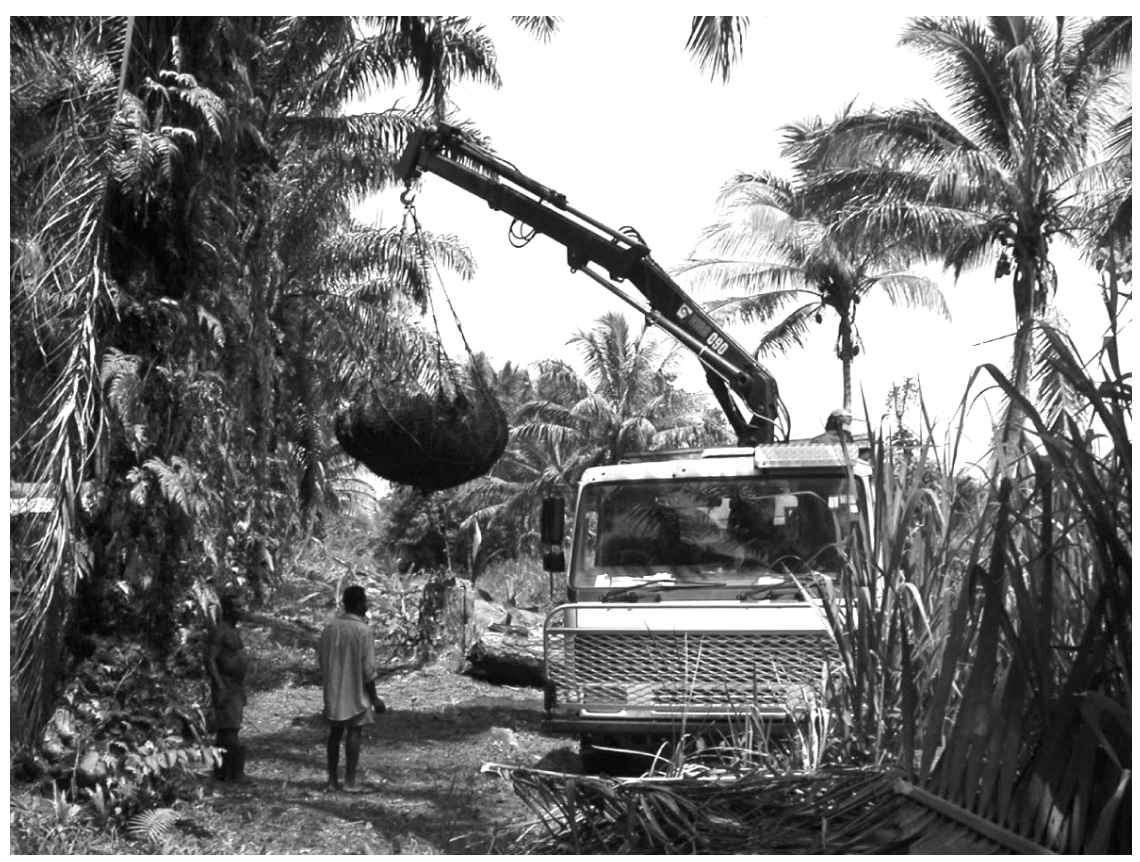

Figure 7.2 Company oil palm harvest pickup, West New Britain. 


\section{George N. Curry and Gina Koczberski}

harvesting poles when fruit bunches are above head height. Harvesting takes between two and three days each fortnight, depending on the age of the palms, area planted to oil palm and available labour. Both the fruit bunches (fresh fruit bunches) and fruitlets (loose fruit dislodged from the main bunch during harvesting) are collected. There is generally a clear division of labour by gender and age. Typically, loose fruit is collected by females of all ages, using wheelbarrows or large 10 kilogram plastic rice bags to cart the fruit to the roadside collection point (Figure 7.3). Fruit bunches are harvested by males, with elderly men relying on their younger sons or other male kin to harvest very tall palms (Figure 7.4). Males cart the fruit bunches to the roadside in wheelbarrows, though women occasionally undertake this task. Women sometimes harvest small bunches from young palms, and weigh these with their loose fruit. The companies pay women separately for loose fruit.

\section{Changing organisation and remuneration of labour}

Oil palm production requires skills in organising and managing household labour because harvesting is labour intensive and must be completed within three days of a scheduled fruit pickup by the mill truck. If fruit is not processed within three days, oil quality is lower (a problem for the milling company) and bunch weight declines (less income for growers). To maintain yields, smallholder households must work outside the harvesting period, applying fertiliser, pruning and stacking oil palm

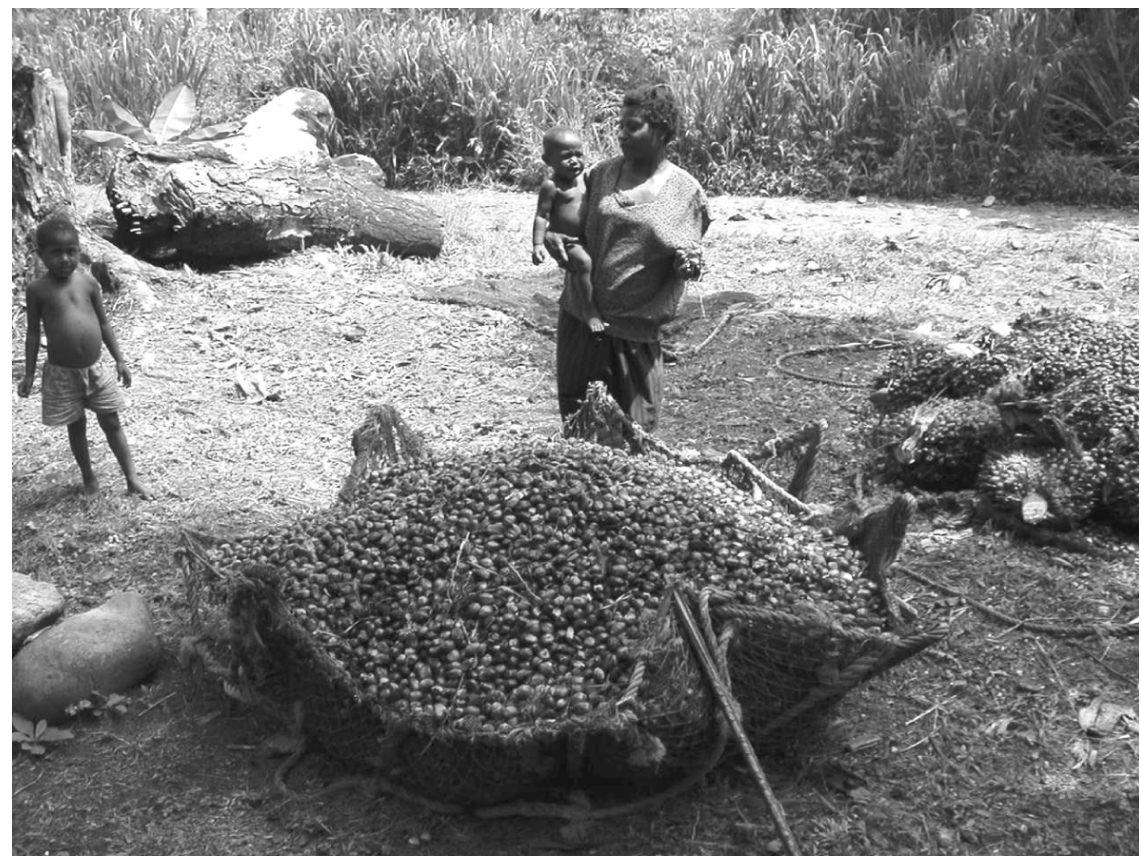

Figure 7.3 Woman's oil palm 'lus frut' harvest, West New Britain. 


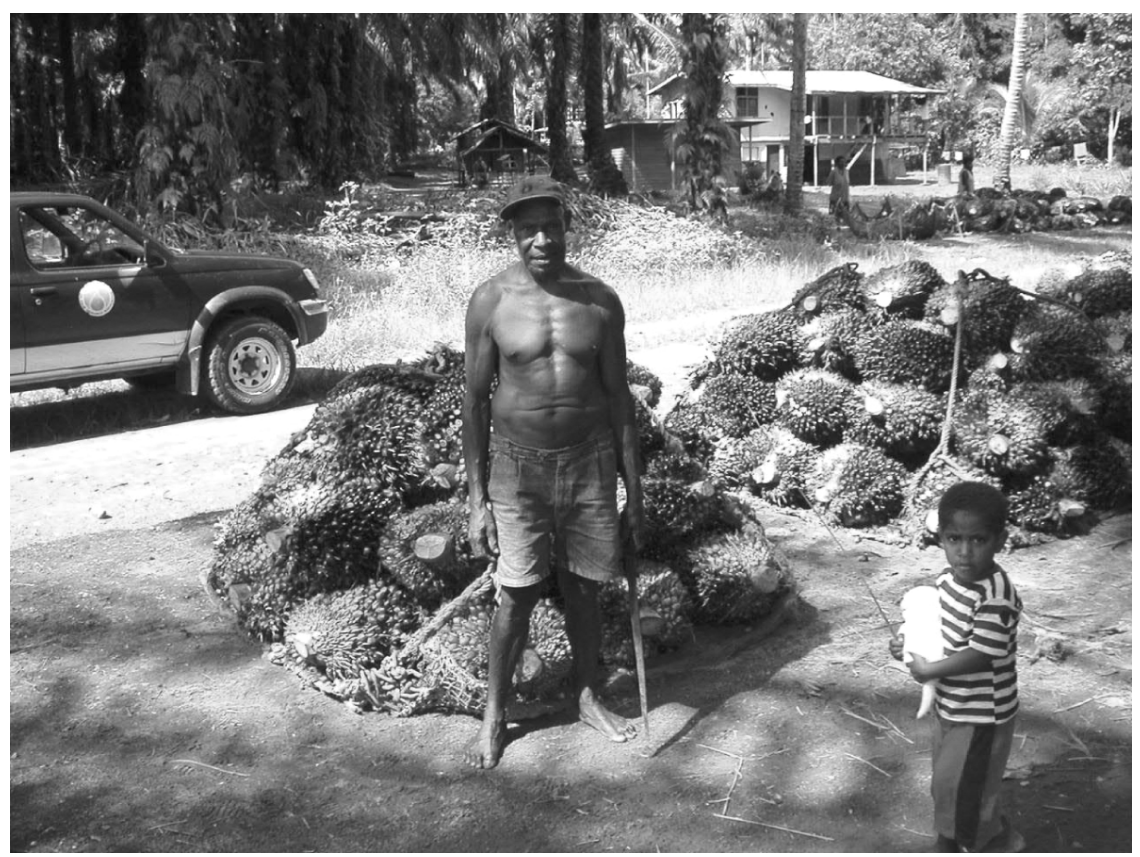

Figure 7.4 Fresh oil palm fruit bunch harvest, West New Britain.

fronds in windrows, weeding or spraying herbicide, and mending harvesting tools and wheelbarrows.

Until the mid 1980s, block maintenance and harvesting were undertaken by a communal work group involving all or most adult family members from coresident households. Smallholders call this harvesting strategy wok bung ('working together'). The male head of the block, typically the father and original leaseholder, mobilised labour and allocated specific harvesting tasks. Provided there was sufficient labour on the block, the high level of interhousehold cooperation during harvesting under this wok bung strategy resulted in an adequate labour supply for complete and regular harvesting. The income generated from harvesting was distributed among block residents by the head of the block. The main feature of the wok bung strategy was its highly centralised control of production, with the head of the block responsible for organising labour and distributing income. However, as the number of co-resident households has increased, many multiple household blocks have recently adopted new oil palm production practices that involve different ways of organising and remunerating labour.

A new harvesting strategy that has emerged and is becoming more widespread involves a move away from communal, wok bung production involving all adults from co-resident households to a strategy where harvesting work and the corresponding income generated are rotated on a monthly schedule among individual co-resident households. This new production strategy is known locally as markim 
mun (literally 'marking the month'), and coincides with the milling company's monthly payments to smallholders. At Hoskins, where it emerged initially, 50 per cent of LSS blocks identified markim mun as their main production strategy in 2002. Following its initial appearance at Hoskins, the markim mun strategy has since spread to the nearby Bialla scheme (Table 7.2).

Two fundamental differences between the old wok bung and new markim mun harvesting strategies concern the organisation and remuneration of labour. Under markim mun a different household each month harvests the oil palm and retains the corresponding income. Labour is drawn predominantly from the household whose month it is to harvest, with occasional recruitment of additional labour from coresident or off-block households. By contrast, under wok bung labour is drawn from all co-resident households, with labour organisation and the distribution of oil palm income centrally controlled by the head of the block. Hence, under markim mun, there is less interhousehold cooperation in harvesting, and the size of the work group is typically smaller than that of the co-operative wok bung strategy. While the head of the block (usually the father) may still ensure that harvest months are rotated fairly among co-resident households, his control over the organisation, management and remuneration of labour is diminished as such decisions become the responsibility of the head of the household allocated that month's production (usually a married son).

The two harvesting strategies are not rigid and some blocks switch between them, depending on their socio-economic circumstances at particular times. Some multiple household blocks have adopted a 'mixed' strategy, where the adult members of every household harvest together (wok bung) but rotate the oil palm income each month amongst co-resident households. This is similar to the Sande (Sunday) system that has long operated among plantation workers. Every payday the wages of voluntary group members are allocated to one member of the group. Each member of the group receives a large sum of money when it is his turn to receive the wages of other group members. This system enables workers to make large purchases, such as to travel home, and to make major contributions to indigenous exchange, such as brideprices. In the case of LSS blocks, the leaseholder may be relinquishing some but not all of his authority in managing the block. This may be a partial response to the presence of conflict on the block, or, in some instances, it may represent a transitional stage as a block experiments with different labour strategies to lessen conflict.

Table 7.2 Percentages of LSS blocks employing different harvesting strategies at Hoskins, Bialla and Popondetta

\begin{tabular}{llll}
\hline LSS & $\begin{array}{l}\text { Wok bung } \\
(\%)\end{array}$ & $\begin{array}{l}\text { Markim mun } \\
(\%)\end{array}$ & $\begin{array}{l}\text { 'Other' mixed/hired labour } \\
(\%)\end{array}$ \\
\hline Hoskins & 48 & 50 & 2 \\
Bialla & 67 & 32 & 1 \\
Popondetta & 93 & 0 & 7 \\
\hline
\end{tabular}


Levels and types of labour remuneration differ in important respects between the two production strategies. Under a communal wok bung strategy, decisions relating to labour remuneration rest largely with the head of the block, with payment levels governed by consideration of age, gender and kinship status. The social and kinship status of some members of the work group means that their remuneration level is often less than the market value of their labour contribution and often well below that of work group members of higher status. Women and younger sons normally have a lesser claim on the income than men and older sons, and as a consequence labour remuneration can vary greatly within and between households on wok bung blocks.

\section{Labour practices and indigenous exchange}

In-kind payment of labour (usually with food) is more commonly associated with wok bung harvesting than with markim mun harvesting. Because remuneration under a wok bung strategy is mediated by indigenous cultural norms and values, the head of the block is able to draw on 'unpaid' or 'underpaid' household or kinship labour using the rhetoric of obligations to the collective group. This moral economy of labour means that such labour contributions lie outside the market and are cast as indigenous exchange not requiring market rates of remuneration. However, other exchange obligations are created by such gift transactions: the son giving labour will expect his father to be the main financier of his brideprice; the son-in-law or nephew may anticipate that his family will be given rights to live on the block and be granted some land for gardening.

Indigenous or gift exchange in PNG is central to maintaining and building social relationships and defining group boundaries. Without exchange the identity and unity of the kinship group is undermined, and opportunities for resolving conflict decline. Participation in the cash economy through wage labour, small business or cash-crop production is often motivated by a desire to earn cash to invest in indigenous exchange (Curry 1999). Similarly, gifts of labour, whether in subsistence production, house building or the production of cash crops such as oil palm, have meaning beyond the market value of work done (Curry 2003). The wok bung cooperative labour strategy is most closely aligned with this indigenous exchange economy.

However, with the shift to the markim mun strategy, labour remuneration is governed less by cultural norms associated with the indigenous exchange economy and more by market values, so that remuneration of labour is more likely to reflect market rates of pay. There is also limited in-kind payment for labour, and if food is cooked for the work group it is usually in addition to, not in lieu of, cash payments for labour. Thus, under markim mun market relations are privileged over indigenous economic and social relations of production and exchange.

Overall, the shift from wok bung to markim mun is more than a simple reorganisation of labour in oil palm production. It also signals a significant socio-political reorganisation of power and economic relations on a block. The shift from the highly centralised organisation of production under wok bung means that leaseholders - the 
older men - no longer have absolute control over labour and income flows, indicating their diminished role in oil palm production. Further, the adoption of the markim mun strategy entails an erosion of indigenous economic and social relations in oil palm production with a consequent strengthening of market-based economic relations. Whether or not this represents a permanent shift towards market-based labour relations is a difficult question to answer, given that throughout PNG indigenous economic forms and cultural values have shown resilience and an ability to renew and refashion themselves by exploiting new opportunities in altered political and economic contexts (e.g. Boyd 1985; Maclean 1989; Nihill 1989; Goddard 1995; Imbun 2000; Curry 2003). However, the shift to more market-based economic relations associated with the markim mun strategy remains incomplete and ambiguous because elements of the two economic frameworks are present in both strategies. The change is more one of degree than a real transformation of economic and social relationships.

\section{Population pressure}

This section argues that innovations in labour organisation and remuneration arose endogenously in response to several interrelated factors, including population growth, changing generational values and aspirations, and social conflict. While the switch from wok bung to markim mun is associated with population density, it is driven largely by a younger generation of men holding different values and aspirations to their fathers. For this younger generation of men, social conflict is an instrument for change, the effectiveness of which increases with population density. Two kinds of evidence suggest that population density is associated with the shift from wok bung to markim mun, though the link appears to be indirect. First, anecdotal evidence from extension officers and smallholders indicates that the markim mun is a recent innovation that emerged at Hoskins within the past 10 to 15 years, coinciding with the period (since 1990) of most rapid population growth since the scheme's inception (Table 7.1). A major study of smallholder production in the Hoskins and Bialla schemes in 1991 made no reference to the markim mun strategy, and the project's agro-sociologist did not recall markim mun being a significant feature of harvesting practices during her surveys (Landell Mills 1991).

Second, blocks that have switched to markim mun tend to have a larger resident population and a greater number of co-resident households than blocks practising wok bung strategies (Tables 7.3 and 7.4). Moreover, at Popondetta in 2001, where mean population per LSS block at 8.3 is much lower than at Bialla or Hoskins, there was no markim mun strategy (Table 7.2), though agricultural extension officers stated that a few blocks had adopted this strategy.

The evidence suggests that the conventional wok bung harvesting strategy that dominated smallholder production until recently is becoming less viable in the context of population growth and rising economic pressure on multiple household blocks. Wok bung appears more suitable for smaller, disciplined work groups, but becomes more difficult to sustain as block population increases and co-resident households start behaving more like autonomous economic and social units. 
Table 7.3 Mean population per LSS block by harvesting strategy at Bialla and Hoskins

\begin{tabular}{lcl}
\hline LSS & Wokbung & Markim mun \\
\hline Bialla & 9.2 & 14.3 \\
Hoskins & 12.2 & 14.7 \\
\hline
\end{tabular}

Table 7.4 Mean numbers of households per LSS block by harvesting strategy at Bialla and Hoskins

\begin{tabular}{llll}
\hline LSS & Wokbung & Mixed strategy & Markim mun \\
\hline Bialla & 1.6 & 2 & 3 \\
Hoskins & 2.5 & 1 & 3.2 \\
\hline
\end{tabular}

However, as we argue below, the suggestion that population pressure causes social conflict directly, and thus leads to agricultural innovation, is inadequate for explaining agricultural change in the smallholder sector.

\section{Social conflict}

While smallholders did not deny that population pressure was a contributing factor in their decision to switch to a rotational, markim mun harvesting strategy, almost all interviewees stressed that the shift was triggered by social conflict (often between father and sons and between brothers) rather than by population pressure itself. Conflicts often arise on multiple household blocks and usually involve household heads (sons) contesting labour allocations and the distribution of oil palm income by the leaseholder (father or elder brother). Conflict may take several forms, including withdrawal of oil palm labour, 'stealing' the monthly oil palm cheque, verbal disagreements, physical violence and occasional evictions of block residents. If conflict persists and begins to undermine social relationships amongst coresidents, new ways of organising and remunerating labour may be canvassed.

While labour and remuneration disputes do occur on wok bung blocks, they are contained by the leaseholder. Multiple household blocks that continue to work together successfully in a wok bung or 'mixed' strategy can generally be described as cohesive family units, where interhousehold cooperation and sharing remain important. On such blocks, cooperative labour strategies also extend to other areas of life. For example, these families commonly employ communal labour strategies in food production and cooperate to establish and manage small businesses by pooling labour and capital. Disputes over labour and income rarely disrupt oil palm production or other economic activities. Such high levels of cooperation often depend on the skilful management and organisation of labour by the head of the block, and his leadership and authority rarely being challenged. Indeed, when power relationships are destabilised, for example by the death of a leaseholder, it is not uncommon for social relations to begin to unravel, with a consequent rise in 
social conflict. Destabilisation may trigger multiple household blocks to shift to the markim mun strategy. Thus, the decision as to whether or not to switch harvesting strategies depends to a considerable extent on household social dynamics, particularly issues of leadership, power and authority.

Smallholders are not necessarily driven to adopt markim mun by a desire to raise production. More often the switch in production strategies is an outcome of their immediate efforts to reduce conflict among family and kin, and this can lead to lower production. For example, if markim mun emerged in response to prolonged and destabilising conflict between co-resident households, often the family whose month it is to harvest cannot call on other co-resident households for labour with the result that they are unable to complete a full harvest. The total income and production for the block is therefore less than it would be under a communal, wok bung or 'mixed' strategy. Yet, for most block residents, particularly women, a shift to markim mun represents a successful innovation if it leads to a reduction in the level of social conflict among co-residents of a block.

That smallholders sometimes sacrifice production for desired social outcomes is understandable given the cultural beliefs concerning the role of social relationships in the welfare of individuals and groups. In many Papua New Guinean societies, social conflict within the group is often perceived to be a cause of illness and poor health, particularly among children (Hamnett and Connell 1981; Connell 1997; Koczberski and Curry 1999). It is also believed to result in poor subsistence production (food crops and animal husbandry), and in the modern context reduced yields of cash crops such as oil palm and the failure of chicken projects, tradestores and other businesses (Curry 2003). Thus, social conflict has serious repercussions, with considerable ramifications for the welfare of the group. In a village setting, when conflict occurs between brothers, lineages or subclans, the extended family will exert pressure on the antagonists to reconcile their differences through exchanges of food and wealth items. Such exchanges often ripple out through wider networks of exchange as more distant kin are drawn in to support the exchange and process of reconciliation. On the LSSs, where social and kinship networks tend to be truncated, social conflicts can persist for prolonged periods. This often causes considerable distress to family members; especially women, whose responsibility for children and food production makes social conflict particularly distressing. The pressure to adopt the release valve of the markim mun strategy can therefore become irresistible.

\section{Rising aspirations and ambitions}

As we have argued, the shift to a markim mun strategy represents a move to more market-oriented and individualistic production, with a corresponding decline in the importance of indigenous economic and social relationships characterised by reciprocal and in-kind labour. This change is being driven primarily by a younger generation of men no longer content with the 'old ways'. Better educated than their fathers' generation and living in an increasingly commodified economy, secondgeneration settlers now expect and demand to be paid market rates for their labour. 
A conjunction of social changes, especially rising material aspirations and revised notions of kinship, are leading younger men to challenge the authority of their fathers and to question 'traditional' cultural norms and values that mediate labour organisation and remuneration. In particular, young married men desire financial autonomy and greater control over oil palm income to meet their household needs, and to create what Li (1999: 33) terms their 'imagined futures'. Their imagined futures often include leasing their own blocks, living in permanent houses, education for their children, visiting distant relatives and founding successful businesses. While such desires for reform of economic relations are latent among many young men on wok bung blocks, these desires cannot often be realised because the head of the block (their father) still exercises considerable authority and power. While part of his authority is morally sanctioned by indigenous socioeconomic values, such as those associated with gift exchange, the ultimate source of this power resides in his legal title to the block and the authority this confers on him as leaseholder. In extreme situations of conflict, some leaseholders have exercised this ultimate authority by evicting a persistently 'troublesome' son or by selling their leases and returning 'home' to live out their retirements, leaving their sons without land or incomes.

While the demands of a younger generation for reform of economic relations in oil palm production partly relate to changing material aspirations associated with modernity and the market, there remains an element of 'bigmanship' in their demands, a 'bigman' system being one where leadership is said to be achieved rather than ascribed, in contrast to Polynesian chiefly societies of inherited rank (for further discussion see Sahlins 1963; Feil 1987; Lederman 1990; Lepowsky 1990). Previously, strategies for achieving and retaining bigman status were located in the indigenous realms of warfare, gardening, indigenous exchange and organising and staging large ritual events. Today, the arena of competition has broadened to accommodate new introductions in the political and economic realms, such as education, wealth accumulation, business ventures, politics, positions in community, church or oil palm organisations and managing and controlling oil palm production (see Connell 1997: 246-51). For example, the position of leaseholder not only allows an individual to control the flow of oil palm labour and income, but it also carries with it social capital that adds to their status in the settlement community and their own ethnic group. Therefore, leaseholders are reluctant to divest power and decision-making to their sons, and many strongly assert that it is their right as leaseholder to hold authority over the allocation of work tasks and oil palm income. Frequently, they articulate this view by referring to their individual achievement of acquiring the leasehold block. Their feelings are summed up in the comments of one elderly leaseholder, Raphael: 'This block belongs to me alone. I obtained and planted the block. Moreover, the work on this block was done only because I organised it'. Thus, demands for more control over oil palm production made by an aspiring generation of young men, ambitious to make their mark in the broader community, are sometimes fiercely resisted by leaseholders, in much the same way that 'traditional' bigmen tried to maintain their status in the face of competition from younger men. 
If a leaseholder resists innovation, the block can enter prolonged periods of social conflict and instability when a resident (usually a son) persists in destabilising and undermining the economic power and dominant position of the leaseholder (his father). In such situations, the wok bung strategy can persist and full harvesting may still be attainable, provided that enough residents continue to recognise the authority of the leaseholder and remain committed to wok bung. The shift from wok bung to markim mun is not contingent on the collapse of the former production strategy; rather, it occurs when social conflict reaches intolerable levels for most residents that the impetus for change gains momentum and is more likely to succeed. The power struggles between fathers and sons and between brothers for status and authority pose risks for block residents because of the potential for disintegration of social relationships. Therefore, the effectiveness of social conflict for inducing change in the direction of more individualistic and market-oriented production depends to a considerable extent on the leadership qualities of the leaseholder and his ability to exercise authority, manage conflict effectively, and skilfully evaluate the risks for the broader group of not innovating. Although the leaseholder himself stands to lose status and economic power by innovating, and oil palm production may fall, the social risks of not innovating may ultimately become too great to ignore.

\section{Conclusion}

In response to Brookfield's (2001a and 2001b) call to broaden the intensification debate, this chapter has examined some of the complex processes facilitating agricultural change amongst oil palm smallholders in PNG. Change is the outcome of interplay of population growth and changing socio-cultural factors, set within a fairly rigid institutional and commercial framework. The LSSs were established on the basis of individual lease holdings over fixed areas of land and a set of land tenure regulations that specified not only the cash crop to be cultivated but also the area of land reserved for food production. Under such rigid constraints on production there is no scope for crop substitution and little opportunity for supplementary cash cropping in the land area reserved for food gardens. Thus, when population and economic pressures emerged over time, the range of agricultural responses open to smallholders was limited. Intensification of labour and other inputs such as fertiliser are options, but they have only been pursued by smallholders to a very limited extent.

Within this rigid institutional framework, the conventional communal wok bung production strategy, which dominated smallholder production until recently, came under pressure on several fronts, not least by the demands and aspirations of a generation of younger men who began challenging the foundations upon which wok bung relied: centralised control over labour and income and the indigenous norms and obligations associated with labour and exchange. Consequently, a younger generation of men have sought to innovate oil palm production through reorganising labour arrangements and payments. The markim mun strategy, with its rotation of harvesting and remuneration among co-resident households, is spreading steadily in the densely populated Hoskins and Bialla oil palm LSSs. It 
appeals to younger married men who have established their own households on their parents' block because it is closer to meeting their needs and aspirations, and it enables individual co-resident households to control and organise their own production.

An element of continuity is embedded within these new aspirations of younger men. Many are striving for a form of bigman leadership status but are blocked by the position and authority of their fathers in oil palm production. Traditional labour practices like wok bung, where control of labour is centralised and labour value is mediated by indigenous cultural norms and values rather than market values, serve to reinforce the central position and authority of their fathers in oil palm production. By demanding market rates of return for their labour, and by other more direct challenges to their fathers' authority, young men are contesting the indigenous labour practices and values that constrain realisation of their ambitions. The switch to markim mun weakens the authority of their fathers by removing them from the centre of labour organisation and remuneration. This opens up spaces for sons to pursue their own socio-political and economic ambitions.

Not all multiple household blocks have adopted the markim mun strategy, which raises the question of under what circumstances do blocks shift from wok bung to markim mun? The answer hinges on the household dynamics affecting everyday decision-making and social relationships. Innovations in oil palm production illustrate the importance of micro-social processes operating within households and how they interact with the broader social context of change to influence the direction and nature of agricultural change. In the 30 years since the establishment of the LSSs, PNG has undergone significant social change that has precipitated the transformation of social and cultural institutions and altered the attitudes, values and desires of a new generation of smallholders. Yet within this changing social context, the older men (the leaseholders and fathers) are resistant to these broader influences and want to retain their 'traditional' leadership and authority over their sons and their economic power and dominant position in oil palm production. Thus, oil palm production has become a site of conflict, negotiation and power struggles between a younger generation attempting to erode the centralised power and authority and their fathers who stand to lose from agricultural innovation. In short, a shift in production strategies says as much about intergenerational power relations and household socio-political processes as it does about agricultural change and population pressure.

For leaseholders, a shift to markim mun means a diminution of their authority in oil palm production and an erosion of their socio-political role in daily decisionmaking, particularly their position at the centre of exchange relationships on their blocks. For many leaseholders, therefore, there is a disincentive to innovate. However, in their final analysis, and albeit reluctantly, many older leaseholders are prepared to innovate to lessen social conflict on the block and thus avoid the social consequences that may arise from not innovating. Their decision to innovate may be swayed by family members not involved directly in the conflict. Smallholders are acutely aware that the maintenance of social relationships is especially important now that off-block residence and employment opportunities are limited. For most 
smallholders, the 6-hectare block represents their only security in the increasingly uncertain national economy. Former LSS residents living in precarious situations, such as on a friend's block, in 'squatter' settlements or on insecure 'purchased' customary land, after voluntarily or involuntarily leaving the family block because of ongoing conflict, are a constant reminder to settlers of the damaging material effects of prolonged social conflict.

While it could be argued that the innovations in production arising from the presence of social conflict are an outcome of population pressure (a Boserupian interpretation), this is too simple. Broader factors are at play at the community and household levels, and the presence of a larger block population creates an environment in which these other factors are more likely to result in change. Placing the household at the centre of the analysis casts light on these issues. However, the adoption of a markim mun strategy does not sit comfortably with Brookfield's notion of innovation leading to higher production and incomes. The switch from wok bung to markim mun can lead to lower labour productivity and production than if all residents cooperated in oil palm production by pooling their labour. The 'mixed' strategy, involving the deployment of communal interhousehold labour for harvesting and rotating the monthly payments amongst households, is probably the most efficient in terms of labour productivity and leads to the highest production and income for the block. But it has been adopted by only a small minority of blocks. While Brookfield acknowledges that not all innovation is successful and the effect of failure may be a reduction in the productivity of labour, for many smallholders the sacrifice in production and incomes associated with the shift to markim mun is worthwhile. It is successful as a strategy for reducing conflict and thus lowering the social risks of disintegration of the kinship group.

In this way, innovation is about reducing social risks on conflicted blocks. While we agree with Brookfield that the main purpose of innovation is to reduce agricultural risk, his concept of risk could be usefully extended to include social risk to help explain processes of agricultural change among oil palm smallholders. Social risk in smallholder oil palm production arises from a conjunction of factors involving a younger generation's material aspirations that are more closely aligned with market values, mixed with an ambition and desire to achieve the status and renown associated with managing oil palm production. Social risk heightens as these desires are resisted by an older generation of leaseholders, whose source of authority, power and status is dependent on keeping oil palm production within the indigenous realm of labour and kinship obligations with themselves at the centre. In this contest between generations, between leaseholder and ordinary block resident, between the individual and the group, between modernity and tradition and between market and indigenous economic relations, social risks are heightened and the efficacy of social conflict for influencing the nature and direction of agrarian change increases.

\section{Note}

1 Data are drawn from 2001-02 fieldwork conducted as part of a smallholder socioeconomic study among oil palm leaseholders in West New Britain. The study was a 
collaborative project between the Department of Human Geography of the Australian National University, Papua New Guinea Oil Palm Research Association and Curtin University of Technology. The study was funded by the Australian Centre for International Agricultural Research.

\section{References}

Adams W and Mortimore, M (1997) Agricultural intensification and flexibility in the Nigerian Sahel, Geographical fournal, 163, 150-60.

Bilsborrow, R (1987) Population pressure and agricultural development in developing countries: a conceptual framework and recent evidence, World Development, 15, 183-203.

Boserup, E (1965) The Conditions of Agricultural Growth: The Economics of Agrarian Change Under Population Pressure, London: Allen and Unwin.

Boyd, D (1985) The commercialisation of ritual in the Eastern Highlands of Papua New Guinea, Man, 20, 25-340.

Brookfield, H (1972) Intensification and disintensification in Pacific agriculture: a theoretical approach, Pacific Viewpoint, 13, 30-48.

- (1984) Intensification revisited, Pacific Viewpoint, 25, 15-44.

- (2001a) Exploring Agrodiversity, New York: Columbia University Press.

- (2001b) Intensification, and alternative approaches to agricultural change, Asia Pacific Viewpoint, 42, 181-92.

Carrier, J and Carrier, A (1989) Wage, Trade, and Exchange in Melanesia. A Manus Society in the Modern State, Berkeley, CA: University of California Press.

Connell, J (1997) Papua New Guinea: The Struggle for Development, London: Routledge.

Curry, G N (1997) Warfare, social organisation and social organisation and resource access amongst the Wosera Abelam of Papua New Guinea, Oceania 67, 194-217.

(1999) Markets, social embeddedness and precapitalist societies: the case of village tradestores in Papua New Guinea, Geoforum 30, 285-98.

-(2003) Moving beyond post-development: facilitating indigenous alternatives for 'development', Economic Geography, 79, 405-23.

- and Koczberski, G (1998) Migration and circulation as a way of life for the Wosera Abelam of Papua New Guinea, Asia Pacific Viewpoint, 39, 29-52.

(1999) The Risks and Uncertainties of Migration: an exploration of recent trends amongst the Wosera Abelam of Papua New Guinea, Oceania, 70, 130-45.

Feil, D K (1987) The Evolution of Highland Papua New Guinea Societies, Cambridge: Cambridge University Press.

Goddard, M (1995) The rascal road: crime, prestige and development in Papua New Guinea, The Contemporary Pacific, 7, 55-80.

Guyer, J (1997) Diversity and intensity in the scholarship on African agricultural change, Reviewes in Anthropology, 26, 13-32.

Hamnett, M and Connell, J (1981) Diagnosis and cure: the resort to traditional and modern medical practitioners in the North Solomons, Papua New Guinea, Social Science and Medicine, 15(B), 489-98.

Hulme, D (1984) Land Settlement Schemes and Rural Development in Papua Nerw Guinea, unpublished $\mathrm{PhD}$ thesis, Queensland, James Cook University.

Imbun, B (2000) Mining workers or 'opportunist' tribesmen? A tribal workforce in a Papua New Guinea mine, Oceania, 71, 129-49.

Koczberski, G and Curry, G N (1999) Sik bilong ples: an exploration of meanings of illness and well-being amongst the Wosera Abelam of Papua New Guinea, Australian Geographical Studies, 37, 230-47. 
(2003) Creating viable livelihoods amongst oil palm smallholders in Papua New Guinea, in Metz, O., Wadley, R. and Christensen, A.E. (eds), Local Land Use Strategies in a Globalizing World: Shaping Sustainable Social and Natural Environments, Copenhagen: Conference Proceedings, University of Copenhagen, Denmark, 4, 107-29.

- and Connell, J (2001a) Full circle or spiralling out of control? State violence and the control of urbanisation in Papua New Guinea, Urban Studies, 38, 2017-36.

— and Gibson, K (2001b) Improving Productivity of the Smallholder Oil Palm Sector in Papua New Guinea: a socio-economic study of the Hoskins and Popondetta schemes, Canberra: Australian National University, Department of Human Geography, Research School of Pacific and Asian Studies.

Landell Mills Ltd. (1991) Smallholder Oil Palm Productivity Study, Volume 1: Main Report, Bath: United Kingdom.

Lederman, R (1990) Big men, large and small? Towards a comparative perspective, Ethnology, 24, 3-15.

Lepowsky, M (1990) Big men, big women, and cultural autonomy, Ethnology, 24, 35-50.

Li, T (1999) 'Marginality, power and production: analysing upland transformation' in $\mathrm{T} \mathrm{Li}$ (ed.), Transforming the Indonesian Uplands. Marginality, Power and Production, Singapore: Harwood Academic Publishers and Institute of Southeast Asian Studies, pp. 1-44.

Maclean, N (1989) The commoditization of food: an analysis of a Maring market, Canberra Anthropology, 12, 74-98.

Morrison, K (1996) Typological schemes and agricultural change: beyond Boserup in precolonial South India, Cultural Anthropology, 5, 331-36.

Mortimore, M (1967) Land and population pressure in the Kano close-settled zone, Northern Nigeria, The Advancement of Service, 23(118), 677-86.

Netting, R M (1993) Smallholders, Householders, Farm Families and the Ecology of Intensive, Sustainable Agriculture, Stanford, CA: Stanford University Press.

-Stone, M P and Stone, G (1989) Kofyar cash cropping: choice and change in indigenous agricultural development, Human Ecology, 17, 299-319.

Neumann, K (1997) Nostalgia for Rabaul, Oceania, 67, 177-93.

Nihill, M (1989) The new pearlshell: aspects of money and meaning in Anganen exchange, Canberra Anthropology, 12, 144-61.

Sahlins, M (1963) Poor man, rich man, big man, chief: political types in Melanesia and Polynesia, Comparative Studies in Society and History, 5, 285-300.

Stone, G (1998) Keeping the home fires burning: the changed nature of householding in the Kofyar homeland, Human Ecology, 25, 239-42.

(2001) Theory of the square chicken: advances in agricultural intensification, Asia Pacific Viewpoint, 42, 163-80.

Tiffen, M, Mortimore, M and Gichuki, F (1994) More People, Less Erosion: Environmental Recovery in Kenya, Chichester: John Wiley.

Turner, B, Hanham, R and Portararo, A (1977) Population pressure and agricultural intensity, Annals of the Association of American Geographers, 67, 384-96.

Turner, B, Hyden, G and Kates, R. (eds) (1993) Population Growth and Agricultural Change in Africa, Gainesville, FL: University Press of Florida.

Zimmer-Tamakoshi, L (1997) Everyone (or no one) a winner: Gende compensation ethics and practices, in S Toft (ed.), Compensation for Resource Development in Papua New Guinea, Pacific Policy Paper No. 24, Canberra: National Centre for Development Studies, pp. 66-83. 


\title{
8 Holding on to modernity? Siwai, Bougainville, Papua New Guinea
}

\author{
John Connell
}

Nothing is permanent but change.

(Heraclitus)

The Siwai people, now about 14,000 in number, occupy part of the dissected southern plain of Bougainville, the easternmost island of Papua New Guinea (PNG) (Figure 8.1). At the end of the 1930s the American anthropologist Douglas Oliver lived there for eighteen months and subsequently wrote $A$ Solomon Island Society (1955). The book eventually became a classic anthropological text, both because of the detailed ethnography and the description of leadership, which provided a seminal account of a 'bigman' society. I first visited Siwai in 1974, similarly remaining for eighteen months, and revisited it for much shorter periods of between a week and a month in 1981, 1988 and 2001. ${ }^{1}$ There has therefore been a fragmented, though broadly continuous, analysis of Siwai society and economy over a sixty-year period, a situation that is unusual in Melanesia. Given what many have perceived as a proliferation of ethnographic and other studies in Papua New Guinea, remarkably few longitudinal studies have been undertaken there (cf. Brookfield 1973, Brown, Brookfield and Grau 1990, Gewertz and Errington 1991, Harrison 2001, Knauft 2002, Read 1986, Smith 2002) and most have limited parallels with Bougainville.

This chapter examines the trajectory of development over that sixty-year period, but particularly over the past quarter of a century. During that later period Siwai became a region of considerable affluence, based on a combination of cash cropping and distant wage and salary labour, but plunged back to a subsistence society during the decade-long Bougainville Crisis. After the conflict the people of Siwai again sought to construct a structure of successful development. The chapter therefore seeks to account for both stability and change in development by undertaking a long-term analysis of rural change that responds to both demands for the comparative method and for re-studies of village change (Brookfield 1962, Connell 1973). It examines how Siwais constructed notions of change and modernity at different times, and how and why changing perceptions and strategies have occurred in a context of continuity as much as change. 


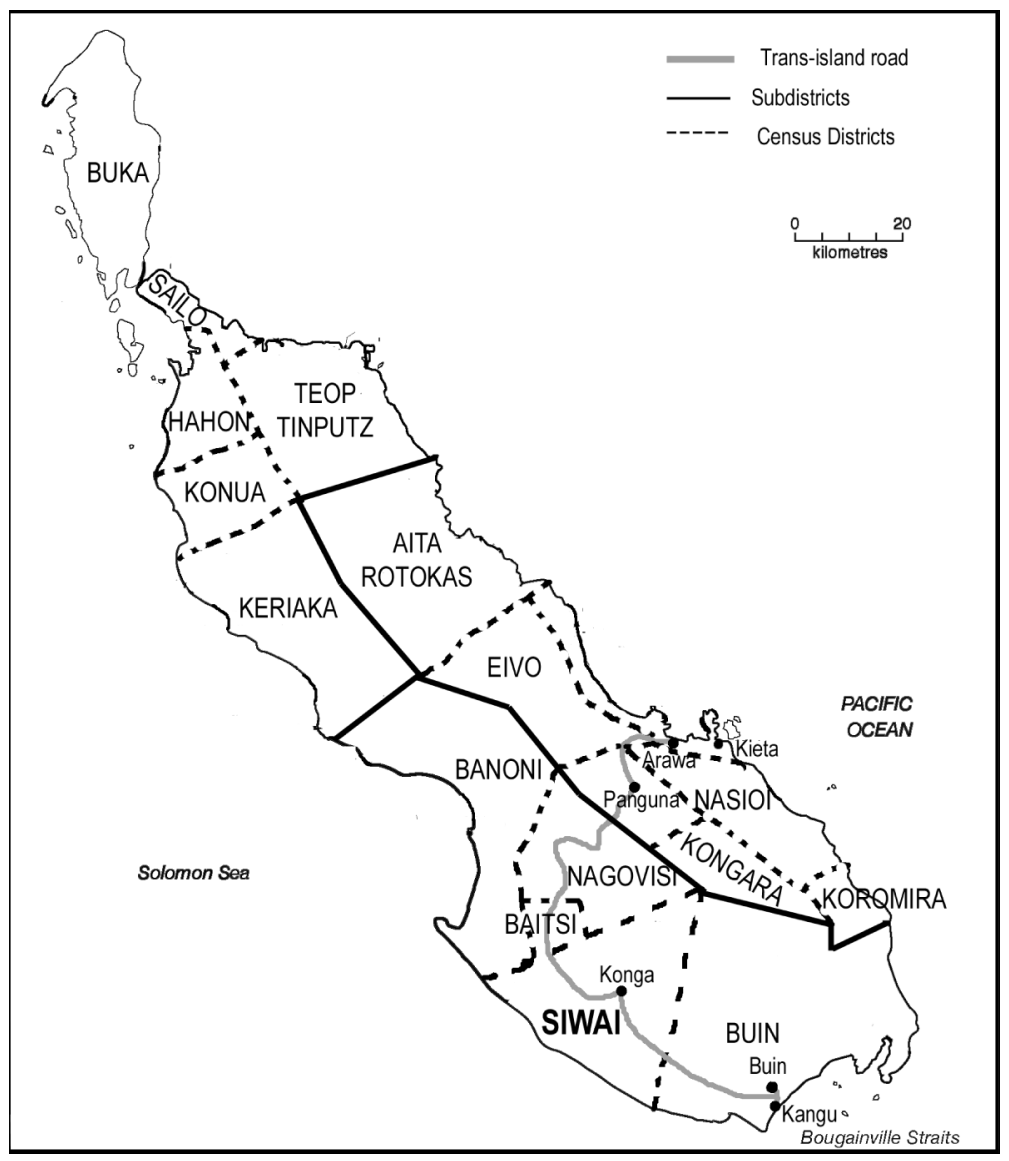

Figure 8.1 Siwai, Bougainville, Papua New Guinea.

\section{An old order?}

The first limited external contact came around the late nineteenth century in south Bougainville. Christian missionaries established themselves in the 1920s, at much the same time as the Australian colonial administration. By then there was an established history of contact, most evident in labour migration to east coast plantations and in administration-enforced new nuclear villages.

In the immediate post-war years, mainly through labour migration, Siwai had become a monetised society but on the very margins of the global economy. People had little to trade, other than tiny quantities of copra, and what cash reached the region principally came from distant plantation labour. Cash was essential for paying taxes and obtaining the few items (tools, clothes, etc.) that had become both desirable and necessary. An incipient cash economy was thrust upon them, though it unquestionably met emerging needs and desires. Siwais indirectly traded 'shell 
money' from Malaita, three hundred kilometres east in the Solomon Islands. To a greater extent than in most other parts of Melanesia, that shell money actually had the characteristics of money and, as in East New Britain, enabled a form of 'protocapitalism' that made the eventual transition to capitalist relations of production rather easier to achieve (Connell 1997: 246-49).

In the interwar years there was minimal administration interest in this distant island and remote parts of Bougainville were only contacted in the 1930s. Although the earlier German administration had insisted on ten coconut palms per head being planted throughout the colony, there was never enough copra or traders to ensure a significant income from that. Nor were there roads or markets: no supply and no demand. Changes to the agricultural system were engendered more by the missions than the administration, and succeeded only because of indigenous enthusiasm for new plant and animal species.

Siwai remained in large part a subsistence economy, centred on root crops (mainly taro), pigs and some degree of hunting and gathering. Despite isolation from much of the colony and the wider world, certain key changes had occurred. Money was welcomed because of the opportunities it provided. One such opportunity was the purchase of rice (and other goods) from the tiny administrative post of Buin, some thirty kilometres to the south. Rice, the staple food consumed on alien plantations, was seen as a prestigious good and had become a key component of feasts and a measure of some degree of modernity and sophistication.

\section{Gocoa and capitalism}

The Second World War brought an end to the limited modern development that had reached Siwai, as the island was occupied by Japanese forces and later by allied forces. The trivial cash economy disintegrated, many Siwais were forced to flee their villages and some worked for the Japanese on food gardens established after supply lines with Japan were cut. In the post-war years Siwais actively experimented with cash cropping. The transition from taro to sweet potato, brought on by taro blight (Connell 1978a), had released labour and the Japanese 'model' seemed to offered the real possibility of greater self-reliance in income production rather than dependence on poor wages, and alienating experiences, in distant plantations (Connell 1978b). At the same time superior income generation would allow improved access to necessary consumer goods and give prestige and status to successful innovators.

Curiously, more than almost any other group in Bougainville, Siwais were frequently described by administration patrol officers (kiaps) as particularly enthusiastic for 'modern development'. Invariably this referred to a desire for cash cropping. Various crops were tried after the war, including rice, peanuts, corn and coffee, all relatively new introductions. Distant, unfamiliar markets meant that, though surpluses could be produced, most rotted, were eaten or fed to animals.

A combination of improved infrastructure (as a road from the far south coast was constructed to Siwai), administration pressure (notably from one unusually enthusiastic agricultural extension officer), mission support and local pressure eventually 
enabled the successful establishment of cocoa in the 1960s (Connell 1978b). Despite concerns over the time period required for cocoa to bear, its semipermanent occupation of land and its inability to be directly consumed, labour availability, the low cost of its introduction and appropriate existing skills ensured that Siwais continued to experiment, even for what seemed the least promising of the various new possibilities. Cocoa thrived on shade, coped with heavy rain, was easy to produce and market and world prices were high. By 1970 cocoa was already a major success story, with market access the ultimate key to that success. My very first meeting on arrival in Siwai in 1974 was delayed for a few minutes as the Chairman of the Local Government Council, Anthony Anugu, first listened to world cocoa prices on the radio while quickly making computations on his electronic calculator.

The success of cocoa brought new forms of local economic differentiation. Larger growers often constructed fermentaries and they and other traders ('privates') bought small quantities of cocoa from those with smaller holdings. Selling the resultant dry bean resulted in prices roughly three times those of the unprocessed wet bean. Large growers and traders went on to invest in stores and trucks as they became small entrepreneurs. Some sought other forms of investment, including urban stores (on the other side of the island), 'cinemas' (showing videos in the open air), garages (for petrol sales and vehicle repair) and so on. Throughout this period there was a constant concern for diversification and other alternatives, because of the earlier 'failures'. Cattle, rubber and even teak all had their moments during the 1960s and 1970s - a measure of the diversity that was possible in a relatively benign and fertile environment - as interest in innovation continued.

In parallel with the success of cocoa, the local and regional economies expanded and diversified. Greater administrative interest had brought roads, schools and aid posts to the area, and these required skilled and other labour. Most dramatic of all was the construction of the Panguna copper mine, sixty kilometres away, which began in 1969. By 1972, when it first exported minerals, it directly employed 4,000 workers, with at least that number again in ancillary activities, from catering to recreation. Like other Bougainvilleans, to whom preference was given, many Siwais took up the prestigious and very well paid jobs, and some of that income trickled down and flowed back to Siwai. One condition of mine construction was that a trans-island road be created. That road brought Siwai direct access to the mine and to east coast towns and the port, enabling substantially increased cocoa incomes in real terms and bringing new access to mine markets (for fresh food and handicrafts), high schools, hospitals, etc. A rural area that had been on the fringes of the nation and the world economy was no longer remote.

\section{'We're all millionaires now'}

By the mid 1970s, after a decade of extraordinarily rapid change, there was not only a considerable diversity of income sources in Siwai, but also some of these, particularly cocoa growing and mine employment, generated substantial cash 
incomes. Most households by then had several hundred cocoa trees, which earned them $\mathrm{A} \$ 250$ to $\mathrm{A} \$ 300$ per year. Where households combined these possibilities, and might also produce copra or handicrafts, sell food in expanding local markets (including that of the mine) or have some local employment, incomes were substantial. Money seemed to grow on trees (Brookfield 1968), in the bush and on the ground. By the time the mine opened, plantation employment had become a thing of the past (other than for a few individuals in managerial and technical capacities), to the extent that some Siwai households who had become most committed to market operations were actually hiring workers, several of who came from poorer parts of Papua New Guinea.

Household incomes in the mid-1970s averaged much more than $\mathrm{A} \$ 500$ and, in a context where the agricultural system continued to provide most food needs, usually enabled some degree of savings. Such incomes were somewhat higher than in most Melanesian villages at that time (Connell 1997, Smith 2002). In two reasonably typical villages some nine out of forty eight households were earning more, sometimes much more, than $\mathrm{A} \$ 1,000$. Elsewhere in Siwai some cocoa growers were earning more than $\mathrm{A} \$ 10,000$, through larger holdings, hired labour and regular market participation. Those who diversified into stores and transport businesses were earning profits of over $A \$ 50,000$ per year. Since no household had earned $\mathrm{A} \$ 10$ a year from agriculture in the 1950 s this was a substantial change. Cargoism, once significant in several Siwai villages (Connell 1978b), seemed to have become a thing of the past, as wealth seemed to have become detached from any supernatural foundations.

Few had missed out from this rapid income growth, though the changes had little to do with equity. There seemed good reason to be optimistic over the future, hence in 1976 I had confidently written:

Bougainville's successful economic future is assured. Ever increasing areas of cocoa, backed by copra, provide a solid permanent basis for economic development and enable the benefits to reach every household. ... rapidly rising educational standards seem likely to ensure that these assets can be developed adequately and the income invested to secure the future.

(Connell 1976: 654)

At that moment of euphoria even Rostow's notions of self-sustaining growth appeared validated. A recent history of dependence on the outside world seemed to be giving way to a measure of successful interdependence. At the same time Siwai was gradually becoming more dependent on commodity prices, both the price of copper, which influenced profitability and wages at the mine, and, in particular, the price of cocoa. Such dependence then seemed innocuous. Though there had been short-term fluctuations in prices, there appeared little likelihood of a slump, while all the cash crops previously grown successfully in Siwai remained potential substitutes if necessary. Indeed, Siwais were price responsive; when copra prices rose, short-lived copra production temporarily took the place of cocoa.

Yet even cocoa, with its high prices, ability to be locally processed (up to a point) 


\section{John Connell}

and suitability to the local environment, was merely one more agricultural commodity. Prices could never be assumed to continue to spiral upwards, as Siwais had become an affluent yet 'terminal peasantry' (Howlett 1973) primarily dependent on the land. However, one consequence of changes across the island was the move of many Siwais into town, primarily as a direct or indirect response to the development of the mine (Connell 1988). In large part this was an obvious response to superior skilled employment opportunities elsewhere, but in some part it was recognition by some that a better future might lie in urban employment. The 'fast' and regular income from wages and salaries, enabling a permanent house and store food, improved on cash crop incomes, however large they might be. Siwai could no longer be conceived as a wholly rural society.

By the 1980s the boom years were in full swing. Global cocoa prices had risen, village plantations had expanded, all households grew cocoa and the future seemed secure. The title of this section was one gleeful theme of Anthony Anugu, by then the national Member of Parliament for South Bougainville. Though he well knew there was considerable hyperbole in the statement, it was evident to all that a very different economy existed from that of a couple of decades earlier. Consumerism had been enhanced; vehicles and alcohol - still novelties in the early 1970s - had become commonplace.

One consequence of these changes was new structures of differentiation and inequality within Siwai. To a substantial extent younger men had replaced older more traditional men as the new leaders of society. New inequalities were quite different from the somewhat hierarchical system that characterised pre-war years (Oliver 1955). Younger men were schooled in 'alien' knowledge, from the English language to accountancy and technology, and saw progress as being through capital acquisition as much as through the demonstration of leadership by more traditional means (such as the sponsoring of feasts or the construction of men's houses). Local knowledge, whether of medicine (Hamnett and Connell 1981), hunting techniques or simply legends, was giving way to what was once alien school knowledge. The use of 'shell money' for critical transactions involving land, wives, pigs, etc., was gradually replaced by the use of money. There was a sustained flourish of the 'old order' in the 1970s - as older men gained new incomes and sought to restore their primacy through reinventing tradition (Hobsbawm 1983, Sahlins, 2005), reviving old ceremonies, constructing new men's houses and sponsoring larger feasts, all of which necessitated expanded pig husbandry - but that renaissance faded as power passed to the relatively young.

Those who had been particularly successful sought to capitalise on their success through establishing such organisations as the Siwai Cattlemen's Association and the South Bougainville Chamber of Commerce (the latter, despite its title, being essentially a Siwai phenomenon). Such organisations were intended to secure their members better access to markets, goods and trading opportunities, though these hints of incipient class formation did not last long. Their emergence, however, coincided with a shift in the structure of economic organisation from cooperative groups, which were established in many villages to collectively develop cash crops, to individual holdings. Similarly, the initial power of the Siwai Cooperative was 
declining as individual entrepreneurs were able to bypass cooperative efforts in their desire for larger incomes. It finally closed in the late 1980s as fewer and fewer Siwais were marketing through the cooperative; most produced dry bean themselves or sold to a village entrepreneur (who was willing to collect the cocoa from the villages). Significantly, the Cooperative invested what capital it had retained in urban property in Arawa.

By then a more modern economy was firmly established. Yet not all had benefited, and those who gained least from these changes were older people and the occasional female-headed household. Gender divisions had changed somewhat as men took over the ownership of the valuable cocoa plantations, with women remaining the principal (now sometimes the only source of) garden labour. The new incomes therefore went primarily to men. As one older man told me in 1981, 'when you first came we still had our customs; now they have all given way to money': the taim bilong mani. Not that they had, but it was symptomatic of a degree of disillusionment with the pace and orientation of change, the relative exclusion of older people from some of its benefits, the loss of power and status of the old and even the movement of power and authority away from Siwai itself as it became part of a wider economic, political and social world.

There had been a shift away from cooperative labour (hence older people's needs, such as house repair and building, were less likely to be taken care of collectively), a greater degree of materialism (manifest in the greater likelihood of wages being paid to local workers, rather than 'payment' through - and the assumption of - reciprocity), competitiveness (for example over access to land and labour) and individualism. Labour and land were more likely to be seen as commodities. Even time itself was increasingly perceived as a scarce commodity, with the phrase 'wasting time' being a loan word within the local language (see also Smith 2002: 45), though those who hung lanterns in the trees, to work on their cocoa by night, were usually regarded as being far too diligent.

At the same time certain problems of rapid economic growth had begun to emerge. The steady expansion of cocoa intensified pressure on land resources. By the mid-1970s some matrilineages, especially in the central Korikunu area of Siwai, were becoming short of land. In some exceptional instances cocoa was cut back to allow food production when prices declined, as also occurred in neighbouring Nagovisi (Mitchell 1982), and opportunities for expansion of holdings were already few. Demand for land had inevitably increased, and as land was inherited through women some individuals negotiated more strategic marriages and second marriages (as polygyny revived) to gain superior land access. Conflicts over land intensified, and were more regularly the subject of village court hearings. In some rare circumstances, usually where a sole owner remained, land was bought and sold (an impossibility in pre-war years).

Land disputes had incidentally increased the demand for Oliver's book, long out of print, which was believed to have recorded the definitive structure of land ownership. By the end of the 1980s just a handful of copies remained in Siwai. I occasionally saw copies - usually carefully wrapped to preserve against further disintegration - and it was frequently referred to, with some pride and no hint of 
irony, as the 'bible' of Siwai life and a means of resolving land disputes. ${ }^{2}$ In 1975 , during the renaissance of 'tradition', in a sense being revisited as empty practice, I was asked to refer to the book to ensure that a particular ceremony was being conducted correctly.

Hitherto land had always been occupied by food crops, and with a relatively stable population in the pre-war years the need for land never changed. As cocoa was planted and the population grew extremely quickly, at around three per cent per year, thus doubling roughly every fifteen years (Connell 1978b), demand greatly increased. Moreover, cocoa was a permanent tree crop, hence whereas land had previously circulated among food producers, now the use of land was increasingly stabilised, creating tension and disputes over the inheritance of tree crops as distinct from the land itself. While disputes over land tended to be between lineages as cultivation margins moved outwards, disputes over tree crops were within the lineage groups and created tensions within extended families. The greater value of both land and trees came at some social cost.

What had become the normal process of initially creating a food garden and subsequently converting that to a small cocoa plantation (after a couple of years of food crops) continued. Gardening thus took place further and further from the nucleated villages, with the initial result that distant gardens received less labour. Where gardens closer to villages were used, their fertility was low, despite intensification through mounding, and cassava (of lower nutritional value, but able to cope with poor soils) became a more common component. One consequence of these changes was that food production tended to stabilise and decline, to the extent that by the 1980s there was considerable evidence of inadequate nutrition at a time of considerable material success - especially amongst preschool children.

Also in the 1980s, the line villages, which had come together through administrative fiat in the 1930s, began to disintegrate as numerous households moved away to what had originally been their hamlet locations before nucleation. They moved to be closer to their land, to be able to work it more effectively than from a greater distance, and to be in residence in the sense that, if there were disputes, possession and residence constituted no small part of the 'law'. Though the line villages were somewhat artificial constructions, their decline marked some degree of community disintegration.

As gardens were constructed further away from villages, primary and secondary forest receded. The extended rate of clearing, both for new agricultural land and for timber, especially to sustain the fermentaries (Figure 8.2), brought erosion and the degradation of streams and the consequent reduction of biodiversity and biomass in those streams. In itself the loss of forest areas meant the loss of species habitats and the declining availability of several species; some, such as sea eagles and hornbills (both of great social significance), were rarely ever seen, while others (such as wild pigs) had become difficult to find. Alongside the ability to purchase store foods (some of limited nutritional value), a significant consequence of rising incomes, both these changes further contributed to a reduction in nutritional status. In a sense, ecological risk now accompanied economic risk as pressure on resources intensified. 


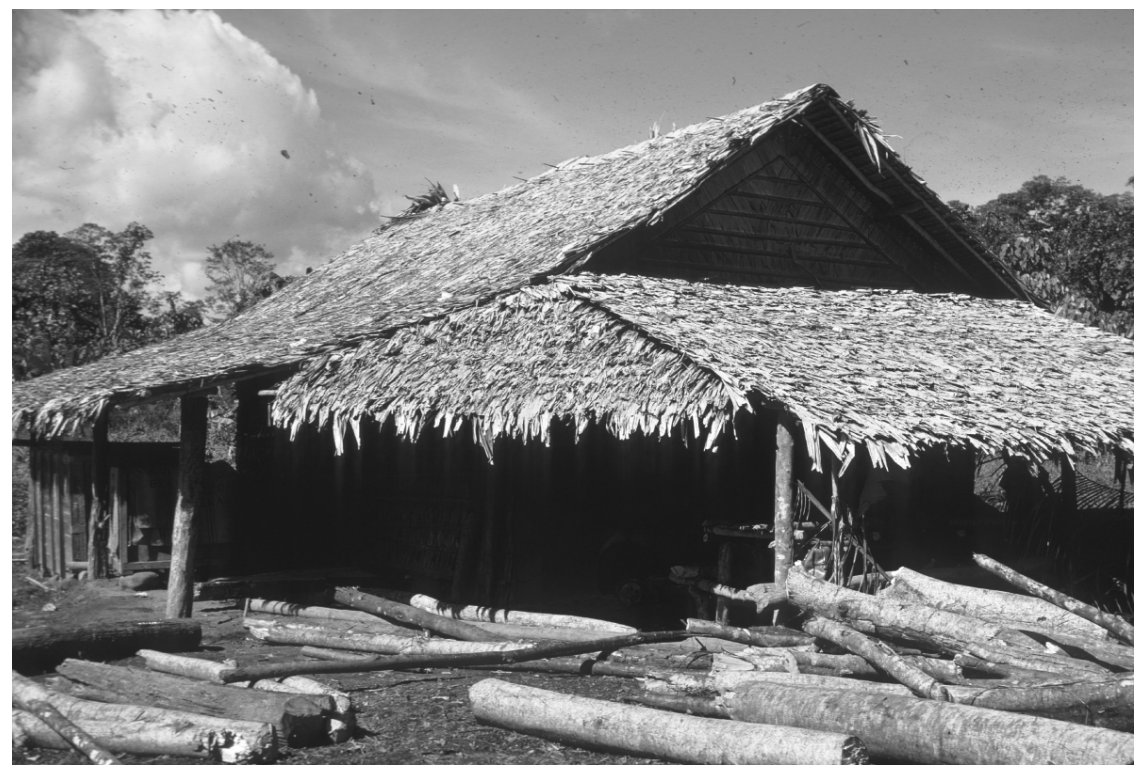

Figure 8.2 Large cocoa fermentaries, such as this one at Hukuha (1975), used enormous amounts of high quality timber.

Some forms of diversification had ended. By the end of the 1980s cattle were no longer reared; they were too much trouble, took up too much land and generated little income. Selling produce to the mine markets had also ended; the earnings scarcely justified the substantial effort in comparison with focusing on high cocoa prices. Local markets had declined; surpluses were smaller, produce was taken direct to Arawa (for higher prices), the markets now included processed and purchased foods from elsewhere (such as eggs and bread), and stores had taken over their role. Hence Siwai had moved somewhat closer towards specialisation. Diversification had not however ended; there were then a couple of small crocodile farms, both novelty and diversity.

Accompanying all these changes were rising expectations. Wants were now likely to be regarded as needs. New processed foods (including alcohol), vehicles, radios and a host of other goods were now normal and expected. Indeed, nothing characterised the early 1980s more than the diverse symbols of modernity that were absent six years earlier: motorbikes, sunglasses, long trousers and even a 'club' (closed during the brief time I was there for infractions of alcohol regulations). By the end of that decade there was a greater permanence to village life, in the sense that houses (and stores and churches) were more likely to be made of permanent materials on concrete foundations, as were stoves and toilets. Generators were a little more common, though kerosene was the most common source of light and wood of heat. 
Team sports, such as volleyball, had brought new links with other parts of the island. These links, some encouraged by the missions and some linked to provincial competitions that followed new affluence, emphasised the wider significance of migration and the expanded social field. An intermittent minibus service connected Siwai to Arawa in a few hours. Fully half of all marriages undertaken in the second half of the 1980s were contracted with a spouse from outside Siwai, a remarkable transformation of the situation in the 1970s, when almost all marriages were made within the same village and choice of partner was constrained by parental pressures.

Any increased emphasis on subsistence agriculture would have been regarded as an unwarranted reversion to an old order that had been willingly left behind. Cash, cars, cocoa and capitalism all represented the new order. A final recollection of leaving Siwai in 1981 was of a youth wearing elegant 'shades', astride a motorbike and wearing a tee shirt emblazoned 'Siwai Angels'. Here, visibly, 'capitalism is so much less an economic machine of domination than a means of seducing the senses, a carnival of goods, an image of the future, a call to arms for the younger generation' (LiPuma 2000: xii).

To the emerging problems of the 1970s - land shortages (and inequalities), growing population pressure on resources, unfavourable terms of trade and rising (and challenging) expectations - could now be added intensified ecological problems (primarily of erosion and reduced fertility). While incomes had grown, some basic needs (such as housing) had improved and life expectancies increased, there was a growing sense that material gains could not so easily be equated with development. The triumphalism of the 1970s was being eroded.

\section{The Bougainville Grisis}

At the end of the 1980s the island experienced unparalleled crisis. Bougainville became the centre of what was later seen as a largely Melanesian Arc of Instability. Disputes over the impact and consequences of the Bougainville mine flared into open violence, resulting in its closure (about half way through its perceived economic life), while landowner disputes expanded into a wider uprising that again demanded the secession of Bougainville from PNG, spearheaded by the Bougainville Revolutionary Army (BRA). In turn this led to civil war (and the temporary blockading of the island) and much loss of life, until a measure of peace was restored in the mid-1990s.

Violence and tensions were particularly complex and localised in Siwai, which had a specific 'Siwai crisis' within the wider crisis (Regan 1998: 279). In the worst years of the conflict, there had been disputes within BRA factions in Siwai, and several parts of Siwai had shifted allegiance from the BRA to the Resistance (founded in Siwai), which sought movement towards normalcy via some rapprochement with the PNG government. Violence was unusually endemic, symbolised by the murders of provincial leader Theodore Miriung in Siwai and of Anthony Anugu (after being captured and taken to BRA headquarters at Panguna). Neither crime was solved and allegations of guilt and complicity have continued to complicate all 
movements towards peace and stability. Many Siwai people were relocated in care centres away from their own villages, and were only sporadically able to engage in agriculture.

Prior to 1989 Siwai was largely divorced from tensions at the mine site, though as the arguments became more familiar Siwais saw themselves as being disadvantaged by the mine in terms of its assumed effects on reduced agricultural productivity and the loss of wildlife (Connell 1991). In Siwai as elsewhere it is probable that agricultural problems were primarily a result of overintensive use of land, as fallowing times had become severely reduced and limited labour was expended on some forms of agriculture (despite food crop cultivation demanding increasingly intensive techniques) whilst population growth was largely unchecked.

At the same time, cocoa prices experienced a global slump at the end of the 1980s. Despite the introduction of new higher yielding varieties (after the first generation of trees were nearing the end of their economic lives), the crisis at the mine was accompanied by problems, if not crisis, in Siwai itself. Two decades of successful cocoa production had reduced interest in diversity (though fish ponds were new, and some had attempted alluvial gold mining in the hills), hence falling cocoa prices represented a new problem. Perhaps for the first time, there was a growing recognition not only that rising affluence could no longer be guaranteed, but also that affluence and development were somewhat separate. As mine workers and other urban residents flooded back into the villages, rural life took on a new primacy.

During the crisis, cocoa cultivation and production stopped (without market access) and holdings were neglected and became overgrown. Gardens continued to be intermittently cultivated, where that was possible, but animal numbers fell (as processed feed was no longer available). However, not only were Siwais well able to support themselves from the land throughout this period, but also health and nutrition actually improved as they did so. Bush medicine too again came into its own. The numbers that died were fewer than predicted, a situation similar to elsewhere in southern Bougainville (Nash 2005), and deaths were more likely to be from conflict than from disease, and certainly not from inadequate nutrition.

Particular skills were learned during that period. Some involved keeping (some) machinery, including vehicles, running on coconut oil, making salt and soap, etc. as self-reliance became absolutely crucial. For at least a couple of years money had little or no value since there was almost nothing to be purchased (except occasional chickens). Composting, hitherto unknown in the lowlands of PNG, was introduced (Bourke and Betitis 2003: 91) to improve agricultural productivity. Links with the Solomon Islands, strengthened during the crisis years, had resulted in the introduction of some new plant varieties, but also the particularly ferocious fire ant (necessitating that toilet seats, in the rare cases where they existed, be approached with caution). A renewed focus on subsistence agriculture had become essential. However, no basic modern skills were being learned as most primary and secondary schools were closed for years. Most children missed years of education, but especially the now young men who had been youthful combatants. The years of violence traumatised many, eroded trust, respect and community, and devastated the decades of peaceful change and evolution. 


\section{Picking up the pieces}

By the mid-1990s the worst was over and there was episodic rehabilitation on the island, made more difficult in the south by the massive disruption in communications. Arawa, once a town of over 20,000 people, was abandoned and overgrown, the mine area was still held by the rump of the BRA and the 'capital' of the island had shifted to Buka in the north, far from Siwai. Gradually, some degree of normality was restored, but by 2001 Siwai remained vastly different from the precrisis years. Few vehicles were left, and there was only one reasonable road (the grandiosely named 'trunk road' from the edge of Nagovisi to Buin) and no effective road access to the mine or Arawa (still something of a ghost town) other than what was now a track that ran through BRA territory at the mine site.

Continued population growth meant that several villages had grown, and the shift back towards hamlets had been halted in some places (because of security reasons and the reduced value of cocoa), despite the possibilities opened up by the need to redevelop land and in some cases re-establish housing. The crisis had taken a major toll on social life. Most villages had lost at least one person from the violence itself - occasionally many more - and sometimes at the hands of a near neighbour (even a fellow kinsman or villager). The reconciliation process was working its way slowly through the villages; long meetings brought old combatants together, but the most difficult issues remained. While reconciliation was going on throughout Bougainville, it was particularly difficult in Siwai because of the localisation of disputes. Youths, without education or wage work, often roamed at will, sometimes assaulting those who stood in their way. Homebrew, or jungle juice' (JJ), made from fermented bananas or pineapples, was literally wasting away village youth. With a civil order yet to emerge, it was even being sold illegally in local markets (where, in comparison with past times, little else was sold).

Superficially there was a veneer of normality. Most trivially, some once smartly dressed Siwais wore rags, though even here a seemingly ubiquitous Manchester United football shirt provided evidence that linkages with the wider world were far from over. All sought such symbolic modernity, in some sense a mark of the end of crisis. Sadly, much of the money that had been hoarded and survived the crisis disappeared into a pyramid scheme (run by a Siwai and eventually a problem throughout much of PNG and Solomon Islands), as the desire for new wealth proved irresistible. As usual, other economic straws were to be grasped at. Two villages had guest houses - a vain hope that tourism might one day emerge - but one at least had attracted official visitors, usually when they were stranded in Siwai (because of rain or absent transport).

Agricultural systems were returning towards the pre-crisis situation. Cocoa was being cleared of bush (but the most intermittent market, depending on rare ship visits, enabled only a few to profit from getting their dry beans over now rough tracks to the coast at Mamagota). Village markets had revived, but on a very small scale, partly because subsistence was now ubiquitously important - as wage employment had collapsed - and partly because cash was scarce. Gardens were faring poorly because of intensified pressures on the land (from both return migration and 
continued high population growth rates) and the ravages of a new insect pest, hence mounding was more common (Figure 8.3). Sago had become valuable again, where in the 1970s it was only an intermittent resource when hazard occurred (Connell and Hamnett 1978; Bourke and Betitis 2003) and had seemed on the verge of disappearance as a food.

Desire to participate again in the cash economy was universal. It continued to centre on cocoa, and new varieties were being introduced by UNDP and AusAID (Bourke and Betitis 2003: 92). New fermentaries had been introduced, including a

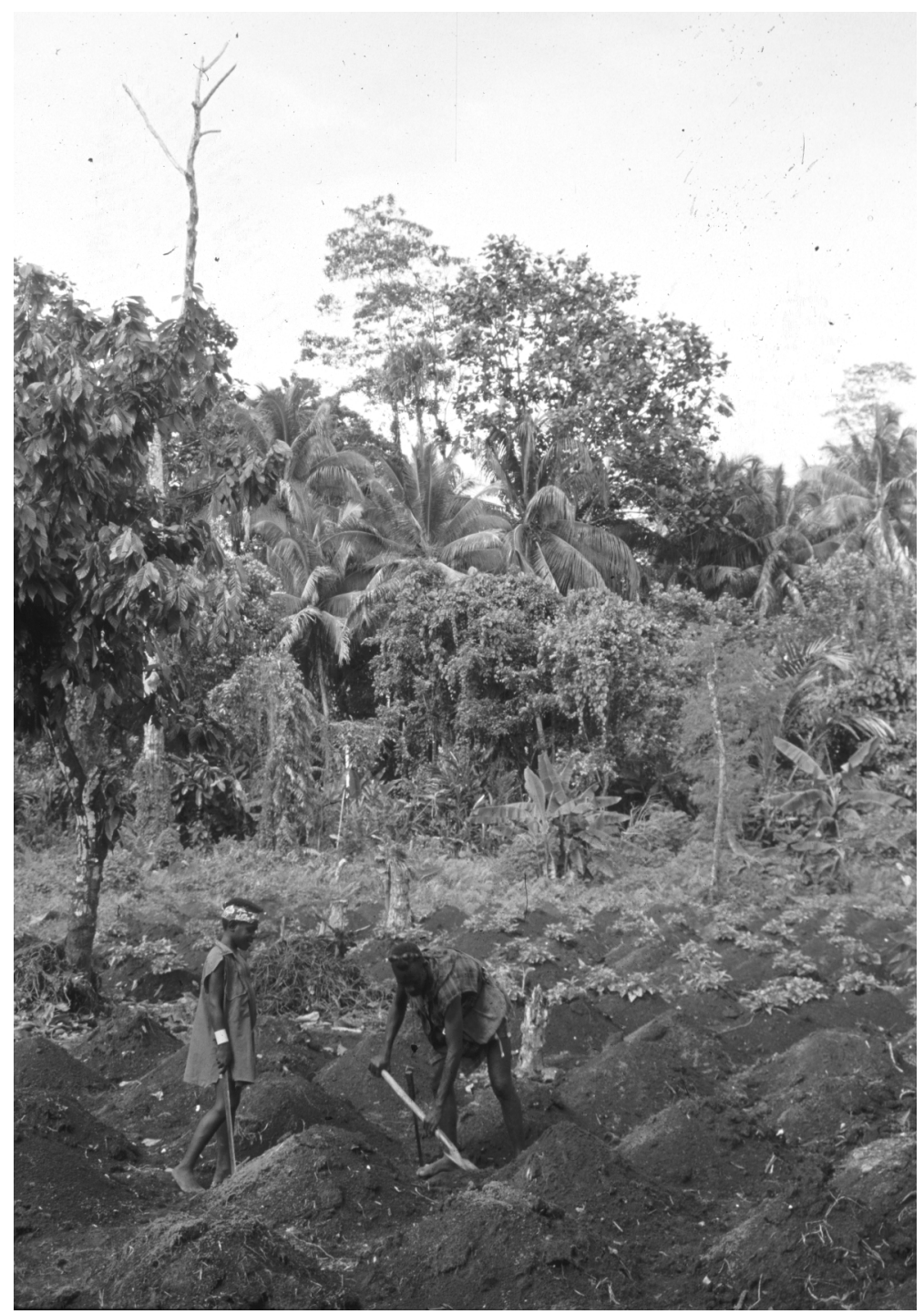

Figure 8.3 Mounding in a sweet potato garden, Siroi (2001). 
solar fermentary that proved largely useless in rainy Siwai, but despite the decline in production there was already a firewood shortage for local fermentaries. Indeed, firewood became a commodity for the first time in the 1990s. The long (and continuing) years without cocoa had created interest in new possibilities, notably low weight and high value chillies and vanilla (Figure 8.4), both of which have achieved recent success elsewhere in PNG, while external consultants continued to suggest new possibilities, such as rambutan (Bourke and Betitis 2003: 92), in some part because of concern over the future of cocoa. Chillies and vanilla were merely the last in a line of experiments, from cattle and crocodiles to fish ponds. Cocoa had always triumphed.

A few stores had been re-established, but even with little competition their turnover was small. Barely half a dozen vehicles ran on the roads; most of these were cannibalised from others (but some were donated church vehicles rather than those of individuals or village groups). Feeder roads were anxiously sought after, but there was no capital or equipment to reconstruct them (a costly and labourintensive process on unconsolidated soils under heavy rainfall). The transport system, and the collapse of cocoa, were the most visible indications that Siwai had effectively plunged back into the 1960s, but without the social order and anticipation that had then sustained the economy and society.

The old religions had declined and fractured. Where once the Catholic and the United Church held total sway (with a handful of Seventh Day Adventists in one village) in the 1970s, there was now diversity. The emergence of a charismatic movement - One Way - in the late 1970s had divided the United Church, but similar processes had continued and intensified. Pentecostalism had brought new

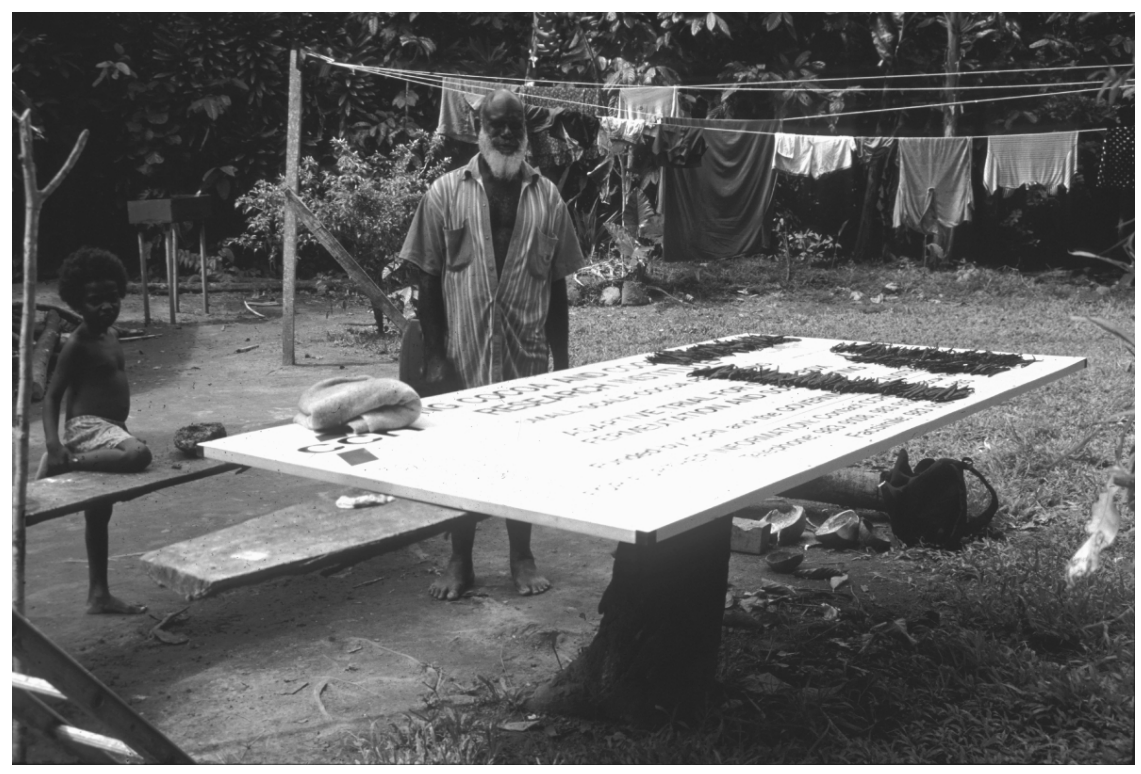

Figure 8.4 Vanilla drying on an appropriated AusAID signboard, Siroi (2001). 
churches, from the Wesleyan Methodist Church (which sought to return to a 'traditional' order) to the Gospel Lighthouse and the Christian Life Church, which sought to 'modernise'. In some cases the 'new' churches were lavishly funded from overseas, but their emergence correlated with the unparalleled uncertainties that the crisis engendered. They now attracted Catholics and they invariably brought new fundamentalisms, conflicts and tensions, even within households and villages, especially since charismatic religion offered new opportunities for leadership and the assertion of authority. Much as in Sepik, there was evidence that 'after a short, sharp and ecstatic frenzy of activity, people are left feeling depressed and let down' (Sowei and Allen 2003: 216). Sometimes linked to processes of religious change was the desire by, and practice of, many older men to write their own biographies, which tended to emphasise their own modernity as they had passed from 'darkness' into the 'light'.

Structures of leadership had changed. The young were less evidently in control, as they had been a decade earlier. The 'modern' skills of technology, literacy and numeracy had not helped Siwai during the crisis. Indeed, 'older' skills of coping in the bush had been validated. There had been some deliberate return to earlier structures of leadership, curiously validated not through any return to a bigman system - and the word mumi ('bigman') was as absent as it had ever been in recent decades - but by the invention of a chiefly system, a phenomenon evident elsewhere in Melanesia (e.g. Smith 2002: 151-53). The emergence of chiefs was a function of a need for local leadership (after old structures had collapsed, especially during the crisis) and for order after years of chaos. The new 'chiefs' were not however necessarily older men, rather those who were seen to be both knowledgeable in 'modern' ways but with clear respect for Siwai 'traditions' and who combined both authority and a sense of direction. (Ironically, chiefs were actually imposed on Siwai in the earliest days of the Australian colonial administration.) One particular new organisation, $\mathrm{RaMaPoHu}$ (whose name linked the four major 'Siwai tribes'), sought to combine 'traditional values' (especially those that related to land tenure) and reject the newest churches, to unite church, custom and state into a Great Council of Chiefs (which demanded the identification of all 'chiefs' and 'sub-chiefs' within Siwai), and to enable 'a rebirth of the natural leadership system'. Underlying this invention of tradition was a bid to ensure that land remained entirely in Siwai hands. Yet again, this offered new scope for leadership, and thus confusion.

Rescuing the past had become more common. As early as 1974 there had been a small 'museum', with the artefacts, such as grass skirts and stone axes, of earlier times. In 2001 a group of very elderly Siwais were engaged in a project to produce a Siwai dictionary in their desire to preserve the integrity of the language (daily traduced by Pidgin and English incursions and the neologisms of the young). As one eighty-year-old confided to me: 'we always trust in the oldest man [eighty-five years old] since only he really knows the proper language forms' (see also Harrison 2001: 6). The continued search for and veneration of Oliver's book was one more part of the search for an idealised past that was ever elusive.

In the 1970s, Siwai had almost completed the transition from an old order, 


\section{John Connell}

where bigman leadership was linked to tradition and heredity, to a new 'order', where leaders were elected and new knowledge gave them particular credence and authority. The difficulties of the 1970s, as Bougainville sought its own independence separate from that of PNG, had brought the first reversion to a more 'traditional' order in the establishment of more localised village councils in the place of local government councils (Connell 1977). Once again, after crisis, Siwai was turning to an imagined past for a new sense of direction.

Yet in the new era, however distant Siwai now was from wider regional and national political spheres, these remained sources of power, authority and especially resources. Like the people of Kairiru (Sepik) and elsewhere, 'local groups ... have found that creating a chief, whether from the whole cloth or from cultural precedent, is useful in the modern political arena' while simultaneously being a symbol of local and national culture and identity, strengthening these against the influence of distant institutions (Smith 2002: 153), as they sought to reinvent a traditional order that had already disintegrated.

\section{Conclusion: holding on?}

Few long-term studies of development exist in Melanesia and none deal with societies that have experienced such dramatic disruptions. What is unusual about Siwai (and other parts of Bougainville) is that seemingly inexorable processes of increased incorporation into the wider world (loosely globalisation) were utterly shattered and at least temporarily reversed, as local people became incidental victims of a particularly virulent and violent example of the 'resource curse'.

Even earlier, however, at the moment of greatest material success in the 1980s, problems had become apparent. A new capitalist order had been created, with villagers in thrall to the ramifications of global capitalism as a 'terminal peasantry' emerged. Yet cocoa, one of the more globally successful cash crops, had clear limitations, hence the constant concern - over more than forty years - with diversification. Declining crop yields and intensified pressure on land demanded increasingly intensive agricultural techniques. The kinds of structural changes that Brookfield demanded for Chimbu, in the New Guinea highlands, to prevent it becoming a 'dependent rural slum' (1973: 158), reached neither Chimbu nor Siwai. Land continued to provide security and certainty, but in a context of continued population growth and ecological degradation its strength was diminished. Growing pressure on land and the realisation that future populations would have limited access to good land were now at last widely acknowledged.

Evident on the land, where the social structure is firmly inscribed, the new world of choices and opportunities - even opportunism (Brown et al. 1990) - had destroyed the old order of certainty, security and stability. Greater flexibility also meant less social order, tensions over land tenure and inheritance and a diversity of opportunities for leadership, and so for conflict. Key leaders had been killed or had lost credibility during the crisis. Growing socio-economic differentiation emphasised new and sometimes entrenched inequalities: further individualism at the expense of cooperation. 
Siwai had come a very long way from the optimistic years of the late 1970s, when the boom years were in full swing and economic growth was no distant textbook condition. The collapse of the economy after a quarter of a century of success, at the same time as the onset of a decade of violence, had resulted in some degree of introspection over the nature of change and development. At the very least, change had not produced a 'glowing path of material improvement, social progress or global convergence' (Knauft 2002: 241).

Crucially, in an economic sense, little had really changed. Education and income remained central to perceptions of the good life, hence there could be no retreat from economic development. Siwais still sought the revival of cocoa, albeit with a renewed sense of the need for diversity, but were cautious over the prospects of reopening the mine (but were well aware that without the income and wages from the mine the prosperity of the past was unlikely to be regained). The quest for diversity was not so much a result of a concern for the loss of biodiversity, and there was limited Siwai interest in garden diversity, but a firm belief that some cash crop would hold the key to long-term success: a constant quest for the ultimate niche. For all its discontents, there could be no withdrawal from the quest for modernity.

Yet simultaneously, in a social and political sense, Siwai had turned back to the past. Order was increasingly assumed to rest on the apparent and very distant certainties of earlier times, which needed to be blended with the new. The persistent turn to 'custom', even through the invention of tradition, such as the quests for a dictionary and chiefs, marked the struggle for identity and worth in complex and fluctuating times. Siwai turned inwards and backwards to establish a social (and assumed historical) basis that might take them forwards. Siwais thus sought to combine a greater degree of cultural continuity with the impossibility of denying the necessity for economic development, hence not retreating from modernity. While few espoused the purity of $\mathrm{RaMaPoHu}$, excursions into capitalism could increasingly be seen as cautious essays in 'economic hybridity' that did not however contest or reject the renewed expansion of capitalism (other than of the copper mine), as elsewhere (Gegeo 1998; Yang 2000), but simply sought more subtle, complex and successful forms of accommodation with it.

Characteristically, Siwais sought both progress, in the sense of vanilla or guest houses, alongside charismatic religions, in terms of new ventures in the wider world, but they also attempted to preserve and conserve culture. Although the proponents of these different objectives were rarely the same people, their coexistence demonstrated the manner in which modernity embraced both opportunities to escape the constraints of kin and community and desires to 'remake and reawaken the autonomy of that community' (LiPuma 2000: 10). Put otherwise, in Siwai, as elsewhere, emphasis on locality and on globalisation did not bind together antithetical phenomena (ibid.: 299). Interplay between the local and the global was at the heart of the battle for a compatible modernity, and the desire to determine destiny.

At the same time, few had a clear sense of what constituted development; for themselves, Siwai or the nation - and even which nation they might be part of was still uncertain. Like Kragur villagers in Kairiru, East Sepik: 


\section{John Connell}

Many were plainly confused about the specifics of where they wanted to go and how to get there. Some degree of vagueness, confusion and inconsistency is part and parcel of culture. ... The rapid pace of change in Papua New Guinea in the twentieth century contributed a great deal to Kragur people's uncertainty.

(Smith 2002: 9-10)

Like others elsewhere in peripheral places, with uneven access to resources, whether intellectual or material, uncertainty reigned. People pursued 'culturally patterned but indeterminate goals' (Abu Hashish and Peterson 1999: 7). Aspirations varied between those with and without adequate land. Failed local businesses, and the collapse of the island economy, suggested that more than mere urban knowledge was required for success. The devastation that attended the decade of crisis, but more importantly the ideological search for a form of development that combined the local and the global, refuted any simple notions of linear change. Indeed 'modernity is a condition of having contradictory ideologies that can never be completely fulfilled' (Brison 2003: 347).

My own role had changed over time and had also become more complex. No longer was I merely a source of information about more distant worlds, but in more difficult times I had become a potential conduit to those worlds, and a possible means of acquiring the goods that were now so difficult to obtain. (I returned to Australia with requests for everything from karate suits to bibles, from seeds to schoolbooks). All this was part of a new diversity of desire that emphasised the lack of homogeneity of experience and aspiration within Siwai, and the range of idiosyncrasies that contributed to the contradictory characteristics of modernity (Gewertz and Errington 2004). As important as my potential market access, especially after it had been ascertained that I too had written a book (which resulted in questions about its availability, content and profitability), was my perceived ability to document local lives. I was frequently requested to record stories of every kind, but particularly those of the past (sometimes a quite recent past), which people saw as almost literally fading before their eyes. Towards the end of the last stay I took a long walk with a particularly garrulous man; the conversation traversed the state of the roads, the problems of political reconciliation, the new cocoa fermentaries and much more, before it eventually focused on the eventual outcome of the New South Wales v. Queensland State of Origin rugby league match - due to be broadcast from Sydney in a couple of days time. Maybe it was only the last topic in a particularly long conversation, and perhaps it was just a distraction from significant and challenging local concerns, but it was a measure of the gradual shift to normalcy and one final reminder that Siwai, and Bougainville, perhaps prosaically, were tied into the workings of a much larger if still inaccessible and unpredictable outside world.

\section{Notes}

1 The bulk of this work was undertaken in the two villages of Siroi in Korikunu and Maisua 
in Rataiku - geographically distinct as lowland and upland villages respectively, the first being primarily a Catholic village and the second a Uniting Church village. I am much indebted to enormous numbers of people, but particularly Anthony Anugu, John Sune and Stephen Sukina. I would like to thank Douglas Oliver, Mike Hamnett and Gene Ogan for their comments on an earlier version of the chapter.

2 On two quite separate occasions I was asked to let the Siwai people know when Douglas Oliver died since they claimed to have no famous people of their own and would like to turn that particular date into a Siwai public holiday. Almost ninety and in peaceful retirement, Oliver might have had a wry perspective on that. No one has yet suggested that my own death might be similarly commemorated!

\section{References}

Abu Hashish, S and Peterson, M (1999) Computer Khatbas: Databases and Marital Entrepreneurship in Modern Cairo, Anthropology Today, 15 (6), 7-11.

Bourke, M and Betitis, T (2003) Sustainability of Agriculture in Bougainville Province, , Canberra: Land Management Group, Department of Human Geography, Australian National University.

Brison, K (2003) Imaging Modernity in Rural Fiji, Ethnology, 42, 335-48.

Brookfield, H (1962) Local Study and Comparative Method: An Example from Central New Guinea, Annals of the Association of American Geographers, 52, 242-54.

- (1968) The Money that Grows on Trees, Australian Geographical Studies, 6, 97-119.

(1973) Full Circle in Chimbu, in H Brookfield (ed.), The Pacific in Transition, London: Arnold, pp. 127-62.

Brown, P, Brookfield, H and Grau, R (1990) Land Tenure and Transfer in Chimbu, Papua New Guinea: 1958-84. A Study in Continuity and Change, Accommodation and Opportunism, Human Ecology, 18, 21-49.

Connell, J (1973) The Geography of Development or the Development of Geography, Antipode, 5 (2), 2-39.

-(1976) Bougainville is Legitimate Again, Geographical Magazine, 48, August, 651-54.

-(1977) Local Government Councils and the Establishment of Village Government, in J Connell (ed.), Local Government Councils in Bougainville, Bougainville Special Publication No. 3, Christchurch: Department of Geography, University of Canterbury, pp. 132-74. (1978a) The Death of Taro. Local Response to a Change of Subsistence Crops in the Northern Solomon Islands, Mankind, 11(4), 445-52.

-(1978b) Taim Bilong Mani. The Evolution of Agriculture in a Solomon Island Society, Development Studies Centre Monograph No. 12, Canberra: Australian National University.

- (1988) Temporary Townsfolk? Siwai Migrants in Urban Papua New Guinea, Pacific Studies, 11, 77-100.

- (1991) Compensation and Conflict: The Bougainville Copper Mine, Papua New Guinea, in J Connell and R Howitt (eds), Mining and Indigenous Peoples in Australasia, Melbourne: Oxford University Press, pp. 54-75.

(1997) Papua New Guinea. The Struggle for Development, London: Routledge.

Connell, J and Hamnett, M (1978) Famine or Feast: Sago Production in Bougainville, Fournal of the Polynesian Society, 87, 231-41.

Gegeo, D (1998) Indigenous Knowledge and Empowerment: Rural Development Examined from Within, The Contemporary Pacific, 10, 289-316.

Gewertz, D and Errington, F (1991) Twisted Histories, Altered Contexts: Representing the Chambri in a World System, Cambridge: Cambridge University Press. 


\section{John Connell}

Gewertz, D and Errington, K (2004) Toward an Ethnographically Grounded Study of Modernity in Papua New Guinea, in V Lockwood (ed.), Globalization and Culture Change in the Pacific Islands, Upper Saddle River: Pearson, pp. 273-84.

Hamnett, M and Connell, J (1981) Diagnosis and Cure: The Resort to Traditional and Modern Medical Practitioners in the North Solomons, Papua New Guinea, Social Science and Medicine, 15B, 489-98.

Harrison, S J (2001) The Past Altered by the Present. A Melanesian Village after Twenty Years, Anthropology Today, 17 (5), 3-9.

Hobsbawm, E (1983) Introduction: Inventing Traditions, in E Hobsbawm and T Ranger (eds), The Invention of Tradition, Cambridge: Cambridge University Press, pp. 1-14.

Howlett, D (1973) Terminal Development: From Tribalism to Peasantry, in H Brookfield (ed.), The Pacific in Transition, London: Arnold, pp. 249-73.

Knauft, B (2002) Exchanging the Past. A Rainforest World of Before and After, Chicago, IL: University of Chicago Press.

LiPuma, E (2000) Encompassing Others. The Magic of Modernity in Melanesia, Ann Arbor, MI: University of Michigan Press.

Mitchell, D (1982) Frozen Assets in Nagovisi, Oceania, 53, 56-66.

Nash, J (2005) Nagovisi Then and Now, in A Regan and H Griffin (eds), Bougainville Before the Conflict, Canberra: Pandanus, pp. 400-409.

Oliver, D (1955) A Solomon Island Society: Kinship and Leadership Among the Siuai of Bougainville, Cambridge, MA: Harvard University Press.

Read, K (1986) Return to the High Valley. Coming Full Circle, Berkeley, CA: University of California Press.

Regan, A (1998) Causes and Course of the Bougainville Conflict, Fournal of Pacific History, 33 , 269-85.

Sahlins, M (2005) The Economics of Develop-man in the Pacific, in J Robbins and H Wardlow (eds), The Making of Global and Local Modernities in Melanesia, Aldershot: Ashgate, pp. 23-42.

Smith, M F (2002) Village on the Edge. Changing Times in Papua New Guinea, Honolulu, HI: University of Hawaii Press.

Sowei, J and Allen, B (2003) Papua New Guinea, in H Brookfield, H Parsons and M Brookfield (eds), Agrodiversity. Learning From Farmers Across the World, Tokyo: United Nations University Press, pp. 212-31.

Yang, M M (2000) Putting Global Capitalism in Its Place. Economic Hybridity, Bataille and Ritual Expenditure, Current Anthropology, 41, 477-510. 


\title{
9 Oil palm expansion in Sarawak Lessons learned by a latecomer?
}

\author{
Niels Fold and Tina Svan Hansen
}

Malaysia has dominated the world market for oil palm since the early 1970s. Cultivation of oil palms, and processing and production of the final product, was primarily located on the Malay Peninsula up to the late 1980s. By then land had become scarce and the development of resettlement schemes and private plantations in the Peninsula stagnated but it had expanded in other regions of Malaysia. Due to the construction of vast plantation areas by the major resettlement parastatal and private companies, the area under oil palms in Sabah, one of the two Malaysian states on Borneo, expanded rapidly in the late 1980s and early 1990s (Sutton 2001). During the mid-1990s, oil palm cultivation started to take off in the other Borneo state, Sarawak.

This chapter traces the effects of the expansion of oil palm cultivation in Sarawak, and examines whether the experience gained from about twenty years of oil palm cultivation and palm oil production on a world scale has been transferred to handle the particular technical, organisational, environmental, political and economic challenges in Sarawak. If not, what were the reasons for the lack of transferability of knowledge from one region to another within the same country?

The chapter initially reviews Brookfield's explanation of the factors behind industrial transformation in the Malay Peninsula, and especially the complex reasons for the changes in land use that were linked to the expansion of the 'resource frontier' - the other facet of the industrialisation process, in which primary rain forests were transformed into perennial crop land. This transformation took place in phases linked to world markets, when one or a set of commodities took up a dominating position. This process is then compared with the ongoing transformation of Sarawak's forest areas to oil palm plantations. A recent case study of the Niah catchment area substantiates the present (localised) position of the 'frontier' and how it affects the land use of local communities.

The aim is to track down the socio-economic and political driving factors, and effects, of the oil palm expansionary process, and to explain similarities and divergences between the two regions in Malaysia in terms of the competitive industrialisation and staple trap models, which conceptualise the growth and development paths for resource-poor and resource-abundant economies, respectively (Auty 2001). A resource-abundant economy is considered to engender a factional and predatory state that distorts the economy in the pursuit of rents - often designated 
as 'the natural resource curse' - whereas a number of conditions promote a developmental state in the resource-poor economy. The dichotomy has previously been used for intercountry comparisons of socio-economic growth processes, but we suggest that it can also be used for intracountry comparisons.

\section{Resource frontier expansion and land use transformation in Peninsular Malaysia}

The best way to conceptualise Brookfield's model of the transformation process in Peninsular Malaysia is to use his idea of the 'resource frontier strategy' (Brookfield 1994a-d; Brookfield et al. 1990). The model takes as its point of departure the comprehensive spatial expansion of agricultural land at the expense of primary rainforest. Frontier expansion is closely related to changes in the world market for commodities - coffee, tin, rubber, timber and palm oil in the case of Malaysia - and the frontier moves with variable speed, depending on the prevailing conditions on the world market. At particular times, global demand for new commodities will accelerate the frontier's expansion. At other times the appearance of substitutes, new consumption patterns or new markets result in a stagnating or declining demand, causing the frontier's spatial extension and form to be relatively stable, otherwise a new commodity takes over the same functional role. Usually, state policies stimulate or hold back frontier expansion: some, notably protective environmental legislation, discourage the expansion.

Three major phases in the expansion of the resource frontier in Malaysia can be identified. The first phase began in the early colonial period, when Chinese traders and farmers cleared coastal land for export cultivation of cassava and sugar. Later in that phase, European settlers expanded the cultivated area and took over part of the cleared land for coffee. Rich alluvial tin deposits in the western Peninsula attracted Chinese traders and later British mining companies. Tin mining activities resulted in the establishment of local urban agglomerations and a rail and road infrastructure that linked mines in Perak and Selangor with smelters in the harbours of Prai and Singapore. An emerging road system made up the more fine-meshed transportation system, acting as feeder roads to new railway lines (Brookfield 1994a). This relatively sophisticated colonial transportation system was a decisive factor in the rapid establishment of the mainly British owned rubber plantations in the early part of the twentieth century.

In the second phase of the advancing resource frontier, previous coffee plantations were replanted and virgin land was cleared on an unprecedented scale and planted with rubber. Malay smallholders and Chinese small farmers also started to cultivate rubber in a less capital-intensive way and their share of total production increased substantially. The rubber boom and the mutual expansion of plantation agriculture came to a halt with the worldwide depression during the interwar period, and rural transformation slowed (Overton 1994). Increasing demand for rubber due to the post-war industrial growth of Western Europe and the United States brought a resumed expansion of the frontier, although this was somewhat slowed in the early 1960s by the appearance on the world market of petroleum- 
based synthetic rubber. By then, however, oil palms had been planted for some years on both former rubber plantations and virgin land, as part of state-initiated efforts to diversify agricultural production.

In the third and final phase, through the 1970s and 1980s, rural areas were rapidly transformed due to the tremendous expansion of oil palm plantations. The main objectives of the New Economic Policy, enacted in 1970 after ethnic riots in 1969, were to eradicate rural and urban poverty and reduce socio-economic differences between ethnic groups. Two mechanisms to fulfil these objectives were stimulating export-oriented, labour-intensive industrialisation and boosting resettlement schemes by targeting landless and low-skilled Malays. This group was offered new opportunities to improve their material status by working on plantations and living in newly established towns, eventually taking over the plantation land attached to the specific scheme. Substantial forest and swamp areas were cleared and transformed into resettlement schemes through the main parastatal, the Federal Land Development Agency (FELDA). Other state institutions were established to foster increased income through production of cash crops in existing village communities by offering extension and logistical services in relation to so-called in situ schemes (Hadi 1994).

Early in this final phase, clearance was primarily in the forest fringes of the southern and western Peninsula, while more peripheral areas in the east and north were cleared much later. The pattern of clearance changed from a general deforestation to a more area selective pattern, particularly linked to FELDA's vast regional development programmes in the eastern Peninsular. Almost all the land so transformed in Peninsular Malaysia was legally 'unused' state land, so relatively few Malay farmers were affected. However, the conversion of forests resulted in displacement of an unknown number of indigenous people, who had previously used the land without formal titles. Some of these indigenous groups were resettled, but their access to natural resources was severely constrained (Brookfield 1994b, 1994c).

In this expansion, the oil palm area of Peninsular Malaysia doubled from about 600,000 hectares in the mid-1970s to $1,300,000$ hectares in the mid-1980s and further increased to about 1,700,000 in 1990 (see Figure 9.1). Frontier expansion then slowed, but by 2000 the total planted area was about 2,000,000 hectares (MPOB 2003). This significant slowing of (agricultural) resource frontier expansion in the Peninsula towards the end of the century was linked to land (and labour) scarcity, combined with low commodity prices on the world market and decreasing federal state revenue. Comprehensive state involvement in many agricultural activities, notably the expansion of the resettlement programme, was considerably scaled down. In 1991, FELDA's expansion stopped and the organisational structure changed (Fold 2000). Subsequently, the oil palm area has mainly been expanded within in situ schemes including former rubber land, and by private plantations in Borneo.

Frontier expansion in the Peninsula had various consequences that can be compared with the later oil palm based frontier expansion in Sarawak. First, the total rice area remained more or less constant during the final part of the third 


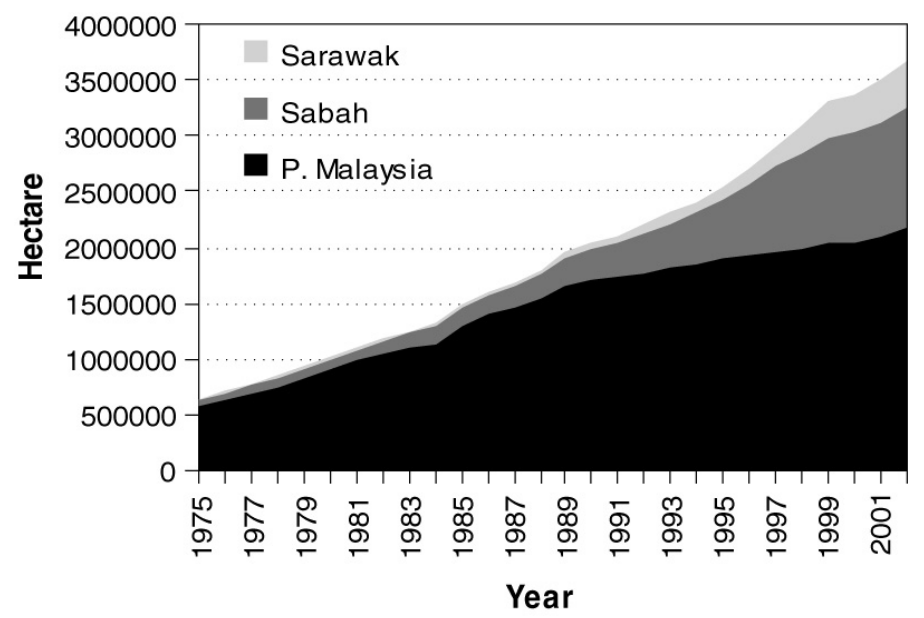

Figure 9.1 Total land area under oil palm, Malaysia.

phase, but regional differentiation occurred, with expansion of the areas in the northwestern part of the Peninsula and decreasing areas in the southwestern area. Regional differences were caused by polarisation between irrigated and nonirrigated areas and were reflected in a significant drop of employment, as mechanisation was far more comprehensive in what came to be the dominant rice bowl of the northwest (Brookfield 1994b).

Second, in the rice producing areas, married women became increasingly important in the rural labour force. In combination with population growth in the plantation areas, primarily of children of the settlers and workers in private plantations, a surplus of labour was created during the 1960s and 1970s, resulting in a considerable flow of migrants to towns. Husbands and younger people, particularly young girls, left for urban employment opportunities, leading to a 'remittance family economy' (Brookfield 1994b). Social differentiation increased within the rice growing areas, as some farmers were more resourceful and better able to exploit the new possibilities than others.

Third, the resultant comparative advantage of cheap, relatively skilled and compliant labour was the basis for successful implementation of the export industrialisation strategy embedded in the New Economic Policy (NEP). The specifics of Malaysia's colonial past, the organisational capability and work discipline linked to plantation agriculture and large-scale mining all played a decisive role in the industrialisation process during the 1970s and early 1980s (Overton 1994). From this perspective it is surprising that agro-based industries had not been seriously promoted before the mid-1980s, when development strategies for priority agro-industries and products were elaborated in the Industrial Mid-term Plan, mainly centred on rubber and palm oil but also including timber.

Fourth, the strong incentive for rural-urban migration gradually resulted in a rural labour shortage, particularly in the resettlement schemes and export crop 
plantations and also in the food producing sectors. Labour saving technology was introduced where it was available and adaptable, while primarily Indonesian migrants, many illegal, filled the remaining gap. The increasing shortage of rural labour also affected the most recent FELDA schemes, with about 100 plantation schemes being cultivated by Indonesian migrants in the mid-1990s. The latest frontier expansion by FELDA in the Peninsula, and also in Sabah, had in effect acted as an extension of the Indonesian transmigrasi programme (Brookfield 1994c; Sutton 2001).

Rural-urban migration far surpassed the counter-directional flows of labour, even as FELDA activities spread to previously deserted areas. Initially, labour was employed in the main areas of forest conversion, and settlers and their families later lived in newly established growth centres in the regional schemes. Various manufacturing industries gradually followed, primarily companies in the woodworking sector and in processing (milling) of palm oil. However, the expected surge in the inflow of people employed in other manufacturing industries or the service sector never materialised.

Fifth, due to the easy access to raw materials, a substantial wood processing industry was established in areas where deforestation was especially comprehensive. Apart from resulting in much waste of resources, due to inappropriate felling practices, badly coordinated felling also led to regional supply problems in the wood processing industries as timber became exhausted. Some of the factories in the western Peninsula started to source timber from the eastern part and during the late 1980s and early 1990s much of the timber had to be brought from the two Borneo states (Brookfield 1994c).

Sixth, the scale and speed of the frontier expansion resulted in many environmental problems, as the environment was used both as a resource for exploitation and a sink for waste. Mechanisation of logging activities, through the use of chain saws, crawler tractors, heavy road vehicles and bulldozers for road construction, destroyed vast areas of vegetation and reduced soil productivity through compaction and heavy erosion. Moreover, the new tree crops offered less protection against erosion caused by rainfall and there was reduced nutrient recycling due to the change in land cover. Changes in the hydrological regime due to plantation agriculture also resulted in severe problems with flooding and periodic water shortages. Agricultural and agro-industrial activities polluted rivers to an extent that eroded the material basis for fishing communities. Even though the situation has changed considerably since the 1980s, untreated effluents from palm oil mills and rubber factories have taken their toll, not only in rivers but also sometimes also in the rice fields. Finally, the use of chemical fertilizers, pesticides and insecticides contributed to the destruction of water resources (Brookfield 1994d).

\section{From forests to plantations: dynamics of oil palm expansion in Sarawak}

When the pace of rural transformation through oil palm planting slowed in Peninsular Malaysia, Sabah gradually became the dynamic frontier region. The 
planted area expanded from about 100,000 hectares in the early 1980s to about 300,000 in the early 1990 s, and then accelerated to reach 1,000,000 hectares less than a decade later in 2000. The development of Sarawak's oil palm areas became a 'third wave', after Peninsular Malaysia and Sabah (see Figure 9.1). The planted area started expanding during the late 1990s and was a little more than 400,000 hectares in 2002, corresponding to about 3 per cent of the total Sarawak area in 2002. Consequently, Sarawak's production of crude palm oil (CPO) rose by more than 33 per cent, from about 220,000 tonnes to about 740,000 tonnes (Department of Agriculture, n.d.), increasing its share to some 6 per cent of total Malaysian CPO production.

Even though Sarawak's palm oil production is still dwarfed by that of the other regions, the expansion is significant and reflects its increasing importance in the state government's development strategy. Sarawak aims to be 'fully developed' by the year 2020, and the state government has realised the need to find another economic base besides oil, gas and timber. Timber resources were starting to run out as Sarawak entered the 'post logging era' (Majid Cooke 2002) following the boom from the mid-1970s to the early 1990s. During that period, the strong and prolonged demand for tropical hardwood in East Asia JJapan, South Korea and Taiwan) initiated the timber boom in Sarawak after more accessible timber in Sabah (and other Southeast Asian countries) was effectively exhausted. After 1970, logging concessions were used by the two dominant Chief Ministers to stabilise their own, and their ruling parties', political power (Ross 2001). A complex patronclient network became established between the ruling fraction of the elite and the timber companies, primarily owned by ethnic Chinese, the latter financing electoral and other campaigns.

As late as 1998, state revenue in Sarawak relied heavily on the forestry sector (52 per cent) while the oil and gas sector contributed some 17 per cent. Since the early 1970 s, when the rights were surrendered to the federal government, the revenue from oil and gas has been limited to 5 per cent of the gross value of on-shore and off-shore production (Leigh 2001); state revenue was raised in 1998 by introducing a sales tax of 5 per cent on CPO. Sabah also profits on palm oil production by a fixed levy on CPO, but none of the states in the Peninsula have similar duties (Omar et al. 2001). Oil palm is now the most important commercial crop, and the area under oil palm production had surpassed the area under rice production (the staple food crop) by 1996 (Figure 9.2). The rice area has been remarkably stable during the past three decades, suggesting a similar polarisation to that in Peninsular Malaysia, between efficient and degrading rice producing regions. In contrast, the state government aims to reach one million hectares (about 8 per cent of total area) under oil palms in Sarawak by the year 2010 (Ministry of Rural and Land Development 2003). Most of the land has already been identified and allocated by Sarawak's Land and Survey Department. The geographical concentration of the oil palm area is considerable as the majority of the plantations will be located in the relatively flat coastal zone.

In Sarawak, the majority of land belongs to the state (a notable exception being Native Customary Rights Land) and allocation of state land is within the jurisdiction 


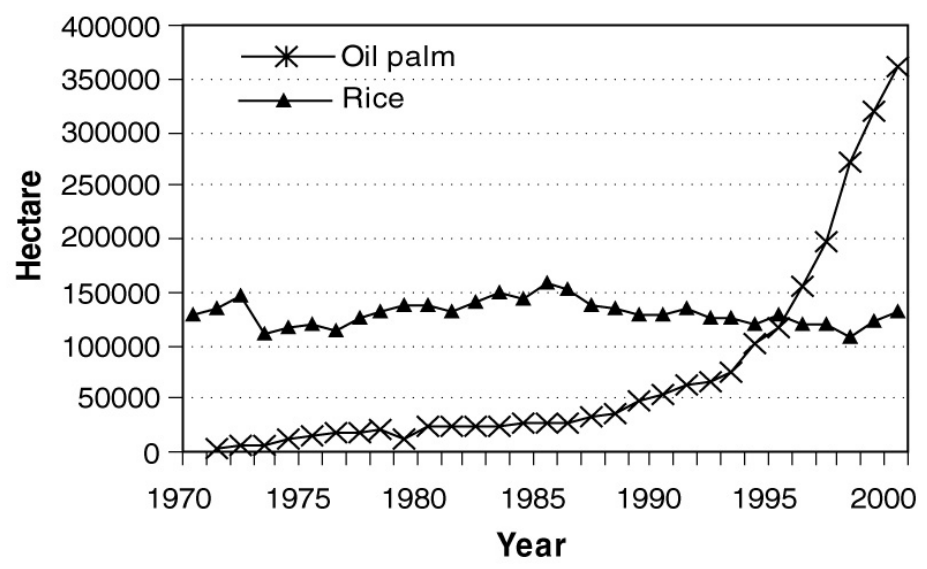

Figure 9.2 Land areas under oil palm and rice production, Malaysia.

of the State Planning Authority (SPA) under the Chief Minister's Office. The importance of oil palm production for economic growth is reflected in the fact that agricultural plantations have recently been classified as a public good, implying that the SPA can expropriate land for oil palm plantations. This dramatic initiative reflects the fact that land issues and disputes over titles have become a crucial barrier for the further expansion of the resource frontier in Sarawak, primarily because of the greater awareness of indigenous people's rights and of environmental threats. The issue is further complicated by ambiguous official categories of different types of land, which results in particular interpretations by different dominant vested interests.

The present land classification system in Sarawak is basically the Land Code issued by the colonial government in 1958. Land is divided into five categories, some of which are further subdivided (Cramb and Dixon 1988; Kaur 1998). Reserve Land is held by the state government and is mainly Permanent Forest Estates, which again are divided in a number of subcategories (including Protected Forest Land) depending on variations in the scope of restrictions on entry and exploitation of resources by the indigenous population. For instance, so-called Forest Reserve is mostly productive forest that can be logged, provided a license is issued by the relevant state authority. In addition, hunting and collection of non-timber forest products by the local population are allowed, provided that permission from the authorities has been obtained (Kaur 1998). In totally protected areas, such as National Parks, logging is not allowed.

Only individuals who are legally defined as indigenous persons can acquire title to the land designated Native Area Land, which is primarily located in the coastal area and characterised by shifting cultivation and small-scale agriculture. The Mixed Zone Land is mostly near urban centres and is used for numerous purposes as no restrictions on ownership apply.

The Interior Area Land, the largest classification, is primarily located in the 
eastern interior. It is characterised by forests, and there is free access for the indigenous population to collect non-timber products. An important subcategory is the so-called Native Customary Land, which is not held under title but is subject to native customary rights. Hence, the land is officially referred to as Native Customary Rights (NCR) Land. This type of land is not surveyed, but recent official estimates claim that it constitutes 13 per cent of total area in Sarawak, even though representatives from the same state institution previously had estimated the share as high as 25 per cent of the state (see Ngidang (2002) for details). Interior Area Land and NCR Land is not surveyed systematically and the territorial extension and limits are therefore often subject to contradictory claims from shifting cultivators and private companies, respectively.

The private sector is mostly backed by the state in land disputes since land is allocated to the companies by the state. Although the Land Code of 1958 acknowledges the rights of indigenous groups to live off their land, it does not fully recognise their ownership of the land except for land occupied as customary land before 1958 (Majid Cooke 2002). Hence, many communities are presently facing problems in providing evidence of their presence before 1958, since they were unaware of official regulations that required them to apply and obtain formal permission to expand their territory or occupy new uncultivated areas. They simply migrated to new areas and claimed customary rights according to adat (Cleary and Eaton 1996). These communities are now officially 'illegal squatters' on state land. They are particularly threatened by the new development of oil palm plantations as it is extremely difficult for them to get any formal title to land they have previously used.

Oil palm production in Sarawak is carried out mainly by three different types of companies: private companies, state and federal parastatals (FELDA and the Federal Land Consolidation and Rehabilitation Authority [FELCRA]) and socalled NGR joint venture companies (NCR-JVCs). The relevant Sarawak state parastatals are the Sarawak Land Development Board (SLDB), the Land Custody and Development Authority (LCDA) and the Sarawak Land Consolidation and Rehabilitation Authority (SALCRA). Local timber companies own many of the private plantations and are located in the core Sibu-Bintulu-Miri region of the northern part of Sarawak (Figure 9.3), where large-scale oil palm production in Sarawak started. Oil palm cultivation was not part of the initial business activities of the Sarawak timber companies. There was no need for them or local contractors to invest in the less profitable oil palm cultivation as it was relatively easy to expand their logging concessions. Moreover, the unstable political climate and the volatility of business conditions in which logging activities took place provided no incentive for any long-term involvement that implied substantial sunk costs. Only later when easily accessible forest resources, primarily in swamp areas, became scarce did companies start to incorporate oil palm cultivation into their strategies and diversify their business interests. However, the main incentive to enter the oil palm business was probably the right to clear-fell the forest before the establishment of a plantation. Part of the profit was then used as the initial investment to establish the plantation. 


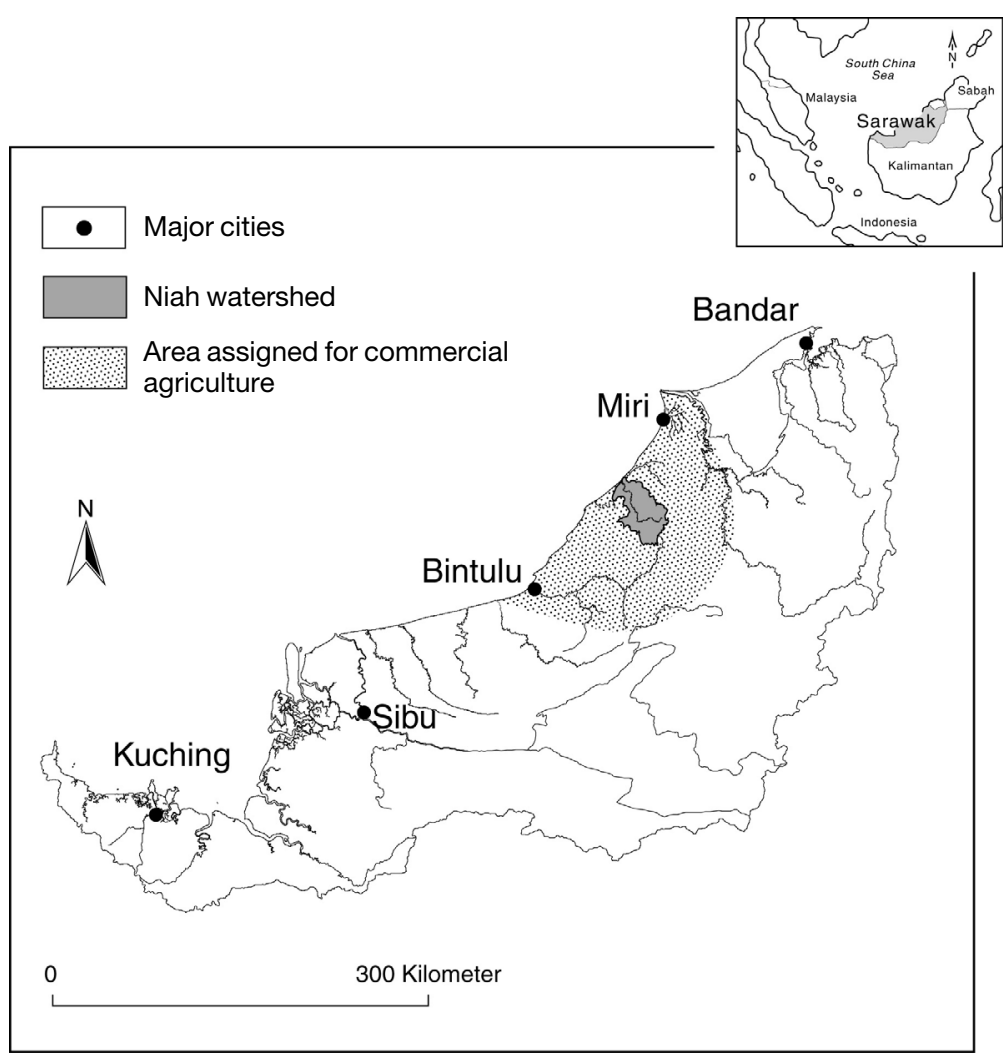

Figure 9.3 Sarawak.

Privately owned plantations are primarily established on former Interior Area Land and Protected Forest Land that has now been converted into Mixed Zone Land. Contrary to the situation in Sabah, local business interests own most of the oil palm plantations in Sarawak. This suggests the existence of a 'space of autonomy' for local private accumulation and political parties as opposed to the dominating presence of companies and ethnically based parties operating in Peninsular Malaysia (Leigh 2001).

Most plantations controlled by parastatals are in the southern and more densely populated parts of the state (Kuching and Sri Aman Divisions). These plantations were mostly developed by SALCRA on Native Area Land, where existing communities were assisted to start commercial crop plantations (rubber, pepper, cocoa or oil palm) while maintaining some degree of subsistence farming. These in situ schemes were quite popular among the indigenous population as a number of development projects for the community dwellers were tied into the agricultural activity (infrastructure, health and education). However, the commercial activities generally failed. The schemes were too costly for the parastatals, and the state government has stopped this kind of parastatal activity. In Sarawak, the 
FELDA-like resettlement schemes are insignificant; those that do exist are linked to the construction of a hydroelectric scheme (the Batang Ai dam) and political tensions related to border controversies (Lemanak).

SLDB and LCDA are instead involved in a new organisational venture. In the mid-1990s the Sarawak government launched the concept of the NCR-JVCs, based on the construction of a joint venture company comprising a private plantation company, a number of local communities or longhouses and one of the parastatals, the latter acting as a trustee on behalf of the communities and monitoring the operations of the private company. The aim was that local communities participated in the project by handing over their NCR Land as one coherent parcel of more than 5,000 hectares to the trustee, who would then lease out the land to the joint venture company. The private company controls 60 per cent of the equity and the communities hold 30 per cent in common and the parastatal the remaining 10 per cent of the shares. The land is leased for 60 years, corresponding to two oil palm crop cycles, after which the communities can decide whether they want titles to the land or continue the plantation activity (Ministry of Land Development 1997).

The official objective is to increase material wealth for the land-rich but cashpoor indigenous population, so integrating them into commercial agriculture by using 'idle' land. In addition, the state government wants to stop shifting cultivation, which is officially perceived as primitive and environmentally unfriendly due to the practice of open burning of forests. However, various observers consider the NCR-JVG concept as a way to alienate more land for private oil palm plantation companies, since the attention of the state government and the private companies turned to 'unused' NGR land when the major part of the most suitable land resources became scarce in the mid-1990s (Ngidang 2002; Leigh 2001; Majid Cooke 2002).

The new concept is also contested by many groups among the indigenous population, who doubt that they will benefit from the project or that their heirs will be able to get titles to the land after 60 years. However, a significant feature of the internal debate among the Ibans - the largest indigenous group of longhouse dwellers primarily located in the areas designated for commercial agriculture - has been an emerging fragmentation of social cohesion within particular longhouses. This is caused by tensions created by the clash between the traditional land tenure systems and the formal requirements of the NCR-JVC concept.

Iban longhouse communities occupy a distinct territory (menoa), in which each household (bilek) is the basic right-holding unit (Cramb and Wills 1990). Although the traditional land tenure system is community based, in the sense that property rights are assigned and enforced at community level, most property rights are held at the household level. An individual household's right to land is gained by its membership in the longhouse community. Traditionally, when a bilek left the longhouse community to settle in another area they lost their rights to the land and the trees (Freeman 1992). The rights involve general access to the menoa and the right to clear primary forest for cultivation. During the cultivation period, households have exclusive rights to the plot and retain these rights in subsequent years as long as they are members of the longhouse community. Households can claim rights to trees 
they first harvested, utilised or planted. Land can be borrowed among households, but it is never sold and is rarely leased. Often, a small part of the menoa is held as community forest with equal right or open access for all members of the longhouse community. Despite the high degree of individual rights in Iban land tenure systems there is remarkable cooperative behaviour in the communities. According to Cramb and Wills (1990) this is reflected in the relatively small number of disputes within longhouse communities compared with more frequent disputes between them.

However, the balance between individual rights and cooperative behaviour in the longhouses in terms of rights and access to land is seriously disturbed when land is converted into an NCR-JVG. Because of the many small plots belonging to each household and the capacity constraints of the Land and Survey Department, only the perimeter of the menoa is surveyed. Each household must agree on its individual share of the total land. This share determines both the amount of money they will receive from the joint venture company for the next 60 years and the size of the land on which they can claim title to after 60 years, hence the issue is very sensitive. Many households do not feel that they are fairly treated and so negotiations create many conflicts and bad feelings in the longhouse communities. In the next section, these frictions and accommodations of the frontier expansion processes are examined in a particular catchment area in Miri District.

\section{Resource frontier dynamics in the Niah catchment area}

The Niah catchment area is located in Miri District (Figure 9.3). The first largescale oil palm plantations were established in the district in the early 1970 s but production did not expand substantially before the 1980s, when the forest resources were exploited on a large scale. Miri District was assigned for commercial agricultural development at an early stage because of the relatively low population density and its location in the coastal zone. Despite the district only occupying approximately 4 per cent of Sarawak's land area, it includes roughly 20 per cent of the allocated oil palm area in Sarawak. Thus approximately 45 per cent of the land area in Miri District (about 195,000 hectares) was allocated for oil palm plantations in 2002. Oil palm plantations are primarily concentrated in the southeastern part of the district, particularly about 40-50 kilometres from the sea and in a narrow belt along the district's coastline. In practice, the oil palm plantations in the southern part of Miri District make up the northern fringe of a vast, more or less coherent, area of oil palm plantations that comprises about 50 per cent of the total oil palm area in Sarawak.

The Niah catchment area, about 1,300 square kilometres, is in the coastal zone between Bintulu and Miri and makes up the border area of the vast Sarawak oil palm region. Large-scale land cover and land use changes have taken place in the catchment area in recent decades following the area's assignment to oil palm cultivation by the state government. The ethnic composition of the population has become very diverse; the majority of the approximately 15,000 people are Iban, followed by Chinese, Malay, Penan, Indonesian and others. Most live in the 
northern part of the catchment area, and an unknown number of migrant workers, mainly from Indonesia, work and live in the oil palm plantations in the south. The land use systems in Niah catchment can broadly be divided into two categories (see Figure 9.4): large-scale logging and oil palm plantations owned by commercial enterprises; and small-scale farming systems characterised by shifting cultivation and vegetable production.

Extensive forest areas were logged and gradually replaced by oil palm plantations; although the first oil palm plantation was established in 1976, the area under oil palm only started to increase rapidly in the 1990s. State institutions established the first plantations in the central and northern parts of the catchment area, while private companies focused their investments in exploiting the more profitable forest resources in the southern part during the 1970s and first half of the 1980s. In the late 1980s and the 1990s, private companies converted huge areas into oil palm plantations (Hansen 2003). One such company was Bintulu Lumber, which had previously only engaged in logging activities. After the first round of logging in the 1970s the company left the concessions for regeneration, and in the 1980s, when forest resources became scarce, it started to diversify activities into oil palm production. Bintulu Lumber is so far the only private company involved in an NCRJVG in the catchment area.

In terms of ownership structure and representation, oil palm plantations in the catchment area reflect the general pattern in Miri District, but with minor variations. Some twenty-five companies and state institutions are active in the

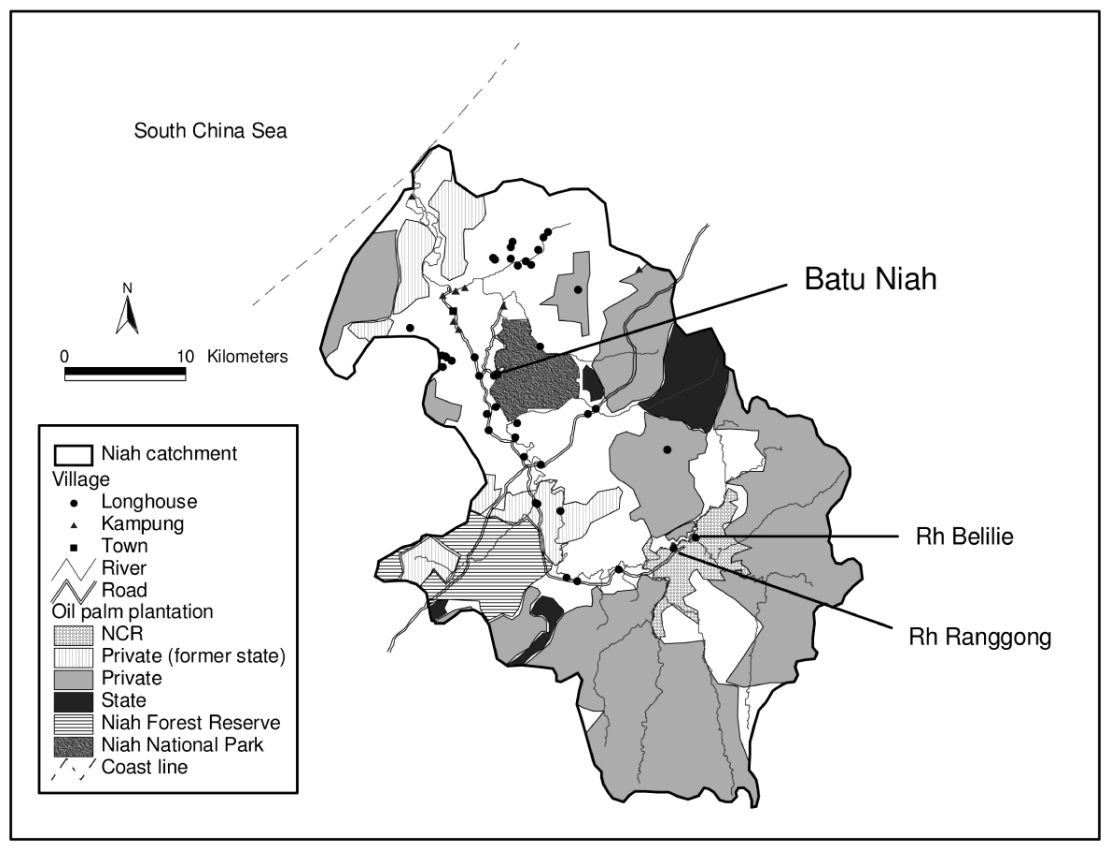

Figure 9.4 Land use in Niah catchment area, Sarawak. 
catchment area, of which eighteen are private companies, including a couple of former state institutions that have been privatised. Among the private companies, local Sarawak companies dominate, with 73 per cent of total allocated oil palm area, whereas companies based in the Peninsula manage 8 per cent of the area. Taken on an individual basis, private companies command larger areas than the various Sarawak state institutions, which control 12 per cent of the land, a modest share but larger than the aggregate figure at the district level (8 per cent). The NCR joint venture projects make up 6 per cent of the land, also reflecting a higher significance of this type of business organisation than in Miri District as a whole (2 per cent). No federal organisation is represented in the catchment area. FELCRA is present but insignificant at the district level.

Small-scale farming systems in Miri have expanded slightly since the early 1970s. These systems have changed from being almost entirely dominated by Iban shifting cultivation that focused on rice production to systems managed by a multitude of ethnic groups that now mainly focuses on cash crop production on permanent fields. The production of vegetables especially has increased during the recent decade. This reflects the emergent and growing demand for food from both locally employed workers in the timber and plantation companies and urban consumers in nearby towns, now served by the improved roads through the catchment area.

This change of cropping pattern is linked to changes in the age composition among the local smallholders and shifting cultivators. Traditionally, young Iban men followed a circular migration pattern, in which they went away from their longhouse for several years in order to gain experience and earn money. Eventually, however, they returned to cultivate their ancestral land. In recent decades, return has ceased to be the norm and migration has become more permanent, with increased urban and overseas employment opportunities. Hence, the physically demanding felling and clearing work, linked to shifting cultivation of subsistence rice, has gradually been replaced by cultivation of cash crops on permanent fields, located in near the longhouses. This type of land use is much better suited to the women and elderly farmers who have remained in the longhouse communities, though women too have also started to migrate (Soda 2001; Hansen and Mertz 2003).

In the present situation there is no coherent state land left in the catchment area that is suitable for oil palm production, provided that the remaining part of the Niah Forest Reserve is maintained as production forest. The only areas not under oil palm plantations are the riverside areas inhabited by shifting cultivators and small-scale farmers (see Figure 9.5), who try to claim the area as NCR Land. However, two other areas in the southeastern part of the catchment area are also projected as private oil palm plantations, both linked to the existing NCR-JVC. One is land compensation to a private company for a wrongly implemented land survey, and the other an extension of the NCR-JVG into the Bintulu Lumber plantation in order to create a coherent oil palm area under the same management. If these plans are implemented, only a small, steep area completely unusable for plantation agriculture will be left without oil palms in this part of the catchment area. 


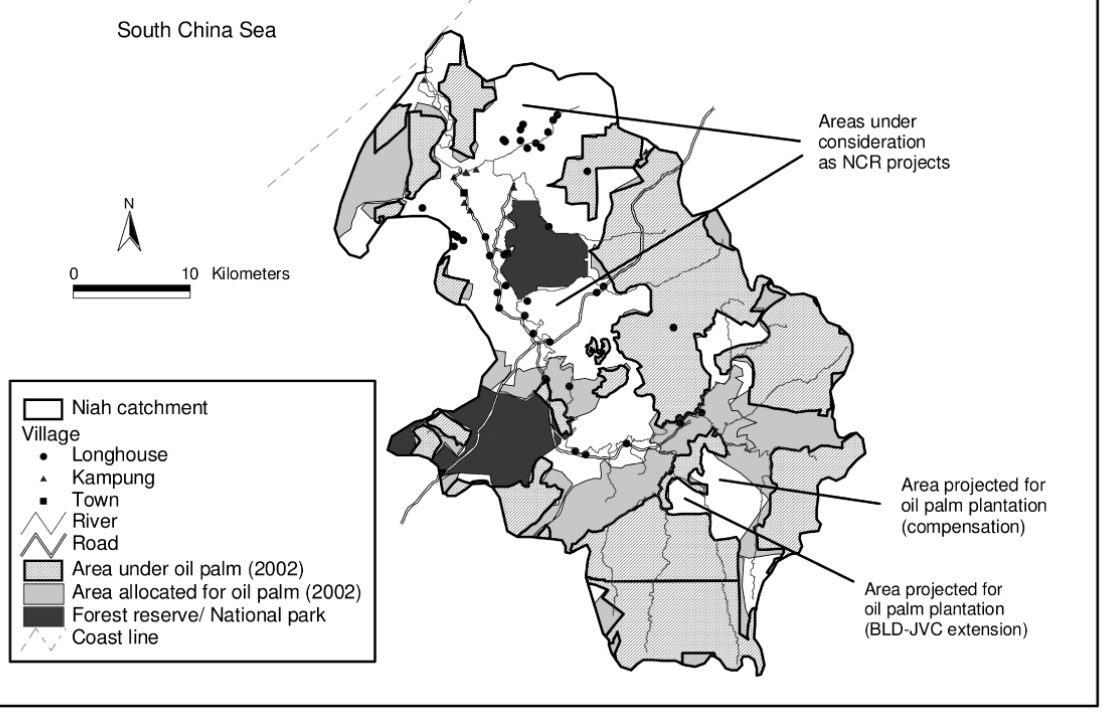

Figure 9.5 Actual and projected areas of oil palm plantation in Niah catchment area, 2002.

Because of the present land scarcity, shifting cultivators (and other small-scale farmers) with considerable land in the catchment area, and thus at least half the settlements, have been contacted by neighbouring oil palm plantation companies. Due to a previous deadly clash between longhouse dwellers from one of the settlements and oil palm plantation personnel, the issue is very sensitive in the area and so not all contacts between the parties are disclosed. (Detailed information about the incident is reported at www.rengah.c2o.org/news; other cases of land disputes are also reported there). With the establishment of the plantations and increased pressure on land resources, nearly all contacts were made during the last part of the 1990s. The contacts fit into four broad categories, as identified by a questionnaire survey covering all 49 settlements in the Niah catchment area. First, and most frequently, farmers have been informed by the company that their land is state land and has been allocated to the company for oil palm production. As mentioned above, this is a common problem in Sarawak as shifting cultivators primarily farm on non-surveyed (NCR) land and so the boundaries between state land and NCR Land are unclear. Second, companies want to expand oil palm plantations on to the small-scale farmers' land through compensation payments to the farmers. Third, companies want to form a joint venture company together with the shifting cultivators (only on NCR Land). Fourth, companies want to build access roads to their plantations. For obvious reasons, nearly all the longhouse settlements with reported contacts to plantation companies are located near to the existing NGR project or in areas under consideration as NGR projects. 
A little less than two-thirds of the settlements in the catchment area have applied for land titles but only 29 per cent have succeeded and now have a title to at least part of their land. More than 50 per cent of the Malay villages have titles to parts of their land, while only 15 per cent of the Iban longhouses have titled land. All the longhouses with partial title to their land are located very near major roads. The rest of the land is NCR Land (where titles cannot be given as NCR Land is not surveyed), Native Area Land or illegal occupation of state land. Due to government policy all Chinese are in principle living and farming on Mixed Zone Land. Strikingly, almost all the settlements with titles have sold part of their land (land along the main roads or close to the urban centres) to Chinese businessmen, while interior areas have been sold or transferred to other longhouse members or farmers from a neighbouring longhouse. Land without official titles is also sold even though the legal foundation for this transaction is unclear.

As many as 19 settlements with NCR Land claims have considered converting part of their land into a joint venture project. The main argument for these settlements participating in the NCR-JVG project is primarily to secure ownership of the land by obtaining titles at the end of the 60-year joint venture. Other reasons include earning an income without having to invest, employment creation for villagers and improved infrastructure. On the other hand, there are several important reasons for objecting to proposals for an NCR-JVC. One set of reasons relates to the lack of sufficient land or unwillingness to give up land that is currently being used for other types of agriculture. The 60 year period is often considered too long and there are doubts about the ability and will of the government to hand over the title after the 60 years. In addition, there is a lack of trust concerning the intentions of the private oil palm companies, and a general hesitance to be the first to move into this type of agreement. Hence, many settlements want to see the results of the existing local project before they are willing to engage in an NGR-JVG project.

Currently there is one NCR project in the catchment area, namely the Ulu Sungai Niah JVG project, involving two longhouses (Rh. Ranggong and Rh. Belilie). The establishment and planting phases of the oil palm plantation are almost finished. However, after the agreement was settled, the longhouses decided to hold back a larger part of their land than initially agreed upon, as many farmers wanted to have sufficient land for their own cultivation. The coverage of the Ulu Sungai Niah project is therefore presently below the formal minimum of 5,000 hectares stated in the NCR-JVG regulations. In two other sites of the catchment area (see Figure 9.5) negotiations are currently taking place between longhouses, oil palm plantations and the government institution (SLDB). The same concerns are present in these cases, leading to an identical reduction in the size of the available land for the oil palm plantations.

\section{Lessons learned? The role of societal contexts for resource frontier expansion}

Frontier expansion in Peninsular Malaysia proceeded through three major phases, with the speed and scope being particularly impressive during the most recent 
phase - from the mid-1960s to the mid-1980s. This phase was centred on oil palm expansion at the expense of virgin forest areas as well as the replacement of former rubber plantations. A serious slump on the world commodity markets in the mid1980s resulted in decreasing prices for Malaysia's main commodity-based exports. From then on the state gradually withdrew from its many direct positions in the agricultural economy, including the financing of land development schemes of various types. Declining involvement of the federal state paralleled more evident limitations in the availability of natural resources - the rapid expansion of oil palms slowed.

The rapid clearing of forests was linked to land being a state matter. Before land was vested in federal resettlement programmes, extraction of available timber and mineral resources were carried out with frantic haste in order to permit private exploitation before public welfare initiatives. Whether the overall development effects of that process are positive or not is somewhat ambiguously interpreted within the framework of the resource frontier model. On the one hand, a number of socio-economic parameters suggest that, at an aggregate level, the material welfare of the population in Peninsular Malaysia, including the majority of rural inhabitants, has been considerably improved (Brookfield 1994c). On the other hand, the rapid expansion of the frontier has resulted in a destruction of the environment that may turn out to be irreversible in certain locations (Brookfield 1994d).

By comparison, resource frontier expansion in Sarawak took place in two phases over a much shorter span of time. The first phase, from the mid-1960s to the late 1990s, was based on tropical hardwood. The second phase, very much subsequent to the first both in time and space, started in the mid-1990s and was based on oil palms. Hence, compared with the Peninsula, oil palm plantations have been established and expanded on land recently cleared of timber, and outside any existing organisational framework such as the rubber plantations in the Peninsula.

The cleared land in the Peninsula was used for resettlement of landless and poor Malays, who moved into increasingly well-organised schemes with houses, infrastructure and various service facilities. Gradually, the geographical scope of the schemes grew to such an extent that they were organised as regional development programmes. In Sarawak, no settlers live in planned towns with service facilities or cultivate the cleared land. Rather, private plantation companies own most of the oil palm land and hire available labour, including foreign migrants. The rest of the plantations were until recently organised by state parastatals as in situ schemes, in which indigenous communities were assisted to enter into commercial agriculture on the basis of large-scale, plantation-like activities.

Due to restricted financial resources in the mid-1990s, these schemes were phased out by the Sarawak state and a new organisational form of communitylinked oil palm plantation scheme was introduced and implemented. The so-called joint venture company concept seeks to combine the land-rich but poor indigenous population with private plantation companies willing to invest in the establishment of a plantation on 'idle' NCR land. A parastatal also participates with equity holdings and regulates the commercial activities according to legal agreements between the parties. By involving the longhouse inhabitants as wage workers and/ 
or 'rentiers', state welfare expenses can be kept at a minimum while 'development' and agricultural modernisation is induced in local communities by means of private capital.

The state is pushing local communities to participate in ventures of a sufficient size to make the operations profitable; a certain minimum area of relatively coherent land with oil palms is necessary for logistical reasons and for the justification of investment in processing capacity. As the evidence from the Niah catchment area indicates, emerging scarcity of suitable plantation land in the vicinity of existing infrastructure and processing facilities seems to be the most important factor behind the drive to establish the NCR-JVGs. Certainly, the hesitant, and even oppositional, stand by most local communities towards the idea of formally handing over control of land resources is in contrast to the eager and somewhat aggressive insistence by the private plantation companies on their legal right to expand plantation activities in these key areas.

Changing land use and migration patterns among the Ibans are caught up in this external pressure, and they make decisions concerning participation in the NCRJVC scheme extremely complex. In the affected communities of the Niah catchment area, shifting cultivation of rice is gradually being replaced by cultivation and marketing of vegetables from permanent fields. This shift is related to the rapidly growing consumer markets (in nearby towns and plantation areas) and intensified by the lack of able-bodied males (who have been attracted by employment opportunities in the logging industry or various urban areas).

These processes are broadly similar to those taking place in the rural areas of the Peninsula, where rice production is being geographically concentrated and urban labour migration erodes the productive potential of rural areas. However, no risk is involved there in terms of a prospective loss of user and property rights to land. Furthermore, the particular way that land access and user rights are organised among Iban longhouse members has resulted in hitherto unknown intracommunity conflicts when land use is shifted towards the NCR-JVC concept. Structural conditions and livelihood strategies of individual households are interwoven within a complicated and contradictory set of socio-economic attitudes towards potential involvement in a new scheme. There is a decisive difference between situating a local community in a state of social and economic flux, marked by internal contradictions (as with the NCR-JVG concept), or a state of mutual pioneer spirit supported by relatively well-developed physical and functional infrastructure (as in the FELDA concept), even though the latter is not without high economic and social costs. Economic resilience and social sustainability are gradually eroded in the former, while the survival of 'traditional' Iban communities is severely threatened by the state's persistent efforts to officially distribute material wealth and protect the environment.

\section{Conclusion}

The speed of frontier expansion, including the implementation of new forms of enclosure, indicates that the established patron-client network between the state's 
political elite and the timber cum plantation companies has changed its material basis. The mutual accumulation of money and political power is now shifting towards palm oil, whereas timber is of decreasing importance. Hence, the economic benefits of development in Sarawak are heavily biased towards an elite group with access to the state apparatus, either directly as elected politicians or indirectly as economic tycoons with substantial influence on the regulation of the economy. In the Peninsula the development process incorporated substantial numbers of landless farmers by opening up new income opportunities, either as wage earners in the labour intensive manufacturing industry, as disguised labourers in the resettlement schemes or as 'rentiers' in the in situ schemes. Some would argue that the elite bias also characterises the accumulation process on the Peninsula, but what differs in Sarawak is the much more limited inclusion of broader groups of the population in the economic growth and distribution of benefits.

On the face of it, the two different trajectories of agricultural frontier expansion in Peninsular Malaysia and Sarawak demonstrate a striking similarity with Auty's (2001) two development models referred to in the introduction to this chapter. Whereas Sarawak seems to fit nicely into the archetypical version of a staple trap model, Peninsular Malaysia resembles a somewhat unique case, where competitive industrialisation and a general increase of material living standards have taken place - despite the abundant endowment of natural resources.

Instead of juggling with the various factors behind this apparent dissimilarity, it is important to stress the implications from a development strategy perspective. The two models are not simply given by nature, but are a function of an evolving political economy. Moreover, agricultural frontier expansion in resource-rich countries can be adequately embedded in socially responsible policies that aim to increase material welfare. This is a function of political will, the legal regime and the strength of the dominating classes and alliances within the particular society and within particular states of different resource bases, hence the substantial differences between frontier expansion in the two distinctive parts of Malaysia. Land legislation ensures that the consequences of such different outcomes will extend far into the future, and demand that much greater attention is given to both the physical and social sustainability of settlements and commercial activities for more than one generation, otherwise overall environmental sustainability is improbable.

\section{References}

Auty, R (2001) The political economy of resource-driven growth, European Economic Review, 45, 839-46.

Brookfield, H, Lian, F, Lok Kwai-Sim and Potter, L (1990) Borneo and the Malay Peninsula, in B L Turner (ed.), The Earth as Transformed by Human Action, Cambridge: Cambridge University Press, pp. 495-511.

Brookfield, H (1994a) Transformation before the late 1960s, in H Brookfield (ed.), Transformation with Industrialization in Peninsular Malaysia, South-East Asian Social Science Monographs, Oxford: Oxford University Press, pp. 1-13.

(1994b) Land use and rural employment changes since 1966, in H Brookfield (ed.), 
Transformation with Industrialization in Peninsular Malaysia, South-East Asian Social Science Monographs, Oxford: Oxford University Press, pp. 63-81.

-(1994c) The end of the 'resource frontier', in H Brookfield (ed.), Transformation with Industrialization in Peninsular Malaysia, South-East Asian Social Science Monographs, Oxford: Oxford University Press, pp. 82-94.

- (1994d) Change and the environment, in H Brookfield (ed.), Transformation with Industrialization in Peninsular Malaysia, South-East Asian Social Science Monographs, Oxford: Oxford University Press, pp. 268-87.

Cleary, M and Eaton, P (1996) Tradition and Reform: Land Tenure and Rural Development in Southeast Asia, Kuala Lumpur: Oxford University Press.

Cramb, R A and Dixon, G (1988) Development in Sarawak: an overview, in R Cramb and R Reece (eds), Development in Sarawak: Historical and Contemporary Perspectives, Monash Papers on Southeast Asia 17, Melbourne: Centre of Southeast Asian Studies, pp. 1-19.

- and Wills, I (1990) The role of traditional institutions in rural development: Community-based land tenure and government land policy in Sarawak, Malaysia, World Development, 18, 347-60.

Department of Agriculture (n.d.) Agricultural Statistics of Sarawak (1970-2000).

Fold, N (2000) Oiling the palms: restructuring of settlement schemes in Malaysia and the new international trade regulations, World Development, 28, 473-86.

Freeman, J D (1992) The Iban of Borneo, London: Athlone Press.

Hadi, A (1994) Agriculture and industry: Towards vertical integration, in H Brookfield (ed.), Transformation with Industrialization in Peninsular Malaysia, South-East Asian Social Science Monographs, Oxford: Oxford University Press, pp. 49-62.

Hansen, T S (2003) A step in the right direction - towards integrated natural resource management in Sarawak, Malaysia, in S Franks (ed.), Water Resources Systems - Water Availability and Global Change, IAHS Publications No. 280, Wallingford: IAHS, pp. 175-83.

- and Mertz, O (2003) Migration, off-farm labour and government policies - three decades of change in shifting cultivation, in O Mertz, R Wadley, and A E Christensen (eds), Local Land Use Strategies in a Globalizing World: Shaping Sustainable Social and Natural Environments, Proceedings of the International Conference, Volume 4, Copenhagen: Institute of Geography, University of Copenhagen, pp. 25-54.

Kaur, A (1998) A history of forestry in Sarawak, Modern Asian Studies, 32, 117-47.

Leigh, M (2001) The new realities for Sarawak, in C Barlow (ed.), Modern Malaysia in the Global Economy - Political and Social Change into the 21st Century, Aldershot: Edward Elgar, pp. 119-32.

Majid Cooke, F (2002) Vulnerability, control and oil palm in Sarawak: Globalization and a new era?, Development and Change, 33, 189-211.

Malaysia Palm Oil Board (MPOB)(2003) Annual statistics: 1975-2002. http://mpob.gov.my.

Ministry of Land Development (1997) Handbook on New Concept of Development on Native Customary Right (NCR) Land, Sarawak: Ministry of Land Development.

Ministry of Rural and Land Development (2003) Home page: http://mrld.sarawak.gov. my.

Ngidang, D (2002) Contradictions in land development schemes: the case of joint ventures in Sarawak, Malaysia, Asia Pacific Viewpoint, 43, 157-80.

Omar I, Shamsuddin, M, Arshad, F, Noh, K and Tambi, Z (2001) The impact of ASEAN free trade area (AFTA) and ASEAN investment area (AIA) on the palm oil industry of some ASEAN countries, paper presented at PROSEA and the Institute of Economics, Academia Sinica, Taipei.

Overton, J (1994) Agriculture and industry in colonial Malaya, in H Brookfield (ed.), 
Transformation with Industrialization in Peninsular Malaysia, South-East Asian Social Science Monographs, Oxford: Oxford University Press, 35- 48.

Ross, M (2001) Timber Booms and Institutional Breakdown in Southeast Asia, Cambridge: Cambridge University Press.

Soda, R (2001) Rural-urban migration of the Iban of Sarawak and changes in long-house communities, Geographical Review of Japan, 74, 92-112.

Sutton, K (2001) Agribusiness on a grand scale - FELDA's sahabat complex in East Malaysia, Singapore Journal of Tropical Geography, 22, 90-105. 


\title{
10 Gan Indonesia's complex agroforests survive globalisation and decentralisation?
}

\author{
Sanggau District, West Kalimantan
}

Lesley Potter and Simon Badcock ${ }^{1}$

This chapter examines intersections between commodity production and traditional agriculture in one part of West Kalimantan, Indonesia, which has in the past been famous for its agrodiversity. However, with increasing emphasis on largescale commodity production, the status of such systems is endangered. The commodities concerned are oil palm and rubber, the first being characterised by varied forms of smallholder production under estate control, the latter involving both government-initiated block planting schemes and traditional 'jungle rubber'. Southeast Asia's rural areas are now thoroughly embedded in international markets, with commodity production edging out subsistence activities and increasingly mobile households drawing at least part of their income from non-farm sources (Elson 1997; Rigg 2001). Rigg and Nattapoolwat (2001), using case studies from Thailand, have termed this process 'de-agrarianisation'.

Global processes increasingly determine local outcomes, especially since the Asian economic crisis, while global commodity price fluctuations affect every household. Yet actual farmer decisions, to be translated into specific land uses and household strategies, remain highly differentiated and dynamic, reflecting the detailed endowment of local environments, politics and cultures as well as individual decision-making that involves 'social agency and local diversity' (Whatmore 1994: 54). In a perceptive analysis of a group of Sulawesi cocoa growers, Tania Li described agency as 'the culturally mediated understandings through which rural people encounter a global crop, the new practices they devise, and the consequences that follow' (Li 2002: 416). Unlike Li's independent cocoa growers, the farmers of Sanggau have faced incorporation into a plantation-based oil palm industry, which has posed a severe threat to local agriculture. However, Dayak culture remains strong, with powerful leaders insisting on maintaining varying elements of the traditional systems, albeit in modified form. Agricultural households have found themselves constrained by competing authority structures, with the individualising and monocultural agendas of oil palm plantations and government rubber schemes being opposed to the communal system of multiple rights in a highly diverse and species-rich landscape.

Smallholder agrodiversity has been a major focus of Harold Brookfield's work from 1992 onwards. Examples of successful farmer practice have been reported 
from various parts of West and East Africa, Yunnan and Amazonia (e.g. Brookfield and Padoch 1994; Brookfield and Stocking 1999; Brookfield 2001), whilst Brookfield lauded the agrodiversity found by researchers there, especially West Kalimantan's complex agroforests or tembawang (e.g. Brookfield et al. 1995: 121-22; Brookfield 2001: 150-51). The tembawang are diverse combinations of fruit and timber trees, usually including the illipe nut-bearing Shorea species, tengkawang. The most famous represent former longhouse sites, which are often very old (up to 150 years). Such gardens are generally entirely communal; family tembawang also exist with more limited shared rights, generally evolving from old rubber holdings. With increasing emphasis on large-scale commodity production, the status of such systems has appeared endangered (Padoch and Peters 1993: 174; Potter 2001: 317).

Complicating agrarian change in Indonesia is decentralisation, instituted in 2001, through which the previously highly centralised state devolved many of its powers to the district level. Decentralisation presented many opportunities for the reassertion of the local, specifically the revival of adat or traditional forms of land tenure, village governance and social organisation. Local 'sons of the soil', previously regarded as backward or marginal by Jakarta, can now assert considerable authority over local resources. The democratisation that has occurred since the fall of the Suharto regime in 1998 and the new power available from decentralisation have resulted in constant challenges to the authority of large corporations, including oil palm plantations. Yet the challenges have taken place against a background of economic insecurity, which has both limited the options open to the actors and reinforced their need to secure their interests. Prominent individuals, such as adat leaders, have been concerned to cement their power bases at hamlet level. The 'tension between advancing modernities and resistant traditions' (Rigg 2001: 45) is strongly felt in many communities.

Under the Suharto regime, large companies (especially oil palm and pulp plantations) were favoured by all levels of government. Since decentralisation, although district officials might have been expected to support indigenous smallholder systems, local administrations, forced to raise much of their own revenue, were anxious to attract investment from large firms and play down areas of conflict. Their task is now more complex as they seek to balance the demands of the various stakeholder groups. Village people have become more assertive in pursuit of their rights, especially over land, and may receive assistance from local nongovernmental organisations (NGOs) who are antagonistic to plantation monocultures. In their work as plantation labourers, local people display some of the typical 'resistance' behaviour identified by Scott (1985) and Peluso (1992), quietly cheating the companies with petty larceny and absenteeism, as they cope with rapid change and continuing economic crisis.

\section{Sanggau district}

West Kalimantan's Sanggau district is an ideal laboratory for testing the resilience of the complex agroforest systems. The district covers a block of territory north and 
south of the Kapuas river, its northern boundary being the international border with the Malaysian state of Sarawak. Sanggau is a strategic corridor in West Kalimantan, being traversed by both the important north-south highway that connects the capital, Pontianak, with the Sarawak border, and the major east-west road along the Kapuas river. People from Sarawak often visit the district during durian harvest, providing a useful outlet for local produce. Internal roads, though sometimes problematic in the rainy season, are good enough to permit the transport of oil palm fruit to estate factories. Sanggau district has the second highest population concentration in the province (with 508,000 people), although the town itself is small, with only 30,000 people and few industries (BAPPEDA 2001). Natural forest cover along the Kapuas river has largely been removed, the landscape being a mosaic of trees, scrub, cultivation and occasional grassland. Much of the area consists of a dense network of villages practising traditional Dayak agriculture. This has included both dry and wet shifting cultivation of rice, tapping of 'jungle rubber' (in which traditional rubber species are mixed with other trees, especially fruit trees) and harvesting of fruits and nuts such as durian and tengkawang. A wet swidden (padi paya) involves sowing the rice in a swampy area after burning the grass or swamp forest. While some drainage may be attempted, there is not the careful water control associated with true wet rice or padi sawah, though the first may evolve into the second (Padoch, Harwell and Susanto 1998). Traditionally, agriculture has been communal, with households holding rights to several parcels of land.

To this varied landscape has recently been added quite extensive plantation development of both oil palm and Acacia mangium for pulp, in addition to some government-induced block planting of improved rubber varieties. Some of these developments have been in support of transmigrants; others have included local people. Sanggau has both the largest area of oil palm in the province and the highest number of rubber smallholders (Disbun Kalimantan Barat 2001). In 1990 it also had the biggest proportion of poor villages (63 per cent). Since then the area under oil palm has greatly increased, but poverty has not declined. The loss of land resources, especially the biodiverse resource represented by tembawang, the decline of rice self-sufficiency and the exposure of villagers both to commodity markets and the economic crisis have undermined economic and social security.

Fieldwork was conducted in a number of villages or hamlets between November 2001 and February 2002. The period was a difficult one for farmers, as prices for palm oil products and rubber were both low while the costs of purchased foodstuffs and agricultural inputs such as fertiliser were high. ${ }^{2}$ This chapter reviews the changing context in a cluster of quite different villages and hamlets as they confront the expansion of plantations and the necessity to make decisions over tembawang.

\section{Oil palm in Sanggau}

Oil palm, originally introduced to the Bogor Botanic Gardens in 1848, became established on plantations in North Sumatra and Aceh in 1911, and the Dutch East Indies had become the world's leading producer by 1938. After Indonesian independence and the acquisition of the estates sector, state-run oil palm companies 
were set up in many provinces, including West Kalimantan, to provide affordable supplies of cooking oil and to boost exports. Smallholder involvement began in 1979, with nucleus estate and smallholder schemes, in which smallholders, known as plasma, acquired two-hectare allotments, but also worked on the core (inti) section of the estate. They were bound to the estate until they had repaid the cost of their holdings, their fruit being processed in the estate factory. From 1986 to 1995 private plantations, using mainly transmigrants, operated a similar scheme. The most recent type of arrangement, with local settlers on private estates, utilises farmer cooperatives to handle necessary credit arrangements. Under this scheme (KKPA), farmers must provide seven and a half hectares of land in return for two hectares of planted oil palm. They work as labourers on the estate during its development phase and are trained in oil palm production. The case studies discussed below mainly follow this system, although there are also 'independent' smallholders, who plant trees on their own land but still have their fruit processed in an estate factory.

During the 1990s Indonesian oil palm area and production increased very rapidly, at first predominantly in Sumatra and then expanding to other provinces, including West Kalimantan. By the onset of the Asian economic crisis in 1997, a high proportion of private oil palm estates were owned by Indonesia's four largest cartels, which were also heavily indebted to various local banks. Bank collapses in one case meant the forced sale of the holdings of an entire cartel, while others had to refinance in a period of greatly restricted credit. A general contraction among producers brought a halt to local expansion, but it allowed Malaysian interests to buy up numerous estate properties (Potter and Lee 1998; Casson 2001). Subsequently the industry has gradually recovered, but the new democratic political environment has meant that companies are forced to pay more attention to the demands of workers and villagers.

In 1990 oil palm in West Kalimantan was mainly represented by a few large government plantations. By 2000 the potential planted area had grown sevenfold, primarily through private estate development, to 311,247 hectares (Disbun Kalimantan Barat 2001: 41). According to the local planning office, 748,000 hectares had been reserved or were intended for oil palm in Sanggau district (BAPPEDA 2001). The area developed was only 152,000 hectares, or half that prepared, since bringing an estate to the point where the commodity is actually planted may take several years. Companies often 'reserve' large areas of land, for which they are subsequently granted a provisional permit. Although they prefer to occupy forested lands, in much of Sanggau companies must negotiate release of land from individual villages or hamlets. ${ }^{3}$ The most important of the large oil palm estates are still the government properties of PTPN XIII, sections of which were established in 1979, especially in the Meliau area and at Parindu, to the west and southwest of Sanggau town (Perusahaan Negara Perkebunan VII 1984).

This chapter compares the relationships between villagers and one government estate with the situation with a private company, Malaysian-owned PT Sime Indo Agro (PT SIA). Sanggau and the adjoining Sintang districts are also sites for extensive Acacia mangium government forest plantations (HTI) operated by the Finnish 
firm Finnantara Intiga, though this is not discussed here. The economic and social impacts of both oil palm and the HTI plantations (Potter and Lee 1998) have evolved since the fall of Suharto, especially in the relationships between oil palm companies and the villages.

Oil palm estates in various stages of development occupy most of the central area of the district, together with acacia plantations and transmigrant settlements (Figure 10.1). Perhaps surprisingly, Dayak villages survive there, using a variety of livelihood strategies, despite the competition for land. The pressure imposed by the large companies also varies. The older government estates initially cleared large areas and paid little or no compensation for destruction of 'fruit trees' on village lands. They have been forced to make belated accommodations with newly vocal villagers. Private companies have adopted different arrangements, with each subvillage a particular bargaining point. The negotiations between the stakeholders have increased official awareness of the tembawang gardens, which occasionally become the focus of violent land disputes. One jurisdictional dispute between two village heads over a cleared tembawang led to the destruction of computers and files in the office of PTPN XIII, whose contractor had done the clearing. The

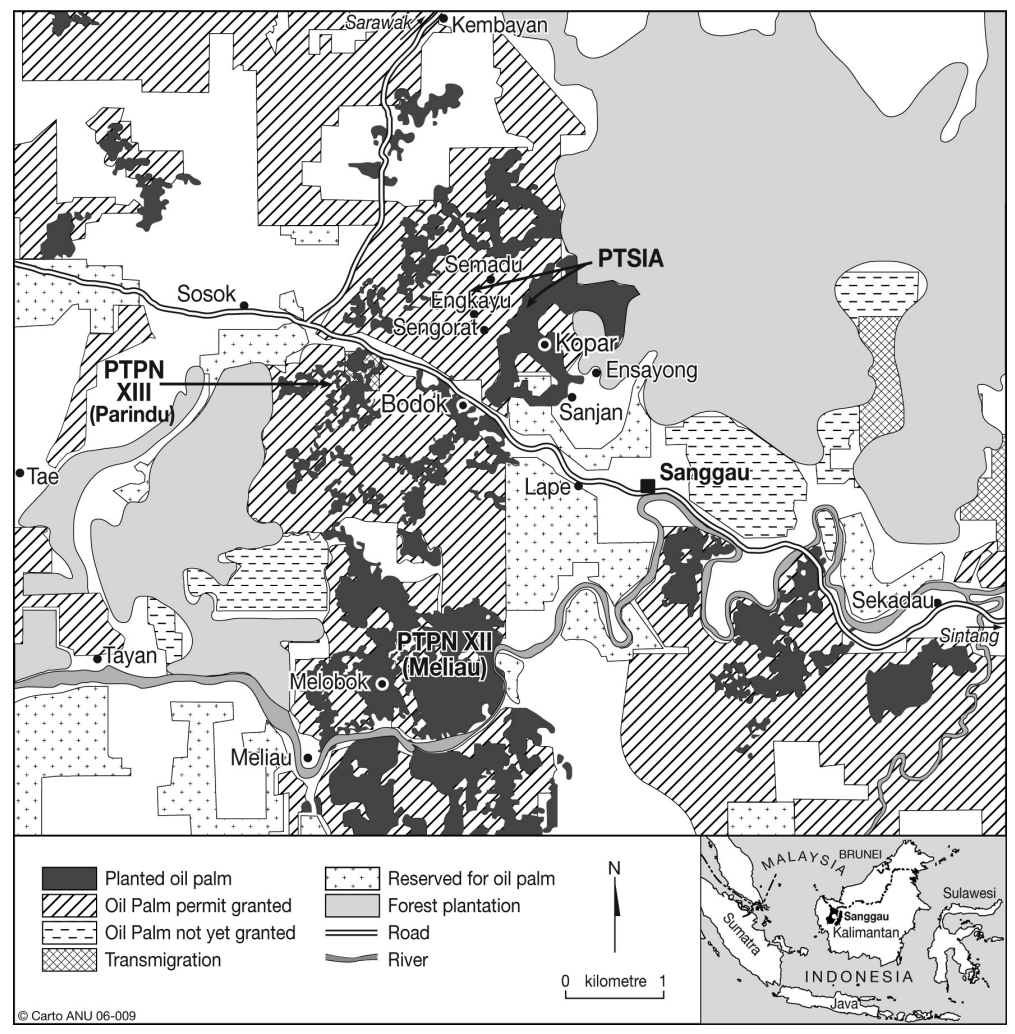

Figure 10.1 Sanggau District, Kalimantan, Indonesia. 
outcome was a huge adat fine levied on the village head who had organised the 'demonstration'.

The critical factors influencing farmer behaviour have been tenure and control over land (communal, family or individual), the influences of particular adat (customary) leaders and other village elite, and economic outcomes, both immediate and anticipated. As resources become scarcer, parents are concerned for the future of their children, keeping their land, or specifically their family tembawang, as the most tangible form of bequest, or putting smaller areas of oil palm in their children's names. Some villagers, convinced that their futures lie with oil palm, have allowed the felling of productive rubber and tembawang, while others have resolutely refused such requests. Some gardens survive only because company pressure has not yet reached them.

Local people recognise that tembawang provide many items for household subsistence, but indigenous fascination with biodiversity is less than that of foreign researchers. To gauge the relative importance of the tree-based system it is necessary to examine its position in relation to the total agricultural mix and its economic opportunities. Harvests of marketable commodities, such as durian and tengkawang, are variable and unpredictable. Tengkawang trees, like other dipterocarps, flower and fruit in accordance with El Niño drought cycles, which occur approximately every five years. Durian also fruits irregularly, but will normally give some sort of harvest each year. The forest gardens are at best a supplementary source of income, although windfall harvests are highly appreciated. Selling tengkawang trees for their timber may be perceived by their owners as a better alternative. ${ }^{4}$

Sanggau is the leading rubber district in West Kalimantan, with twice as many small farmers cultivating rubber as oil palm. Seedlings, together with useful fruit and timber trees, are planted in fallows after a crop of upland or dry rice. The resulting mixed secondary forest provides a low rubber yield per hectare, but the trees are long-lived and hardy. Government projects to supply higher-yielding rubber clones have operated in the district for twenty years, while newer farmbased research trials have been conducted by the International Center for Research in Agroforestry (ICRAF). There has been considerable interest in clonal seedlings, but reliable planting materials are often unavailable or too expensive. Clonal rubber is confined to a few villages able and willing to supply enough land for a block planting (generally of at least fifty hectares) and to a handful of innovative farmers elsewhere.

Farmers have traditionally emphasised rice growing, both dry and wet swiddens being common and a large number of different varieties used. One important aim of rice production has been the making of wine (tuak beras), an important component of Dayak social culture. Wet rice (sawah), with permanent bunds and good water control, is uncommon; existing fields are generally rain-fed, with one crop per year. Many villages have rice barns for storage of excess grain, but few are now self-sufficient. The recent clearing for oil palm has brought rats into the rice fields and declining yields. Farmers see rice growing as uneconomic, though they continue to plant it for cultural reasons.

The fluidity and variability of the present scene are encapsulated in a series of 
short case studies of selected villages or hamlets. Given the homogeneous environment, differences in land use patterns reflect the choices made by the actors, both individually and collectively, as they negotiate tradition, as it currently survives, and the representations of 'modernity' that are available. Strong individuals, both from the estates and among village leaders, attempt to influence households in one direction or another. Despite the persistence of communal traditions, decisions are largely taken at the individual or household level, with some individuals willing to defy the general trend in their particular area.

\section{Sanggau villages}

\section{Lape and Sanjan: accessible villages resisting oil palm}

These village perspectives emphasise both similarity and difference. Lape and Sanjan are settlements that, for different reasons, have resisted the blandishments of plantations and fully retained their tembawang. They specialise commodities other than palm oil: wet rice and durian in one village and improved rubber in the other.

The people of Lape village cling tightly to their land resources, though they no longer make the most economic use of them. The village is close to Sanggau town, along an asphalted road, and a quarter of its households are either civil servants or retired. Lape specialises in rice production and fruit selling, though it was once famous for its rubber. Old tembawang gardens (former longhouse sites) cover 318 hectares and are accessible to all. Other gardens, passed down by inheritance, are under joint family ownership. Traditionally the family member inheriting the parents' house upheld the adat laws within the descent group, all of whom must approve any tree felling on family land (Momberg 1992). Useful trees include petai (Parkia speciosa), manggis (Garcinia mangostana), rambutan (Nephelium spp) and durian (Durio zibethinus) plus many lesser-known species. Once individually owned rubber trees are no longer productive, the land may either be cleared and replanted or left for at least fifty years to become a new tembawang. There is an extensive but depleted community forest reserve, which provides access to some wood for house building as well as fungi, leafy greens and medicinal products. Most timber originates from regrowth scrub, though smaller family-owned forest reserves also exist. A few hectares of Imperata grassland remain unused.

A previous adat leader had allowed people to clear tembawang as long as they paid a fine. Fines and penalties (tael) are still exacted from those who fell trees, such as durian, without permission. As well as traditional clay cups (mangkok), the people fined have to provide meat, either chicken or pig, and often arak (rice liquor). If the fine is three tael they will have to pay Rp350,000 to Rp420,000, which includes the cost of twenty-five to thirty kilograms of pig meat and is worth more than a month's wages.

Most families owned four to five hectares of mixed rubber garden, from which they were able to tap three to five kilograms of rubber per day. Yields have dropped since the late 1980 s and the village no longer depends primarily on its rubber. 
Farmers have expressed interest in improved varieties but have not yet tried them, since holdings are scattered and multiple claimants to land must be consulted.

Lape possesses quite extensive wet rice fields. Plots are individually owned and produce sufficient to cover household needs, with yields four times as high as the dry (ladang) types. Numerous local rice varieties are planted, especially mungo pulut, used for wine, while improved types include new 'Green Revolution' rice varieties: IR64, Cisadane and PB5. In a novel mix, 'weedicides' and hand tractors were used to prepare the wet rice fields, while a traditional gawai ceremony marked the harvest, presided over by the temunggong or adat chief.

People value tembawang but there are few markets for the more exotic species. The tengkawang harvest in 2002 was the first since 1997, causing some excitement, with everybody collecting the nuts and village traders handling large quantities. In the three-week season, November to December 2001, more than a hundred women from Lape sold durian along the road to Sanggau, especially to people from Kuching (Sarawak) who paid higher prices and bought fruit by the carload. That activity brought an income of Rp500,000 to Rp1,000,000 per seller.

People are willing to try new commodities provided that they can retain their land. They dislike oil palm and acacia, and twice rejected overtures from the government oil palm plantation, which borders the village. The current KKPA scheme, whereby smallholders provide seven and a half hectares of land to a company in return for two hectares of established oil palm, was not perceived as fair or attractive, with people feeling that they were becoming 'coolies' on their own land. However, in 1998 a teacher bought twenty hectares of former rubber gardens, which he planted with oil palm, and began selling fruit to PTPN XIII, the first in Lape to do so. Oil palm was said to be restricted here because so much land was held under common property arrangements, but private sales now take place.

Clonal rubber was introduced in 1982-83 to the nearby hamlet of Sanjan, through a government financed Smallholder Rubber Development Project (SRDP), and it has therefore been able to improve its rubber output while retaining most of its old tembawang. Gardens lie along the river; the oldest, which go back eight to nine generations, share rights with the adjoining hamlet of Nyondang, although the latter was accused in the past of unsanctioned tree-felling (Momberg 1992). Some farmers have intercropped their clonal rubber with mixed fruit trees in the traditional style, using pineapples as a cover crop, although such mixtures were forbidden by the original project, and yields are not as high as in monocropped rubber. Tengkawang trees are excluded from such systems as they are too competitive with rubber and must be specially planted in older, unproductive gardens. Ten people in Sanjan are able to graft rubber trees and there has been independent replanting with new stock; however, young farmers who cannot afford improved seedlings continue to use the old type. Sanjan is a specialised rubber-producing village, being able to sell about a tonne of latex per day. Apart from the 'windfall' of tengkawang, people are inactive in marketing other fruit; neither do they spend much time and effort in rice growing, except when they are replanting or expanding their rubber holdings.

As in Lape, farmers in Sanjan will not join any oil palm project. This is because 
they would have to give up too much land. The oil palm company PT SIA is, however, perceived as a useful source of fertiliser, which is resold illegally in Sanjan after being distributed by the company to participating farmers. Both villages thus exhibit aspects of 'de-agrarianisation': many in Lape do not derive all their income from the land, while some farmers in Sanjan simply specialise in rubber, without bothering to grow rice to secure their subsistence. Both villages have sufficient resources to be able to reject the oil palm companies.

\section{Melobok village, Meliau area: site of an early government oil palm plantation}

The government PTPN XIII oil palm estate began in 1979 and has 40,000 hectares of company-worked land spanning three subdistricts (Meliau, Tayan and Kapuas). During the development of these plantations, with no smallholder component, the government compensated only those few households with individual legal titles. Much of the employment on the core estate areas went to transmigrants: work available for local people was limited to day labouring, where the daily wage of Rp7,500 (US $\$ 0.75$ ) was barely enough for survival.

Tembawang gardens as well as fruit groves were destroyed when the plantation was developed, and large fruit trees and rubber gardens were lost to fire in 1997. No older tembawang gardens remain, only younger replanted fruit gardens. Melobok village has one common area, where everyone may access fruit resources, but there is no family-based tembawang. The village economy was previously based on shifting cultivation and jungle rubber, and both upland rice and rubber remain important. The rubber is old, however, and much is now untapped. Many types of upland rice are grown, but experimentation with improved varieties failed when the crops were eaten by birds. In mid-1997 villagers in Meliau subdistrict demonstrated, erecting barriers and preventing the factory from operating for eleven days. The primary complaint was the destruction of tembawang gardens and fruit groves by the plantation. As a result of the demonstrations, people were able to demand assistance to develop their own oil palm gardens using the KKPA model, and they also received a subsidy of cheap rice at the height of the economic crisis.

Through the KKPA development scheme, between 800 and 900 hectares of oil palm will be divided between five villages in the Gunung Meliau plantation area. The inhabitants of Melobok had little land left to offer for new oil palm, as so much had already been consumed by the original plantation. Any land provided to the company will be converted to oil palm on a 1:1 ratio and, after clearing, people will receive Rp175,000 per two hectares per month as a type of management fee. Those without land will work as labourers in the development of the gardens (they are paid the same inadequate daily rate of $\mathrm{Rp} 7,500$ and are guaranteed between twenty-three and twenty-five days work a month). With the estate responsible for seventy per cent of income in this area, people are committed to oil palm, and have used their new found negotiating 'muscle' to finally secure a better deal from the government company. 


\section{Five hamlets and the Malaysian company, PT SIA}

The PT SIA company arrived in Parindu subdistrict, northwest of Sanggau, in 1995 and began planting in 1998, affecting five hamlets, whose farmers made contrasting land use decisions. In its attempts to obtain sufficient land for a viable holding, PT SIA was relatively successful in its negotiations with Kopar, Engkayu and, to some extent, Sengoret hamlets, but it made little headway with either Semadu or Ensoyong. The situation of these hamlets is summarised in Table 10.1. The following discussion examines the causes of differences between the hamlets, and focuses on the four 'typical' commodities of the area: oil palm, tembawang fruits, rubber and rice.

Semadu was originally the most oil palm oriented, with seventy per cent of its households opting for independent planting before the arrival of the company. Unfortunately, two resulting cooperatives both had funding problems, especially after the economic crisis, which resulted in the demise of one. The other, Goda Berjaya, was barely limping along, unable to afford the levels of fertiliser that would secure a good yield and obtaining minimal profit for most of its participants.

Goda Berjaya had been operating since 1994 with people from both Engkayu and Semadu. Working collectively, the group cleared and planted forty hectares of alang-alang (Imperata cylindrica) grassland, with oil palm, using both private and bank credit. Agrarian information was sought from the government estate at Parindu, which also supplied planting material. People began to harvest the fruit in 1997. Two members split from the original group in mid-2001 as they disagreed with the work ethic of the majority. The independents achieved an average of eight tonnes of oil palm per month from their two-hectare gardens, selling the fruit to PTPN XIII. One estimated his average monthly return as Rp1,003,000, clear of transportation, credit and insurance costs. The remaining nineteen farmers continued to harvest and transport communally, but many were no longer motivated to maintain correct practices or improve yields. There was little incentive for anyone to work hard, particularly when yields were pooled collectively and incomes divided. Because they did not manage the gardens well (in particular, they could afford little fertiliser), their yields were much lower, only about one tonne per hectare per month. On average these farmers only made a monthly profit of Rp150,000 to Rp200,000. Their lack of legal tenure over the lands was a great impediment, as further bank finance might otherwise have been forthcoming.

Ensoyong resembled Sanjan in its preference for rubber, even though the clonal varieties available from NGO sources were not necessarily reliable. The head of Engkayu hamlet, noted for his advocacy of PT SIA, suggested that Ensoyong farmers had rejected the company when rubber prices were high and were regretting that decision, and were experiencing financial problems while waiting for their rubber to mature.

None of the other three hamlets had originally opted for oil palm, but they had come around to accepting the 'deal' offered by the company. Kopar, in particular, had been persuaded by new road construction and by the employment opportunities available at the company headquarters. One couple in Engkayu argued that by 


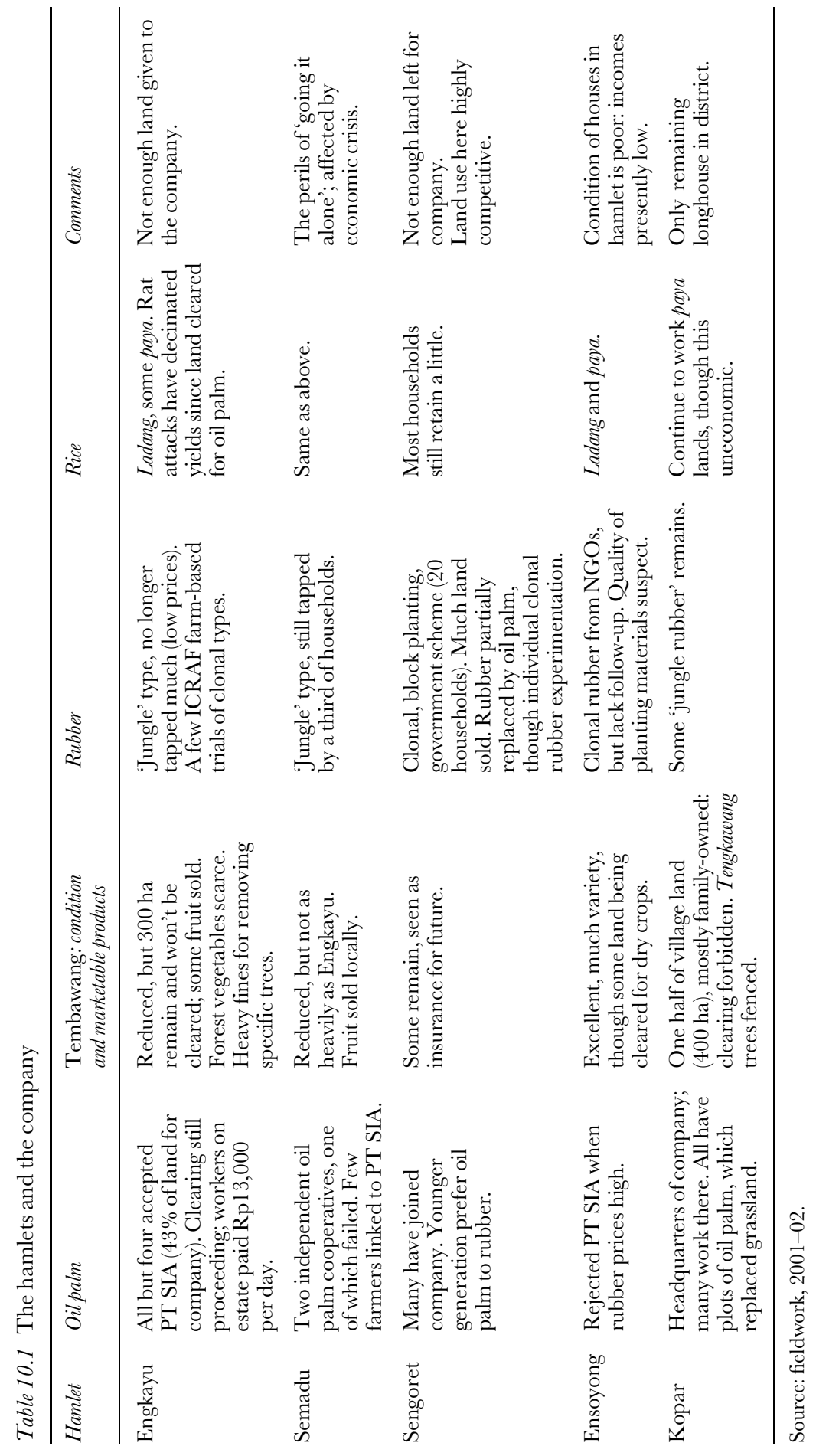


working for the company they could earn Rp300,000 per month, while rubber tapping generated at most Rp200,000. In Sengoret, people were even ignoring their mature clonal rubber trees and concentrating on oil palm, stating that they preferred such work. The four households in Engkayu who refused to give up land for the company found themselves regarded as backward, troublemakers or simply foolish. They in turn accused the company of squeezing as much as possible out of local farmers and village leaders of receiving bonuses to sign up the entire village.

PT SIA had initially stated that it had enough funds to develop 20,000 hectares of oil palm, but had only been able to plant 8,300 hectares by February 2002 and there were problems with supplies and fertiliser stocks. Officers employed to check the work in the field had little authority to enforce proper practices. Some labourers did not properly fertilise the oil palm, but rather stole fertilisers and herbicides for resale elsewhere. ${ }^{5}$ The more distant parts of the estate were not well managed. Responsible villagers who had joined the scheme were concerned about the poor quality of work done and its effect on their subsequent production. Workers, supposed to be employed between 7 a.m. and 2 p.m., sometimes walked off the job after 9 a.m.: being absen was a widespread practice, yet nobody had been sacked. It was argued that workers would be more responsible if they were penalised with adat sanctions. When they eventually take control of their two hectares, farmers will have to repay between Rp26 million and Rp28 million in credit, an impost which many will find difficult, but which they overlooked in their eagerness to receive the company's wages.

The company realised that few villagers were in fact delivering the official seven and a half hectares of land. Most were trying to receive the same benefits with a smaller land donation, and in hamlets such as Sengoret so much land had already been sold that it appeared impossible for quotas to be met. Attempts were made by the company to pay for only twenty-six per cent of the fruit harvested, which represented the proportion contributed by the farmers; the farmers then demonstrated and were paid the full amount, but from a company perspective the situation was unsustainable. The manager of PT SIA threatened to take the matter to court, which was unacceptable to Sanggau officials, who were keen to promote the district's potential for investors and developers.

\section{The position of the tembawang}

All five hamlets had retained some tembawang but, except for Ensoyong, the gardens were reduced in size and had become depleted of valuable species. Sanctions against further clearing of complex agroforests existed, especially in Engkayu and Kopar, where adat leaders were strong and could enforce penalties more readily. The decline in resources was particularly felt in Engkayu, which had a wider range of penalties for unsanctioned felling of trees than Lape. The fines varied from a quarter of a tael for tengkawang, ${ }^{6}$ to one tael for the locally endemic orange durian pekawai (Durio kutajensis) and to three tael for ordinary durian (half the size of the durian fine in Lape). As in Lape there was a fine of twelve tael for destroying a honey tree (Koompassia excelsa). The fine for tampoi merah (Baccaurea ramiflora), at six tael, was 
the second most severe as the fruits are used to make wine (tuak tampoi). A host unable to serve guests alcohol will feel great shame, hence the large penalty for destroying the trees. The situation with respect to adat fines has been changing, however, with some flexibility in the sanctions imposed, depending on the size and maturity of the trees and the history of their yields.

Although they collected tengkawang, nobody in Engkayu specialised in producing fruit because of its unpredictable yields and low prices. One of the villagers who had resisted joining the company sold pekawai in the nearby towns. He could transport forty fruit per trip, which would bring between Rp25,000 and Rp40,000 per day. He also sought forest vegetables and river fish, but few wild vegetables remained after so much land had been cleared. People were forced to buy vegetables from outside, a previously unheard of situation. Oil palm estate workers received a daily wage, but for non-conforming farmers like these the daily income was unpredictable.

While the western part of Kopar (previously alang-alang and unused) had been converted to oil palm, the eastern part, up to 400 hectares, had been retained. It consisted of a series of tembawang, mostly family owned, with diverse tree species, other forest fruits and timber resources. People were allowed to collect any fallen fruits, but were only permitted to harvest fruit from their own trees. Areas of tengkawang were often closed off with bamboo or fenced to deter would-be gatherers. In 2002 the nuts were collected, peeled and sold to traders in Bodok for Rp1,000 per kilogram. In the past people had tried to convert tembawang gardens to dry rice or vegetables, but such conversions were now banned. There had been a significant reduction in the amount of tembawang in the subdistrict: some hamlets had no gardens at all, while others were actively clearing garden land. The adat head did not want to promote the clearance of tembawang while other sources of income were available. However, areas of unproductive old rubber could be cleared and replanted. When in 2001 a villager illegally cleared two hectares of tembawang in a neighbouring hamlet, the Kopar head was called in to help resolve the dispute as he was a senior adat figure. The offender was sanctioned twelve tael, or about Rp2.4 million, and the land was replanted with rice and fruit trees and returned to its owner.

\section{The position of rubber}

While efforts were made to maintain the tembawang against pressures from oil palm, neither rubber nor rice fared as well. Rubber largely remained untapped in Engkayu and Kopar, with farmers only tapping if they needed to purchase goods from the shops. About thirty households in Semadu still tapped rubber as their primary income source, but most worked with oil palm. In Sengoret the clonal rubber program began in 1987. Twenty households followed the governmentsponsored SRDP, which assisted families with planting materials and fertilisers for five years. The land was severely restricted: project organisers wanted contiguous blocks, which was impossible for those wanting to join the scheme but without land in the proposed area. That project was initially scheduled for Engkayu, but one 
farmer refused to sacrifice his new jungle rubber, while project staff insisted on clonal rubber only. At one clonal rubber garden, a young couple were tapping the family trees. They only did this in their spare time, though they admitted that it was best to tap as regularly as possible otherwise yields would drop. Both worked at PT SIA for a maximum of twenty-four days per month and were paid Rp13,000 per day. They preferred to work with the company as it was much easier than tapping rubber, where the work ethic of the farmers determined yields. Another farmer had provided PT SIA with more than thirteen hectares of productive mixed rubber garden (yielding between five and ten kilograms a day). He regretted that decision but did it to give his children a future source of income from oil palm. He believed clonal rubber to be a profitable commodity if the gardens were well maintained, but considered that the trees did not last as long as those of jungle rubber.

One of the largest landowners in Sengoret was an agricultural extension officer, who had moved there because land was cheap. He had acquired thirty hectares, paying as little as Rp40,000 to Rp60,000 per hectare. (Before the oil palm company arrived, many people in Sengoret had already sold land, either privately or to the government for the clonal rubber project.) The agricultural officer had clonal rubber gardens with a number of improved species not yet tappable; he reasoned that if farmers had a combination of both oil palm and clonal rubber then they would be better off, as both commodities had strengths and weaknesses. He had joined the oil palm scheme and provided almost fifteen hectares of land, but observed that market price fluctuations would create problems for local growers who had reduced their options. However, he believed that PT SIA's presence had led to intensification in farming practices, being more of a catalyst for change in the region than any government agency. In 2000 a representative from the Dayak Adat Council provided sixty-four participating farmers in Ensoyong with fertiliser, clonal rubber seeds and 'weedicide'. However, there was no guarantee that the seed stock used in this initiative was true clonal rubber and not simply cloned jungle rubber seedlings, a common substitute. The farmers received little follow-up information. An NGO group from Sintang also helped villagers with clonal rubber gardens, with the original planting being done communally. An implication of such low-level projects is that farmers will be discouraged by unsatisfactory latex yields. If trees only generate between three and five kilograms per hectare, farmers may be tempted to clear the rubber gardens for oil palm, particularly if they see neighbouring hamlets developing and progressing under monocultures.

\section{The position of rice}

Most farmers grew rice using swidden methods, with numerous upland varieties. Before rats began to affect production it had been possible to harvest one and a half tons of rice per hectare, but with the development of oil palm there was little time or energy for people to plant, tend and harvest rice crops. In 2000 the rice harvest was reasonable, whereas in 2001 there was virtually no harvest, and by February 2002 much had already been destroyed. One woman in Engkayu, who had had earlier welcomed the company, now felt the price had been too high. After the land 
clearance, rats had decimated their rice crop. Rice harvests in the past had been sufficient for seven months, but now there was only two months' supply, making it scarcely worthwhile to plant and tend the fields. Costs for all purchased commodities, (basically rice, coffee and sugar) were very high given the wage levels. Because of the rural crisis, traders would not extend credit as people could not repay it.

From an economic point of view it was no longer rational for people in Kopar to plant rice as yields were very low, though some continued for cultural reasons, notably for tuak production. When time and other inputs were estimated, the head believed he would lose fifty per cent of the money he had invested in the crop. Most people had up to one hectare of land under padi paya while a few continued with dry swidden.

\section{The five hamlets}

Throughout these hamlets a modified multi-cropping system is emerging, with oil palm largely replacing rubber and rice, but with certain areas of tembawang being allowed to remain. Unless further tree planting takes place, however, as was happening in Meliau, the tembawang portion of the multicropping system will become fossilised and will probably gradually disappear.

\section{Conclusion}

Among the eight villages and hamlets studied, only three had tembawang remaining almost intact: Lape, Sanjan and Ensoyong. All had economic problems, which were most severe in Melobok, the community with the longest experience of oil palm and the largest land losses to the plantation. Those in Parindu subdistrict that had accepted PT SIA were in an intermediate position, managing to retain some tembawang and rubber gardens while receiving a reasonable income from working for the company at wages well above the rates at PTPN XIII. Households had the option of choosing between activities, with Sengoret best placed as it already had clonal rubber despite its severe land shortages. However, it was unlikely that the 'good times' would continue for long. When planting is finished, estate labouring jobs will decline and the responsibility for growing oil palm will revert to the villagers, together with the need to repay the company's credit. Far-sighted farmers in the region anticipate future difficulties and plan to overcome them. Others simply adjust to new situations as best they can, though they are no longer passive in the face of injustice. The continuation of adat sanctions remains strong, though not universally so, and remains respected where other rules are flouted. The decline of rice growing was keenly felt by those affected, but this important cultural activity continued on a limited scale despite its economic irrationality.

In terms of biodiversity and its maintenance, the germ plasm of the tembawang appeared to be reasonably intact in a few villages, though some items were being depleted. Thanks to El Niño there were tengkawang harvests, but the numbers of trees had markedly declined as their timber was in demand. Critical shortages of timber species for construction, and of forest vegetables, were beginning to occur. 
Various other fruits were consumed and valued locally, but could not be relied upon as a supplementary source of income.

The farmers of Sanggau district hold resources but are unable to produce capital, a situation evident elsewhere (Soto 2000). Their joint rights in many pieces of land restrict their ability to rationalise their holdings and improve their incomes, for example as independent clonal rubber producers. A struggle was taking place between the advocates of a communal, more traditional lifestyle and those preferring a freer, more individualistic approach. Debate was keen in villages such as Lape, where the restrictions of the communal approach were evident. Communal efforts to work oil palm cooperatives led to failure in one example and minimal profit in the other, as management faded. Many smallholders substituted one income source for another, rather than seeking to maximise particular ones. A few ambitious individuals broke clear of the mould, though sometimes at the expense of their fellows. Such individuals planned over the long term and took an independent stand, though often being castigated as troublemakers.

Heartening for advocates of agrodiversity, tembawang were being specifically retained, though as much for their symbolic significance as their economic or environmental value, in the face of the inroads of oil palm. They were seen to represent tangible symbols of the history of a community grounded in its landscape, what Mayer (1996) has called 'landscape capital', and symbols of the continuing power of adat chiefs, whose ability to impose expensive sanctions for unauthorised felling of trees was feared and respected. Where the tembawang had been destroyed, as in the case of Melobak village, they were being replanted: a small beginning, perhaps, but an assertion that they were perceived as still significant in ensuring a sustainable resource base and cultural continuity for the next generation.

Complex agroforests may therefore survive in some form if village leadership continues to promote them and local people value them, even if primarily as insurance for the future. At least in 2002 the oil palm companies were struggling to win the battle of the minds, although the contribution of PT SIA to local incomes was appreciated. The continuing rural crisis, in which low global commodity prices were coupled with high costs of purchased food and agricultural inputs, had placed communities under severe stress. They may not have wanted to accept oil palm, but they were finding they had little option in the short term; yet this outcome was basically unsustainable, as the forms of protest adopted to express resistance to the company, such as poor maintenance of the gardens and lack of fertiliser, would rebound on future owners, who had not only to make a living from their twohectare plots, but also to repay the costs of their establishment.

The likely impact of decentralisation remains unclear. Although there has been talk of a revival of adat in villages, the exact form that this might take seems uncertain. In West Kalimantan, wracked by interethnic violence in 1997-98, solidarity among Dayak groups is strong, and local NGOs offer support. ${ }^{7}$ Indeed a protest by Dayak groups against the conversion of community-managed land to oil palm led eventually to the formation of AMAN, the nationally based Alliance of Adat Communities, which was growing in strength (Bamba 2000; Moeliono 2002). NGOs tend to be antagonistic toward oil palm plantations, but local attitudes are 
more ambivalent, and many see the industry as useful and important for local economies.

Complex processes operate at local levels in Indonesia, representing the struggles between modern, globally oriented industry, notably oil palm plantations, and the aspirations of villagers. The latter seek to reconcile tradition and modernity to obtain future security for their children and improve current family welfare. Preservation of the tembawang mixed gardens, as an element of the livelihood mix, ranks highly, hence a new accommodation is being found to enable both the traditional and the modern to coexist. Yet this accommodation may be being forced on people by strong adat leaders as an assertion of their power. The extent to which individual families would favour this option, if they were free to choose, still remains unclear. Uncertainty underlies agricultural strategies.

\section{Notes}

1 We acknowledge the assistance of many individuals in the study villages, in the government estate crops sections in Sanggau and Pontianak, at PT SIA, Finnantara Intiga, ICRAF clone rubber project and the GTZ Social Forestry Development Project. The project was funded by the Australia Research Council, the support of which is acknowledged.

2 Local prices paid for rubber were about Rp2,000-2,150/kg in the villages, while purchased rice cost Rp2,600-3,000/kg, depending on its quality. For other essentials, a kilo of sugar cost Rp3,800 in the township of Bodok and Rp4,600 in a nearby village, while an ounce of coffee was Rp2,000 in Bodok and Rp2,500 in the village. Prices paid for oil palm fruit bunches by the factories were only Rp300-325/kg, where 'break-even' rates were estimated to be Rp450/ $\mathrm{kg}$. Conversion rates for the Indonesian rupiah at the time were about Rp10,000 = US\$1.00.

3 Generally the negotiating unit is a hamlet, or subvillage, rather than an official 'village'. The land-holding unit, descendants of a few families who had originally cleared the forest in a particular location, has been the hamlet (dusun). Sanggau district administration is planning to revert to the dusun as the official unit, replacing the cumbersome village structure of the Suharto regime's time.

4 Though marketing tengkawang wood is supposedly illegal (Peters 1996: 236), the trees are in demand as meranti timber and used in furniture.

5 During fieldwork one author visited a small shop in a rubber-growing village where imported fertilisers marked 'not for resale' were being sold. Before the company organised security there were numerous problems with graders and bulldozers being stolen at night.

6 There are apparently few sanctions against cutting tengkawang, which cash-short villagers will often sell to generate urgently needed funds.

7 The Pancur Kasih Foundation was established in 1981 by Dayak teachers in Pontianak to work towards better conditions for Dayak communities. It has since set up several NGOs, credit unions and a bank (Bamba 2000).

\section{References}

Bamba, J (2000) Land, rivers and forests: Dayak solidarity and ecological resilience, in J Alcorn and A Royo (eds), Indigenous Social Movements and Ecological Resilience: Lessons from the Dayak of Indonesia, Washington DC: Biodiversity Support Program.

BAPPEDA (Badan Perencanaan Pembangunan Daerah) (2001) Upaya peningkatan 
perekonomian Sanggau melalui kelapa sawit (strategi perencanaan), unpublished paper prepared for seminar Problematika Perkebunan Sawit di Kabupatan Sanggau, 25 August, Jakarta.

Brookfield, H (2001) Exploring Agrodiversity, New York: Columbia University Press. and Padoch, C (1994) Appreciating agrodiversity: A look at the dynamism and diversity of indigenous farming practices, Environment, 36 (5), 6-11, 37-45.

— and Stocking, M (1999) Agrodiversity: Definition, description and design, Global Environmental Change, 9, 77-80.

—, Potter, L and Byron, Y (1995) In Place of the Forest: Environmental and Socio-economic Transformation in Borneo and the Eastern Malay Peninsula, Tokyo: United Nations University Press.

Casson, A (2001) Decentralisation of Policy-making and Administration of Policies Affecting Forests and Estate Crops in Kutai Barat District, East Kalimantan, CIFOR Reports on Decentralisation and Forests in Indonesia, Case Study 4, Bogor: Center for International Forestry Research (CIFOR).

Disbun (Dinas Perkebunan) Kalimantan Barat (2001) Perkebunan Dalam Angka Kalimantan Barat, Tahun 2001, mimeo, Pontianak.

Elson, R (1997) The End of the Peasantry in Southeast Asia: A Social and Economic History of Peasant Livelihood, 1800-1990s, Basingstoke: Macmillan.

Li, T (2002) Local histories, global markets: cocoa and class in upland Sulawesi, Development and Change, 33, 415-37.

Mayer, J (1996) Trees vs trees: Institutional dynamics of indigenous agroforestry and industrial timber in West Kalimantan, Indonesia, unpublished $\mathrm{PhD}$ thesis, University of California, Berkeley.

Moeliono, M (2002) Adat and globalization: living apart together, paper for the International Association for the Study of Common Property, 9th Biennial Conference, Victoria Falls, Zimbabwe.

Momberg, F (1992) Resource management of Dayaks in West Kalimantan, GTZ Report, Berlin: Social Forestry Development Project (typescript).

Padoch, C and Peters, G (1993) Managed forest gardens in West Kalimantan, Indonesia, in G Potter, J Cohen and D Janczewski (eds), Perspectives on Biodiversity: Case Studies of Genetic Resource Conservation and Development, Washington DC: American Association for the Advancement of Science.

-Harwell, E and Susanto, A (1998) Swidden, sawah and in-between: Agricultural transformation in Borneo, Human Ecology, 26, 3-20.

Peluso, N (1992) Rich Forests Poor People: Resource Control and Resistance in Fava, Berkeley, CA: University of California Press.

Perusahaan Negara Perkebunan VII (1984) First in West Kalimantan: Gunung Meliau Palm Oil Mill, Pematang Siantar, Indonesia, mimeo, Pontianak.

Peters, C (1996) Illipe nuts (Shorea spp) in West Kalimantan: use, ecology and management potential of an important forest resource, in C Padoch and N Peluso (eds), Borneo in Transition, Kuala Lumpur: Oxford University Press.

Potter, L (2001) Agricultural intensification in Indonesia: outside pressures and indigenous strategies, Asia-Pacific Viewpoint, 42, 307-26.

Potter, L and Lee, J (1998) Tree-planting in Indonesia: Trends, Impacts and Directions, Occasional Paper No 18, Bogor: Center for International Forestry Research (CIFOR).

Rigg, J (2001) More than the Soil: Rural Change in Southeast Asia, London: Prentice Hall.

Rigg, J and Sakunee Nattapoolwat (2001) Embracing the global in Thailand: activism and pragmatism in an era of de-agrarianisation, World Development, 29, 945-60. 
Scott,J (1985) Weapons of the Weak: Everyday Forms of Peasant Resistance, New Haven, CT: Yale University Press.

Soto, H de (2000) The Mystery of Capital: Why Capitalism Triumphs in the West and Fails Everywhere Else, London: Bantam Press.

Whatmore, S (1994) Global agro-food complexes and the re-fashioning of rural Europe, in A Amin and N Thrift (eds), Globalization, Institutions and Regional Development in Europe, Oxford: Oxford University Press, pp. 46-67. 


\section{Seeing 'water blindness' \\ Water control in agricultural intensification and environmental change in the Mekong Delta, Vietnam}

Fiona Miller

The study of land, its development, degradation and control, has been central to research on rural development and environmental change. Harold Brookfield has made a notable contribution to this and to our understanding of the political dimensions of society-environment relations. Although Brookfield addresses social and environmental aspects of water control, for instance with reference to the concept of 'landesque capital' (Blaikie and Brookfield 1987; Brookfield 2001), his contribution to the study of land has had a more enduring influence on rural development, environmental studies and political ecology. The focus on landbased issues has partially obscured a consideration of the role of water in society, yet water control is a key determinant in the process of agricultural intensification, and unequal access to water can be a significant factor in social differentiation.

This chapter seeks to address apparent 'water blindness' in rural development studies and political ecology by exploring the role that water control contributes to agricultural intensification. The concept of 'water blindness' was used by Malin Falkenmark (2001) to refer to the inability of those coming from technical disciplines to treat water problems within the totality of the hydrological cycle and engage with policy-makers. Here the term is used in a rather different sense, referring to the insufficient attention given to the role of water in rural development and political ecology literature. The chapter examines the recent history of water control in the Mekong Delta, Vietnam, and draws on key concepts developed by Brookfield in political ecology and in the explanation of land degradation and agricultural intensification, namely scale and landesque capital. The research presented here draws on fieldwork conducted in the Mekong Delta and elsewhere in Vietnam between 1995 and 2000. Although the land and its managers have been central to much previous analysis of agricultural intensification, here the analytical focus shifts from uphill-downhill interactions to upstream-downstream interactions. Water and its managers are thus brought from the margins and situated at the centre of the analysis of agroecological and social change in the Delta. 


\section{Political ecology, scale and water control}

Arguably the most influential texts in the evolution of political ecology were Blaikie's The Political Economy of Soil Erosion in Developing Countries (1985) and the later volume edited by Blaikie and Brookfield, Land Degradation and Society (1987). Environmental processes are there interpreted with reference to their broader historical and political economic context, taking into consideration dominant state ideologies, competing perceptions of resources, histories of colonialism, interests of local elites and the role (and partial perspectives) of foreign 'experts'. Blaikie and Brookfield discuss how an unbalanced approach to the role of geophysical or social processes in environmental change can result in erroneously identifying the causes of degradation and lead to inappropriate policy and project interventions. They argue that what is required is a recognition of the competing definitions of land degradation and a rejection of the search for a single 'scientific' definition of the problem (1987: 16). Thus land managers and their perceptions of problems should be 'centre stage' in any explanation of land degradation. By starting with the relations between land managers and land resources, and then exploring the relations between land managers and other users and social groups, including links with the wider society and the state, the broader context of society-land relations can be progressively analysed.

Scale relations are thus crucial to the study of land degradation, and to the interplay between resource users and broader political, economic and environmental processes. Scale is discussed at length by Blaikie and Brookfield in terms of core-periphery relations, the distribution of costs and benefits, and place and nonplace based processes. Its significance for land management is seen to rest upon, among other factors, an 'understanding about who, at what level, makes landmanagement decisions' (1987: 69) and how analysis at different scales influences the type of explanation given to environmental processes. They suggest:

a comprehensive enquiry into land management will require an approach which employs a nested set of scales: local and site specific where individuals or small groups make the relevant decisions; the regional scale involving more generalized patterns of physiographic variation, types of land use, and property relations and settlement history; the national scale in which the particular form of class relations gives the economic, political and administrative context for land-management decisions; and the international scale, which, in the most general manner, involves almost every element in the world economy, particularly through the commoditization of land, labour and agricultural production. How those pervasive processes of agrarian change impinge upon land managers at the local level is to some extent the result of a mediation through the state structure and the various interests which use and work through it.

(Blaikie and Brookfield 1987: 68-69)

Decision-making on water, like land, can be understood through exposition of scales of action and analysis. Yet contrary to the way scale is represented by Blaikie 
and Brookfield, Howitt $(1993,1998)$ argues that conceptualising scale in terms of a discrete nested hierarchy can obscure important interscalar linkages, and that representation of scale dialectically (rather than hierarchically) is more meaningful as it helps avoid deterministic notions of social processes and causation. Scale, rather than being fixed in space and time, is a fluid concept, influenced by the meanings attached to it by different actors. Scales are 'perpetually redefined, contested and restructured in terms of their extent, content, relative importance, and interrelations' (Swyngedouw 1997: 141). Such a fluid conception of scale, and scale politics, characterises contemporary approaches to political ecology.

Whilst only limited attention is given to water-related issues in the work of Brookfield, they are explicitly addressed in the concept of landesque capital: the diverse investments in water control that occur for the purpose of agricultural intensification, such as walls, terraces and irrigation systems. Landesque capital is the physical evidence of intensification, reflecting substantial labour inputs for both initial construction and subsequent maintenance. It is distinct from interventions in relation to a single crop, as it aims to have long-term benefits for securing future production. Whilst the concept was earlier interpreted primarily with reference to technical investments, Brookfield (2001: 184) has recently stressed the role of farmers' organisational skills and other diverse capital investments, arguing that such factors underpin the process of adaptation and innovation in agricultural change.

Blaikie and Brookfield observe that investments in landesque capital are rarely those of individual decision-makers, hence it is necessary to identify clearly the land manager(s) or hierarchy of managers involved in land management since 'managers may have different decision-making environments and different claims or demands upon the same tract of land' (1987: 8-9). As discussed in this chapter, explicit changes in the scale of decision-making on production have accompanied investment in different forms of landesque capital for water control in the Mekong Delta, with the state in particular playing a key investment role.

Perhaps in part due to the strong influence of Blaikie and Brookfield's formative work, scholarship in political ecology was subsequently largely concerned with studies of land-based issues, such as soil degradation, desertification, deforestation and agriculture. This 'water blindness' has, however, been partially redressed in recent years, with new research that explicitly applies a political ecology approach to the study of the institutions, discourses and ecologies of water, and the distribution of costs and benefits in water resources development (e.g. Donahue and Johnston 1998; Pelling 1999; Allan 2000). Derman observes that 'an examination of the history, discourse, economic, politics, and ecology of water is an excellent entry point for exploring the alignment of material interests in water allocation and distribution with the competing discourses about water'; the arena of water management 'constitutes a critical arena for understanding how scarce resources for development and environmental protection are being contested' (1998: 75). Moreover, water management reveals social and economic inequalities, as evident in changing relations of access and use over time. 
The remainder of the chapter applies the concept of landesque capital as it relates to the role of water control in agricultural intensification and explores the relationship between such investment and changing scales of resource decisionmaking in the Mekong Delta. Agricultural intensification in this dynamic and productive region is situated with reference to the broader historical context of changing society-water relations.

\section{Society-water relations in the Mekong Delta}

\section{The fluid geography of the delta}

I remember there was a really strong flood in 1978 and all the rice in this area died. Then in 1979 there was another flood, though not as bad as 1978. Then there was another one in 1983. So the government encouraged farmers to change from floating rice to two dry season rice crops because people kept losing their rice in these bad floods. The change to two crops in this commune coincided with the establishment of a collective. At first we didn't want to change because we were worried about the technology and the change from cultivating with the floods to cultivating in the dry season. But then the farmers realised it would be more convenient and produce more rice. At first the irrigation system and flood protection system were not very good and we only had very shallow ditches for irrigation and drainage. We faced many difficulties at this time, as we didn't know how to use fertiliser and pesticide, the equipment for land preparation and rice processing was not very good, and we had insufficient inputs.

(A farmer in Tam Nong district, Dong Thap province, 22 August 2000)

Forces of environmental change, whether seasonal, short term or long term, mean that variability and dynamism define the natural and physical environment of the Mekong Delta. Consequently, environmental change as the defining characteristic of people's livelihoods, whether brought about by human or environmental processes or both (as discussed by the farmer quoted above), has led to the development of adaptive technologies to cope with acute seasonal variations in water availability, the influence of saline water conditions and extensive flooding. Over time, responses to two key environmental risks have influenced agricultural intensification in the Delta: water scarcity, particularly saline intrusion; and water excess, or flooding.

Saltwater intrusion is a common, naturally occurring phenomenon of deltaic environments and has a distinct seasonal dimension, with its extent and duration largely determined by river flow and topography. As the flow of the Mekong River decreases at the end of the monsoon season, saline water begins to move landwards up the many natural and artificial channels. It can reach a distance of more than 60 kilometres inland (at a concentration of 3 grams per litre) along the main channels of the Mekong (Nguyen Thanh Tin and Ghassemi 1999: 26), affecting an area of 
up to 2.1 million hectares (or 53 per cent of the delta) in the lower delta for several months. Traditionally people did not cultivate rice during this period.

By contrast, floods severely affect the upper part of the delta, arriving each year in June to July. In the lower delta the floods have the effect of pushing saline water seawards, flushing the saline and acidic water from farmers' fields and canals. The risk of flooding is tempered by the natural regulation of river flows by the Tonle Sap Lake in Cambodia. Floodwaters can cover an area of 1.4-1.9 million hectares of the delta, for periods of $2-5$ months, reaching heights of up to 3 metres (VNMC and UNDP 1999: 15). The annual floods form a vital part of life in the delta, replenishing the fertility of aquatic systems and farmers' fields, with large floods often resulting in bumper crop yields and large catches of fish. The slow release or drainage of floodwaters also assists with agriculture in the coastal zone by delaying the onset of saline intrusion.

Whilst floods and the presence of saltwater have constrained agricultural intensification in the delta, the natural dynamism and variation in flows and nutrients of the Mekong River greatly contribute to the fertility and productivity of the delta. The delta became the 'rice bowl' for the country prior to the 1920s depression, and again following economic liberalisation accompanying doi moi (renovation) from the mid-1980s. Rice production from the delta has assisted Vietnam's transition from a situation of near famine in the 1970s to becoming one of largest rice exporters in the world today.

\section{Overview of water control in the delta}

Although the delta can be seen as a complete ecological system made up of interconnected components, the integrity of this system has been undermined over time through the impact of water control structures which divide, desiccate and compartmentalise wetlands, forests and grasslands. As the complexity and diversity of this ecological system has declined, water control structures have become more physically interconnected, integrated and complex. The methods used to temper and adapt to the seasonal extremes of water excess and water scarcity have transformed both the physical and social landscapes of the delta. With the construction of an increasing number of water control structures, production has changed from fairly individualised, extensive farming to more intensive, interdependent production, subject to greater collective constraints and interdependencies. Concurrently, decision-making on water, like the physical size of water control structures, has shifted to a greater scale. The risks of water scarcity and excess posed to farming systems have largely defined the trajectory of water resources development in the delta. Distinct phases in society-water relations are distinguished in the following sections of this chapter according key changes in water control infrastructure and technology, the dominant actors involved in decision-making and the scale at which decision-making occurs (Table 11.1). 
Table 11.1 Summary of water and agricultural transformations in the Mekong Delta

\begin{tabular}{|c|c|c|c|}
\hline & \multicolumn{3}{|l|}{ Time period } \\
\hline & $\begin{array}{l}\text { Nguyen/French: } \\
1600 \text { s/1860s-1954 }\end{array}$ & $\begin{array}{l}\text { RVN/US: } \\
1960 s-1970\end{array}$ & $\begin{array}{l}\text { S.R. Vietnam: } \\
1975 \text { to present time }\end{array}$ \\
\hline $\begin{array}{l}\text { General } \\
\text { characterisation }\end{array}$ & $\begin{array}{l}\text { Opening up the } \\
\text { Frontier }\end{array}$ & Modernisation & Rice Bowl \\
\hline $\begin{array}{l}\text { Socio-political } \\
\text { change }\end{array}$ & $\begin{array}{l}\text { Colonialism; } \\
\text { extractive economy }\end{array}$ & Neocapitalism & $\begin{array}{l}\text { National reunification; } \\
\text { socialist transformation; } \\
\text { economic renovation }\end{array}$ \\
\hline $\begin{array}{l}\text { Dominant } \\
\text { water actors }\end{array}$ & $\begin{array}{l}\text { Military, colonial } \\
\text { administration; } \\
\text { private entrepreneurs; } \\
\text { landlords }\end{array}$ & $\begin{array}{l}\text { International } \\
\text { consultants; } \\
\text { RVN government; } \\
\text { farmers }\end{array}$ & $\begin{array}{l}\text { International consultants; } \\
\text { national government; } \\
\text { water companies; } \\
\text { pumping-station } \\
\text { operators; pump owners }\end{array}$ \\
\hline $\begin{array}{l}\text { Water technologies / } \\
\text { infrastructure }\end{array}$ & $\begin{array}{l}\text { Canals; mechanical } \\
\text { dredgers }\end{array}$ & $\begin{array}{l}\text { Canals, low-lift } \\
\text { pumps, dykes }\end{array}$ & $\begin{array}{l}\text { Canals, pumping stations, } \\
\text { dykes and gates }\end{array}$ \\
\hline $\begin{array}{l}\text { Aim of water } \\
\text { resources } \\
\text { development }\end{array}$ & $\begin{array}{l}\text { Open up delta; } \\
\text { extend frontier; } \\
\text { strategic, military }\end{array}$ & Intensify production & $\begin{array}{l}\text { Continue intensification } \\
\text { and protect delta }\end{array}$ \\
\hline Water control & $\begin{array}{l}\text { On-farm water } \\
\text { control }\end{array}$ & $\begin{array}{l}\text { Some water control; } \\
\text { localised water } \\
\text { conflicts }\end{array}$ & $\begin{array}{l}\text { Barrier technology; } \\
\text { distributive effect; more } \\
\text { 'integrated' approach }\end{array}$ \\
\hline $\begin{array}{l}\text { Agriculture } \\
\text { characterisation }\end{array}$ & $\begin{array}{l}\text { Extensive; traditional } \\
\text { farming techniques }\end{array}$ & $\begin{array}{l}\text { Extensive, some } \\
\text { intensive; traditional, } \\
\text { integrated farming } \\
\text { systems, Green } \\
\text { Revolution technology }\end{array}$ & $\begin{array}{l}\text { Intensive; double, triple } \\
\text { cropping, agrochemicals }\end{array}$ \\
\hline Land relations & Large concessions & Land reform & $\begin{array}{l}\text { Collectivisation; } \\
\text { decollectivisation }\end{array}$ \\
\hline $\begin{array}{l}\text { Scale of } \\
\text { decision-making }\end{array}$ & $\begin{array}{l}\text { Local plus macro } \\
\text { players }\end{array}$ & $\begin{array}{l}\text { Local plus macro } \\
\text { players }\end{array}$ & $\begin{array}{l}\text { Local, shift to collective, } \\
\text { shift to macro }\end{array}$ \\
\hline Approach to risk & Adaptive & Transition & Command and control \\
\hline
\end{tabular}

\section{Opening up the delta: the role of colonial canal building}

\section{Large-scale settlement and agricultural expansion in the delta}

The landscape of the delta had already been criss-crossed with the lines of humanmade canals dug (and re-dug) during the Funan, Angkor and Nguyen periods, before the era of French machine-made canals further dissected the delta floodplain. The application of this technology and the mobilisation of labourers under the corvée system allowed the French to extend and consolidate the earlier canal system. The lines of the canals contrasted with the more organic, shifting shapes of 
the rachs (impermanent tidal stream), arroyos and other natural waterways that make the boundary between land and water indistinguishable in this 'amphibious' landscape (Brocheux 1995).

Following the construction of the main canals, settlers, usually tenants under contract to landlords, established farms with little further assistance or organised public works:

once the main canals were dug, each field could be improved independently of any other so that the exploitation of the Lower [Mekong] Delta required neither central planning and organization nor a large permanent labor force. Thus, unlike the situation in the Red River Delta where the individual or even the household had to belong to a large social unit in order to successfully exploit the environment, in the south, homesteading of the newly opened expanses of the West [of the delta] by individual nuclear families moving and working as autonomous units was feasible.

(Rambo 1973: 64-65)

Elements of this independent, pioneer spirit persist, influencing relations in local water management. Private interests played an influential role in determining the location of water infrastructure and in the canal construction. Central and provincial authorities oversaw the construction and maintenance of the main canals, with farmers and landlords primarily responsible for tributary and on-farm channels.

The area under rice cultivation and population in Cochinchina both increased rapidly, reaching some 2.2 million hectares and 4.5 million people by 1937 (Robequain 1944). The canals and reduction in forest area greatly modified the distribution of water throughout the delta, resulting in a new spatial distribution of floods and saline water. Farmers were impelled to draw on their own ingenuity to cope with these risks, developing adaptive agricultural technologies and production regimes uniquely suited to the alternating wet and dry seasons and to the water and soil conditions.

\section{Adaptive farmers: 'shaking hands with the flood'}

The adaptive and flexible approach developed by farmers to the environmental risks of flooding and water scarcity is reflected in the local saying 'shaking hands with the flood', which indicates a perspective of acceptance rather than resistance to potentially catastrophic risks (Nguyen Huu Chiem 1994). The gradually rising and falling Mekong flood regime permitted cultivation of floating and deep-water rice in the floodplain of the upper delta. Field bunding under this farming system was primarily for cadastral purposes rather than for water control and, with limited land preparation required, labour inputs were very low. In the shallow flooded, tide-affected zone of the mid delta, farmers grew double-transplanted deep-water rice, appropriate to the local flood and tidal regime. In the lower delta single transplanted rainfed rice was cultivated in areas not subject to severe flooding. Rice was sown with the rains, transplanted and harvested prior to the onset of water 
scarcity and potential saline period. Rice was, and continues to be, supplemented by fishing activities, the harvest of plants from forests and wetlands, and the cultivation of upland crops in the dry season (Nguyen Van Sanh et al. 1998; Miller 2003). The continuing importance of fish to local livelihoods in the deeply flooded zone of the upper delta is apparent in the way farmers interviewed in Dong Thap province in 2000 variously refer to the division of their time between six months for fishing (during the floods) and six months for rice (during the dry season).

Traditional varieties of rice used in such systems have lower yields than modern high-yielding varieties (HYVs), but they have key environmental advantages. Farming systems practised in the mid to upper delta are well suited to the annual cycle of floods, rains and seasonal water excess, reliant on the flood's silt and nutrients to maintain soil fertility, whereas farming systems in broad depression area are adapted to water scarce and brackish conditions.

\section{Investment in agriculture, scale of decision-making}

During the French colonial period, apart from public investment in the construction of large canals and the initial clearing of agricultural land by settlers, investment in agriculture was strictly curtailed by wider political and economic circumstances. A primary reason for the limited investment in agriculture was the exploitative nature of the economy, which existed under landlord capitalism. A socially regressive and unequal land holding pattern was established, dominated by large farms run predominantly by French and Sino-Viet landlords and worked by tenant farmers. There was no 'owner-tiller' tradition and little communal land in the delta, unlike other parts of Vietnam (Pham Cao Duong 1985; Brocheux 1995). The level of landlessness was very high, with more than 50 per cent of cultivable land concentrated in the hands of less than 3 per cent of the population (NDDT and Mekong Committee 1994: 30). The French geographer Pierre Gourou (1947), commenting in the 1940s on the scale of organisation of farming in Cochinchina, observed that even amidst quite large landholdings the method of farming was similar: basically that of small-scale exploitation, carried out by the cultivator and their family.

Although regulation of water was primarily at the farm level under this smallscale farming, decision-making power and the control of economic resources were held by landlords and colonial authorities. The pattern of land allocation and structure of the economy resulted in a highly polarised distribution of wealth. Benefits of economic growth were largely inaccessible to the majority of labourers, peasants and small landholders, with only a few large landlords, Chinese traders and French capitalists and colonists benefiting from the liberal plantation economy (Scott 1976).

Canals played an important role in opening up the delta to the international economy, with rice exports from the delta rising to over a million tonnes by 1928 . Yet rice exports from Cochinchina were hit badly by the depression and from competition from higher quality rice from elsewhere. The increasing number of absentee landlords from the 1930s onwards meant it was difficult for tenants to mobilise to improve production or local irrigation work, as they lacked the economic and political resources to mobilise to invest in landesque capital. 
The situation in the delta in the 1930-40s was 'one of a fixed land frontier, static techniques of production, unchanging market opportunities, and a high rate of population growth' (Sansom 1970: 25). Intensification and improvements in yield accounted for subsequent increases in production as land clearance options diminished. With the land frontier nearly exhausted by the end of the colonial era, a different orientation in water resources development was to emerge. Just as canals were crucial to the process of extensive agricultural development, so new forms of water resource development and an increase in investment in landesque capital was to become crucial to agricultural intensification from the 1960s onwards.

\section{Green Revolution in the delta: the neocapitalist era}

The Mekong Delta was a crucial military battlefield in the Indochina Wars, and in the post-1975 environment it formed an ideological battlefield between socialist economic policy and local capitalist activity. Key changes in agriculture and water control were to occur in the delta during the neocapitalist era of the Republic of Viet Nam (RVN) (1954-75) and later during the post-1975 period of 'socialist transformation'. The introduction of new technologies, redistribution of the means of production and a change in the scale and purpose of water resources development transformed the way water was perceived, valued and used in the delta. External actors, such as the United States, were crucial in this transformation, projecting their particular resource ideologies onto the delta landscape.

\section{Technological developments and landesque capital}

The orientation of agriculture shifted from extensive to intensive production as new technologies were introduced, such as HYVs, chemical fertilisers, mechanised land preparation, low-lift mechanical pumps and pumping stations. Associated with this technology was an increase in investment in landesque capital, with the orientation of hydraulic works changing towards irrigation development, flood protection and salinity intrusion control. Consequently double cropping began to expand throughout the mid to upper delta, resulting in a decline in traditional farming systems and local rice variety diversity.

The introduction of Green Revolution technology to the delta was part of US efforts (as the key ally of the RVN) to promote 'modernisation' of the South Vietnamese economy. Brookfield and Blaikie, in discussing scale and decision-making in land management, observe that a different form of control over management accompanied the Green Revolution in Asia, as the introduction of new varieties of plants and subsidised fertiliser removed management to higher levels (1987: 80). Qualitatively different decision-making structures also concerning water accompanied Green Revolution changes.

\section{Redistribution of resources, increased investment in irrigation}

Together with technological and infrastructural changes, land reforms resulted in a redistribution in the ownership of the means of production. In Viet Minh- 
controlled areas land was redistributed to tenants towards the end of the First Indochina War. These gains were later effectively reversed under the land reforms of the Diem regime (Beresford 1989: 95). However, following the Tet Offensive and growing rural unrest, a major land-reform program known as 'Land-to-theTiller' was implemented, resulting in the partial dismantling of the landlord system in areas previously unaffected by Viet Minh reforms.

Land reforms resulted in key changes in irrigation and drainage development in some parts of the delta. First, the few remaining landlords demonstrated some social responsibility and invested in local irrigation developments (Sansom 1970: 154). Second, farmers freed of crippling debts, rents and taxes were able to invest in land and production improvements. Subsequently, several medium scale watercontrol projects were constructed in strategic locations in the delta, with the assistance of US aid funds. The low-lift water pump was widely adopted throughout the delta from the early 1960s. The pump saved labour, allowed land to be double cropped, substituted capital for land and allowed an extension of the cropping season (Sansom 1970; Miller 2003). Those who could not afford such an investment hired pumps from their neighbours or local entrepreneurs. Though most delta farmers now own pumps it is still common for people to enter into rental arrangements to gain access to them.

\section{Shift in scale of water resources planning}

One of the most significant transformations in society-water relations in the RVN period was the shift in scale of water resources planning to the delta as a distinct unit. With the assistance of the Mekong Committee, and with US and Dutch aid and expertise, a number of macro-level studies were conducted into the development potential of the delta's water resources. This was a departure from previous ad hoc, spatially fragmented, single-sectoral approaches. Although these plans were never realised during the RVN period, with water resources development continuing to be fragmented and disconnected until the mid-1990s, the plans were significant in their implications for subsequent water resources development.

In the late 1960s US President Johnson commissioned the chief architect of the Tennessee Valley Scheme, David Lilienthal, to investigate how water resources development could contribute to the development and thus 'pacification' of the delta (Nguyen Thi Dieu 1999). Lilienthal saw water control as central to agricultural development, stating:

The basic problem inhibiting the growth of agricultural production in the delta may be stated in very simple terms: the delta farmer is unable to control the application of water to his [sic] crop. It is a tribute to his resourcefulness that he is able to wrest a livelihood from his land under the wide variations in water conditions which exist.

(Joint Development Group 1970: 523)

Agricultural development was seen as a technical matter, requiring engineering interventions. The Mekong Delta Development Program, developed by Lilienthal 
and his team, recommended a multipurpose, integrated approach based on flood protection, improved drainage, salinity control, irrigation and water transportation (Development and Resources Corporation and RVN 1969: 1). This included the proposal to close off the delta; it was argued that for agricultural development to be achieved a water control system should:

seal off the agricultural lands of the delta from floods, from high river stage, from the tides, and from the encroachment of salinity; and to control the ingress and egress of water to and from these sealed areas as required to provide for the four basic water control needs [of drainage, flood control, irrigation and salinity intrusion].

(Joint Development Group 1970: 524)

This plan was purposefully oriented to the macro scale, and provides a classic example of the technocratic orientation of water resources development at the time in terms of the dominance of large-scale regulatory structures, the 'command and control approach' to rivers and the disregard for the environment and local resource users' own development aspirations. The macro spatial scale of analysis and intervention produced a set of plans which profoundly neglected the long-term ecological and social impacts of engineering the water of the delta.

The adoption of such a macro view obscures the various ways in which microecological niches, subtle physical variations, local settlement history and cultural diversity combine to determine society-water relations at a local scale. At this local scale environmental impacts associated with engineering the delta landscape, such as the loss of subtle environmental gradients, species decline due to in-stream barriers, and floodplain and estuary ecosystem disturbances, can be clearly observed. The human dimension of such environmental changes includes loss of fish as a source of livelihood and the decline in water quality associated with increased use of chemical inputs that accompany the agricultural intensification. The implications of intensification for local fish populations, from increased chemical use and canalisation, are captured in the perceptions of one farmer from a part of the delta seasonally influenced by brackish conditions:

There are no fish in the local river any more because of the increased use of pesticides and loss of riverside vegetation. Previously there were heaps of fish but now the environment has changed so much that no fish come here anymore. People have been using pesticides for many years, however, one particular pesticide has had a devastating impact on the fish. It was used a lot last year and this has killed the fish and eels in the waterways. Now people are going to have to raise the fish themselves in their own ponds or buy them in the market.

(Interview with farmer, 7 December 2000)

Other delta-wide investigations were conducted following Lilienthal's Plan, however the proposed development projects were not implemented before the 
Communist victory in 1975. The subsequent international isolation of Vietnam meant it was cut off from any major international development assistance. A difficult economic period followed as a socialist development strategy was imposed on the delta, on a society and economy familiar with capitalism since colonial times.

\section{Socialist transformation: collective approach to land and water}

\section{State prioritisation of irrigation and investment in water control}

The new Hanoi government of 1975 faced enormous challenges for national reunification, economic reconstruction, food security and the generation of foreign earnings. The socialist transformation of society and the economy had been occurring in northern Vietnam since 1954, but it had only occurred in localised areas in the south. Irrigation held a special place in socialist agriculture, being seen as crucial in promoting collective modes of production and cooperation. The Vietnamese Communist Party leadership prioritised collectivisation and largescale irrigation works:

[s] ince irrigation was the pre-condition for such intensification of agricultural techniques, the organisation of labour by the State for larger works and on a collective basis for smaller schemes was seen in 1975 as the only means whereby the foundation could be laid for the building of 'large scale socialist production' throughout the country.

(Beresford 1989: 103)

A clear hierarchy of responsibility for water resources planning and management was established: national and provincial government was responsible for main waterways and primary canals; district level government for secondary (lateral) level canals; and farmers, under the direction of the commune, were responsible for the tertiary level system. Top-down relations between these scales of management were established, with little to no opportunity for local water users to influence decision-making at higher scales - a continuing feature of water resources management in Vietnam.

Water resources development became, unlike in previous eras, a purposefully public affair under the Ministry of Water Resources, and state-owned enterprises (SOEs). The scale of key aspects of decision-making on water shifted from the onfarm level to the scale of collective and district, and though collectivisation was strongly resisted in the delta, this shift in the scale of decision-making had much to do with physical changes in water control.

Irrigation expansion for rice in the delta was strongly pursued by the national government. Between 1976 and 1989 state investment in water resource development averaged around 62 per cent of total investments in agriculture. Much of this was in the Mekong Delta (Figure 11.1), with the construction of isolated flood and salinity intrusion control systems resulting in water control being generally 


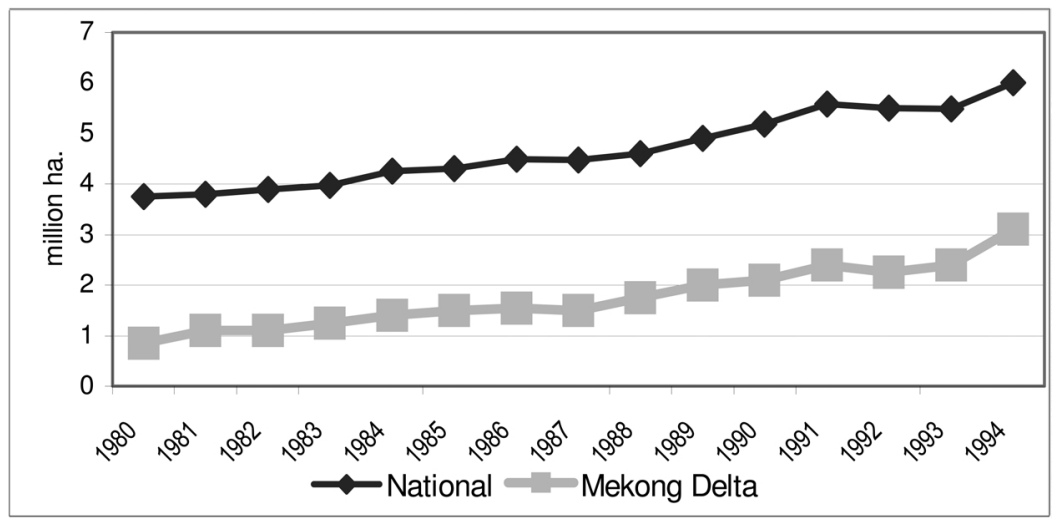

Figure 11.1 Irrigated rice area, Vietnam and the Mekong Delta, 1980-94.

practised at a secondary unit level (500-1,000 hectares) (NEDECO 1991b: 7). Flood control in the upper delta involved the building of polder areas protected by secondary level dykes, with water usually supplied by collective-operated pumping stations. Water control projects in the saline-affected part of the delta sought to extend the cropping season through salinity control, which involved the construction of dykes, earthen weirs and/or sluice gate schemes, with water regulated by the tide, gates and pumps.

\section{Collective scale of decision-making}

The state played a dominant role in investment in diverse forms of landesque capital throughout the delta, to promote agricultural intensification and collectivisation. Farmers were also mobilised to dig canals and other water control infrastructure (Miller 2003). These water resource development schemes assisted with the expansion of double cropping. Concurrently, unsuccessful attempts at collectivisation sought to shift decision-making authority on agriculture and water control from the on-field, household scale to that of the collective or cooperative. This shift in control of water resources was encouraged by the creation of physically discrete water control units, such as polder systems, irrigation areas and saline intrusion control schemes.

From the early 1960s significant physical and political changes occurred in the delta to affect the way water was used and accessed. As the physical landscape changed, and human regulation of water regime throughout the delta increased, so the social landscape also changed.

\section{Closing off the delta}

Increasing agricultural intensification in the delta followed the transformation of delta agroecology through the construction of thousands of kilometres of canals, 
and the closing off of the delta through water control structures, which regulated the timing and distribution of water. ('Closing' refers to the context where the flow of water at intake and outflow points is no longer wholly subject to natural flow variations, but is regulated with gates, pumps, dams and weirs.) Just as the creation of discrete water control units at a local level has created new challenges for cooperation between neighbours and communities, so closing the delta at a macro scale presents new challenges for water management institutions at this scale and for relations between scales. The following section discusses subsequent trends in agricultural intensification and water resources development in the delta, and the eventual realisation of delta-wide water resources development plans identified more than 30 years ago.

\section{Rice intensification and rise in zater demands}

Until the 1990s there was little large-scale flood protection in the delta. Water control projects were largely disconnected from each other, and planned and operated independently of other projects, even those in the same province. The flow of water throughout the delta remained largely naturally regulated and subject to the seasonal rhythms of the rains, floods and tides. Primary and secondary canals almost always had open connections, with connections between the primary canals and the river and the sea also open (NEDECO 1991b: 8). This gradually changed, with more in-stream barriers to obstruct or control the flow of water.

Delta farmers were very responsive to the doi moi reforms of the late 1980s. Key reforms included the formal recognition of household production, loosening of state controls on rice prices and a rise in private entrepreneurship. Double and triple cropping spread, accompanying the extension of the canal and water control system (Figure 11.2). Crucially, these changes were reliant on increased abstraction of dry-season flows, as seen in the increase in dry-season winter-spring (Dong-Xuan) crop cultivation during this period (Figure 11.3). Winter-spring and summer-autumn rice production increased in the order of 300 per cent in the 1980s (NEDECO 1991a: ix), and continued to rise in the 1990s.

A significant increase in intensive production throughout the delta has occurred since 1990 (Table 11.2), and between 1990 and 2010 the dry season water demand (January-June) is expected to increase from an estimated 9,300 to 16,460 gigalitres.

Such changed policies and land uses saw the irrigated area rise to 2.5 million hectares, resulting in a dramatic increase in rice production (according to official statistics) from 4.6 million tonnes in 1976, to 9.6 million in 1990 and 17 million in 2002 (Miller 2003), alongside much hyperbole over this growth and the status of the delta as the national 'rice bowl'. However, the transformation of the physical and social landscape of the delta involved greater inequality and new economic, social and environmental risks. Not all farmers benefited from increased rice production, evident in the rising level of landlessness, which was recently estimated to be about 21 per cent (World Bank 1999b). 


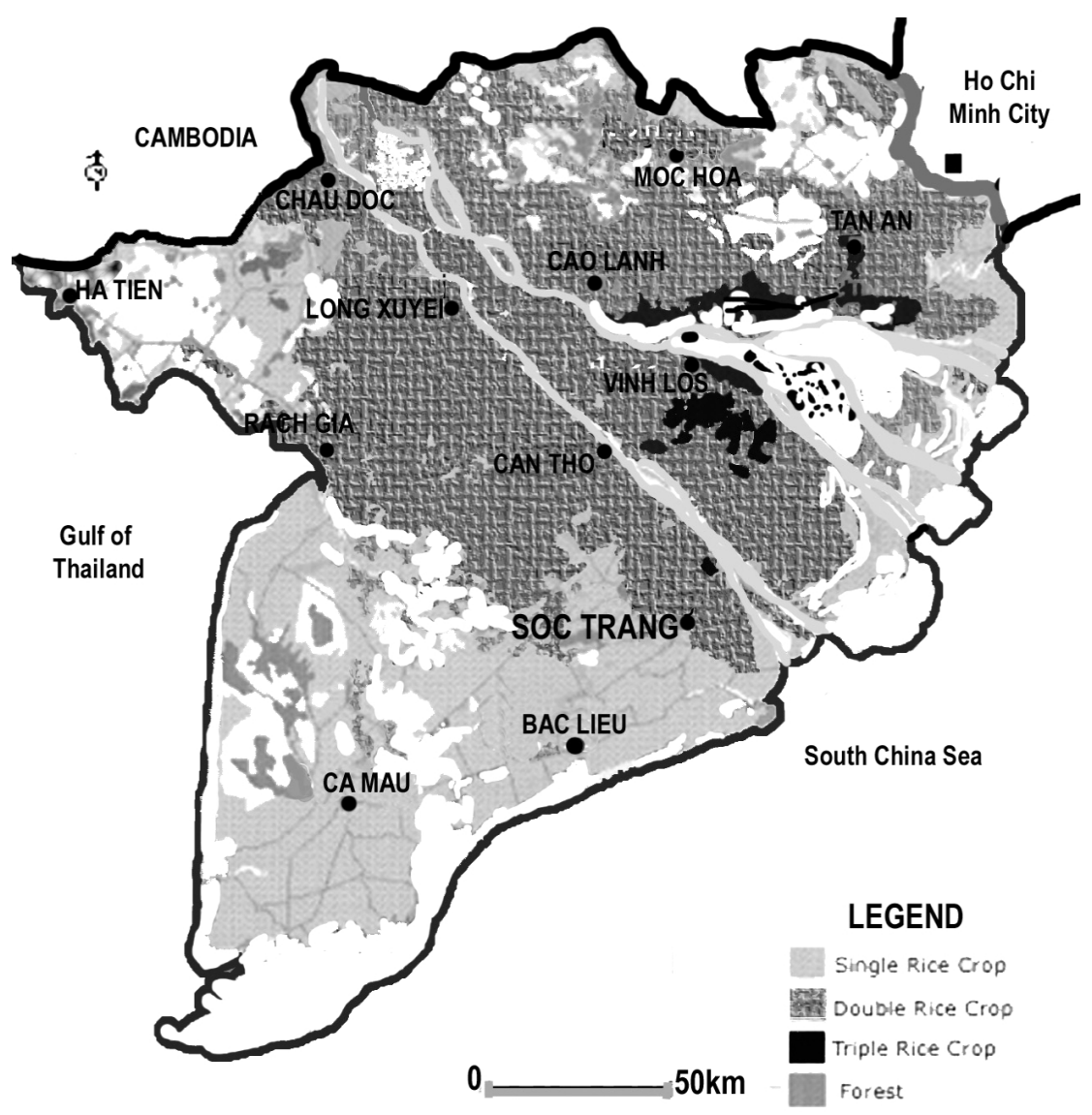

Figure 11.2 Land use in the Mekong Delta.

Table 11.2 Changes in land use in the Mekong Delta, 1990-2000

\begin{tabular}{lrrrc}
\hline $\begin{array}{l}\text { Land use } \\
\text { ('000 ha) }\end{array}$ & 1990 & 1996 & 2000 & $\begin{array}{l}\text { Percentage } \\
\text { change }\end{array}$ \\
\hline $\begin{array}{l}\text { Triple rice crop } \\
\text { Double rice crop }\end{array}$ & 97 & 277 & 248 & +151 \\
Single rice crop & 718 & 1,040 & 1,209 & +226 \\
Vegetables & 141 & 567 & 485 & -233 \\
Horticulture & 355 & 193 & 134 & -7 \\
Surface water & 162 & 203 & 368 & +13 \\
Total & 2,416 & 2,645 & 2,620 & +204 \\
\hline
\end{tabular}

Source: VNMC and UNDP (1999): 56. 


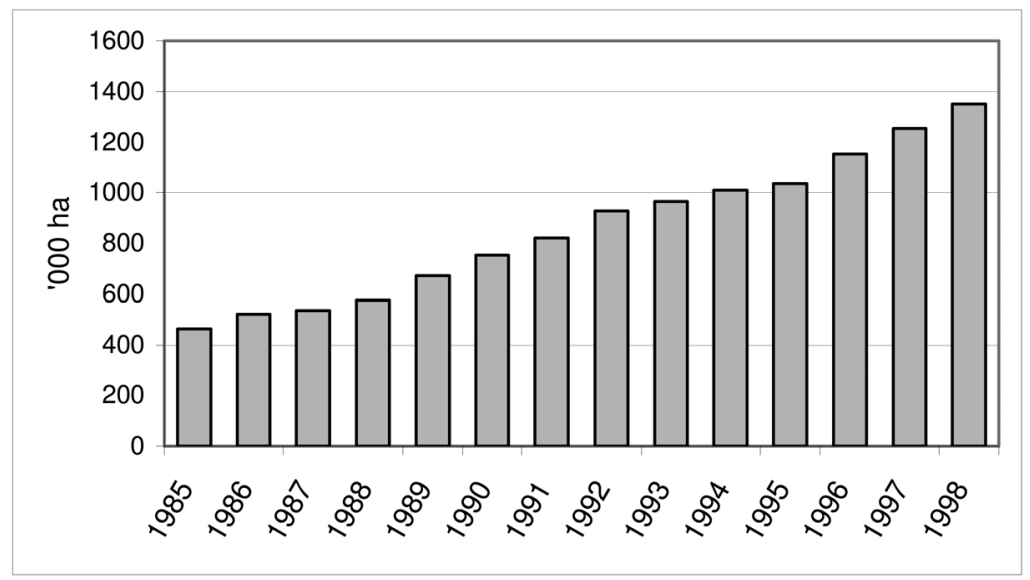

Figure 11.3 Winter-spring crop areas, 1985-98.

\section{Realising plans to close off the delta}

Authors of the Mekong Delta Master Plan observed in 1991 that '[f]ear of increased saline intrusion as a consequence of higher rates of abstraction of low flow ... has governed development planning [in the delta] to date' (NEDECO 1991a: 4). With the continued expansion of dry season rice cultivation in the upper and mid delta, and the prospect of upstream developments in the Mekong Basin putting greater pressure on dry season flows entering the delta, the need to protect the delta from worsening salinity took on greater national importance. A rise in the incidence of severe floods in the 1990s prompted the increased investigation of and investment in flood control measures. Achieving the triple goals of further intensification of rice production, closing off the delta to salinity intrusion and defending it from floods came to define the orientation of water resources development in the delta in the mid-1990s. Water resource developments now being realised in the delta have existed since the delta-wide studies of the 1960s. Although these plans have scarcely changed since then, they are now cloaked in the language of 'sustainability'. This engineering approach to agricultural development has come to dominate development strategy for the delta, with little attention given to other more locally defined strategies based on agricultural diversification and traditional integrated farming systems.

Closing off the delta required massive national investment of funds. In 1999 the World Bank approved funding of US\$148 million for the Mekong Delta Water Resources Project, the objective of which was to increase multiple cropping to 'maximise land usage' and agricultural production through irrigation improvement, drainage, flood protection and salinity intrusion control. Essentially this involved the conversion of (the little remaining) ecologically sensitive, seasonally influenced saline and brackish water affected areas into permanent freshwater areas. This required the rehabilitation and expansion of canals and development of 


\section{Fiona Miller}

salinity intrusion protection infrastructure along the coast. Freshwater was to be supplied from intake points further upstream on the main branches of the Mekong River (World Bank 1999a).

In addition to the World Bank project, the national government is investing more than 8.2 billion dong (US\$750,000) in partial flood protection in the upper delta and full flood protection in the shallow flooded mid delta through the construction of dykes and floodgate systems (SIWRP 1997; Figure 11.4). Water resource development plans for the delta until 2010 emphasise an extensive gateand-dyke system to close off the delta, while the increased role played by barrier technology in the regulation of water throughout the delta has raised new challenges for institutional cooperation and management, both within and between scales.

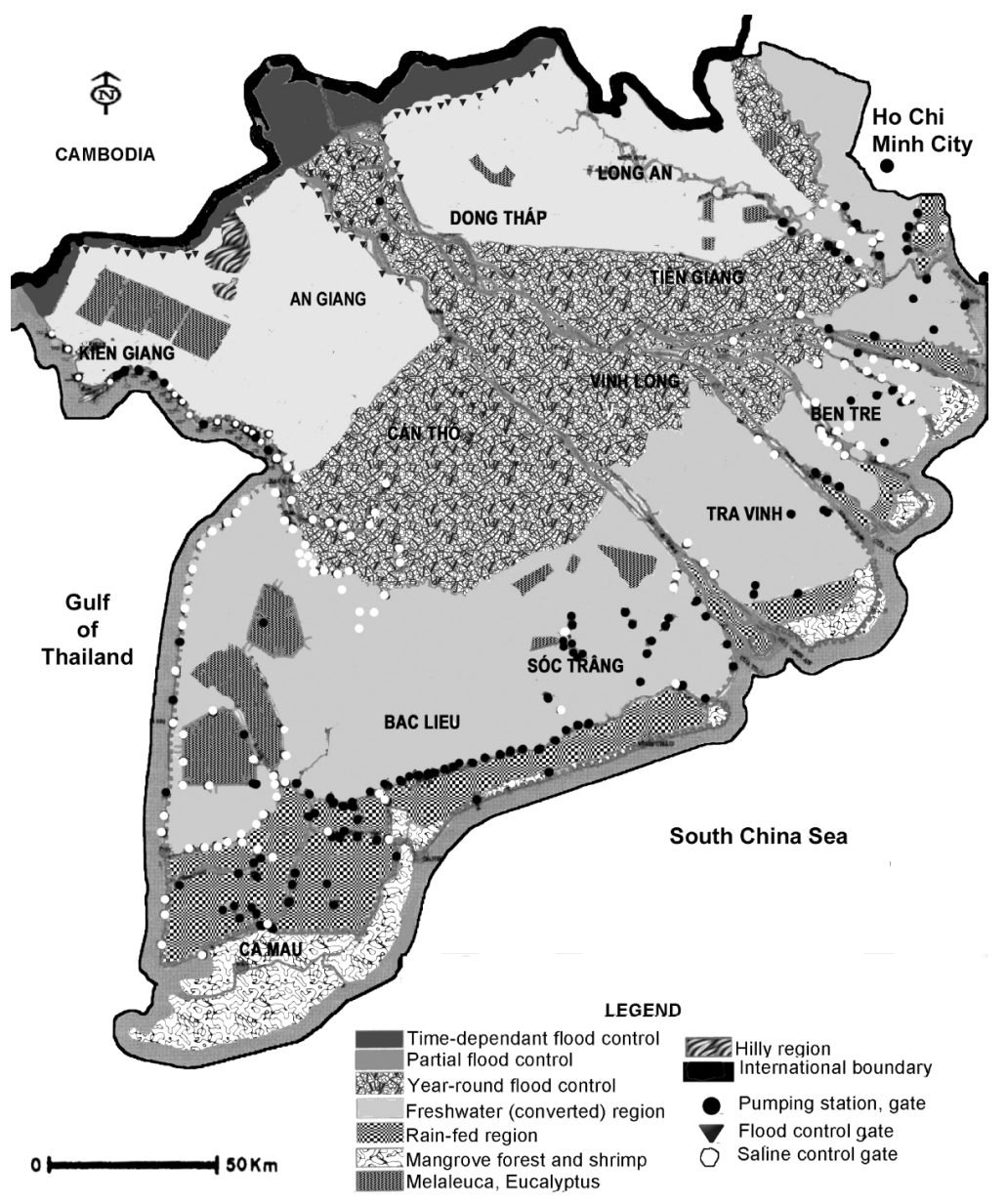

Figure 11.4 Planned water resource development in the Mekong Delta. 


\section{Competition and cooperation over water}

Closed water control systems and intensive agricultural production have increased the interdependencies between people in such matters as water access, system maintenance and cropping calendars. New tensions now exist between individualcollective interests, upstream-downstream users and the different scales of water management through which the responsibilities are distributed. Current tensions in water management and the complex ways in which people must now interact and negotiate with neighbours and other levels of management to drain and irrigate their fields are evident at the village level. For example, water control now being conducted at greater scales has necessitated cooperative and collective decision-making on land and water use, and likewise common cropping calendars among those within a single water control unit (as well as between different water control units). This is complicated by farmers being reluctant to follow officially recommended cropping calendars due to their independent farming traditions and the non-inclusive processes through which official calendars are determined.

Mechanisms for community-level water management are highly variable in both form and effectiveness, due to socio-cultural and agrohydrological diversity in the delta. In some localities water management is incorporated into the activities of recently established farmer groups or economic cooperation groups (which are more or less designed according to local water control units). One of the primary responsibilities of these groups is to organise and supervise farmers to maintain the tertiary canal system and coordinate cropping calendars. Elsewhere in the delta new cooperatives have been established which, alongside providing agricultural services, have responsibility for organising and supervising tertiary system maintenance and operation and also for negotiation of water service contracts (for example with private pumping stations) on behalf of cooperative members. Yet farmers are reluctant to both cooperate and maintain the tertiary (farmer) level system. The general deterioration of the irrigation system and poor quality of water services provided by government water management authorities and state owned enterprises provide a powerful disincentive for farmer action and cooperation. In one commune many tertiary and secondary canals were severely silted-up due to lack of maintenance and most sluice gates on the secondary canals were not operational, thus restricting water access.

Despite a long tradition of collective action in the Mekong Delta, most obviously seen in the mobilisation of relief efforts during frequent severe floods, farmers generally remain reluctant to cooperate in agricultural activities and water matters. This reluctance is a legacy of forced collectivisation during the late 1970s and early 1980s, and the long tradition of independent farming practices and individual commercial relationships. These factors have combined with the limited capacity, though often well-meaning intentions, of local officials in facilitating participatory decision processes to produce mixed success in the establishment of cooperative water management mechanisms at the community level.

Competition is now apparent between water users in single water control units - with cooperative mechanisms generally unable to address this competition - the 
origin of which lies in water scarcity, conflicting cropping calendars or production systems, conflict between agricultural activities, fishing activities and other uses of local waterways (such as transportation) and the environment, as well as the unequal water access arrangements which result from poor system design, maintenance and operation. The continued absence of a well-developed tertiary level system has resulted in a high percentage of indirect water access arrangements in certain localities. For example, in a commune of Chau Thanh district, Tra Vinh province, close to half of the 73 people interviewed reported indirect water access to be a problem (Miller 2003). Greater water scarcity in the delta, combined with increasing rural population densities and the intensification of production systems, means water has become an even more critical factor of production. Unequal access to water, now apparent at a local level, has the potential to further exacerbate local inequalities and agrarian differentiation due to the higher costs incurred by those with poor or indirect access, and the reduced yields which result from inadequate water application.

\section{Conclusion: towards a political ecology of water}

This analysis of the role of water resources development in agroecological change in the delta has shown that digging thousands of kilometres of canals resulted in the opening up of the delta to the flow of water, goods and people. These canals provided the infrastructural foundation for an outward-oriented rice export economy. During the RVN era, Green Revolution technologies were introduced and US and Dutch engineers drew up large-scale development plans for the delta. These plans were resolutely technocratic in orientation, and were dominated by engineering aims with little regard for ecological impacts on the dynamic, interconnected delta ecology. After 1975, fragmented water control efforts occurred under a socialist economic orientation, but it was not until the mid-1990s that plans to close off the delta and invest in large-scale flood protection and salinity intrusion control works were realised.

This analysis of multiscale changes has revealed several shifts in regards to society-water relations in the delta: first, transition from a fairly open, naturally regulated water regime to a closed system, where human regulation of water has taken on greater importance with the construction of complex regulatory structures; second, transition in production from fairly extensive farming systems adapted to the seasonal variability and availability of water to more intensive production systems reliant on the precise control of water and increased dry season water consumption; third, transition in the scale of water management as the physical size of water control units and planning has increased, resulting in a scaling up of water control functions and planning from the on-field scale to greater scales. This has occurred in the absence of any effective mechanism for local water users to influence decision-making at these more macro scales.

As structures for human regulation of water have increased, the nature of production has also changed, from fairly individualised, independent farming to farming now subject to greater interdependencies and coordination of water use. 
The construction of a vast water control system has institutional implications, as all these structures require maintenance, operation and a socially acceptable distribution of water. Farmers in the delta have, for cultural and political reasons, resisted a shift towards greater collective decision-making. Contradictions now exist between the direction of national policy trends associated with doi moi, towards greater individual autonomy in production-related matters, and the social implications associated with physical changes in water control which have increased interdependencies between individuals and communities in order to gain access to common water resources.

Water control is central to agricultural intensification in the Mekong Delta, and investment in landesque capital affects the scales of decision-making. With the increased human regulation of the water regime, institutional issues associated with water allocation and resolution of water conflicts have increased in importance. As demand for water has increased with greater agricultural intensification, the impact of water scarcity on production activities has been magnified due to the precise water requirements of modern rice varieties. Institutional innovation is likely to occur as communities are confronted with challenges associated with the distribution of an increasingly scarce resource under intensive production regimes. How institutions distribute this scarce resource (spatially and socially) in the future will greatly determine the sustainability of development.

By considering the broader historical, economic and political context of resource use, a clearer understanding of environmental change emerges. A focus on the single resource of water and its role in rural development provides a historically informed analysis of the changing discourse of development, and it reveals how different actors have sought to leave their mark on the 'waterscape'. Just as Brookfield's focus on land has contributed to our understanding society-environment relations, a focus on water reveals broader economic and political processes, and diverse and competing interests. Considering the essential nature of water in ecosystem functioning, daily life and production activities, it is surprising that early studies in political ecology gave it less attention. This early 'water blindness' in political ecology, however, is now being redressed, in part because of critical water shortages. As water scarcity, in both absolute and relative terms, becomes a more common feature of daily life throughout many parts of the world, how society addresses issues of access to water and its allocation to social groups, economic sectors and the environment will become an increasingly critical issue in development.

\section{References}

Allan,J A (2000) Contending environmental knowledge on water in the Middle East: global, regional and national contexts, in P Stott and S Sullivan (eds), Political Ecology: Science, Myth and Power, London: Arnold, pp. 117-31.

Beresford, M (1989) National Unification and Economic Development in Vietnam, Basingstoke: Macmillan.

Blaikie, P (1985) The Political Economy of Soil Erosion in Developing Countries, London: Methuen. 
and Brookfield, H (1987) Land Degradation and Society, London: Methuen.

Brookfield, H (2001) Intensification, and alternative approaches to agricultural change, Asia Pacific Viewpoint, 42, 181-92.

Brocheux, P (1995) The Mekong Delta: Ecology, Economy, and Revolution, 1860-1960, Madison, WI: University of Wisconsin Press.

Derman, B (1998) Balancing the waters: development and hydropolitics in contemporary Zimbabwe, in J Donahue and B Johnston (eds), Water, Culture and Power: Local Struggles in a Global Context, Washington DC: Island Press, pp. 73-94.

Development and Resources Corporation and Republic of Vietnam (RVN) (1969) Appraisal Report Mekong Delta Development Program, New York: Development and Resources Corporation.

Donahue, J and Johnston, B (eds) (1998) Water, Culture, and Power: Local Struggles in a Global Context, Washington DC: Island Press.

Falkenmark, M (2001) The greatest water problem: the inability to link environmental security, water security and food security, Water Resources Development, 17, 539-54.

Gourou, P (1947) Les Pays Tropicaux, Paris: Presses Universitaires de France.

Howitt, R (1993) 'A world in a grain of sand'. Towards a reconceptualisation of geographical scale, Australian Geographer, 24, 33-44.

(1998) Scale as relation: musical metaphors of geographical scale, Area, 30, 49-58

Joint Development Group (1970) The Postwar Development of the Republic of Vietnam - Policies and Programs, New York: Praeger.

Miller, F (2003) Society-Water Relations in the Mekong Delta: A Political Ecology of Risk, unpublished $\mathrm{PhD}$ thesis, School of Geosciences, University of Sydney.

NEDECO (1991a) Mekong Delta Master Plan, Bangkok: Government of Vietnam/State Planning Committee/ World Bank/ Mekong Secretariat/ United Nations Development Programme.

-(1991b) Mekong Delta Master Plan - Working Paper No. 1 Surface Water Resources and Hydraulic Modelling - Volume 1: Main Text. Bangkok: Mekong Secretariat.

The Netherlands Delta Development Team (NDDT) and Mekong Committee (1994) Recommendations Concerning Agricultural Development with Improved Water Control in the Mekong Delta, Bangkok: Committee for the Coordination of Investigations of the Lower Mekong Basin.

Nguyen Huu Chiem (1994) Former and Present Cropping Patterns in the Mekong Delta, Southeast Asian Studies, 31, 345-84.

Nguyen Thanh Tin and Ghassemi, F (1999) Availability and Quality of Surface Water Resources An Evaluation for the Sustainability of Farming Systems in the Brackish Water Region of the Mekong Delta. Ho Chi Minh City: ACIAR.

Nguyen Thi Dieu (1999) The Mekong River and the Struggle for Indochina: Water, War and Peace, Westport, CT: Praeger.

Nguyen Van Sanh, Vo Tong Xuan and Tran An Phong (1998) History and future of farming systems in the Mekong Delta, in Vo Tong Xuan and Shigeo Matsui (eds), Development of Farming Systems in the Mekong Delta of Vietnam. Ho Chi Minh City: Ho Chi Minh City Publishing House, pp. 16-80.

Pelling, M (1999) The political ecology of flood hazard in urban Guyana, Geoforum, 30, 249-61.

Pham Cao Duong (1985) Vietnamese Peasants Under French Domination 1861-1945, Lanham, MD: University Press of America and Center for South and Southeast Asia Studies, University of California.

Rambo, A T (1973) A Comparison of Peasant Social Systems of Northern and Southern Viet-Nam: A 
Study of Ecological Adaptation, Social Succession, and Cultural Evolution, Carbondale, IL: Center for Vietnamese Studies, Southern Illinois University.

Robequain, C (1944) The Economic Development of French Indochina, Oxford: Oxford University Press.

Sansom, R (1970) The Economics of Insurgency in the Mekong Delta of Vietnam, Cambridge, MA: MIT Press.

Scott, J (1976) The Moral Economy of the Peasant: Rebellion and Subsistence in Southeast Asia, New Haven, CT: Yale University Press.

Swyngedouw, E (1997) Neither global nor local - 'glocalization' and the politics of scale, in K Cox (ed), Spaces of Globalization, Reasserting the Power of the Local, New York: Guilford, pp. 137-66.

Sub-Institute for Water Resources Planning, Ministry of Agriculture and Rural Development (SIWRP) (1997) Short-Term Flood Control Planning in the Mekong Delta (Executive Summary). Ho Chi Minh City: MARD.

Vietnam National Mekong Committee (VNMC) and UNDP (1999) Case Study on Water Management for the Mekong Delta in Viet Nam, Hanoi: UNDP.

World Bank (1999a) Project Appraisal Document on a Proposed Credit of SDR 72.8 Million to the Socialist Republic of Vietnam for the Mekong Delta Water Resources Project. Washington DC: World Bank; 15 Mar 1999a.

(1999b) Vietnam: Attacking Poverty - Vietnam Development Report 2000. Hanoi: World Bank. 


\title{
12 Rethinking watershed science Lessons from Thailand
}

\author{
Tim Forsyth
}

One defining characteristic of the work of Harold Brookfield on environmental problems in developing countries was a disdain for unsophisticated generalizations and a preference for detailed, local empiricism. The objective was not to emphasize description at the expense of theory, but to develop a more contextual and deeper understanding of human relationships and environmental change. This approach influenced two widespread themes of research: the analysis of local people's strategies and innovations for adapting to environmental change, and a focus on the political factors that shape environmental science. Together, these debates have highlighted the importance of both treating common generalizations about environmental change critically and involving diverse social groups and sources of information in understanding environmental change.

This chapter concerns debates about the nature and causes of environmental degradation in upland Thailand, in land officially classified as watersheds or seen to provide water supplies for lowlands. But at a deeper level it illustrates the two themes influenced by Brookfield: local practices adopted by farmers that govern impacts of agricultural intensification on environmental resources, alongside social and political influences on the emergence of environmental generalizations, or popular scientific statements of cause and effect. In Thailand, many government policies state, and public opinion believes, that upland agriculture is primarily responsible for soil erosion and lowland water shortages, and consequently that controlling upland agriculture (including widespread reforestation) will reduce these problems. This chapter presents evidence that challenges these unsophisticated generalizations, and it thus suggests more effective and socially just means of watershed management.

The approach adopted here parallels the regional political ecology approach of Brookfield and Blaikie. In its most general sense, political ecology is a politicized attention to interactions between ecology and society. Blaikie and Brookfield wrote:

The phrase 'political ecology' combines the concerns of ecology and a broadly defined political economy. Together this encompasses the constantly shifting dialectic between society and land-based resources, and also within classes and groups within society itself. 
This chapter illustrates this approach by showing the different conflicts concerning resource use in the uplands. But in addition, Blaikie and Brookfield pioneered attention to the use of environmental science itself as a political force, and consequently the need to question not just political stances about environment, but also the scientific basis upon which they are made:

It therefore becomes necessary to examine critically the political, social and economic content of seemingly physical and 'apolitical' measures such as the Universal Soil Loss Equation, the ' $T$ ' factor and erodibility.

(1987: xix)

This statement is further validated here by showing the contested nature of many of the scientific generalizations used to legitimize different watershed policies. The result of this approach is not to claim that upland agriculture in Thailand has no environmental impact, but rather to show that unsophisticated generalizations may not address the underlying complexity of environmental change and may also result in diminished livelihood prospects for upland farmers. Critically analyzing such statements, and diversifying the information sources to test them, enables a more accurate and socially just means of addressing environmental change.

\section{Watershed degradation and environmental generalizations}

Watershed degradation commonly refers to the degradation of soil, forest, and water retention capacities of upland areas resulting in the loss of water supply to lowlands. Yet watershed degradation also affects different people in different ways. Degradation of watersheds may take place via agricultural practices in watershed areas, resulting in the additional problems of managing agricultural problems such as declining soil fertility or the need to ensure livelihoods for farmers living in affected zones. Much controversy has been caused when approaches to watershed management have implied a choice between the priorities of uplanders and lowlanders, or when the activities of upland agriculture have been blamed for causing alleged damage to watershed properties (e.g. Lal and Russell 1981).

Perhaps the most commonly discussed generalization concerning watershed degradation has been summarized as the so-called 'theory of Himalayan environmental degradation', supposedly characteristic of contemporary changes in Nepal (see Ives and Messerli 1989). This convenient summary of the nature and causes of environmental degradation became popular in environmental debates during the 1970s and continues to influence policy debates. The theory simply proposed a pattern in which increasing population in highland areas resulted in heightened land cultivation and deforestation; which in turn lead to increased soil erosion, declining soil fertility, and lowland sedimentation; which eventually caused water shortages and lowland flooding, plus a self-enhancement of the degradation cycle because of increasing land shortage in the highlands. Over a quarter of a century ago, Eric Eckholm, summarized this pattern in graphic terms: 
Population growth in the context of a traditional agrarian technology is forcing farmers onto even steeper slopes, slopes unfit for sustained farming even with the astonishingly elaborate terracing practiced there. Meanwhile, villagers must roam further and further from their houses to gather fodder and firewood, thus surrounding villages with a widening circle of denuded hillsides.

(Eckholm 1976: 77)

Such statements have generally underpinned much subsequent debate about watersheds and have led to a variety of proposed land use policies. For example, reforestation (or afforestation) is commonly seen to be a cure-all for various watershed degradation problems; and controlling deforestation is seen to be a key factor to control degradation. Indeed, China in 1998 introduced a ban on various forms of deforestation as a response to serious flooding. Thailand in 1989 also enacted a logging ban, partly because of severe deforestation and concern at catastrophic floods in the south of the country in 1988. Statements in the proceedings of the 1992 Earth Summit also reiterated these beliefs about the nature and causes of watershed degradation.

Yet, and perhaps unsurprisingly, such statements about watershed degradation have been criticized in various ways for being simplistic. First, and perhaps most memorably, the book Uncertainty on a Himalayan Scale (Thompson et al. 1986), pointed out that in the Himalayas, a survey of deforestation estimates from between 1965 and 1981 revealed that estimated rates varied by a factor of 67, even after excluding some apparent typing errors. Consequently, there needs to be more attention to why certain estimates of degradation gain more authority within specific political contexts whereas other estimates do not.

Second, much research on the impacts of deforestation and reforestation has also questioned the accuracy of many assumptions about watershed degradation. Hofer (1993), for example, found no statistically significant relationships between river discharge, precipitation and flooding for some of the major watersheds between Nepal and the Gangetic plain. At a smaller scale, Smadja (1992) found no direct relationship between either deforestation or precipitation and erosion on one Nepalese slope. Moreover, Thapa and Weber (1995) apparently contradicted Eckholm's prediction by finding evidence in Nepal that hill farmers avoid steep slopes and consequently have not accelerated deforestation in recent years. Similar geomorphological studies of human activities have questioned the importance of erosion in causing degradation (e.g. Nortcliffe and Dias 1988) or the impacts of deforestation on erosion and water shortages (Hamilton 1988; Hamilton and Pearce 1988; Froehlich and Starkel 1993). Summarizing such assumptions, Calder (1999) has proposed that five so-called 'mother statements' about watershed degradation should be considered misleading 'myths' that need to be reconsidered. Table 12.1 summarizes Calder's findings. These findings also imply that the common policy recommendation of solving watershed degradation through reforestation or afforestation (on the grounds that deforestation caused these problems) may also be flawed.

But, third, local perceptions and management practices may also influence 
Table 12.1 'Mother statements' about watershed degradation and suggested amendments

\begin{tabular}{|c|c|}
\hline 'Mother statement' & Implications from research \\
\hline Forests increase rainfall & $\begin{array}{l}\text { Forests undoubtedly contribute to the production and location } \\
\text { of rainfall, but this contribution is relatively small, and tends to } \\
\text { be overrated. }\end{array}$ \\
\hline Forests increase runoff & $\begin{array}{l}\text { Supplies of water from forests are - in general - less than from } \\
\text { shorter vegetation because of the role of evapotranspiration in } \\
\text { accounting for water use. }\end{array}$ \\
\hline $\begin{array}{l}\text { Forests regulate water } \\
\text { flows, especially during } \\
\text { dry seasons }\end{array}$ & $\begin{array}{l}\text { Results vary on a site-by-site basis. Sometimes, severe shortages } \\
\text { can be experienced in dry seasons. But it cannot be assumed } \\
\text { that afforestation can increase dry-season water supplies } \\
\text { (see row above). }\end{array}$ \\
\hline Forests reduce erosion & $\begin{array}{l}\text { Results vary on a site-by-site basis. The nature of forest type is } \\
\text { important. Research suggests that plantations of teak (Tectona } \\
\text { grandis) may cause severe erosion. Erosion needs to be } \\
\text { distinguished between sheet erosion and gully erosion, with } \\
\text { gullies more likely under trees. }\end{array}$ \\
\hline Forests reduce floods & $\begin{array}{l}\text { Despite much anecdotal associations of floods and } \\
\text { deforestation, there is little scientific evidence of this causal } \\
\text { relationship. }\end{array}$ \\
\hline $\begin{array}{l}\text { Forests 'sterilize' } \\
\text { water supplies }\end{array}$ & $\begin{array}{l}\text { Research supports the statement that water quality is likely to be } \\
\text { better from forested catchments, barring locations in highly } \\
\text { polluted climates. }\end{array}$ \\
\hline $\begin{array}{l}\text { Agroforestry systems } \\
\text { increase productivity }\end{array}$ & $\begin{array}{l}\text { If productivity is defined in terms of logging and timber, then } \\
\text { there is little evidence to suggest that agroforestry yields higher } \\
\text { productivity than other forms of forestry. However, carefully } \\
\text { managed agroforestry may allow a minimum production of } \\
\text { timber with the production of food and non-timber products } \\
\text { for local settlers. }\end{array}$ \\
\hline
\end{tabular}

Source: after Calder 1999: 22-37; see also Hamilton 1988; Hamilton and Pearce 1988.

which changes are considered problematic. Not all land users experience similar forms of environmental change as uniformly problematic, and many users reduce their impacts on the environment. For example, several studies of land use have revealed that many farmers could adapt to problems of erosion or landslides by developing indigenous technology to reduce the impact of processes on agricultural production (e.g. Filpi et al. 1983; Gurung 1989). Indeed, some farmers even triggered landslides themselves as a mechanism to renew soil fertility and facilitate terrace construction (Kienholz et al. 1984; Metz 1991: 810). Brookfield commented on the tendency of universal declarations of environmental crisis to overlook the ability of farmers to reduce risks:

The management of many areas, to reduce risk, control erosion, or bring into cultivation land that would otherwise be unusable, requires physical works to modify the surface. Often erroneously described as an element of 'intensifi- 
cation,' this is more properly 'innovation,' which may or may not later be intensified by the application of additional labor.

Yet, related to this, it is also clear that the capability to adopt such innovations is not uniform, and depends partly upon the existence of supporting social and economic factors such as land tenure, proximity to markets, or access to certain state services such as agricultural extension advice and credit. Although many farmers do adopt strategies to protect soil and water against degradation, such practices are more likely where people have security of tenure and incentives to invest in such activities. The construction of terraced land, in particular, is an example of soil conservation and innovation that requires high labour inputs, usually only achievable where people believe they can benefit from this in years to come.

There is therefore much evidence to suggest that policy approaches to watershed management are based on unsophisticated generalizations; particularly there is a belief that deforestation is the main cause of water shortages, and consequently that reforestation is a solution. These statements have been widely questioned by a variety of physical scientists:

The worldwide evidence that high hills and mountains usually have more rainfall and more natural forests than do the adjacent lowlands has historically led to confusion of cause and effect. Although the physical explanations have been known for more than 50 years, the idea that forests cause or attract rainfall has persisted. The myth was created more than a century ago by foresters in defence of their trees... The myth was written into the textbooks and became an article of faith for early generations of foresters.

(Pereira 1989: 1)

Yet, as indicated by anthropological research, the dilemma of unsophisticated generalizations is not restricted to biophysical debates about causality, but rather to questions of human experience and involvement in practical solutions. Watershed degradation is experienced both by upland farmers and lowland dwellers, and adopting simplistic solutions such as widespread reforestation may neither address the underlying degradation nor contribute to upland livelihoods if applied in insensitive ways. Instead, watershed degradation needs to be addressed by considering the diverse perspectives and needs of different users in order to achieve a more achievable and just solution to environmental problems.

\section{Northern Thailand: background}

The mountains of northern Thailand provide an opportunity to illustrate debates about watershed degradation. Northern Thailand is neither as high nor tectonically active as the Nepal Himalaya, and it is hydrologically different to Nepal through having no snow and ice to store water to be released during the dry season. However, the region has many of the contextual aspects for the theory of 
Himalayan environmental degradation, and has experienced important political conflicts between uplanders and lowlanders concerning reforestation and watershed management. Repeating the concerns of Eckholm (1976), Ives argued that:

Serious land shortage [in northern Thailand] has reduced the traditional periods of forest fallow so that the old systems are on the verge of collapse. Soil erosion, decreasing soil fertility, progressive deforestation and spread of Imperata grasslands are all contributing to a critical situation in the mountains, which also has increasingly heavy impacts on the settled agricultural systems of the lowlands.

(1980: 10)

Such views also affect official policy statements from the Royal Forestry Department, established in 1896. The department wrote:

Everyone knows that forest is the source of water for all people who live on Thai soil. We do not have any other source of water in Thailand ... [the forest] provides for underground water storage, making the ground moist as a benefit for all people. ... The result of cutting forest is the destruction of the water source of the Thai people.

(Royal Forest Department/Suan Pa Sirikit n.d; in Walker, n.d.: 1)

Environmental policy in northern Thailand, however, has been highly influenced by the differences in ethnic composition of uplanders and lowlanders, and the political history of security in the region. Classically, the first Thai (or T'ai) kingdoms (muang) were located in intermontane basins since the late thirteenth century, where settlers grew irrigated rice. The upland regions were for centuries typically inhabited by ethnic minorities, such as the Karen or Lawa, who classically used 'rotational' forms of shifting cultivation based upon a regular system of land fallow around semi-permanent villages. Since the 1850s, however, and particularly since the 1950s, these groups have been supplemented by different ethnic minorities, such as the Hmong and Mien, who classically use more 'pioneer' forms of cultivation, based on cultivating land intensively for 10-20 years before moving to a new location (see Grandstaff 1980). Although both types of cultivation may be claimed to be ecologically sustainable if sufficient space and recovery time are available, land shortage in Thailand has meant that most 'pioneer' cultivators are no longer able to relocate villages, and hence they are now experiencing long-term problems of declining soil fertility. Furthermore, increasing pressure for land from lowland farmers now turning to the highlands and from new ventures such as tourist developments and second homes - also mean that claims on the uplands are becoming more complex.

Such contested land uses illustrate various themes within regional political ecology. But in addition, the environmental management of the northern Thai uplands has been associated with historic concerns from the Thai state that upland minorities represented security risks, by potentially being source areas for insurgency 
during the Vietnam War era or through the illicit cultivation of opium. Such concerns have led to a strategy of resettlement, reforestation and agricultural extension work since the 1960s. Furthermore, a rising middle class in Thailand has blamed upland agriculture for loss of forest land and has linked agriculture to lowland water shortages and lost rainfall. In recent years, these approaches to upland agriculture in Thailand have led to political protests. In May 1999 some 5,000 farmers, primarily from upland areas, congregated outside the Chiang Mai provincial hall to demonstrate against official reforestation policies and to request greater ability to achieve Thai citizenship for ethnic minorities. The Thai government has traditionally resisted giving citizenship on a widespread basis for fear that it may legitimize further immigration to the highlands. But lack of citizenship, and the threat that agricultural land may be reforested, are potential reasons not to adopt environmental innovations to protect land against degradation.

The rest of this chapter analyzes underlying assumptions about the nature and causes of watershed degradation in Thailand, and seeks to demonstrate the value of local empiricism in challenging these. In the spirit of Brookfield, this analysis shows the role of local land use strategies in enhancing or reducing environmental degradation, and of a wider politics in shaping what is seen to be environmental science.

\section{Water shortages}

Water shortages in the lowlands of Thailand are one of the most important social and environmental problems experienced each year. Shortages during the dry season of October to April are commonly blamed on upland deforestation, as are flash floods in Bangkok during the rainy season. As has already been discussed, deforestation is often considered to be the chief underlying cause for decreased rainfall and damaged water retention capacities of watersheds. A 1999 magazine for tourists, for example, contained an article sensationally entitled 'There's no doubt - it's a drought!', which concluded: 'the bottom line is forests decimated by excessive tree felling and land denuded by slash-and-burn agriculture severely reduce cloud formations - and thus rainfall, the main cause of Thailand's drought' (Thinnsawat and Hardy 1999: 23).

Environmental change is, unsurprisingly, much more complex. Alford (1992) conducted a study on water yield in northern Thailand, looking specifically at the net runoff from river basins, and the apparent relationship with swidden agriculture. The study is the only long-term historical account of water shortages in northern Thailand, yet its results are generally not adopted by policy-makers or campaigners.

The study collected data for the headwaters of the Chao Phraya river in northern Thailand (Figure 12.1) - the upper watersheds of the Wang, Ping, Nan and Yom rivers. Data were collected for precipitation, streamflow and suspended sediment. Rainfall data from 1976 to 1987 were used from 37 out of 52 stations, and streamflow data from 23 subcatchments throughout the north. Long-term trends were then estimated from these data, although some missing records meant that such trends could only be approximate. 


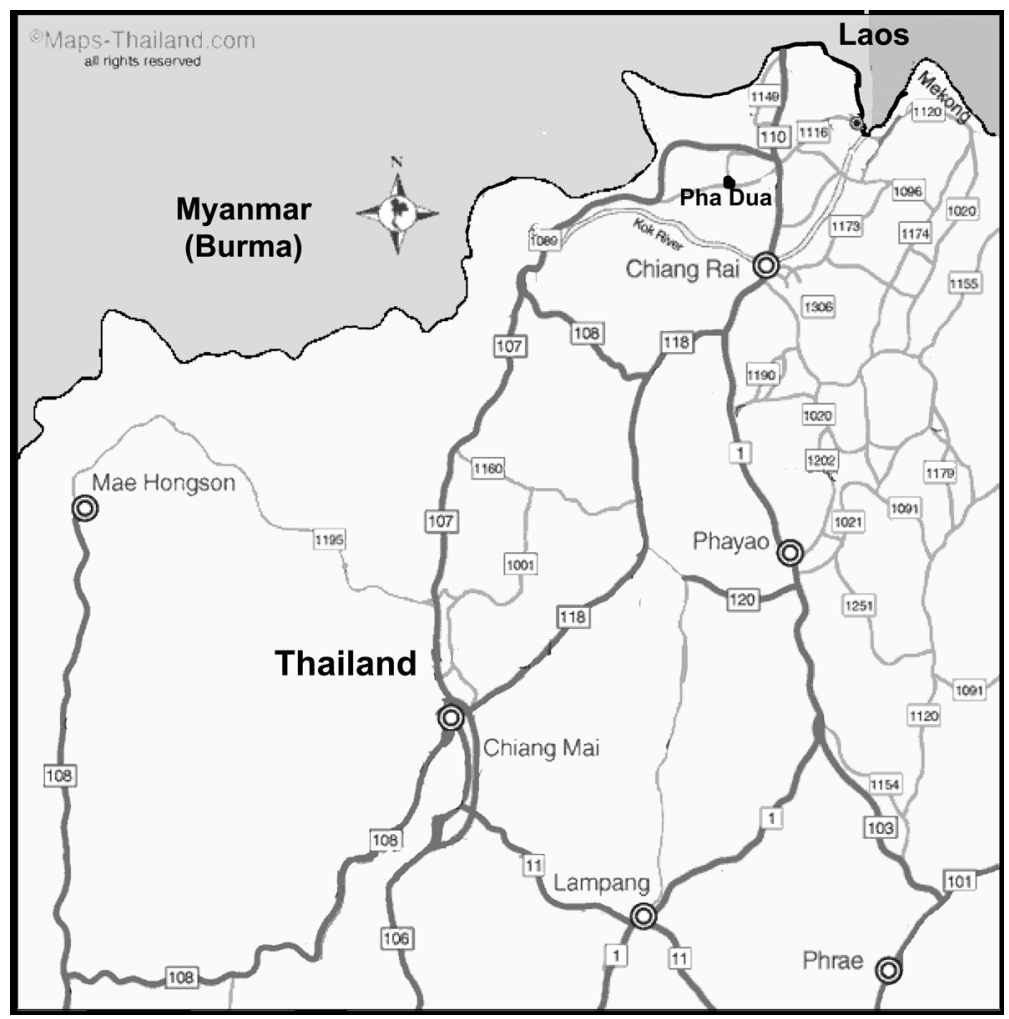

Figure 12.1 Northern Thailand.

The research produced two sets of information concerning streamflow and sediment discharge. The 'runoff efficiency' of subbasins was calculated as the ratio between water input as precipitation and output as streamflow. Annual hydrographs were also prepared for selected basins to enable a comparison of wet and dry seasons. Annual values of sediment transport per square kilometre were calculated for subbasins, and this value was then compared with streamflow, expressed in cubic metres per second, to produce an initial estimate of the importance of river hydraulics in determining the amount of suspended sediment flowing annually through each river system. This analysis also provided an initial indication of any changes in sediment transport with time and allowed preliminary conclusions concerning the relative importance of climate and land use practices in producing these changes.

The results indicated two important findings for the origins of water shortages in northern Thailand. First, runoff efficiency from the four basins was comparatively low, at just 20 per cent. The total volume of water produced by the Ping, Wang, Yom and Nan rivers in the north (a total surface area of 45,474 square kilometres) is 12,390 cubic metres or approximately 290 millimetres, a value twice the specific 
runoff depth given by other consultants for the 'North' region as a whole. This volume represents about 40 per cent of the total flow of the Chao Phraya river at its mouth near Bangkok and originates from approximately 25 per cent of the total surface area of the Chao Phraya basin. The study estimated that about 60,000 million cubic metres of water are added to the system each year as precipitation. This gives a regional value for runoff efficiency of about 20 per cent.

The second important finding was that there was no observed change in precipitation or suspended sediment as the result of increasing agricultural production in the region. Suspended sediment transport through the system is comparable with the lowest values measured in river systems of the world (Ferguson 1982). Values range from a low of 44 tonnes per square kilometre in the Ping river to a high of 256 tonnes per square kilometre in the Nan river. For comparison, the Hunza river in Pakistan has a sediment load of 13,200 tonnes per square kilometre, while the Tamur river in eastern Nepal carries 5,500 tonnes per square kilometre. Monthly variations of streamflow do not follow those of precipitation in a consistent manner. While precipitation increases in May, significant increases in streamflow do not occur until August. Streamflow declines directly with the cessation of rainfall at the end of the 'wet' season, an indication of very limited storage (soil moisture and groundwater) in these mountain basins. Flow of water from the northern mountain basins of the Chao Phraya river varies by as much as two orders of magnitude between the 'dry' and 'wet' seasons. While this is comparable with other mountain regions of Asia, it is at least an order of magnitude greater than the mountains of North America and Europe, where most water resources development technologies have evolved.

The study also revealed that year-to-year variations in both precipitation and streamflow were not as extreme as seasonal differences. In general, precipitation varied by a factor of approximately two from one year to the next, while total annual streamflow might vary by a factor of three or four. The data were not sufficient to permit a determination of the cause(s) of the relative difference in the variability of precipitation and streamflow. These may be due to differences in factors such as storage or evaporation, or fluctuations in some resource use such as irrigation withdrawal. However, the relationship between sediment transport is much more constant on a year-to-year basis than are streamflow and precipitation. The close correspondence between streamflow and sediment transport implies a sediment source within the stream channel, rather than erosion from slopes contributing sediment to this channel.

The implications of these results are that the mountains of northern Thailand are unusually dry in terms of runoff efficiency - or streamflow as a proportion of precipitation. The available evidence suggests that upland agriculture is not significant in producing this effect, but that this dryness is probably long-standing and possibly naturally occurring. A further possible cause of apparent dryness in the lowlands is the extensive irrigation, which prevents precipitation reaching streams. Indeed, a further study, conducted by Walker (n.d.) during the 1990s, indicated that water supply to the lowlands had actually decreased while forest cover in the highlands had increased. This study, in an area inhabited by Karen farmers in 
the Mae Chaem catchment of Chiang Mai province, suggested that the greatest impact on water supply had come from the increase in lowland cultivation of fruit trees (particularly longan and lychee) during the 1990s.

Such studies certainly do not reduce the significance of water shortages as an environmental problem for many lowland and upland agriculturalists in Thailand. Nor do they suggest that upland agriculture had no impact on the environment. Indeed, forest quality is likely to be decreased by agriculture, and some impacts on water supply will result from changes in land use and cover. But the studies do suggest that the notion that upland agriculture and forest cover alone are responsible for water shortages is flawed. At the very least, they indicate that changes in sediment and water releases cannot be detected at the scale of the existing monitoring network.

\section{Soil erosion}

Upland agriculture is commonly blamed for causing soil erosion, leading to reduced upland soil fertility and lowland sedimentation. Reduced soil fertility in the uplands may increase pressures for more deforestation. Lowland sedimentation may damage lowland irrigation and freshwater fisheries. An alleged cause of soil erosion is population pressure leading to the cultivation of steeper slopes, as expressed under the theory of Himalayan environmental degradation. One study sought to test this assertion by measuring how far one upland village had cultivated steeper slopes over a period of some 45 years (Forsyth 1994, 1996). The study was based in Chiang Rai province, where a community of historic shifting cultivators of the Mien minority had settled since 1947. Historically, the Mien relocated villages every 10-20 years, once the land around the village became exhausted. However, many villages in Thailand have become sedentary, and the Mien have had to adapt to declining soil fertility (Figure 12.2 and Figure 12.3). Originally consisting of 10 households (about 110 people) in 1947, the village in 1995 contained 118 households (900 people).

The study used three main techniques. Aerial photographs and geographical information system (GIS) were employed to map historic changes in land cover and to develop a map of predicted soil erosion. Caesium-137 measurements of soil erosion were then used to test the map and measure historic soil erosion between 1963 and 1991. Interviews, participant observation and participatory discussions with farmers were then held to collect farmers' opinions about land use and soil degradation.

Historic photographs for the years 1954, 1969, 1977, 1983 and 1987 were used to create maps of historic land use and a topographic base map at a scale of 1:15,000 for an area of approximately 12 square kilometres. The photographs varied in scale between $1: 15,000$ and 1:50,000 and consequently only those features visible at 1:50,000 were used for the land use maps. All photographs dated from the cold-dry season, and gave indication of closed forest, bamboo regrowth, grassland and freshly cultivated soil. ArcInfo GIS was then used to create: (i) a map of slope steepness from the topographic map; (ii) a map of historic frequency of 


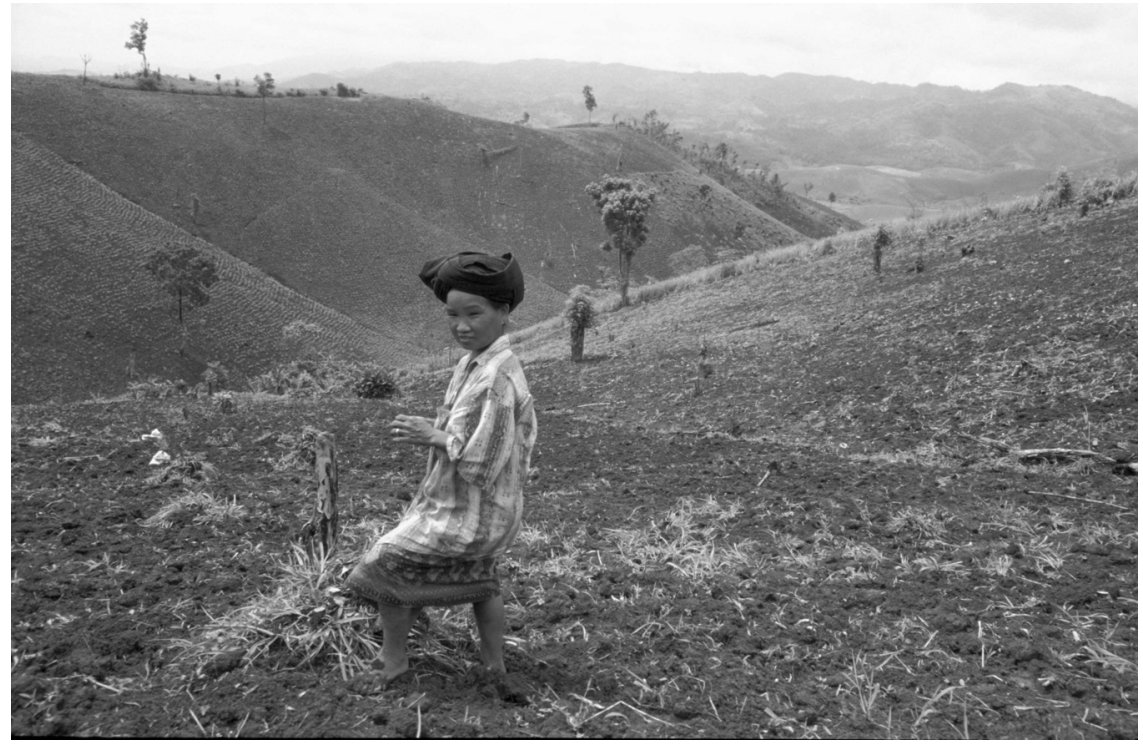

Figure 12.2 Yao woman farmer on steep, cultivated slopes, northern Thailand.

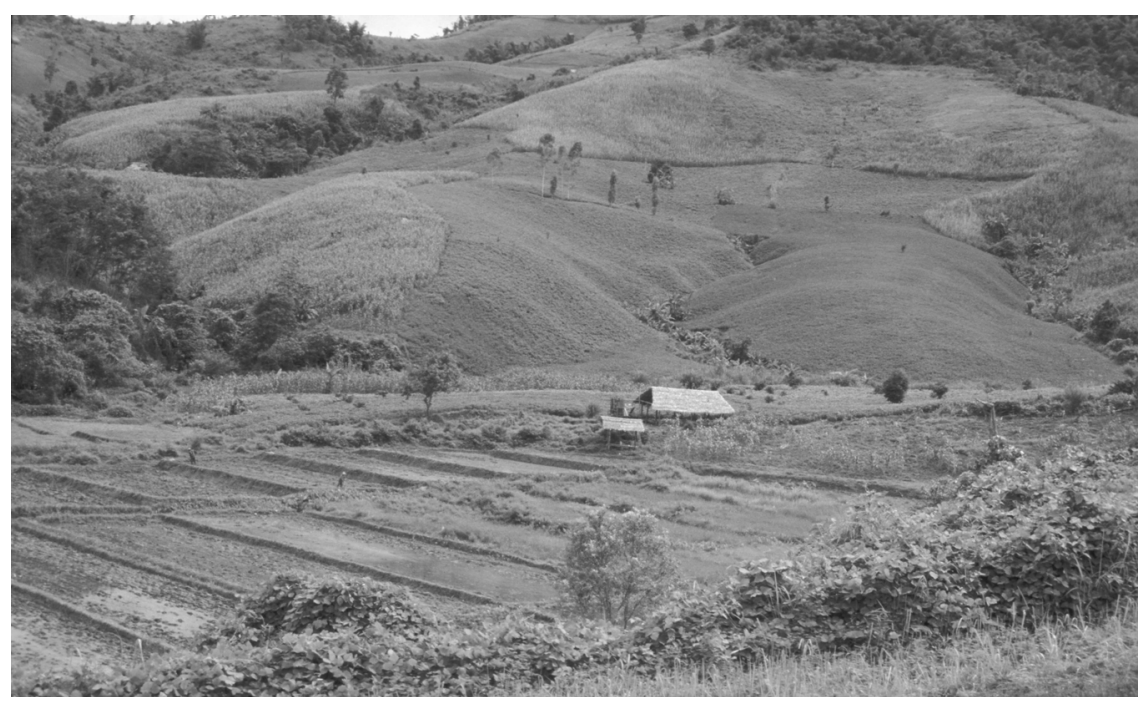

Figure 12.3 Pha Dua village agriculture, northern Thailand.

cultivation by integrating the land use maps; and (iii) a map of predicted erosion by integrating the historic cultivation map with slope steepness. The caesium-137 method was used to verify this last map, and statistically significant differences were found between soil erosion in the 'least' and 'most' eroded categories. ${ }^{1}$ Villagers were then questioned for other information. 
The study provided three key findings. First, and most important, the comparison of historic cultivation and slope steepness indicated that farmers had actually not cultivated steeper slopes as a result of population growth, but had cultivated more frequently on flatter slopes. Figure 12.4 shows the distribution of categories of predicted erosion. The category of most erosion is significantly smaller than other categories, indicating that relatively little cultivation has taken place on the steepest slopes. Meanwhile, villagers complained that they were compelled to cultivate crops increasingly frequently on less steep slopes. The caesium-137 measurements revealed that historic soil erosion rates for 1963-99 were between 24 tonnes per hectare per year (standard error 15 per cent) for the 'least eroded' category, and 64 tonnes per hectare per year for the 'most eroded' area (standard error 11 per cent). These figures are consistent with rates on granite measured elsewhere in Thailand, although the higher rate refers to only some 5 per cent of the research area.

Second key finding was that much landscape dissection in the area may be naturally occurring and pre-date agriculture. GIS data on slope steepness indicated a marked absence of slopes between a steepness of 10 and 20 degrees (see Figure 12.5), and field surveys revealed a large number of deep gullies. Such gullies and slope profile are characteristic of a so-called 'all-slopes-topography' found on tropical granite land globally (Twidale 1982: 177), or of the deep, naturally occurring gullies in Nepal referred to as pahiros (Smadja 1992: 7). Villagers explained that the gullies existed before the village was established, and that they had occurred under forest land as well as on fields. It is therefore probable that much movement of sediment from the uplands to the lowlands originated from these gullies rather than from the agricultural areas. Villagers often left these gullies and their surrounding slopes uncultivated, and therefore the vegetation on these slopes would reduce the

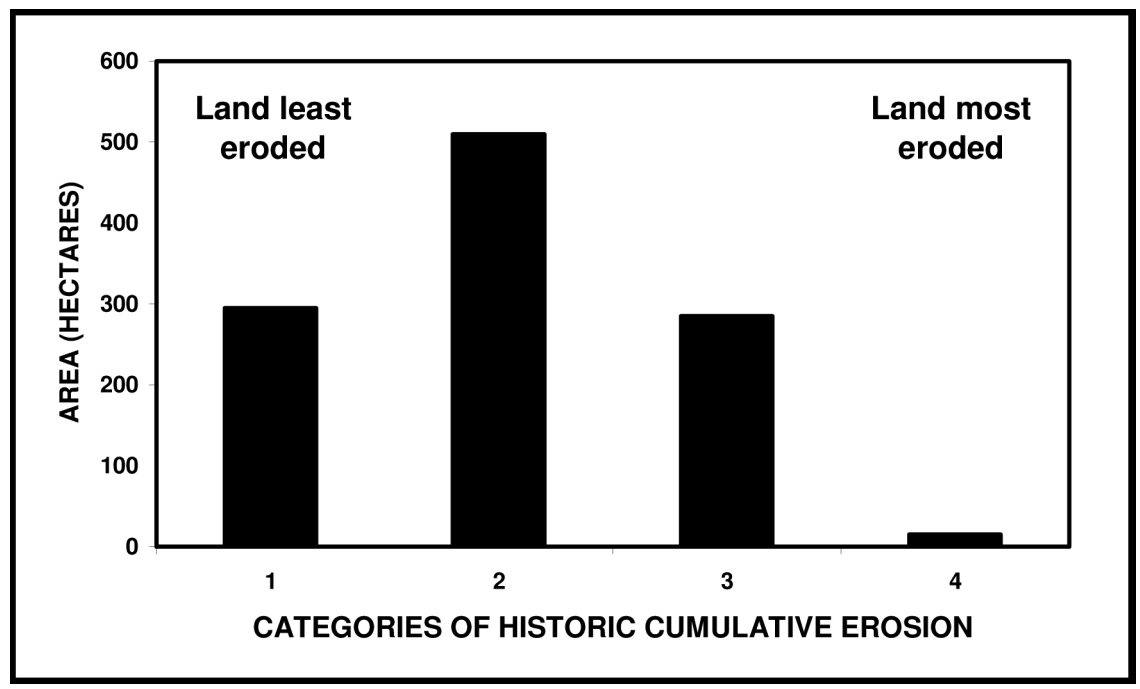

Figure 12.4 Categories of predicted soil erosion (indicating historic cultivation per slope steepness). 


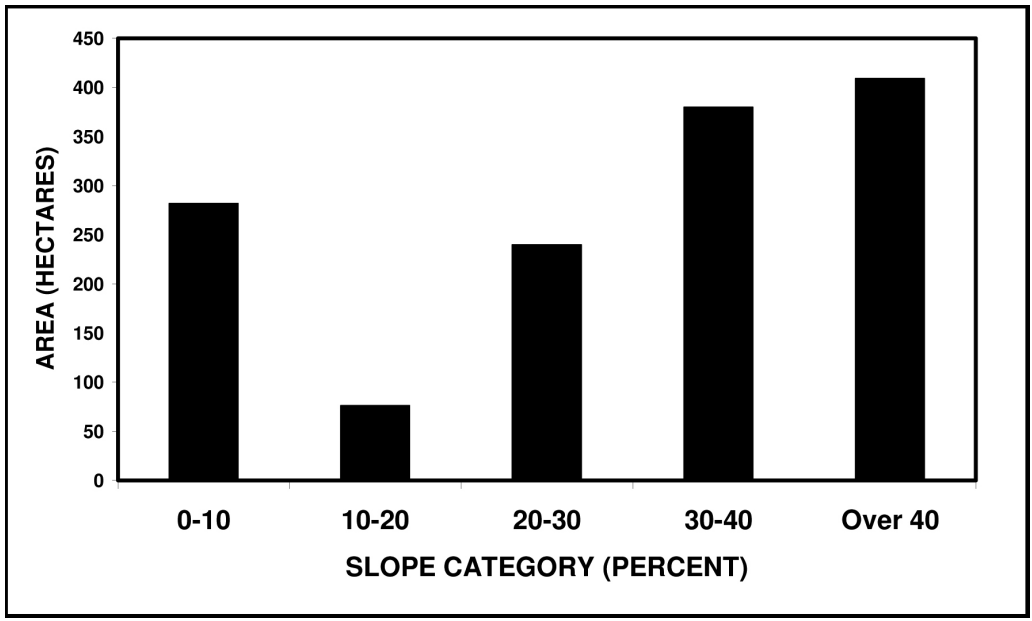

Figure 12.5 Categories of slope steepness.

input of soil into gullies from surrounding cultivated fields. If villagers had removed this vegetation, sediment would probably enter the gullies and wash down the slope.

The final key finding was based on the history of land cover change in the village provided by the aerial photographs (see Table 12.2). Closed forest declined rapidly from 441 to 69 hectares between 1954 and 1969, probably because of the influx of shifting cultivators, yet by 1991 total closed forest had risen to 348 hectares (including 131 hectares of plantation). Villagers explained that after about 25 years of settlement inhabitants decided to make the village permanent, first establishing a village woodlot and then a new land-tenure system as a way to manage land ownership. The new tenure system probably increased the frequency of cultivation on some plots as a means of indicating land ownership. The study therefore showed that - contrary to some expectations - upland farmers had actually allowed forest land to recover and had avoided cultivating the steepest slopes.

\section{Thai highland studies}

These empirical studies in northern Thailand illustrate the value of particular studies as an alternative to unsophisticated generalizations in the explanation and management of environmental problems in developing countries. The focus on water shortages and erosion indicates that popular and/or state-based explanations of environmental degradation overlook the local environmental strategies adopted by upland farmers and the ways in which social and political factors influence the adoption of environmental generalizations. Both studies indicate the need for the political ecology approach proposed by Blaikie and Brookfield (1987).

It is clear that the common belief that upland agriculture causes water shortages and soil erosion overlooks many biophysical processes that pre-date agriculture. 
Table 12.2 Areas of historic cold-dry season land uses in the Chiang Rai mountain village $(\text { hectares) })^{1}$

\begin{tabular}{lrrrr}
\hline & \multicolumn{1}{l}{ Year } & & \\
\cline { 2 - 5 } & $1954^{2}$ & 1969 & 1977 & 1991 \\
\hline Closed forest $^{3}$ & 440.5 & 78.6 & 212.6 & 216.6 \\
Bamboo regrowth $_{\text {Grass }}$ & 652.9 & 19.5 & 705.9 & 332.7 \\
Bare soil $_{\text {Rice terraces }}^{4}$ & 120.6 & $1,130.9$ & 146.5 & 587.6 \\
RFD land $^{5}$ & 82.0 & 53.8 & 73.1 & 10.9 \\
Settlement & - & - & 25.5 & 8.9 \\
\hline
\end{tabular}

Sources:

1954, 1969: 1:50,000 aerial photographs.

1977: 1:15,000 aerial photographs.

1991: field survey (January).

All photographs dated January except 1969 (February) and 1983 (November).

Notes

1 Historic aerial photographs from 1983 and 1987 were also used for mapping but covered respectively only 75 per cent and 76 per cent of the study area defined by the topographic map, and so were excluded from the table.

2 The village was established in 1947.

3 Closed forest, bamboo regrowth, grass and bare soil were the only categories used to construct the index of historic frequency of cultivation. Closed forest was taken to indicate an absence of cultivation for 10 or more years; bamboo for 2 to 10 years; grass for 1 to 2 years; and bare soil indicating current cultivation. It is acknowledged that these figures do not indicate internal forest quality.

4 Rice terraces were said by informants to be increasing, and so the low 1991 figure is probably a mapping error resulting from the misinterpretation of grass during field survey.

5 Royal Forestry Department reforested land, established early 1970s (in addition to the village woodlot).

The study of water shortages revealed that the watersheds of northern Thailand have some of the lowest water delivery ratios recorded in the world, and that changes in upland agriculture had no discernible impact when using basin-wide statistics (Alford 1992). Although this study was undertaken after the majority of land use changes in northern Thailand, its conclusion has been supported by studies in watersheds elsewhere (Calder 1999). The study of soil erosion indicated that much lowland sedimentation originated from naturally occurring gullies, though this does not mean that upland agriculture has no impact on erosion or water retention. However, water shortages and erosion are - at least in part affected by long-term biophysical properties that pre-date agriculture. Hence, policies aiming to address water shortages and sedimentation purely by targeting upland agriculture may not succeed in stopping these problems. Moreover, many upland communities adopt methods to reduce impacts on resources - a trend observed by Brookfield in many locations of presumed environmental crisis and by other authors (e.g. Batterbury and Forsyth 1999). In Chiang Rai, Mien farmers avoid cultivating the steepest slopes because they acknowledge that it accelerates erosion. It would therefore be wrong to suggest that farmers do not protect resources or are unaware of the risks of agriculture. 
The role of values and perception is crucial in defining degradation. Lowland communities experience problems of water shortages and sedimentation. But currently these are generally explained in direct causal terms relating to upland agriculture, rather than in phenomenological terms such as the increasing experience of water shortages or sedimentation by a growing population at the base of the mountains. Furthermore, most discussion of water shortages in Thailand focuses on presumed water supply from the uplands rather than the role of water demand in the lowlands, which is growing substantially, largely because of irrigated rice fields and fruit trees, urbanization and the growth of industrial estates. Thailand is one of the world's largest exporters of irrigated rice, and it is increasingly producing fruit crops, which require regular supplies of water.

Finally, however, the ability of upland communities to adopt land conservation measures depends on secure access to resources. Forest area under the Mien declined until the time they instigated a land-tenure system. Indeed, in northwest Vietnam, some ethnic groups related to the Hmong and Mien have built rice terraces on steep slopes because they were given the right to live there by Ho Chi Minh some 40 years ago. In Thailand, the Hmong and Mien have been characterized as being least interested in soil conservation (e.g. Oughton 1971), yet few villages have secure tenure and to date only about a third of highland minorities in Thailand have citizenship. Many anthropologists have also pointed to political uncertainty concerning the status of ethnic minorities in Thailand, which can only add to the difficulties of investing time and effort into building effective new forms of soil and water conservation.

It seems clear, therefore, that orthodox explanations of watershed degradation - that upland agriculture causes water shortages and erosion, and that plantation forestry is a solution to both - are too unsophisticated and may only add to underlying environmental problems as well as diminish livelihood prospects for upland farmers. It is also clear that these inaccurate explanations have resulted from the framing of environmental problems largely through lowland objectives. Such objectives may include seeking to address water shortages by looking at water supply only, or from the desire to integrate upland watershed policy with other objectives, such as controlling land inhabited by ethnic minorities or restoring lost forests in their own right. Increasing, however, the participation of upland farmers in explaining environmental problems has shown the diversity of environmental change and the complex relationships of upland agriculture to these problems. Upland agriculture of course still has impacts on watershed services and landscapes. But the evidence outlined here suggests it may be possible to address lowland environmental problems and assist upland agriculture at the same time through better local empirical studies, and thus decreasing reliance on unsophisticated generalizations.

\section{Conclusion}

This chapter has summarized debates concerning watershed degradation in Thailand in order to argue that we should avoid unsophisticated generalizations 
about watershed degradation. Instead, we should seek greater complexity in how we explain and manage change based on a greater attention to local environmental practices, experiences and impacts. Greater complexity can come in three important ways. First, we should ask how far common generalizations about environmental change acknowledge complex and long-term biophysical factors. For example, in Thailand, the statement that upland agriculture causes soil erosion and water shortages fails to acknowledge the role of granite weathering on gully formation, or of deep soil profiles on water shortages, both of which pre-date agriculture. Related to this, we should consider the holistic causes of environmental problems, for example by considering the increasing demand for water in lowlands as well as potential threats to supply from uplands.

Second, we need to include the perspectives and practices of upland minorities in the research process. Common statements about watershed degradation in Thailand overlook the various innovations practised by local highlands people that may reduce erosion or protect soil and water resources. Connected to this, there needs to be greater attention to the necessary political and socio-economic factors that allow such innovations to take place. Few farmers will build rice terraces if they do not believe they will be allowed to stay on this land. Allowing farmers security to use land will provide incentives to adopt practices that will both protect resources and enhance livelihoods.

Third, we should ask how far existing generalizations about environment reflect or legitimize the objectives of dominant actors. In Thailand, the belief that upland agriculture causes erosion and water shortages provides support for various political strategies, such as relocating upland minorities, restrictions on citizenship or the use of widespread plantation forestry. Such policies, as has been have discussed, do not necessarily address the problems of water shortages and erosion, and may even exacerbate them. They also work against the adoption of land use innovations by upland farmers, and diminish the prospects of building long-term sustainable livelihoods by poor farmers. Consequently, a variety of research on participatory watershed management in general has urged the greater incorporation of local farmers into the formulation and implementation of management strategies (see Heathcote 1998; Farrington et al. 1999).

Avoiding simplistic generalizations in environmental explanation, and instead understanding both the politics of, and the participatory nature of, alternative forms of environmental science, endorse the pioneering work of Harold Brookfield on these themes, and particularly through his development of political ecology. He wrote:

The 'population-environment nexus' is a big and complex place, and what we really know about it in the development country rural context is exceeded by what we do not know. ... No-one has been able to demonstrate a direct method through which such a linkage is achieved.

It is here argued that all environmental science needs to be evaluated in terms of 
how far it reflects wider political objectives, and how far it includes participation from diverse actors. As Brookfield urged, we must appreciate that there is great uncertainty about many generalizations on the causes and impacts of environmental degradation. Critical analysis of these generalizations, and listening more to local people affected by them, will allow environmental explanations to address underlying problems more effectively and assist in building local livelihoods.

\section{Note}

1 The caesium-137 method measures isotopes deposited on soil after the thermonuclear bomb tests of the 1950s. Sites undisturbed since this time are compared with sites that have undergone erosion or deposition. The benefits of the technique are tempered by the need for sophisticated equipment and multiple measurements to reduce measurement errors (Ritchie and McHenry 1990).

\section{References}

Alford, D (1992) Streamflow and sediment transport from mountain watersheds of the Chao Phraya basin, northern Thailand: a reconnaissance study, Mountain Research and Development, 12, 257-68.

Batterbury, S and Forsyth, T (1999) Fighting back: human adaptations in marginal environments, Environment 41(6), 6-11, 25-30.

Blaikie, P and Brookfield, H (eds) (1987) Land Degradation and Society, London: Methuen.

Brookfield, H (1995) Postscript: The 'Population-Environment Nexus' and PLEC, Global Environmental Change, 5, 381-93.

Calder, I (1999) The Blue Revolution: Land Use and Integrated Water Resources Management, London: Earthscan.

Eckholm, E (1976) Losing Ground: Environmental Stress and Food Problems, New York: WW Norton.

Farrington, J, Turton, C and James, A (eds) (1999) Participatory Watershed Development: Challenges for the Twenty-First Century, Oxford: Oxford University Press.

Ferguson, R (1982) Sediment load of the Hunza River, in K Miller (ed.) The International Karakorum Project, Volume 2, Cambridge: Cambridge University Press, pp. 581-98.

Filpi, J, Fuentes, E, Donoso, S and Martinic, S (1983) Environmental perception of mountain ecosystems in central Chile: An exploratory study, Human Ecology, 11, 345-51.

Forsyth, T (1994) The use of cesium-137 measurements of soil erosion and farmers' perceptions to indicate land degradation amongst shifting cultivators in northern Thailand, Mountain Research and Development, 14, 229-44.

- (1996) Science, myth and knowledge: Testing Himalayan environmental degradation in Thailand, Geoforum, 27, 375-92.

Froehlich, W and Starkel, L (1993) The effects of deforestation on slope and channel evolution in the tectonically active Darjeeling Himalaya, Earth Surface Processes and Landforms, $18,285-90$.

Grandstaff, T (1980) Shifting Cultivation in Northern Thailand: Possibilities for Development, UNU Resource Systems Theory and Methodology Series, No.3, Tokyo: United Nations University.

Gurung, Sumitra M (1989) Human perceptions of mountain hazards in the KakaniKathmandu area: experiences from the Middle Mountains of Nepal, Mountain Research and Development, 9, 353-64. 
Hamilton, L (1988) Forestry and watershed management, in J Ives and D Pitt (eds) Deforestation: Social Dynamics in Watershed and Mountain Ecosystems, London: Routledge, pp. 99-131. -and Pearce, A (1988) Soil and water impacts of deforestation, in J Ives and D Pitt (eds) Deforestation: Social Dynamics in Watershed and Mountain Ecosystems, London: Routledge, pp. 75-98.

Heathcote, I (1998) Integrated Watershed Management: Principles and Practice, Chichester: Wiley.

Hofer, T (1993) Himalayan deforestation, changing river discharge, and increasing floods: myth or reality?, Mountain Research and Development, 13, 213-33.

Ives, J (1980) Northern Thailand: the problem, in J Ives, S Sabhasri and P Vorauri (eds) (1980) Conservation and Development in Northern Thailand, proceedings of a programmatic workshop in agroforestry and highland-lowland interactive systems, held at Chiang Mai, 1980, NRTS-3/UNUP-7, Tokyo: United Nations University Press, pp. 9-12.

and Messerli, B (1989) The Himalayan Dilemma: Reconciling Development and Conservation, London: Routledge.

Kienholz, H, Schneider, G, Bichsel, M, Grunder, M and Mool, P (1984), Mapping of mountain hazards and slope stability, Mountain Research and Development, 4, 247-66.

Lal, R and Russell, E (eds) (1981) Tropical Agricultural Hydrology: Watershed Management and Land use, Chichester: Wiley.

Metz, J (1991) A reassessment of the causes and severity of Nepal's environmental crisis, World Development, 19, 805-20.

Nortcliffe, S and Dias, A (1988) The change in soil physical conditions resulting from forest clearance in the humid tropics, Fournal of Biogeography, 15, 61-6.

Oughton, G (1971) Swidden cultivation and forest destruction in northern Thailand, Pacific Community, 9, 77-88.

Pereira, H (1989) Policy and Practice in the Management of Tropical Watersheds, Boulder, CO: Westview Press.

Ritchie, J and McHenry, J (1990) Application of radioactive caesium-137 for measuring soil erosion and sediment accumulation rates and patterns: a review, foumal of Environmental Quality, 19, 215-33.

Smadja, J (1992) Studies of climatic and human impacts and their relationship on a mountain slope above Salme in the Himalayan Middle Mountains, Nepal, Mountain Research and Development, 12, 1-28.

Thapa, Gopal B and Weber, K (1995) Status and management of watersheds in the Upper Pokhara Valley, Nepal, Environmental Management, 19, 497-513.

Thinnsawat, T and Hardy, D (1999) There's no doubt - it's a drought, Good Morning Chiang Mai, 4 (3), March, 12-23.

Thompson, M, Warburton, M and Hatley, T (1986) Uncertainty on a Himalayan Scale: An Institutional Theory of Environmental Perception and a Strategic Framework for the Sustainable Development of the Himalayas, London: Ethnographica, Milton Ash Publications.

Twidale, C (1982) Granite Landforms, Amsterdam: Elsevier.

Walker, A (no date) Forests and Water in Northern Thailand, unpublished paper, Department of Anthropology, Australian National University. 


\section{Givil society and interdependencies

\author{
Towards a regional political ecology \\ of Mekong development
}

Philip Hirsch

The Mekong River has become an icon of regional integration and contested development in mainland Southeast Asia. Geopolitical change in Indochina, Thailand's rapid economic growth and economic transformation during the 1980s and 1990s until the financial crisis of 1997, and the reorientation of the 'socialist market economies' in the wake of the Cold War have led to a repositioning, both globally and in regional terms. The Mekong is thus much more than a river system, and in many ways the naturalising discourse is more incidental than substantive to the integrative development agenda. Yet the nature of developments in the Mekong Basin also requires attention to biophysical interdependencies that are today more salient than ever, as the river's macroecology is altered in the name of regional progress. This tension over what exactly defines the Mekong begs the key questions underlying the main theme of this chapter - how is the Mekong understood as a region by different actors?, and how do these understandings enter the contested discourses of development and ecology?

The chapter aims to provide a framework for understanding 'the Mekong' that engages with both the discourse and the material substance of integration and interdependency, in both developmental and river basin contexts. Definition of region draws, inter alia, on two key themes that remain somewhat separate in Harold Brookfield's writings. The first theme is development as dialectic, an interdependent process of linkage and incorporation that represents a particular type of societal change associated with modernity rather than an end state to be achieved. This can also be seen as a regional expression of interlinkage that is more commonly understood under the rubric of globalisation (Siamwalla 2003; Theeravit 2003). The second theme is environment as a social construct, and social relations needing to be understood with relation to specific ecological conditions and configurations - in other words, a regional political ecology. Necessarily, in dealing with such a large and complex transnational region, the analysis is somewhat coarse grained, but reference to specific local contexts and instances of contestation are brought in by way of illustrative, though certainly not fully representative, detail.

An initial description of the Mekong as a developmental entity and as a river system shows how various development and environment debates have become 
centred on these alternative discursive constructions. The chapter then examines the twin concepts of interdependent development and regional political ecology to show how the two themes associated with Brookfield's more radical work have remained separate yet provide joint pillars for a theoretical understanding of the contemporary Mekong. The remainder of the chapter uses the case of the (Greater) Mekong (Sub)Region and Basin to illustrate points of intersection between interdependency and changing society-environment relations, both in their developmental and river basin contexts, with specific reference to issues surrounding large dams, including a case study of the Se San River and the Yali Falls Dam.

\section{The Mekong as a region: developmental and river basin discourses}

The Mekong has two distinct geographical meanings as a territorial unit (Figure 13.1). First is the natural river basin, a bioregion that defines the area and whose territorial logic is bound up in physio-ecological relationships that are closely related to natural resource-dependent ways of life. Second is the wider Mekong economic region, comprising five entire countries - Burma, Cambodia, Laos, Thailand and Vietnam - and Yunnan Province of southwestern China.

Rising on the Tibetan plateau in China, flowing through six countries and discharging in Vietnam, the Mekong at 4,800 kilometres is the twelfth longest river in the world, and its annual discharge of 475 billion cubic metres ranks eighth. The basin is 795,000 square kilometres in area. (By contrast, Australia's MurrayDarling covers more than one million square kilometres but has on average only one percent of the Mekong's annual runoff. Conversely, the Mekong Basin is home to some seventy million people, some thirty-five times the number who live in the Murray-Darling. While the annual runoff of the Mekong is less variable than that of the Murray-Darling, discharge in the lower part of the mainstream typically varies approximately fifteenfold from the driest month of May to the wettest month of October.) Seasonal flood-drought cycles are a key feature of the riverine and floodplain ecology, including the human ecology of the river. The world's largest freshwater fishery, in the Tonle Sap in Cambodia, depends on land-derived nutrients available through floodplain connectivity with the river during the wet season, while riverbank cultivation during the dry season is an important source of food and income along the Mekong and many of its tributaries from China to Cambodia. This seasonality of flow simultaneously presents a significant challenge to engineers and temptation to developers, keen to control the river, harness its potential and valorise its resources - notably through hydropower development. To date, despite accelerated construction of large dams during the last decade of the twentieth century, the Mekong remains one of the less artificially regulated of the world's major river systems.

The Mekong River Basin comprises six principal biogeographical zones: Lancang River Basin; Northern Highlands; Korat and Sakon Plateau; Eastern Highlands; Lowlands; and Southern Uplands (MRC 1997, 2003). Vegetation types range from montane forests and grasslands to flooded forests, mangroves and 


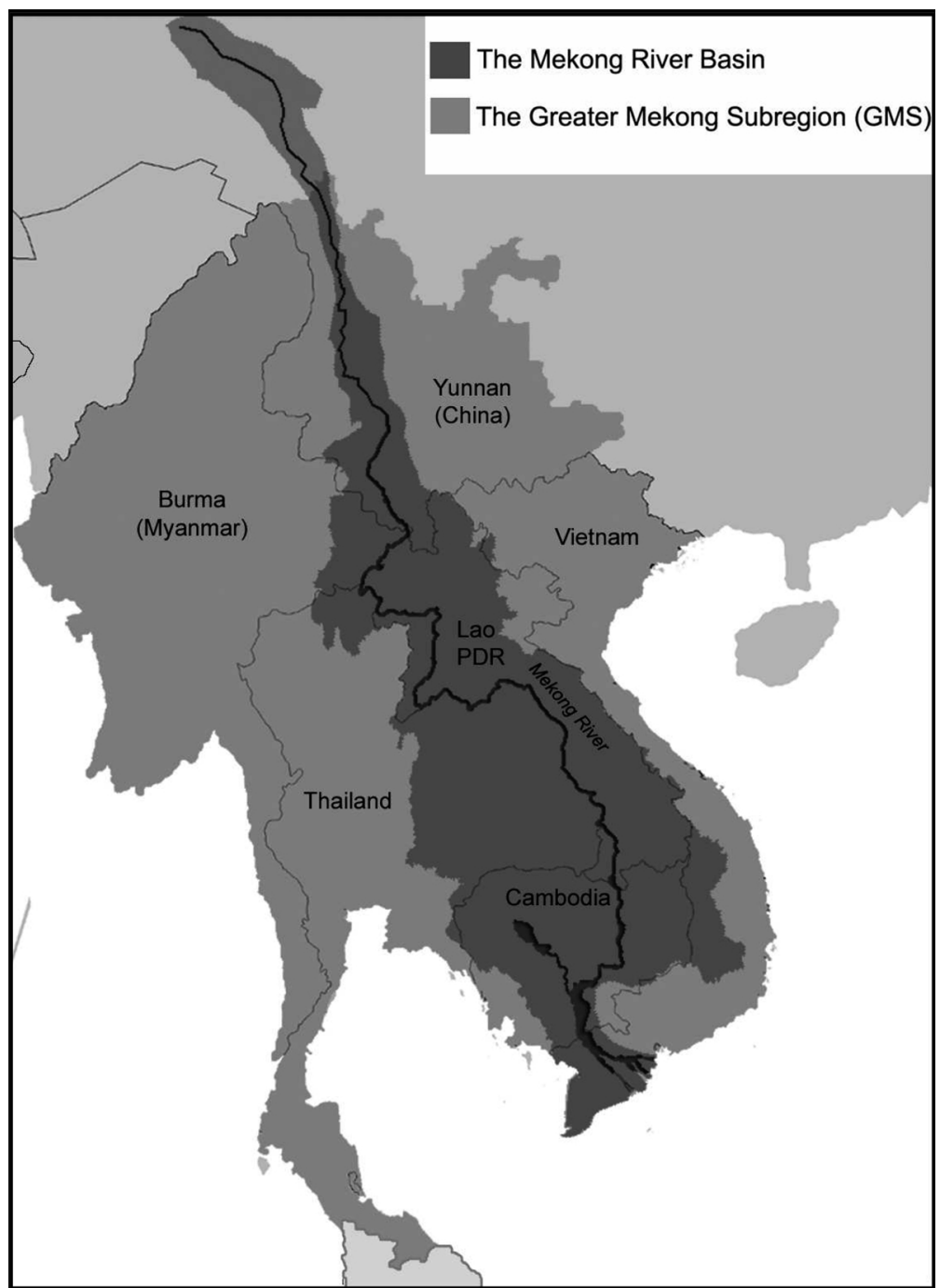

Figure 13.1 Mekong Basin and Region.

wetlands. Wetlands include the Tonle Sap system, which has been described as the 'beating heart' of the Mekong as it expands and contracts in area fourfold with the river's flood pulse, leading to the phenomenon of river reversal as the Tonle Sap River accommodates the Mekong flood toward the end of the wet season. The 1,700 or so freshwater fish species in the river are indicative of the enormously rich natural ecology of the basin, and two to three million tonnes of fish are caught annually from the river system (Sverdrup-Jensen 2002), indicating their significance in the basin's human ecology. However, the fishery also points to the vulnerability 
of subsistence-oriented production systems, dependent to a large extent on the natural resource base.

The agroecology and ethnoecology of the Mekong are highly complex. There is a broad division between upland agriculture, traditionally based in swidden practices by ethnic minorities, and lowland wet-rice systems, associated primarily with ethnic majority populations in each country (Rerkasem 2003). This characterisation of ethnoecological practices of the basin, in line with a common theme in representation of Southeast Asia (Tsing 2003), is, of course, a gross simplification and one that is intimately bound up with politics of ethnicity, policy on shifting cultivation and discourses of tribal/peasant distinctions that have questionable relevance in the twenty-first century. Further, the history of population movement and the establishment of borders through colonial and more recent geopolitical processes make it difficult to talk of indigenous groups in the same sense as is understood in settler societies, yet the uplands of the Mekong Basin are populated by groups of people with quite distinct languages, cultural practices and histories, and who are economically and politically marginalised from the dominant lowland Han Chinese, Lao, Thai, Khmer and Kinh (Viet) in their respective national contexts (Salas and Xu 2003; Chiengthong 2003).

Despite the natural basis for delineating the basin, the Mekong Region is also constructed with specific historical and geopolitical meaning. The Asian Development Bank (ADB) established a Greater Mekong Subregion (GMS) programme in 1992 (Stensholt 1997), which has since become an established department with its own integrative agenda. The first director of the GMS program, Filologo Pante, writes of the peace dividend to be reaped by regional integration (Pante 1997). Most of the GMS initiatives emphasise development through integration, and in some respects development as integration. The key components of the GMS are transport, telecommunications, energy (with an emphasis on a regional power grid), tourism, human resources development, trade, investment and environment. The ADB describes the region as 'a new frontier for economic growth' (ADB, 2006a). The documentation is ripe with excitement over potential synergies and complementarities that have to date remained untapped due to the barriers of a fragmented region:

Combined, the lands of the GMS cover about 2.3 million square kilometers. It is a vast area of enormous wealth and variety of natural resources, including a rich agricultural base, timber and fisheries, minerals, and energy in the form of hydropower and coal and petroleum reserves.... These resources fuel economic development and support rural livelihoods in an interrelated fashion. Water from the Mekong River supports agriculture, and its fish yields are a source of both protein and income. It can also be used to generate electricity and as transport corridors.

(ADB 2006b)

Other regional discourses pre-date GMS. Former Thai Prime Minister Chatichai Choonhavan in 1988 called for transformation of battlefields into marketplaces 
(plian sanaam rob pen sanaam kaan khaa). Coincidentally, this clarion call came at a moment between, on the one hand, Indochina's opening up of its economies in the various regional expressions of restructuring (Doi moi, or 'renovation', in Vietnam and Konlakai Sethakid Mai, or new economic mechanism, in Laos) and, on the other hand, Thailand's search for new sources of raw materials and energy for its own rapid industrialisation at a time when environmental politics was placing limits on logging, dam construction and other ecologically contentious activities (Hirsch 1995).

The general shift of development assistance agencies away from Thailand eastward into the countries of Indochina has also helped define the Mekong as a 'development region'. The shift came as a combination of Thailand's 'graduation' in the development stakes to a middle-income country, hence a winding down of official and non-governmental organisation (NGO) development assistance through both conscious decisions and more automatic triggers, and the increasing political acceptability of increasing financial support to Vietnam and Cambodia after the political changes in the latter from 1991 onward. In the mid-1990s, the Australian official development assistance agency, AusAID, established a Mekong regional program as part of this process, as did a number of bilaterals and also the World Bank in 1997 through its Mekong Project Development Facility.

The Mekong as a region of five countries and Yunnan Province in China has a population of some 250 million and only a loose association with the river itself. However, the Mekong Basin (Figure 13.1) as a revived focus for regionalisation is centred on a bioregion that is home to 70 million people, the great majority of whom rely to a greater or lesser extent directly on the river, its tributaries and its land-based and water-based resources for agricultural, fishing and forest-based livelihoods. This is also a region whose principal linking resource, the Mekong River itself, has been targeted for hydropower development. The December 1968 cover feature of National Geographic featured 'The Mekong: River of Terror and the Hope'. The terror of the time was the 'Communist menace'. The hope was the promise of a cascade of large dams bringing regional prosperity. Regional geopolitical conflict kept these dams off the development agenda long enough for ecopolitical concerns to force reconsideration of the larger projects when they were resurrected after the regional rapprochement of the late 1980s.

Bioregional integration in the Mekong is focused institutionally on the new incarnation of the longstanding framework for cooperation under the Mekong Committee, in the form of the Mekong River Commission (MRC). Based on an agreement signed between the four lower riparian countries in 1995, the MRC development discourse is couched in terms of sustainability and mutual benefit in a rather less developmentalist approach than the hydropower-dominated agenda of the old committee:

When the Mekong River Commission replaced the Mekong Committee in 1995, the focus changed. MRG was established as a river basin management organization, with as much emphasis placed on sharing resources equitably and sustaining the environment as on developing resources.

(MRG 2003: 205) 
However, the realpolitik of development is such that dams are very much back on the agenda; in part following plans for tributary developments, such as Yali Falls in Vietnam (Electrowatt 1993) and the proposed Nam Theun 2 Dam in Laos (Hirsch 2002), the blueprints for which date from studies commissioned by the secretariat that now in restructured form serves the MRC. In 2001, MRC adopted a hydropower development strategy that 'treats hydropotential as one of many renewable natural resources and considers both the benefits and the adverse consequences of hydroelectric development' (ibid.).

The mainstream Mekong development agenda is seen by critics as elite-centred, as potentially as polarising as it is integrative, and as one that is shifting geopolitical conflict into a new arena of ecopolitical conflict. In response, a number of NGOs have constructed an alternative Mekong regional development discourse. Several Oxfams that work in one or more countries in the Mekong (including Oxfam Community Aid Abroad, Oxfam GB, Oxfam Hong Kong, Novib and Oxfam Solidarity) have grouped their efforts into an Oxfam Mekong Initiative (OMI). OMI has the dual approach of supporting small scale alternative village-based development schemes and of engaging in advocacy and policy-level work in respect of some of the regional approaches that are seen as threatening to the well-being and livelihoods of the poor, marginalised ethnic minorities and women.

Thailand's nascent environmental movement was quick to pick up on the destructive potential of expanding the peripheral resource economy across the country's borders. One of the environmental NGOs that had played a pivotal part in the successful campaigns to cancel Nam Choan Dam in 1988 and to rescind the country's logging concessions in 1989, the Project for Ecological Recovery, established a sister organisation, Toward Ecological Recovery and Regional Alliance (TERRA), in 1990 specifically to monitor the extension of Thailand's socially destructive and ecologically unsustainable development path in the wider Mekong region. TERRA's publication Watershed has documented and advocated on many aspects of this, including dams, irrigation and plantations of exotic trees such as eucalyptus, as well as printing more generalised critiques of various aspects of a fasttrack growth-oriented capitalist approach to development. TERRA's critique is encapsulated in an editorial:

The creation of social conflicts, the destruction of local economies and the natural environment, and the immiseration of innumerable victims is the legacy that the $\mathrm{ADB} / \mathrm{GMS}$ is developing. While the $\mathrm{ADB} / \mathrm{GMS}$ trumpets inter-state cooperation as the foundation for peace, the people actually living and working in the countries of the Mekong Region are demanding something much different, much more profound and much more promising. Their concerns are about $\mathrm{ADB} / \mathrm{GMS}$ projects that displace people, remove their rights over local resources, destroy and pollute the environment and undermine food security and a model of development that undermines national and local processes for decision making.

(Watershed, July-October 2003: 3)

More specifically focused on rivers, the Southeast Asia Rivers Network (SEARIN) 
likewise has its base in Thailand and origins in Thai activism, but it extends its area of attention to the Mekong River system and other rivers (notably the Salween) in the wider region. Increasingly, China's growing environmental movement is becoming interested in issues around dams, and the Lancang Jiang (Upper Mekong) and $\mathrm{Nu}$ Jiang (Upper Salween) have become focal points in hydropower development.

Other organisations with environmental and developmental roles at a wider level have also homed in on the Mekong. While they are too numerous to deal with in full, they include: FOCUS on the Global South, established by globalisation critic Walden Bello, whose Mekong programme brings the global civil society analysis to a regional level; the International Rivers Network (IRN), the leading global anti-dam NGO; the World Resources Institute, whose Resources Policy Support Initiative (REPSI) has brought a more mainstream environmental NGO into the regional arena around the theme of regional environmental governance (REPSI 2001); and academic groupings such as the triennial conference Montane Mainland Southeast Asia in Transition, concerned with the commonalities and linkages of regional change as it affects the upland peripheries. Academic initiatives on the Mekong include regional centres within Thailand at Chiang Mai, Khon Kaen, Ubonratchathani and Chulalongkorn Universities, in Vietnam at Can Tho University and outside the region at the Australian Mekong Resource Centre at the University of Sydney.

Why has the Mekong become such an iconic region? At one level, the very scale of the river system - one of the world's largest - helps to explain the attention given to it. However, a more substantial explanation lies elsewhere and is as much in the metaphoric as in the substantive significance of the symbolism of linkage, interdependence and the complex interaction between societal and ecological change bound up in the region's development agenda. To a substantial extent, the region as an arena of contestation has come to be defined as forcefully by competition in the discursive realm of ideas about development as in the realm of competition over material resources.

\section{Interdependence, political ecology and contested development}

The Mekong, then, is an increasingly interdependent region and one defined in terms of contested development directions and contested societal relations over environmental resources. A reading of Harold Brookfield's work on Interdependent Development (Brookfield 1975) and on regional political ecology, as expounded in his shared work with Piers Blaikie on Land Degradation and Society (Blaikie and Brookfield 1987), should shed some light on the relationship between these two defining aspects of region. Yet in Brookfield's own writings, there is little immediate or obvious point of connection between these two works - indeed, there is no reference to the former in the extensive bibliography of the latter - which have been among the more radical, most seminal, and for myself the most formative of Brookfield's works. 
Interdependent Development is, as the jacket and the foreword state clearly, a book about ideas about development rather than about development outcomes. The key idea underlying Brookfield's review of mainly non-geographical thought on development is that development and underdevelopment do not respectively shape different parts of the world, as is common in the Third World-ism that Harris (1986) and others were later to question. Rather, development is itself an integrative process and phenomenon - and, I would add, an incorporative one (Hirsch 1990). In other words, interdependence is a process that is forged by, but also defines, the condition of development. Separate worlds with little to connect them do not represent the conditions of development and underdevelopment; they are something else entirely. A region integrating is a region developing, but this does not, by definition, mean a region in which progress in human well-being is universal or even positive in a net sense - hence the Mekong is a 'development region' irrespective of different standpoints on the desirability of the dominant development directions. Polarisation and marginalisation can equally be outcomes of development, though again not necessarily so. Thus, interdependent development in Brookfield's terms is far from teleological; there is much that is contingent historically, spatially and ecologically.

Ecology is the starting point of Land Degradation and Society, but environmental degradation as a problem is not defined ecologically. Like the idea of nature itself, the phenomenon of degradation, as well as its causation, is fundamentally a social construction, one with strong historical resonance in Southeast Asia, and one that is part of wider socio-political relations between states and subject peoples (Greenough and Tsing 2003). Moving beyond a physically defined, essentialised approach to environmental degradation points us toward two key societyenvironment interplays.

First, environmental change is only defined as degradation in social terms, in other words with respect to its harmful impact on, or loss of values for, society as a whole or for particular societal or geographically defined groups. Not surprisingly, the social science of environmental degradation thus becomes defined around the structures of class, gender, ethnicity and place that determine cost, benefit and risk that are part of socially constructed processes of environmental change associated with development and modernisation.

Second, environmental change that is socially defined as degradation also has social causation at its base. With the assistance of his co-author's immediately proceeding seminal work (Blaikie 1985), Brookfield addresses the longstanding scientistic monopolisation of causality to show a reflexive relationship between society, environmental change and impact. People cause change, not just as organisms populating the planet, but also through social process, conscious management, culture, structures of society, economy and politics - all of which are subject to rapid change in the processes of development and modernisation.

It is the last aspect of land degradation and society that suggests a full-circle relationship between the two works under discussion, as interdependence through integration redefines and re-scales society-environment relations. Further, this relationship can be understood with reference to any specific regional context, 


\section{Philip Hirsch}

which I propose in the remainder of this chapter to explore further with reference to the Mekong. Land Degradation and Society goes some way towards this through its discussion of regional political ecology (1987: 17 ff.). However, Blaikie and Brookfield introduce this as a rather sketchily defined approach, but one which more recent developments in political ecology help move toward a region-defining paradigm (Bryant and Bailey 1997; Walker 2003).

\section{Regional integration and new interdependencies in the Mekong}

The integrative development agendas of the Mekong foster a range of new interdependencies. Margins are redefined, as for example Thailand's Northeast (Isan) moves from peripherality in its national context to an imagined centrality in the context of Mekong regional development. The National Economic and Social Development Board adopted this repositioning in its five-year plans (e.g. NESDB 2002: 55), and provincial chambers of commerce focus on cross-border opportunities along the length of the Thai-Lao, Thai-Burma and Thai-Cambodia borders. Meanwhile, new forms of marginalisation are inherent in this process, as resource development that is integral to Mekong development displaces livelihoods. In Blaikie and Brookfield's terms (1987: $19 \mathrm{ff}$.), there is a shift from economic marginalisation (also in the sense of spatial economic periphery) toward politicaleconomic marginalisation, in part through the creation of ecological marginality. The Pak Mun Dam is a case in point, as hydropower development has decimated local fisheries and contributed to a social movement in protest against the government's development agendas more widely (World Commission on Dams 2000; Missingham 2003). Consequently, the ironic re-imagining of Isan from peripheral and neglected region to one subject to the ravages of fast-track development is heard in voices of resistance that increasingly frame their critique of the social and environmental consequences of Isan's development with reference to the wider Mekong development agenda (e.g. SEARIN 2004).

New transport routes are both symbolic and substantive arteries of integration. Australia and Japan's bilateral development agencies have not missed the symbolic potential of bridges: in 1994 Australia funded the first bridge across the Lower Mekong, between Thailand and Laos; Japan soon followed suit at Pakse; Australia's largest ever aid project straddles the Tien Giang branch of the Mekong in the Mekong Delta at My Thuan; Japan is trumping this with one bridge between Mukdahan in northeast Thailand and Savannakhet in Laos and another across the other main branch of the Mekong in the delta, the Hau Giang, to complete the road link between the delta's capital, Can Tho, and the rest of Vietnam (Figure 13.2).

While borders remain closed to large scale labour migration, estimates of the number of legal and illegal migrant workers in Thailand from Burma, Laos and Cambodia range from about one million to two million (Bangkok Post, 8 July 2003; Chalamwong 1998). This is despite the economic downturn post-1997. Vietnamese migrants in Laos remain a sensitive subject in that country, as they 


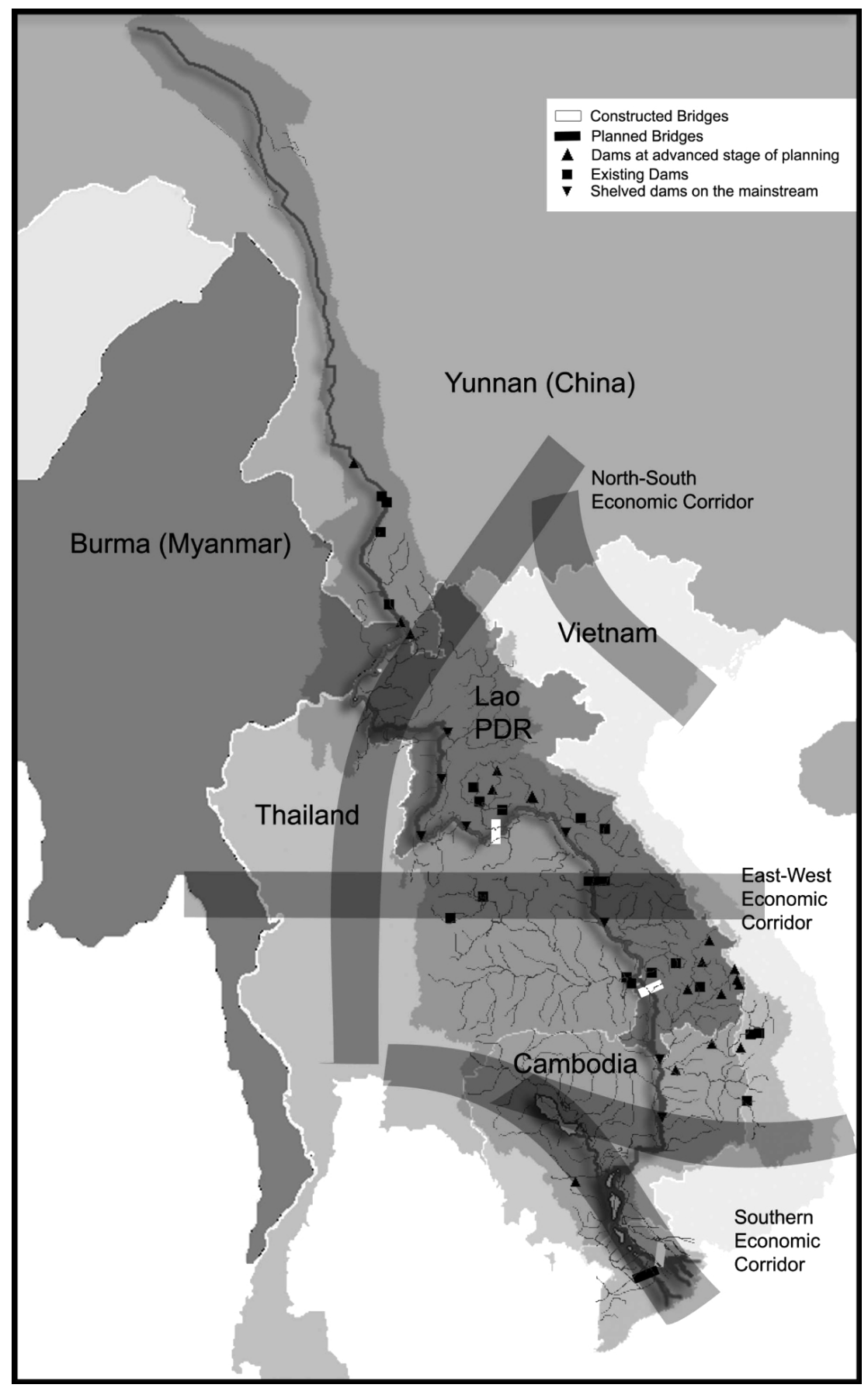

Figure 13.2 Greater Mekong Subregion infrastructure. 
have taken up positions in petty trading and construction work and employment in other key areas.

Tourism has employed the river in its 'Jewels of the Mekong' theme, both to promote international travel to and within the region and to build up a nascent intraregional tourism market (see the Pacific-Asia Travel Association website: www.travelmedia.com/mekong). The latter mainly involves Thai travellers to key sites within the region, notably Angkor Wat in Cambodia, Luang Prabang in Laos and Xishuangbanna autonomous Tai region in Yunnan. All of these are served by direct flights from Thailand.

Hydropower development retains by far the highest profile in regional integration and interdependency. Significant cross-border sale of electrical energy in the Mekong dates from completion of the Nam Ngum Dam in 1971. However, the scale of actual and proposed energy linkage has increased with the GMS vision of an integrated energy grid, supported by technical assistance from the ADB and materialised through a number of hydropower projects - mostly in Laos - for sale of electricity to Thailand. The Huai Ho, Xeset, Nam Theun Hinboun, Nam Leuk and Nam Song Dams have already been completed to this effect, and the giant Nam Theun 2 project has been at the centre of complex negotiations involving electricity sales, cross-investment and loan guarantees from the World Bank's Multilateral Investment Guarantee Agency (Hirsch 2002; Figure 13.2).

The framework for cooperation and the thrust of economic integration in the Mekong has long been focused mainly on the lower Mekong countries of Thailand, Vietnam, Laos and Cambodia. However, China is rapidly extending its geopolitical and economic influence through the region, and the cascade of dams under construction on the Lancang Jiang carries great significance for the hydrology of the river and for livelihoods in downstream countries (McCormack 2001). While China has been outside the Mekong Committee and MRC framework, this may change with a renegotiated agreement. Yunnan Province in China is also a key player in the GMS initiative. Civil society voices are expressed through Chinese NGOs such as Green Watershed, and even the strongly governmentoriented Asian International Rivers Centre at Yunnan University has urged caution in hydropower development along the $\mathrm{Nu}$ Jiang. Numerous formal and informal networks and initiatives now link China with development agendas in the lower Mekong countries.

In the Mekong, then, there is an increasingly interdependent development trajectory - bearing in mind Brookfield's notion of development as an idea and a relational concept rather than as a predefined end state. It is worth recapitulating Brookfield's reminder that while 'the popular trend is to define development in terms of progress toward a complex of welfare goals, such as reduction of poverty and unemployment, and diminution of inequality', development is in fact 'the whole process of change brought about by the creation and expansion of an interdependent world system', incorporating both positive and negative aspects (1975: xi). In the construction of the Mekong as a development region, interdependencies are part of specific positive institutional visions for the region in which different countries' complementarities (labour, natural resources, capital) are exploited for 
mutual benefit. The discourse goes further, however, in the form of an ideal in which a region recently divided by hot and cold war can use economic interdependence as a means to forge joint prosperity and an interwoven economic destiny. Further, convergence of economic paradigms places this scenario within a neoliberal economic framework of openness and marketisation. Needless to say, the counter-critique engages this vision vigorously, with a host of social and ecological questions about the negative side of the interdependent development equation.

\section{Society and environment in the Mekong}

The integrative development agenda in the Mekong has placed pressure on natural resources, particularly in peripheral, upland areas whose accessibility has been increased through new transport links, cross-border demand and access to finance capital for dams, mines and other large resource developments. Thailand's demand for timber and other forest products and for fish and for energy has been met with increasing ecopolitical constraints on resource exploitation within the country's borders (Innes-Brown and Valencia 1993, Hirsch 1995).

Dams have become a primary arena for contested development in the Mekong. Hydropower has been important symbolically as a marker of modernity and development, and materially dams are a means of valorising a river's resources to generate energy and financial returns from economic activity at sites far removed from the point of resource development. Dams are also in and of themselves the single most significant impact on the natural ecology of a river system (McCully 1996). They similarly have major impacts on human ecology, so that it is difficult to consider environmental impact independently from social impact where the livelihoods of the majority - and especially of the poor and more marginalised are directly dependent on the natural resource base (Hirsch and Warren 1998). There is thus an inherently dramatic geography of cost and benefit associated with large dams.

Dam construction in the Mekong Region is hardly new (Hirsch 1996), but the regional development agenda has given a new lease of life to Mekong hydropower development in an era when large dam construction has been on the decline elsewhere and has been subject to critical review, most notably through the World Commission on Dams - which took the Mekong as one of its key case studies (World Commission on Dams 2000). A number of recently built dam projects have become highly controversial, notably: the Yali Falls on the Se San River in Vietnam, which has had devastating downstream impacts on indigenous communities $^{1}$ in northeastern Cambodia (Hirsch and Wyatt 2004); the Theun-Hinboun Dam in Laos, with impacts both on the Theun River and on the smaller Mekong tributary into which the dam diverts water (Warren 1999); the Pak Mun Dam in Thailand (World Commission on Dams 2000); and the two completed dams on the Lancang-Mekong mainstream in Yunnan, which are part of a cascade of eight dams to be completed by 2020 (McCormack 2001). Furthermore, a number of projects are under construction, including the world's equal tallest dam structure at 
Xiaowan (at 300 metres it is as high as the Eiffel Tower) and Jinghong Dam on the Lancang-Mekong mainstream, and the Se San 3 dam in Vietnam, just downstream of Yali Falls, while a range of controversial projects such as Nam Theun 2 keep dams very much at the forefront of controversy over the Basin's environmental and development future. The complexity of the immediate and local social and ecological transformations associated with these projects is matched by a highly diverse landscape of decision-making and negotiation among a myriad of actors. These actors range from remote, isolated upland shifting cultivators to international NGO networks and corporate players in a now partly privatised hydropower industry that nevertheless relies on subsidies and guarantees from state and global players, including the World Bank and the ADB. Societal relations around dam controversies are thus part and parcel of regionalised and globalised processes reflecting an interdependence that goes well beyond the more familiar axes of tension and negotiation within national borders (Hirsch 2001).

Similar contestation marks the regionalised exploitation of other resources. The same indigenous minorities in northeastern Cambodia who have suffered the impacts of Yali Falls Dam are subject to depredations on their resource base by loggers (Witness 2002). They are yet further constrained in their resource access by establishment of the Virachey National Park with the support of the World Bank. The wider context of protected area expansion is a source of tension between forest-dependent livelihoods and regional projects, often supported through bilateral and multilateral development assistance to promote sustainable development (Vandergeest 1996).

Upland ethnic minorities have been affected disproportionately, for a number of reasons. Resource tenure systems in the uplands are poorly defined, and most of the forest, land and water resources on which uplanders depend are formally state property. Expansion of resource projects and accessibility of previously isolated areas thus lead to encroachment on customary use and tenure systems. The absence of formal property rights in subsistence-orientated upland farming and agroforestry systems leaves them particularly vulnerable to external appropriation and valorisation of the resource base. Furthermore, the socio-political position of many minority peoples is quite tenuous, due to cultural prejudices (notably in Vietnam and Cambodia, where the majority Viet and Khmer peoples often view minorities as less than fully civilised), to isolation and limited options for involvement in affairs of state (for example in the isolated mountainous peripheries of Laos and Yunnan), to armed conflict between border minorities in Burma, and to lack of citizenship or resource rights for many 'hilltribe' people in Thailand. The distinctive culture and human ecology of the latter is reflected in the Thai term 'chaokhao', which puns descriptively as 'mountain people' and in a vernacular expression of otherness as 'them people' (in contrast to 'chaorao' or 'us people').

Changing society-environment relations in the Mekong is marked by two key trends. First, environment has emerged as a significant category at a societal level as well as in the context of more specific development project considerations; and as it has done so it has also become an increasingly differentiated and contested category (Hirsch 1997, Tim 2003, Greenough and Tsing 2003). In other words, the 
debate in the Mekong has moved well beyond the 'environment versus development' axis, towards epistemological questions of local versus expert knowledge in areas such as fisheries, and toward bifurcations between livelihood-oriented and straight conservation-oriented environmentalisms. Second, and related to this trend, is a regional up-scaling of societal concern with the environment to a regional level in recognition of transboundary environmental implications of development (Khaosa-ard and Dore 2003), so that the Mekong is defined in part as a region of contestation over appropriate developmental directions.

To what extent can we then go back to Blaikie and Brookfield's (1987) notion of regional political ecology to understand the river basin as a field of social relations and specific interactions and dialectics between society and ecology? Not surprisingly, given the nearly two decades of work in political ecology and related fields since this seminal volume, only to a limited extent. The original notion of regional political ecology was twofold. First, it gave empirical and specific context to land degradation studies, reminding us that environmental variability is important in warning against a universalistic approach or formula for understanding society-environment interactions. Second, it drew on the core-periphery model to emphasise the specific circumstances of peripheral 'regions'. As such, a bioregion such as the Mekong, which is itself so internally environmentally diverse and incorporates both cores and peripheries (though more of the latter in the absence of a major urban centre), is of a different scale from the regional level of resolution that Blaikie and Brookfield probably had in mind. However, when the notion of interdependence is brought back into consideration, a regional political ecology of the bioregion starts to make a lot more sense. In other words, a useful lens for understanding the Mekong Basin as a region is to view it precisely as a field of society-environment relations, incorporating spatial and social core and peripheral places and voices respectively. The very issue of diversity and scale of resolution for appropriate management itself becomes an issue of contention, with scale-defined tensions between the local and the super-region.

\section{Givil society participation, governance and interdependency}

The growing incorporation of peripheries into the cultural, economic and development mainstream presents those who challenge the more inequitable and unsustainable paths to development with a number of dilemmas. On the one hand, there is a degree of opening of political space in all countries to match the rapidly diversifying societal and economic structures, in line with a generally more open environment for 'civil society' - that is, non-governmental organisations and other forms of social mobilisation, articulation of non-commercial societal interests and collective action outside the framework of the State. On the other, incorporative development associated with linkage can be disempowering at a local level (Hirsch 1990), despite the many moves toward decentralisation of natural resource management and governance more generally (REPSI 2001; Edmunds and Wollenberg 2003). Moreover, civil society in the Mekong remains a highly differentiated entity, 
and there is a degree to which successful critique and empowerment in some parts of the region (notably Thailand) have not so much altered as relocated the more exploitative resource extraction and social dislocation associated with logging, dam building and other activities that are no longer accepted without question by those most affected by them.

Thailand has a history of critical response to elite development paradigms, dating from the student-led overthrow of the dictatorship in 1973. However, it has mainly been since the 1980s that the NGO sector has flourished, particularly with the demise of the Communist movement as the most significant oppositional force. Environmentalism became both a coalescing and legitimising discourse of opposition to dams (notably the Nam Choan case in the 1980s), to logging and more generally to the fast-track growth that has marked Thailand's development at high social and environmental cost (Bello et al. 1998; Phongpaichit 1998).

While Vietnam, China and Laos have all gone through significant transformations from centrally planned socialist economies toward more decentralised market-oriented production, there has not been a concomitant opening of political space or room for critique in as open a manner as in Thailand. NGOs that do voice significant concern over projects such as Yali Falls, Nam Theun 2 or Xiaowan Dam, or blasting of the rapids on the upper Mekong to make way for navigation, tend to be international NGOs, who nevertheless must tread carefully. Green Watershed and other NGOs in China lend a domestic voice to such concerns, and these have been strengthened by support from some key state agencies - notably the State Environmental Protection Authority. Cambodia, meanwhile, has seen a rapid opening up of space for local NGOs to voice concern, and in Ratanakiri in particular there is a strong movement among adversely affected communities that has quite successfully articulated through and with local government (Hirsch and Wyatt 2004).

Civil society in the Mekong thus remains a complex and inchoate category. International development agencies, including the bilaterals and the MRC and the $\mathrm{ADB}$, pay increasing attention to governance issues, but they work well within the existing limits of what is officially sanctioned within each country. Interdependent development of the Mekong thereby remains a somewhat skewed process, in the sense that the increased porosity of borders, mingling of leaders and exploitation of complementarities remain an elite agenda. Conversely, the region is increasingly defined by contestation and grassroots linkages that cross national borders, particularly in the realms of resource governance and in socio-environmental critiques of mainstream developmentalism.

Thus, emergence of civil society in the Mekong in response to transnationalisation and mainstream development agendas marks both the potentials and dilemmas associated with ever-growing interdependence and the moving centrestage of society-environment questions in local, national and supranational regional discussions and debates over appropriate development directions. It is here, in part, that Brookfield's twin insights can be brought together to help inform issues of governance and sustainability. 


\section{Interdependency and regional political ecology: Se San dams}

In March 2000, some two months prior to the end of the dry season, villagers along the Se San River in northeastern Cambodia experienced catastrophic and unseasonal flooding, despite no untoward weather conditions. At least thirty-two people drowned, boats and livestock were washed away, riverbank gardens were destroyed and villages were flooded. This followed less extreme fluctuations in water levels intermittently since 1996. The initial response of the Brou, Tampuan, Lao, Jarai and other mainly animist ethnic minorities living in this area was to sacrifice livestock to propitiate seemingly angry spirits. News of the Yali Falls Dam, experimental water releases from which were in fact causing these events, only slowly filtered through to the isolated communities. The 2000 events galvanised villagers' responses. With the support of a local NGO that had been mobilising around access to non-timber forest products in Ratanakiri Province, communities established a network that attracted support from Oxfam and a host of other Cambodian civil society groups and international NGOs working in the fields of development, environment and human rights.

The Se San River is a significant tributary of the Mekong. The headwaters rise in the Central Highlands of Vietnam, and the river flows westward into Cambodia, traversing the province of Ratanakiri, to its confluence with the mainstream in Stung Treng Province (Figure 13.3). Villagers living along the river mainly practice rotational swidden cultivation, collect forest products and fish in the Se San. Until unpredictable water levels made it too dangerous to do so, several villages also relied on gold-panning on sandbanks to supplement their meagre cash incomes. All of these activities have been severely curtailed by the flooding.

Following initial responses, the Se San Protection Network (SPN) was established to document the impacts and press for more responsible operation of Yali Falls Dam. Other demands that have been articulated through SPN include a halt to plans for a total of six dams on the upper Se San, given the impact of just one. In particular, the Se San 3 dam has become a focus of attention. Originally designated for support by the ADB, this dam is now entirely a Vietnamese project, following a decision by Electricity of Vietnam $(\mathrm{EVN})$ to go it alone after the ADB placed further environmental assessment conditions for its support, in response to international NGO concerns. Since the impact in question is transboundary, the Se San has also become an issue involving MRC. MRC has established a formal government-to-government committee, but has refrained from becoming involved at a more immediate level, to the frustration of the communities involved. To date, Cambodian representatives on the joint committee have been unable or unwilling to press for restitution, change in operating regime or reconsideration of the largescale hydropower development plans for the river. Successes have been achieved in improving early warning of water releases, but the isolation of the affected communities has continued to preclude timely advice on emergency spills.

Details of the Se San case have been documented elsewhere (Hirsch and Wyatt 2004). The key points to note here are that ethnicity, power, resource access and 


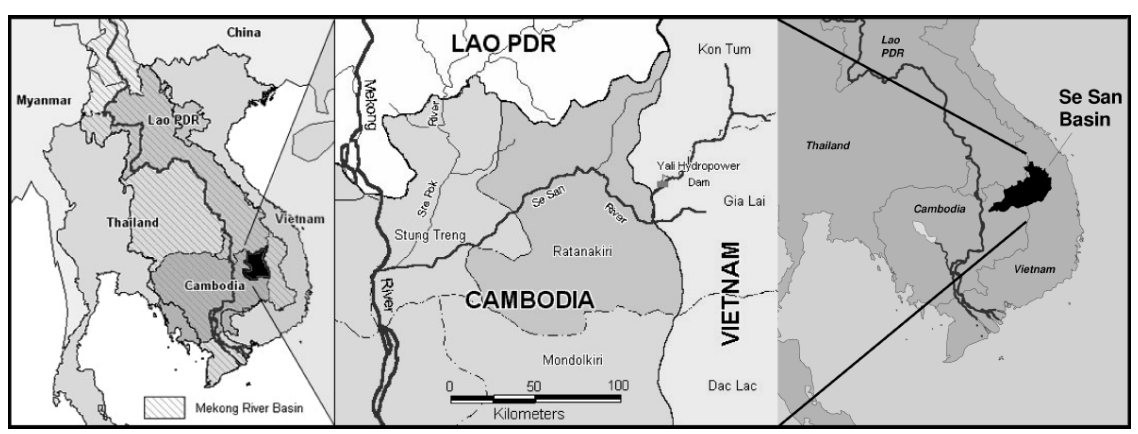

Figure 13.3 Se San Basin, Cambodia.

emerging civil society forms are all bound up with agendas of regional integration - even in the most remote peripheries of the region. The Janus face of interdependency for impacted communities and their civil society allies emerges in sharp relief through this case. On the one hand, the marginalisation caused by the transboundary impacts of Yali Falls Dam are part and parcel of an integrative regional development agenda. On the other hand, the opportunities to scale up responses by isolated communities is afforded by a regionalising civil society, by new political spaces and by a development ethos that at least pays lip service to accountability for impacts at the transboundary bioregional level. The Se San experience also demonstrates where political ecology goes beyond the local in understanding the rapidly changing interaction between society and ecology; some of the region's most isolated communities are now bound up in environmentdevelopment debates that resonate at all levels. The success of the SPN in mobilising community interests and feelings also reminds us of the potentials and significance of local agency and of the need to move beyond an overly structuralist and fatalistic core-periphery understanding of interdependence and regional political ecology.

\section{Conclusion}

In its alternative geographical manifestations - development region and river basin - the Mekong provides a context for examining the significance of two seemingly disparate sets of ideas emanating from Brookfield's work. However, this chapter sets out not so much to take a retrospective look at this work as to shed light on how we can better understand alternative - and to some extent competing constructions of region. The geographical representations outlined in Figure 13.1 have resonance with interdependent development and regional political ecology respectively, but this resonance is really only a starting point.

In a more holistic sense, the chapter has sought to present a framework for a regional political ecology of the Mekong that incorporates key themes in interdependent development. The aim and outcome is an understanding of the Mekong as a region constructed around particular integrative material processes and 
discourses and their contestation on the basis of competing agendas and visions regarding the ecological and societal futures for the river basin and the wider region of which it is a part. This construction of region as a field of society-environment relations is thus governed by challenges to the regionalism of the $\mathrm{ADB}$ and to a macrodevelopment agenda left over from the developmentalist Mekong Committee. Many of the ideological encounters are marked by confrontation of currents more commonly associated with the globalisation arena. Yet, at the opposite end of the scale, challenges also take specific and local forms, as epitomised in the case of the Se San dams, as this local and peripheral case has been drawn into wider currents. A rescaling of interdependencies and challenges is thus integral to the regionalisation of the development agenda.

This therefore takes Blaikie and Brookfield's regional political ecology beyond the notion of combining 'the concerns of ecology and a broadly defined political economy' that 'take[s] account of environmental variability and the spatial variations in resilience and sensitivity of the land' or 'incorporate[s] ... environmental considerations into theories of regional growth and decline' (1997: 17), to a regional political ecology in which interdependence is a central theme and in which contestation in the realm of both ideas and asserting rights over resources and their management play a fundamental part. This approach also shows the potential of bioregionalism in a river basin framework to frame such a regional political ecology (cf. Powell 1993).

What does this bringing together of two of Brookfield's key ideas tell us about development and governance of a river basin such as the Mekong? A particularly significant reminder from Brookfield's earlier work is the need to keep a focus on the realm of ideas about development, but not to see this as simply an academic exercise. Civil society challenges have been most effective and most powerful when and where they have questioned key paradigms. It is in the realm of societyenvironment relations, in building a social science that incorporates a recognition that environmental issues are about more than finding a techno-fix, that some of the most robust challenges to, and brakes on, an otherwise dominant development juggernaut have emerged. Some of these challenges in the Mekong are universitybased, such as the Regional Social Science Centre for Sustainable Development at Chiang Mai University. Others are NGO-based, such as Oxfam's Mekong Initiative, or the Foundation for Ecological Recovery's TERRA initiative, or the Southeast Asia River Network. Brookfield's reminder to these initiatives is twofold: not to lose sight of the natural and human ecology that underpins the contestations inherent in political ecology, and not to fall into the autarchic or isolationist trap that overlooks the interdependence that is a defining feature of development.

\section{Note}

1 In this case, the term 'indigenous' is quite accurate in the sense that the Mon-Khmer groups of Vietnam's Central Highlands, southern Laos' eastern uplands and northeastern Cambodia's uplands historically pre-date the colonial and post-colonial states that asserted territorial control over these areas and the settlement of Kinh, Lao and Khmer, who have more recently laid claim to the area's timber, land and riverine resources. 


\section{References}

ADB (Asian Development Bank)(2006a) wrew.adb.org/Documents / Brochures/GMS_Connecting Nations/link_people.asp.

$\operatorname{ADB}$ (2006b) wrw.adb.org/GMS/about.asp.

Bello, W F, Cunningham S and Poh L K (1998)A Siamese Tragedy: Development and Disintegration in Modern Thailand, London: Zed Books.

Blaikie, P (1985) The Political Economy of Soil Erosion in Developing Countries, London: Longman. — and Brookfield, H (1987) Land Degradation and Society, London: Methuen.

Brookfield, H (1975) Interdependent Development, London: Methuen.

Bryant, R L and Bailey, S (1997) Third World Political Ecology, London: Routledge.

Chalamwong, Y (1998) The impact of the crisis on migration in Thailand, Asian and Pacific Migration fournal, 7(2-3), 297-312.

Chiengthong, J (2003) The politics of ethnicity, indigenous culture and knowledge in Thailand, Vietnam and Lao PDR, in M Khaosa-ard and J Dore (eds), Social Challenges for the Mekong Region, Chiang Mai: Social Research Institute, Chiang Mai University, pp. 148-72.

Edmunds, D and Wollenburg, E (eds) (2003), Local Forest Management: The Impacts of Devolution Policies, London: Earthscan.

Electrowatt (1993) Environmental and Financing Studies on the Yali Falls Hydropower Project (Basin wide), volume 1, executive summary, Bangkok, Mekong Secretariat and Ministry of Energy, Socialist Republic of Viet Nam.

Greenough, P and Tsing, A (eds) (2003) Nature in the Global South: Environmental Projects in South and Southeast Asia, Durham, NC: Duke University Press.

Harris, N (1986) The End of the Third World: Newly Industrializing Countries and the Decline of an Ideology, London: Tauris.

Hirsch, P (1990) Development Dilemmas in Rural Thailand, Singapore: Oxford University Press.

- (1995) Thailand and the new geopolitics of Southeast Asia: resource and environmental issues, in J Rigg (ed.), Counting the Costs: Economic Growth and Environmental Change in Thailand, Singapore: Institute of Southeast Asian Studies, pp. 235-59.

(1996) Large dams, restructuring and regional integration in Southeast Asia, Asia Pacific Viewpoint, 37, 1-20.

-(ed.) (1997) Seeing Forests for Trees: Environment and Environmentalism in Thailand, Chiang Mai: Silkworm Books.

-(2001) Globalisation, regionalisation and local voices: the Asian Development Bank and re-scaled politics of environment in the Mekong Region, Singapore Fournal of Tropical Geography, 22, 237-51.

-(2002) Global norms, local compliance and the human rights-environment nexus: a case study of the Nam Theun II Dam in Laos, in L Zarsky (ed), Human Rights and the Environment: Conflicts and Norms in a Globalizing World, London: Earthscan, pp. 147-71.

— and Warren, G (eds) (1998) The Politics of Environment in Southeast Asia: Resources and Resistance, London: Routledge. and Wyatt, A (2004) Negotiating local livelihoods: scales of conflict in the Se San River Basin, Asia Pacific Viewpoint, 45, 51-68.

Innes-Brown, M and Valencia, M (1993) Thailand's resource diplomacy in IndoChina and Myanmar, Contemporary Southeast Asia, 14, 332-51.

Khaosa-ard, M and J Dore (eds) (2003) Social Challenges for the Mekong Region, Chiang Mai: Chiang Mai University. 
McCormack, G (2001) Water Margins: Development and Sustainability in China, AMRC Working Papers, Sydney: Australian Mekong Resource Centre, University of Sydney.

McCully, P (1996) Silenced Rivers: the Ecology and Politics of Large Dams, London: Zed Books.

Missingham, B (2003) The Assembly of the Poor in Thailand: From Local Struggles to National Protest Movement, Chiang Mai: Silkworm Books.

MRC (Mekong River Commission)(1997) Seminar on integrated river basin development and management focusing on environment aspects and public participation. Cha-Am, Thailand. Phnom Penh: MRG.

_-(2003) State of the Basin Report 2003, Phnom Penh: MRC.

NESDB (National Economic and Social Development Board)(2002) Ninth National Economic and Social Development Plan (2002-2006), Bangkok: NESDB.

Pante, F (1997) Investing in regional development: the Asian Development Bank, in B Stensholt (ed.), Developing the Mekong Subregion, Melbourne: Monash Asia Institute, pp. 16-21.

Phongpaichit, P (1998) Thailand's Boom and Burst, Chiang Mai: Silkworm Books.

Powell, J (1993) The Emergence of Bioregionalism in the Murray-Darling Basin, Canberra: ACT, Murray-Darling Basin Commission.

REPSI (Resources Policy Support Initiative) (2001) Mekong Regional Environmental Governance: Perspectives on Opportunities and Challenges, papers from the Mekong Regional Environmental research and dialogue group, Chiang Mai: REPSI.

Rerkasem, K (2003) Uplands land use, in M Khaosa-ard and J Dore (eds), Social Challenges for the Mekong Region, Chiang Mai: Chiang Mai University, pp. 323-46.

Salas M and Xu Jianchu (2003) Moving the periphery to the centre: indigenous people, culture and knowledge in a changing Yunnan, in M Khaosa-ard and J Dore (eds), Social challenges for the Mekong Region, Chiang Mai: Chiang Mai University, pp. 123-45.

SEARIN (Southeast Asia Rivers Network)(2004) The Return of Fish, River Ecology and Local Livelihoods of the Mun River: A Thai Baan (Villagers') Research, Chiang Mai: SEARIN.

Siamwalla, A (2003) 'Globalisation and its governance in historical perspective', in M Khaosa-ard and J Dore (eds), Social Challenges for the Mekong Region, Chiang Mai: Chiang Mai University, pp. 13-44.

Stensholt, B (1997) Developing the Mekong Subregion, Melbourne: Monash Asia Institute.

Sverdrup-Jensen, S (2002) Fisheries in the Lower Mekong Basin: Status and Perspectives, Vientiane: MRG.

Theeravit, K (2003) Relationships within and between the Mekong Region in the context of globalisation, in M Khaosa-ard and J Dore (eds), Social challenges for the Mekong Region, Chiang Mai: Chiang Mai University, pp. 49-80.

Tim, F (2003) Critical Political Ecology, London: Routledge.

Tsing, A (2003) Agrarian allegory and global futures, in P Greenough and A Tsing (eds), Nature in the Global South: Environmental Projects in South and Southeast Asia, Durham, NC: Duke University Press, pp. 124-69.

Vandergeest, P (1996) Property rights in protected areas: obstacles to community involvement as a solution in Thailand, Environmental Conservation, 23, 259-68.

Walker, P (2003) Reconsidering 'regional' political ecologies: toward a political ecology of the rural American West, Progress in Human Geography, 27, 7-25.

Warren, T (1999) A monitoring study to assess the localized impacts created by the Theun-Hinboun Hydro-Scheme on fisheries and fish populations: final report to TheunHinboun Power Company, accessed at International Rivers Network website: www.irn. org. 
246 Philip Hirsch

Witness, G (2002), Deforestation Without Limits: How the Cambodian Government Failed to Tackle the Untouchables, London: Global Witness.

World Commission on Dams (2000) Dams and Development: A New Framework for Decision-making, London: Earthscan. 


\title{
Index
}

\author{
Africa 79-80 \\ agriculture 13, 20, 43-5, 56-75, 92-5, \\ 102-3, 108-24, 128-43, 147-66, \\ 170-83, 189-205, 211; commercial 34, \\ 43-4, 60-1, 62-4, 113-24, 129-31, \\ 147-66, 170-83, 193-5; subsistence 20, \\ 43-4, 66, 71-2, 77-88, 92-5, 102-3, \\ 134, 137, 169-72, 192-3, 211; \\ sustainable $43,63,70$ \\ agrodiversity $61-2,64,66-7,70-4,76-90$, \\ 109-10, 167-8, 182 \\ agroforestry 43, 44, 56, 76-90, 95, 168, \\ $171-81$ \\ aid 1, 26, 39, 42, 52, 140, 195 \\ Amazonia 79 \\ Anderson, Benedict 17 \\ aquaculture $47-8,52$ \\ Asia 2, 5-7, 42, 46, 79, 152, 209-10, 216 \\ Asian Development Bank (ADB) 228, 243 \\ atolls 38-55 \\ Australia 42, 110-11, 140, 234 \\ bananas $61,72,79$ \\ betel nuts 78 \\ biodiversity 4, 56, 86-8, 134, 169 \\ Blaikie, Piers 8, 16, 91, 187-8, 194, 208-9, \\ 220, 232, 234, 239, 243 \\ Boserup, Ester 108, 124 \\ Bougainville 4, 127-46 \\ breadfruit $60,64,78,81,84,85$ \\ Brookfield, Harold 5, 7-8, 13, 16, 27, 33, \\ $51,56,79,91,108-10,124,142,147-8$, \\ $150,151,167-8,186-8,194,205$, \\ 208-9, 211, 214, 220-1, 223-4, 226-7, \\ 232-4, 236, 239-40, 242-3 \\ brookfields $68-9$ \\ bureaucracy $34,41,42$ \\ Cambodia 227 \\ canals 191-3, 203-4 \\ cargo cults 131 \\ cassava 56, 60, 66, 134 \\ cattle 20, 62, 101, 102, 130, 135 \\ Chambers, Robert 12 \\ China 227, 230, 236 \\ Chinese 148, 152, 161 \\ civil society $239-40$ \\ Clarke, Bill 9 \\ climate change 4,40 \\ cocoa 130-4, 137-40 \\ coconuts 78,84 \\ coffee 80, 148 \\ colonialism 27, 57-8, 71, 94, 128-9, 148, \\ 191, 193 \\ commoditization $6,58,60-1,95,120$, \\ $128-9$ \\ communication 43, 59, 129 \\ community $8,39,137-8,143$ \\ conflict 110, 112-13, 116, 119-20, 122, \\ $136-7,138$ \\ conservation $17,27,52$ \\ consumption 49, 72, 129-30, 132, 135 \\ Cook Islands 47 \\ cooperatives 91, 94-5, 132-3, 170 \\ copra 42, 43, 53, 60-1, 72; see also coconuts \\ corruption 32,138 \\ cosmology 22-3 \\ crocodiles 135, 140 \\ Cuba 31, 33 \\ culture 11,44, 50, 88, 117-18, 121, 144, \\ 173 \\ dams 199, 227, 230, 236-8, 241 \\ Dayaks 167, 169, 171-2, 182 \\ decentralization $11,38-9,51,52,95-6$, \\ $168,182-3,240$ \\ deforestation 4, 9, 80, 99, 149, 151-2, 154, \\ $158,162,178,210,213-14$
}


demography see population

dependence 39

development 1-4, 13, 42-3, 49, 50, 52, 88,

142-4, 226; interdependent 233-4, 239; theory $1-3$

disasters see natural hazards

drought 40, 214

durian (Durio zibethinus) 172, 173, 178

ecology: cultural ecology 8-10, 17, 68-70, 76-88; political ecology 9-10, 16-37, 59-60, 67-8, 91-107, 186, 188, 205, 208, 220

economic growth 2, 6, 50, 130-2

economic policy 50, 95-103, 150, 199, 230

ecotourism 48, 61, 72-3

education 41, 49, 131, 137, 143

El Niño 4, 46, 47, 172

employment 41, 51, 52, 57, 59-60, 130-50

empowerment $6,9,12,104$

energy 52, 135

entrepreneurs 130, 131

environmental degradation 2, 46, 134, 151, 208-10, 212, 214, 223, 233

erosion 9, 52, 64, 134, 151, 208-12, 217-20

ethnicity 92, 102-5, 182, 213-14, 222, 229, 238

exchange 80, 117-18, 120

Fiji 7, 47, 56-75

financial crisis, Asian 6

firewood 101, 140

fishing 4, 42, 45-7, 193, 196, 227-8

food see nutrition

food security 43,47

forestry 4, 27, 52, 96-8, 99, 101, 148, 151-2

French Polynesia 47

G8 1

gender 114, 117, 133, 150

ginger 61,72

global warming 4,40

globalisation 3, 5, 10-11, 72, 143, 226

goats 62

Green Revolution 174, 194-7

handicrafts $62-3$

health 50,137

hill tribes 92-5, 102-5, 213-14, 216-18, 238

Himalayas 209, 210

Hmong 92-5, 102-5 households 109-10, 112, 115-24, 131, 156-7

houses 112,135

hunting 79, 134

hydro-power 227, 230-1, 234, 236, 238

Iban 156-7, 161, 163

identity $16-22,92-5$

incomes 46, 49, 115-16, 120, 131, 143, 176

indigenous knowledge see knowledge, traditional

individualism 3, 122, 132-3, 142

Indonesia 16-37, 167-85

intensification 56, 66, 79, 108-10, 137, 138-9, 174-5, 186, 189-90, 194, 196-9, 201, 205, 208, 209, 211-12

irrigation 56, 57, 60, 64, 67-8, 81, 189, $197-8,222$

Japan 42, 52, 129, 234

Java 16-37

Joint Venture Projects 156-9, 161-3

Jolly, Richard 3

Kadavu (Fiji) 56-75

Kalimantan (Indonesia) 167-85

kava (Piper methysticum) 57, 59, 61, 62-4, 71

Kiribati 38-55

Kiritimati (Christmas Island) 41, 44, 48

knowledge, traditional 7, 10, 12, 32, 132

labour 43, 113-22, 123, 124

land: commoditization 133, 161; degradation 17, 73, 209-11; disputes 81, 102-3, 171-2; reform 91-107, 194-5; tenure 43, 45, 68-9, 81, 93, 95-100, 111 , 122, 149, 152-4, 156-7, 172, 176, 192, 222; use 44, 61-2, 66-9, 71-2, 96, 101, $111,134,137,153-4,157,191-3,213$

landesque capital 182, 186, 188-9, 194, 205

Laos 227, 234

Latouche, Serge 4

Latour, Bruno 33

leadership 121, 123, 141-2 ,186, 182

logging see deforestation

Malaysia 147-66, 170

manufacturing 6, 151

marginalisation 102-4, 105-6

markets 42, 43, 44, 47, 80, 129-30, 135, 138

media 24-31

Mekong 186-207, 226-46

Melanesia 8, 76-90, 108-46 
Micronesia 38-55

migration 41, 50, 52, 59-60, 72, 111 , $150-1,159,234$

mining 4, 28-9, 42, 130, 148

MIRAB model 42, 50, 52

modernity 3, 17, 33, 69, 71, 86, 117, 129, 135-6, 138, 141, 144, 172-3, 183

national parks 27

natural hazards $16-37,70,110,172$, 189-90, 214

Nauru 41

neo-liberalism 1, 4, 72

New Britain (Papua New Guinea) 109-24

New Zealand 41, 60

Non Governmental Organizations (NGOs) 26-7, 33, 231-2, 240-1, 243

nutrition 47, 50, 65, 71, 134, 137

nuts $78,80,168$

oil 152

oil palm 108-26, 147-85

Oliver, Douglas 127, 133-4, 141, 145n2

pandanus 62, 72, 78, 81, 85

Papua New Guinea 7, 9-10, 34, 78-90, 108-46

participatory rural appraisal 98-100

peasants 7,132

pigs $23,44,62,66,129$

pineapples $61,72,174$

plantations 4, 26, 57, 60, 111, 147-64, 168-83

politics 17, 25-6, 51, 53, 94

pollution 40, 41, 48, 151

Polynesia 121

population 28, 40, 48, 111-13, 118-19,

136, 138, 209-10

post-development 3

postmodernism 3

poverty $2,38-9,47,53$

rainfall 57, 98, 214

reforestation 210, 213-14

religion 72 , 128, 140-1, 143

remittances $41,42,150$

resource curse 12, 142, 148

rice $92,94-5,97,99,102-3,129,149-50$,

169, 172-5, 180-1, 190-3, 197-201, 222,229

risk 124, 174, 183, 189, 211, 221, 223

rituals $17,24,61,78,121$

Rostow, Walter 2-3, 131

royal authority 23-4, 29 rubber 130, 148-9, 151-2, 169, 172-81

Sabah (Malaysia) 152

sago 78, 81, 85, 139

salinity 189-90, 192-3, 196-8, 201-2

Sarawak (Malaysia) 147-66

scale 11, 12, 16, 42, 183, 187-8, 197, 199

seaweed 47

sedimentation 151, 215-16, 219

social change 71, 120-3, 135-6, 140-4

social organization $11,12,39,46,70-1,93$, 102-4, 110, 114-22

socialism 91, 194-204, 226

soils 40, 44

soil erosion see erosion

Solomon Islands 77-8, 80-1, 86, 138

sport 136, 144

state $91-107$

subsistence see agriculture, subsistence

subsistence affluence 39, 88

sustainable livelihoods 49-52, 163

sweet potatoes 60,129

swidden 56, 79-80, 94-5, 97, 213, 229

taro 56, 57, 60-8, 71-2, 79, 129

technology 39, 46, 110, 137, 194

Thailand 208-25, 237, 240

Tikopia (Solomon Islands) 77

tourism 28-9, 41, 48-9, 52, 59, 236

trade 6, 128-9

tradition 17, 70, 123, 141, 142-3, 178-9, 181, 183

transmigration 27, 169, 170

transport 44, 49, 59, 129-30, 136, 138, 140 , 148, 169, 234

Tuvalu 39, 52

unemployment 112

United Kingdom 41

United Nations 1, 2, 7

urbanization 38-42, 50-1

vanilla 61,140

Vietnam 33, 87, 91-107, 186-207, 234, 238, 240, 241

violence see conflict

volcanoes 16-37

water 9, 40-1, 52, 59, 186-205, 214-17,

227; see also irrigation

World Bank 1, 2, 38, 201-2

World Trade Organization 1

yams $56,60,67,78$ 
eBooks - at www.eBookstore.tandf.co.uk

\section{A library at your fingertips!}

eBooks are electronic versions of printed books. You can store them on your PC/laptop or browse them online.

They have advantages for anyone needing rapid access to a wide variety of published, copyright information.

eBooks can help your research by enabling you to bookmark chapters, annotate text and use instant searches to find specific words or phrases. Several eBook files would fit on even a small laptop or PDA.

NEW: Save money by eSubscribing: cheap, online access to any eBook for as long as you need it.

\section{Annual subscription packages}

We now offer special low-cost bulk subscriptions to packages of eBooks in certain subject areas. These are available to libraries or to individuals.

For more information please contact webmaster.ebooks@tandf.co.uk

We're continually developing the eBook concept, so keep up to date by visiting the website. 